UNIVERSIDADE DE BRASÍLIA

FACULDADE DE AGRONOMIA E MEDICINA VETERINÁRIA

PROGRAMA DE PÓS-GRADUAÇÃO EM AGRONOMIA

DESEMPENHO AGRONÔMICO, DIVERSIDADE GENÉTICA E AVALIAÇÃO DE DOENÇAS EM PROGÊNIES DE MARACUJAZEIROAZEDO

ANA PAULA GOMES DE CASTRO

TESE DE DOUTORADO EM AGRONOMIA

BRASÍLIA/DF

MAIO/2015 


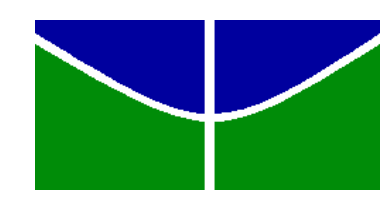

UNIVERSIDADE DE BRASÍLIA

FACULDADE DE AGRONOMIA E MEDICINA VETERINÁRIA

PROGRAMA DE PÓS-GRADUAÇÃO EM AGRONOMIA

DESEMPENHO AGRONÔMICO, DIVERSIDADE GENÉTICA E AVALIAÇÃO DE DOENÇAS EM PROGÊNIES DE MARACUJAZEIROAZEDO

ANA PAULA GOMES DE CASTRO

ORIENTADOR: JOSÉ RICARDO PEIXOTO

CO-ORIENTADOR: FÁBIO GELAPE FALEIRO

TESE DE DOUTORADO EM AGRONOMIA

PUBLICAÇÃO: 033D/2015

BRASÍLIA/DF

MAIO/2015 
UNIVERSIDADE DE BRASÍLIA

FACULDADE DE AGRONOMIA E MEDICINA VETERINÁRIA

PROGRAMA DE PÓS-GRADUAÇÃO EM AGRONOMIA

\section{DESEMPENHO AGRONÔMICO, DIVERSIDADE GENÉTICA E AVALIAÇÃO DE DOENÇAS EM PROGÊNIES DE MARACUJAZEIRO- AZEDO}

ANA PAULA GOMES DE CASTRO

TESE DE DOUTORADO SUBMETIDA À FACULDADE DE AGRONOMIA E MEDICINA VETERINÁRIA DA UNIVERSIDADE DE BRASÍLIA, COMO PARTE DOS REQUISITOS NECESSÁRIOS À OBTENÇÃO DO GRAU DE DOUTOR EM AGRONOMIA NA ÁREA DE CONCENTRAÇÃO DE PRODUÇÃO VEGETAL.

\section{APROVADO POR:}

Eng. Agrônomo, José Ricardo Peixoto, Doutor (Universidade de Brasília - FAV) (Orientador) CPF: 354.356.236-34. E-mail: peixoto@unb.br

Eng. Agrônomo, Carlos Hidemi Uesugi, Doutor (Universidade de Brasília - IB) (Examinador Externo) CPF: 057615731-72. E-mail: uesugich@unb.br

Eng. Agrônomo, Márcio de Carvalho Pires, Doutor (PNPD-CAPES) (Examinador Externo) CPF: 844.256.601-53. E-mail: mcpires@unb.br

Eng. Agrônoma, Nara Oliveira Silva Souza, Doutora, (Universidade de Brasília - FAV) (Examinador Interno) CPF: 033300726-36. E-mail: narasouza@unb.br

Eng. Agrônoma, Michelle Souza Vilela, Doutora (Universidade de Brasília - FAV) (Examinador Externo) CPF: 919623401-63 E-mail: michellevilelaunb@gmail.com 


\section{FICHA CATALOGRÁFICA}

\section{Castro, Ana Paula Gomes}

Desempenho agronômico, diversidade genética e avaliação de doenças em progênies de maracujazeiro-azedo. Ana Castro; Orientação: José Ricardo Peixoto.Co-orientação: Fábio Gelape Faleiro. Brasília, 2015.

$204 p$.

Tese de Doutorado (Dr) - Universidade de Brasília / Faculdade de Agronomia e Medicina Veterinária, 2015.

1. Maracujá. 2. Desempenho agronômico. 3. Reação a doenças. 4. Diverdidade genética.

CDU

\section{REFERÊNCIA BIBLIOGRÁFICA}

CASTRO, A.P.G. Desempenho agronômico, diversidade genética e avaliação de doenças em progênies de maracujazeiro-azedo. Faculdade de Agronomia e Medicina Veterinária, Universidade de Brasília, 2015; 204p.

Tese de Doutorado.

\section{CESSÃO DE DIREITOS}

NOME DA AUTORA: Ana Paula Gomes de Castro

TÍTULO DA TESE DE DOUTORADO: Desempenho agronômico, diversidade genética e avaliação de doenças em progênies de maracujazeiro-azedo.

GRAU: Doutor. ANO: 2015

É concedida à Universidade de Brasília permissão para reproduzir cópias desta tese de doutorado e para emprestar ou vender tais cópias somente para propósitos acadêmicos e científicos. O autor reserva os outros direitos de publicação e nenhuma parte desta tese de doutorado pode ser reproduzida sem a autorização por escrito da autora.

Ana Paula Gomes de Castro

CPF: 707251101-63

Endereço: AOS 01 Bloco "F" Apt 413 Octogonal

Tel: 8157-1703Ｅmail: anapgcastro@yahoo.com.br 
À minha maior ESTRELA, Dalva Gomes dos Santos (in memorian), e à minha ESTRELA guia Dalva Gomes de Castro.

\section{Dedico}

Ao meu pai,

Osvaldo Miranda de Castro,

por ser minha FORÇA!

\section{Ofereço}




\section{AGRADEÇO}

A Deus, presença viva em minha vida, que me permite realizar TODOS os meus sonhos, por mais difíceis que possam parecer ...ELE que iluminou o meu caminho e me deu forças para seguir em frente em cada momento da minha árdua jornada.

À minha amada AVÓ, minha maior ESTRELA, que partiu no decorrer dessa caminhada com a certeza de que faltava pouco para mais um sonho a ser realizado em minha vida.

À minha MÃE, minha ESTRELA guia, por seu infinito amor, dedicação, carinho, ajuda e por ter sempre acreditado em mim e nos meus maiores sonhos.....

Ao meu PAI, minha FORÇA, pelos seus ensinamentos na simplicidade de ser e de viver.

Ao tio Binho, muitas vezes pai, por ser um exemplo de superação a ser seguido.

À tia Elzira por estar sempre orando e torcendo por mim.

Ao professor José Ricardo Peixoto, pela orientação, motivação, dedicação, disponibilidade, ensinamentos e em especial pela sua infinita paciência.

Ao Dr. Fábio Faleiro pelo seu exemplo de profissionalismo, pela oportunidade e ensinamentos. Meus sinceros agradecimentos.

Aos funcionários da Fazenda Água Limpa, Queen, Mirão, Luiz, Omero, pelo apoio nos experimentos de campo.

Aos estagiários que tanto contribuíram para a realização do trabalho em especial, Moníse, Daiane, Adrielly, Jaqueline... e tantos outros.

Aos amigos que fiz... Paula Andréa, Angélica e Adriana com quem compartilhei um pouquinho de cada fase vivida no decorrer desses quatro anos.

À Universidade de Brasília pela oportunidade e à Embrapa Cerrados pela realização do trabalho.

À doce amiga Susan pelo seu imenso carinho por mim.

À amiga Kênia, tão presente desde o mestrado, e agora no doutorado não foi diferente... agradeço por todas as ajudas e pelas várias risadas juntas.

Como não agradecer a cada um dos meus superiores do Exército Brasileiro, afinal, se eles não tivessem comprado a ideia, eu não teria chegado até aqui. Desde o Gen Gonçalves, Cel Marco Aurélio, Gen Lauro que teve a sensibilidade de perceber o quanto era importante para mim a realização desse sonho, Cel Risse, Cel Morais e outros que passaram pela DPIMA/SMA. 
Falando de superiores, como não mencionar o TC Sandro que sempre perguntava "e a defesa, quando será??? março, abril ou maio." Confesso que dava um frio na barriga, mas ao mesmo tempo era um incentivo, afinal, ele é um grande exemplo de humildade, inteligência e profissionalismo... da mesma forma como não falar do Maj Fraga, sempre tão positivo" - Ana, essa é a melhor fase da vida, você nunca vai esquecer de cada um dos minutos dedicado ao seu trabalho".

E à amiga/irmã Isabel com quem dividi um pouquinho desses últimos anos, sempre com suas orações que faz tanta diferença. Da mesma forma, como não lembrar das tantas vezes que ouvi minha sempre amiga Valéria Dutra... você precisa terminar logo esse doutorado... precisamos fazer outras coisas... estou sem companhia para sair... E a pequena Elisângela que espera com paciência o nosso encontro para tantas comemorações (natal, ano novo, carnaval, páscoa, aniversários) atrasados...

E Moniquinha, nossa tão longe e tão presente... saudade sem fim ...da época da Rural que não volta mais!!!

Agradeço à Sabrina por todas as ajudas e à Zélia pela amizade.

Agradeço de maneira especial ao Gustavo por estar presente nesta fase da minha vida.

Agradeço ao amigo Rodrigo Mendes Martins (MM) por todas as ajudas.

À banca pela disponibilidade de tempo para o aprimoramento do trabalho.

Aos professores da Agronomia pelos ensinamentos compartilhados.

A todos que, de certa forma, contribuíram para essa tão sonhada e esperada conquista!!!!

Agora sim, vira-se a página da vida!!! 


\section{RESUMO}

O Brasil é o maior produtor mundial de maracujá. A produção brasileira possui dois destinos: a indústria e o consumo in natura. A cultura é de grande importância econômica e social, devido à geração de alimentos e empregos, mas apresenta problemas agronômicos que afeta 0 ciclo produtivo, reduzindo a qualidade e a produtividade dos frutos. As doenças são os principais problemas que acometem a cultura, podendo ocorrer tanto na parte aérea das plantas quanto nas raízes, ocasionando a morte das plantas. O uso de cultivares resistentes e outras técnicas são as medidas mais eficazes, econômicas e ecológicas de controle de doenças. O trabalho buscou contribuir para a seleção de progênies de maracujazeiro-azedo com resistência à virose do endurecimento dos frutos, bacteriose e aos fungos: antracnose, septoriose e cladosporiose avaliados em casa de vegetação e em condições de campo, por meio de índices de severidade e incidência. As plantas mais resistentes às doenças são promissoras e serão utilizadas em pesquisas posteriores dentro do programa de melhoramento genético desenvolvido pela UnB em parceria com a Embrapa Cerrados. A avaliação das progênies de maracujazeiro-azedo às doenças fúngicas mostrou baixa produtividade e alta suscetibilidade à septoriose, antracnose e cladosporiose, em condições de campo. As avaliações das progênies de maracujazeiro-azedo à bacteriose e virose mostraram que a maioria das progênies é medianamente suscetível a essas doenças. Com a caracterização molecular de progênies de maracujazeiro com base nas avaliações agronômicas de produtividade e tolerância às doenças, as progênies comportaram-se de maneira bem distinta, não havendo tendência de agrupamento das progênies quanto à produtividade e resistência à septoriose, antracnose e virose, o que evidencia diferentes origens genéticas para os diferentes genes envolvidos nessas características. Para a verrugose e bacteriose, houve certa tendência de agrupamento das plantas mais resistentes. Foi verificada alta variabilidade genética evidenciando a variabilidade fenotípica dessas progênies quanto à produtividade e resistência às doenças. Sendo assim, é necessário que os programas de melhoramento genético tenham continuidade, visto que a cultura é de grande importância econômica e social para o país contribuindo de maneira significativa na geração de alimentos e empregos.

Palavras-chave: maracujá, melhoramento genético, resistência a doenças. 


\begin{abstract}
Brazil is the largest producer of passion fruit. Brazilian production has two destinations: the industry and fresh consumption. The culture has great economic and social importance, due to the generation of food and jobs, but offers agronomic problems affecting the production cycle, reducing the quality and productivity of the crops. Diseases are the main problems that affect the culture and can occur both in the shoot as the roots, causing the death of plants. The use of resistant cultivars and other techniques are the most effective, economic and ecological disease control. The study sought to contribute to the selection of passion fruit progenies virus resistance hardening of the fruit, bacteriose and fungi: anthracnose, septoria and cladosporiose evaluated in greenhouse and field conditions by severity indices and incidence. Plants more resistant to disease are promising and will be used in further research into the breeding program developed by UNB in partnership with Embrapa Cerrado. The evaluation of sour passion fruit progenies to fungal diseases showed low productivity and high susceptibility to septoria, anthracnose and cladosporiose in field conditions. Evaluations of progenies of passion fruit to bacteriose and virus showed that most of the progenies is moderately susceptible to these diseases. With the molecular characterization of passion fruit progenies based on agronomic evaluations of productivity and tolerance to diseases, the progenies behaved very differently, with no clustering tendency of progenies for productivity and resistance to septoria, anthracnose and virus, showing different genetic origins to the different genes involved in these characteristics. For scab and bacteriose, there was a tendency of grouping of more resistant plants. It was observed high genetic variability highlighting the phenotypic variability of these progenies for productivity and resistance to disease. Therefore, it is necessary that breeding programs have continuity, as the culture has great economic and social importance for the country contributing significantly in the generation of food and jobs.
\end{abstract}

Keywords: passion fruit, genetic improvement, disease resistance. 


\section{LISTA DE ILUSTRAÇÕES}

Figura 1 - Sintomas causados por X. axonopodis pv. passifloraenas folhas de maracujá-azedo.........27

Figura 2 - Sintomas iniciais da mancha bacteriana do maracujazeiro................................................27

Figura 3 - Sintomas sistêmicos induzidos pelo CABMV em maracujazeiro-amarelo...........................30

Figura 4 - Sintomas sistêmicos do CABMV em Passiflora nitida .........................................................30

Figura 5 - Ciclo de vida do Colletotrichum gloeosporioides ..................................................................34

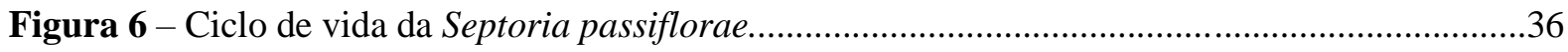

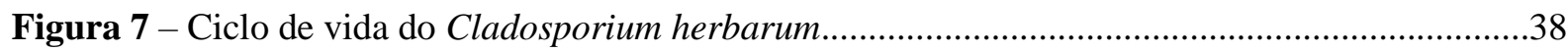

Figura 8 - Escala de notas em plantas de maracujá-azedo inoculadas com X. axonopodis pv.

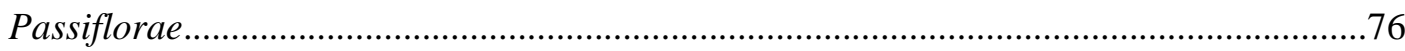

Figura 9 - Matriz de distâncias genéticas calculadas utilizando-se cinquenta e oito marcadores

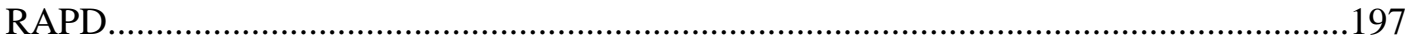

Figura 10 - Gráfico de dispersão quanto à produtividade das dezoito progênies................................199 


\section{LISTA DE TABELAS}

\section{CAPÍTULO 1}

Tabela 1 - Progênies cultivadas em pomares comerciais no município de Araguari/MG utilizadas na seleção massal.

Tabela 2 - Procedência de onze progênies de maracujazeiro-azedo avaliadas no Distrito Federal, Fazenda Água Limpa (FAL) - UnB, 2012 e 2013.

Tabela 3 - Procedência de catorze progênies de maracujazeiro-azedo avaliadas no Distrito Federal, Fazenda Água Limpa (FAL) - UnB, 2012 e 2013. .73

Tabela 4 - Procedência de onze progênies de maracujazeiro-azedo avaliadas no Distrito Federal, Fazenda Água Limpa (FAL) - UnB, 2012 e 2013.

Tabela 5 - Procedência de sete progênies de maracujazeiro-azedo avaliadas no Distrito Federal, Fazenda Água Limpa (FAL) - UnB, 2012 e 2013. .75

Tabela 6 - Procedência de nove progênies de maracujazeiro-azedo avaliadas no Distrito Federal, Fazenda Água Limpa (FAL) - UnB, 2012 e 2013. .77

Tabela 7 - Classificação das plantas inoculadas com Xanthomonas axonopodis pv. passiflorae, em função da escala de notas.

Tabela 8 - Ensaio 01 - Média de severidade e grau de resistência de bacteriose em vinte e quatro progênies de maracujazeiro-azedo, sob condições de casa de vegetação. Estação Biológica - UnB 2012 . .78

Tabela 9 - Ensaio 02 - Média de severidade e grau de resistência de bacteriose em vinte e quatro progênies de maracujazeiro-azedo, sob condições de casa de vegetação. Estação Biológica - UnB 2012 .

Tabela 10 - Ensaio 03 - Média de severidade e grau de resistência de bacteriose em vinte e quatro progênies de maracujazeiro-azedo, sob condições de casa de vegetação. Estação Biológica - UnB 2012 .80

Tabela 11 - Ensaio 04 - Média de severidade e grau de resistência de bacteriose em vinte e quatro progênies de maracujazeiro-azedo, sob condições de casa de vegetação. Estação Biológica - UnB 2012.

Tabela 12 - Ensaio 05 - Média de severidade e grau de resistência de bacteriose em vinte e quatro progênies de maracujazeiro-azedo, sob condições de casa de vegetação. Estação Biológica - UnB 2012.

Tabela 13 - Estimativas das variâncias fenotípica (Vf), genotípica (Vg), ambiental (Ve), herdabilidade sentido amplo $\left(\mathrm{h}^{2}\right)$, coeficiente de variação genético $(\mathrm{CVg})$ e razão entre coeficiente e variação genético e ambiental $(\mathrm{CVg} / \mathrm{CVe})$, utilizando-se dados de cinco avaliações de cento e vinte progênies de maracujazeiro-azedo em casa de vegetação, descritos para três variáveis resposta. Estação Biológica - UnB 2012. 


\section{CAPÍtULO 2}

Tabela 14 - Progênies cultivadas em pomares comerciais no município de Araguari/MG, utilizadas na seleção massal.

Tabela 15 - Procedência de progênies de maracujazeiro-azedo avaliadas no Distrito Federal, Fazenda Água Limpa (FAL) - UnB, 2012 e 2013. . .98

Tabela 16 - Classificação das plantas inoculadas com Septoria Paseflorae, em função da escala de notas médias.

Tabela 17 - Média de severidade e grau de resistência de septoriose em vinte e quatro progênies de maracujazeiro-azedo, sob condições de casa de vegetação. Estação Biológica - UnB 2012. 101

Tabela 18 - Estimativas das variâncias fenotípica (Vf), genotípica (Vg), ambiental (Ve), herdabilidade sentido amplo $\left(\mathrm{ha}^{2}\right)$, coeficiente de variação genético $(\mathrm{CVg})$ e razão entre coeficiente e variação genético e ambiental $(\mathrm{CVg} / \mathrm{CVe})$, utilizando-se dados de quatro avaliações de vinte e quatro progênies de maracujazeiro-azedo em casa de vegetação, descritos para três variáveis resposta. Estação Biológica - UnB 2012 . 102

\section{CAPÍTULO 3}

Tabela 19 - Dados meteorológicos do período do experimento em campo, na Fazenda Água Limpa (FAL) : Out-2011 a Ago-2013.

Tabela 20 - Progênies cultivadas em pomares comerciais no município de Araguari/MG, utilizadas na seleção massal.

Tabela 21 - Procedência de progênies de maracujazeiro-azedo avaliadas no Distrito Federal, Fazenda Água Limpa (FAL) - UnB, 2012 e 2013.

Tabela 22 - Classificação dos frutos de acordo com o seu diâmetro equatorial (mm), utilizada no experimento de avaliação de quarenta e oito progênies cultivadas na FAL - UnB, 2012 e 2013 .115

Tabela 23 - Número total de frutos (frutos/ha), produtividade ( $\mathrm{Kg} / \mathrm{ha})$ e massa média ( $\mathrm{g} /$ frutos) por classificação de frutos quanto ao diâmetro equatorial.

Tabela 24 - Estimativas de herdabilidade sentido amplo $\left(\right.$ ha $\left.^{2}\right)$, coeficiente de variação genético $(\mathrm{CVg})$ e razão entre coeficiente e variação genético e ambiental ( $\mathrm{CVg} / \mathrm{CVe})$, utilizando-se dados de trinta e duas colheitas de quarenta e oito progênies de maracujazeiro-azedo em campo no Distrito Federal, descritos para doze variáveis resposta. Brasília, 2012/2013.

\section{CAPÍTULO 4}

Tabela 25 - Progênies cultivadas em pomares comerciais no município de Araguari/MG, utilizadas na seleção massal. .136

Tabela 26 - Procedência de progênies de maracujazeiro-azedo avaliadas no Distrito Federal, Fazenda Água Limpa (FAL) - UnB, 2012 e 2013. 
Tabela 27 - Notas e sintomas visuais utilizados para análise dos frutos de quarenta e duas progênies de maracujazeiro-azedo, proposta por Junqueira et al., (2003).

Tabela 28 - Notas e sintomas visuais utilizados para análise dos frutos de quarenta e duas progênies de maracujazeiro-azedo, proposta por JUNQUEIRAet al., (2003) e adaptado por SOUSA (2005)....139 Tabela 29 - Incidência de septoriose nas quatro diferentes épocas em quarenta e duas progênies de maracujazeiro-azedo. 142

Tabela 30 - Severidade de septoriose nas quatro diferentes épocas em quarenta e duas progênies de maracujazeiro-azedo.

Tabela 31 - Incidência de antracnose nas quatro diferentes épocas em quarenta e duas progênies de maracujazeiro-azedo. 148

Tabela 32 - Severidade de antracnose nas quatro diferentes épocas em quarenta e duas progênies de maracujazeiro-azedo.

Tabela 33 - Incidência de verrugose nas quatro diferentes épocas em quarenta e duas progênies de maracujazeiro-azedo.

Tabela 34 - Severidade de verrugose nas quatro diferentes épocas em quarenta e duas progênies de maracujazeiro-azedo.

Tabela 35 - Efeito da septoriose, antracnose e verrugose em progênies de maracujazeiro-azedo a partir das médias da área abaixo da curva de progresso da doença (AACPD) em condições de campo .151

Tabela 36 - Estimativas de herdabilidade sentido amplo $\left(\mathrm{ha}^{2}\right)$, coeficiente de variação genético $(\mathrm{CVg})$ e razão entre coeficiente e variação genético e ambiental ( $\mathrm{CVg} / \mathrm{CVe})$, utilizando-se dados de quarenta e duas progênies de maracujazeiro-azedo.

\section{CAPÍTULO 5}

Tabela 37 - Progênies cultivadas em pomares comerciais no município de Araguari/MG, utilizadas na seleção massal.

Tabela 38 - Procedência de progênies de maracujazeiro-azedo avaliadas no Distrito Federal, Fazenda Água Limpa (FAL) - UnB, 2012 e 2013.

Tabela 39 - Notas e sintomas visuais utilizados para análise dos frutos de quarenta e oito progênies de maracujazeiro-azedo, proposta por JUNQUEIRA et al., (2003).

Tabela 40 - Notas e sintomas visuais utilizados para análise das folhas 167

Tabela 41 - Incidência de virose nas quatro diferentes épocas em quarenta e duas progênies de maracujazeiro-azedo.

Tabela 42 - Severidade de virose nas quatro diferentes épocas em quarenta e duas progênies de maracujazeiro-azedo.

Tabela 43 - Incidência de bacteriose nas quatro diferentes épocas em quarenta e duas progênies de maracujazeiro-azedo. 
Tabela 44 - Severidade de bacteriose nas quatro diferentes épocas em quarenta e duas progênies de maracujazeiro-azedo. 176

Tabela 45 - Efeito da bacteriose e virose em progênies de maracujazeiro-azedo a partir das médias da área abaixo da curva de progresso da doença (AACPD) em condições de campo. .178

Tabela 46 - Estimativas de herdabilidade sentido amplo $\left(\mathrm{ha}^{2}\right)$, coeficiente de variação genético $(\mathrm{CVg})$ e razão entre coeficiente e variação genético e ambiental ( $\mathrm{CVg} / \mathrm{CVe})$, utilizando-se dados de quarenta e oito progênies de maracujazeiro-azedo.

\section{CAPÍTULO 6}

Tabela 47 - Nome e origem das progênies analisadas no trabalho.

Tabela 48 - Primers utilizados para obtenção dos marcadores RAPD e respectivos número de bandas polimórficas e monomórficas

Tabela 49 - Matriz de dissimilaridade genética entre dezoito progênies de maracujá-azedo 196 


\section{SUMÁRIO}

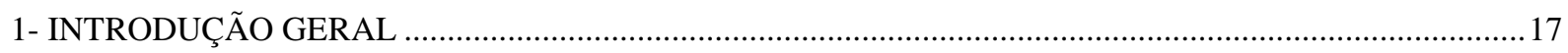

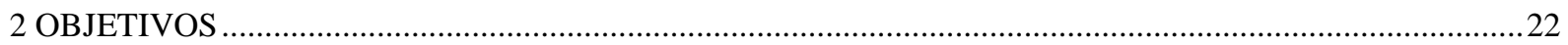

2.1 OBJETIVO GERAL

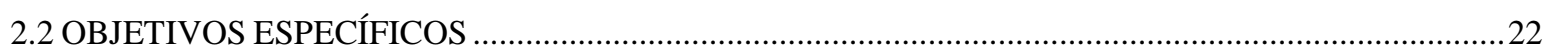

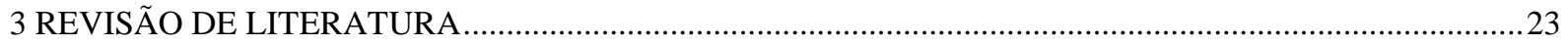

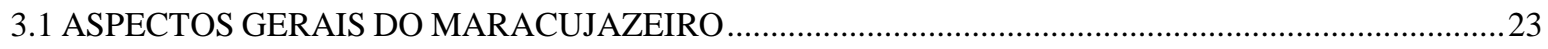

3.2 A BACTERIOSE CAUSADA POR XANTHOMONAS AXONOPODIS PV. PASSIFLORAE ..................25

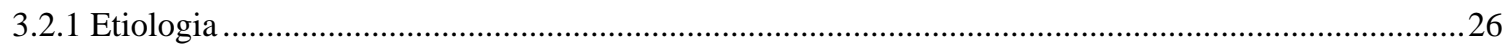

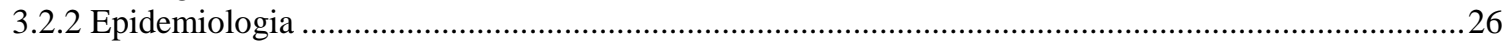

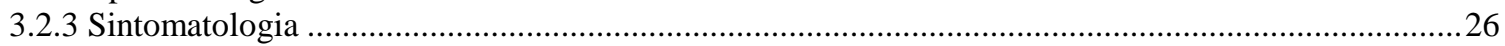

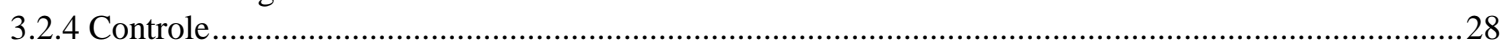

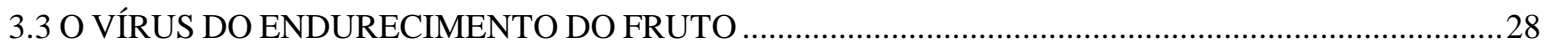

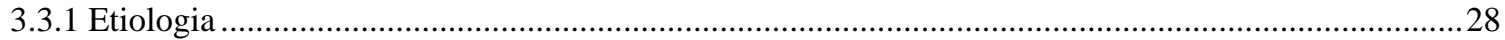

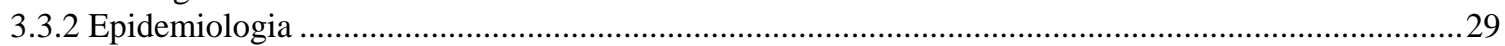

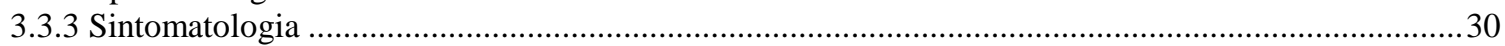

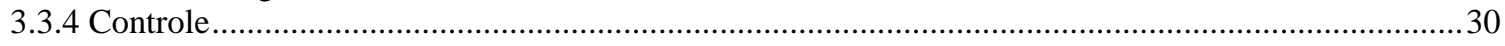

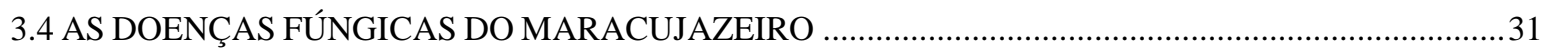

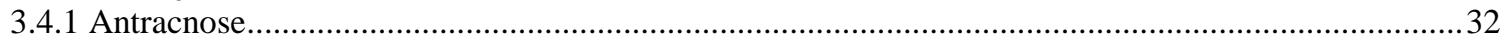

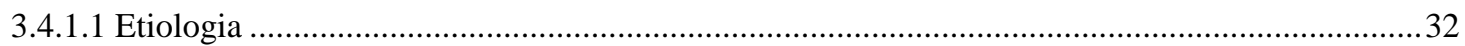

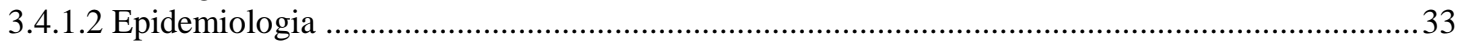

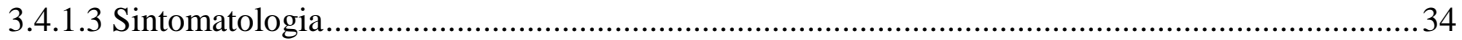

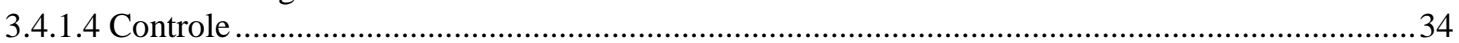

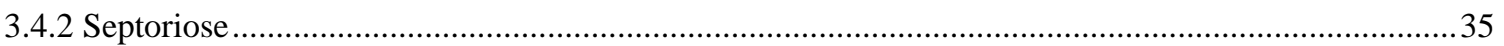

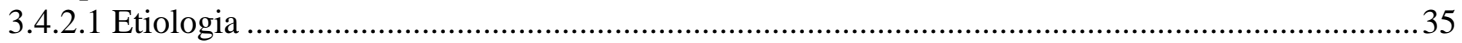

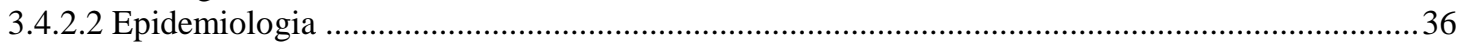

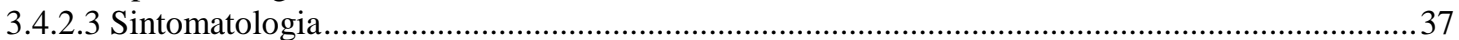

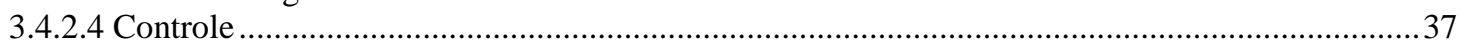

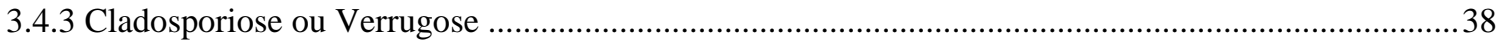

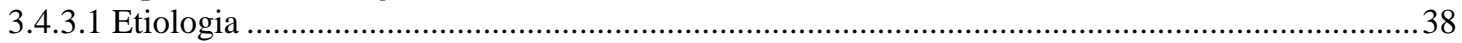

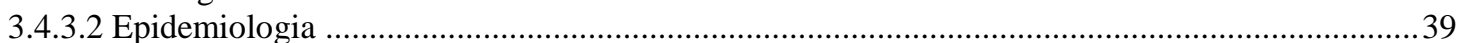

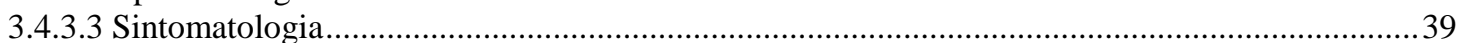

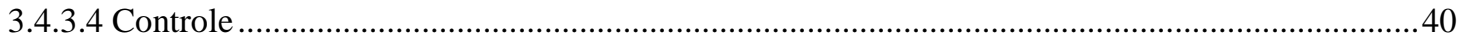

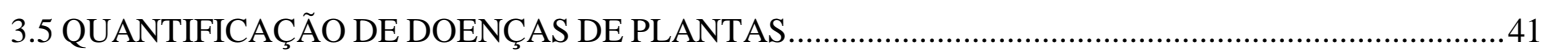

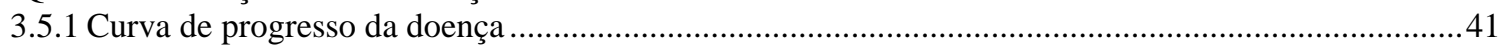

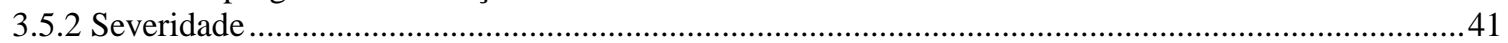

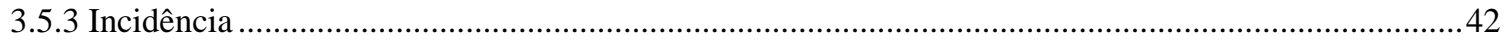

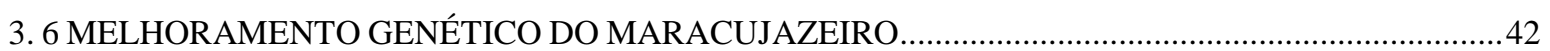

3.7 MELHORAMENTO VISANDO À RESISTÊNCIA ÀS DOENÇAS DO MARACUJAZEIRO .................45

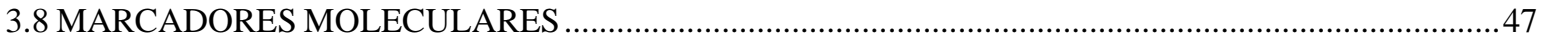

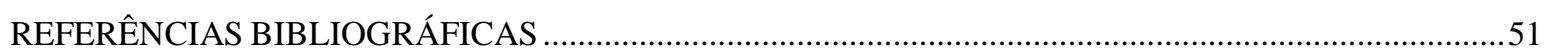

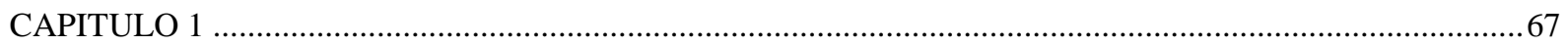

RESISTÊNCIA DE PROGÊNIES DE MARACUJAZEIRO-AZEDO À BACTERIOSE EM CASA DE

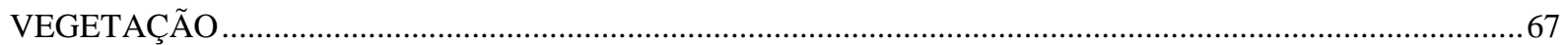

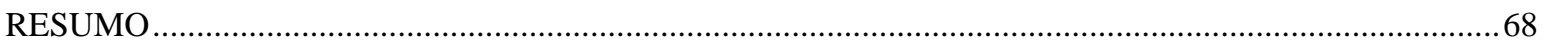

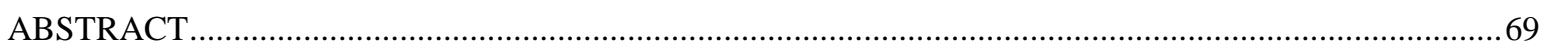

1 - INTRODUÇÃO 


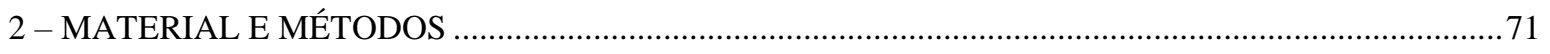

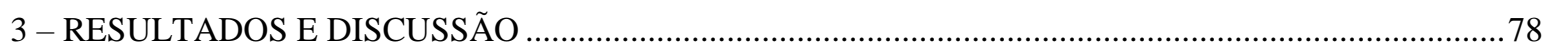

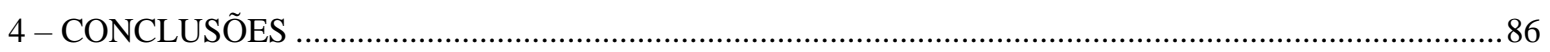

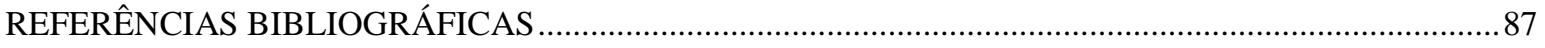

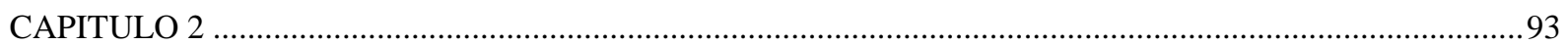

RESISTÊNCIA DE PROGÊNIES DE MARACUJAZEIRO-AZEDO À SEPTORIOSE, EM CONDIÇÕES DE

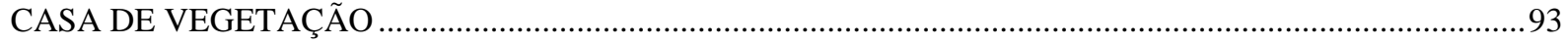

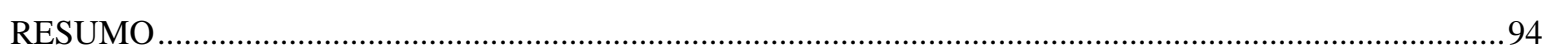

ABSTRACT

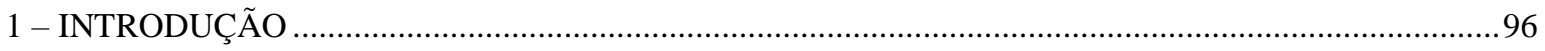

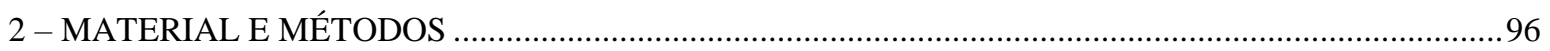

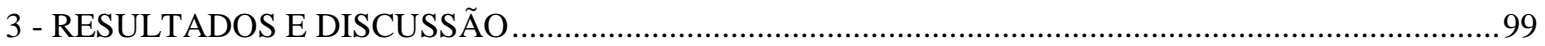

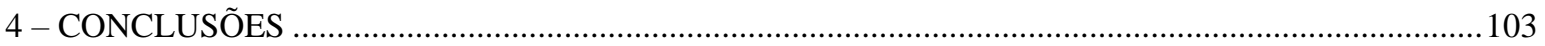

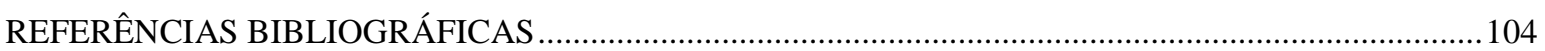

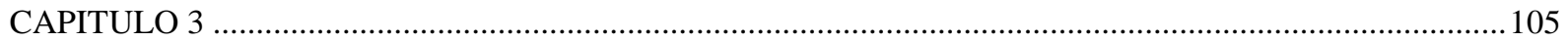

DESEMPENHO PRODUTIVO DE QUARENTA E OITO PROGÊNIES DE MARACUJAZEIRO-AZEDO NO

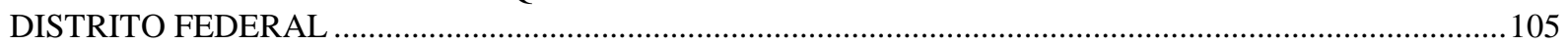

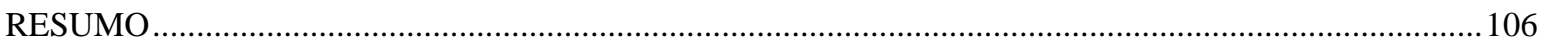

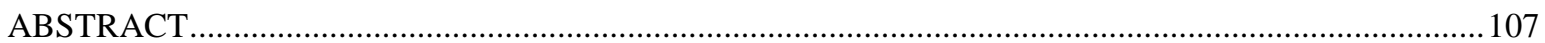

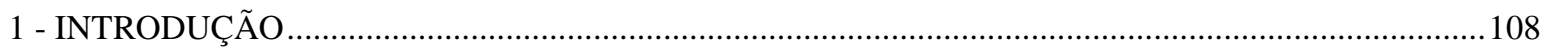

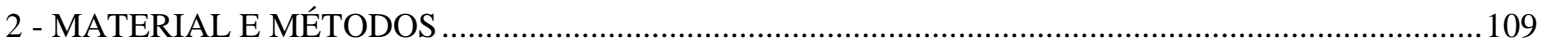

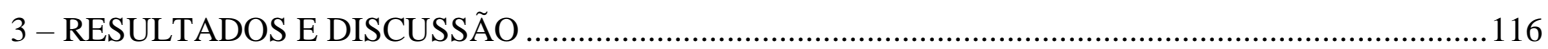

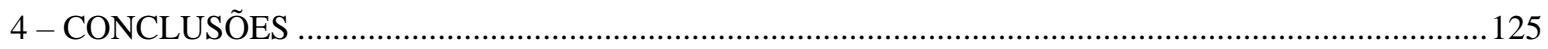

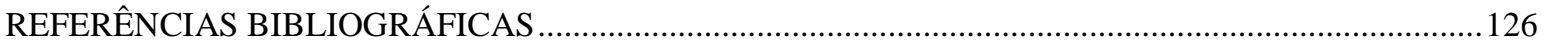

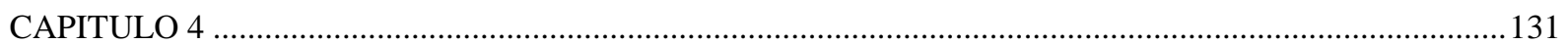

RESISTÊNCIA DE PROGÊNIES DE MARACUJAZEIRO-AZEDO À SEPTORIOSE, ANTRACNOSE E

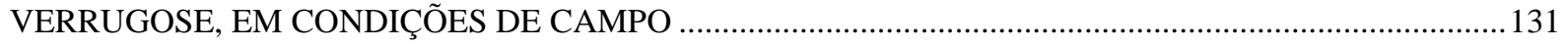

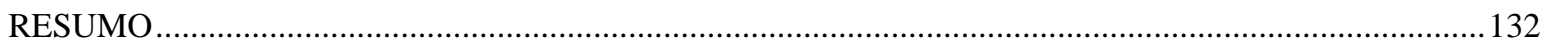

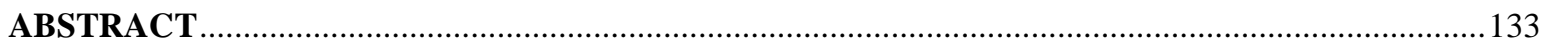

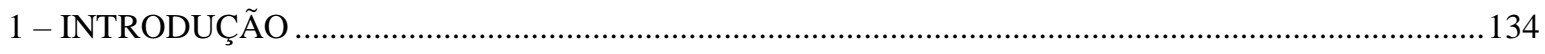

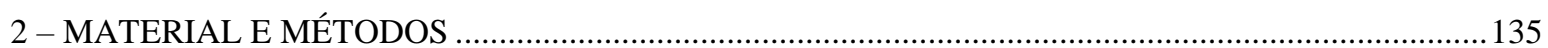

Tabela 28 - Notas e sintomas visuais utilizadas para análise dos frutos de quarenta e duas progênies de maracujazeiro-azedo, proposta por JUNQUEIRA et al., (2003) e adaptado por SOUSA, (2005). ....................139

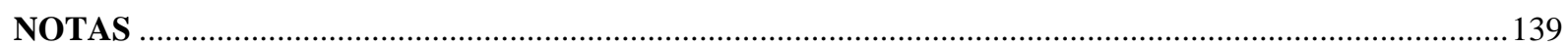

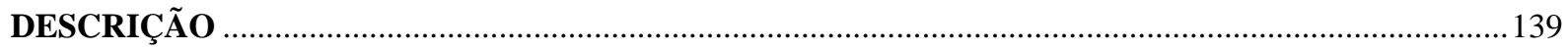

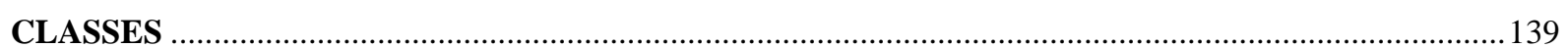

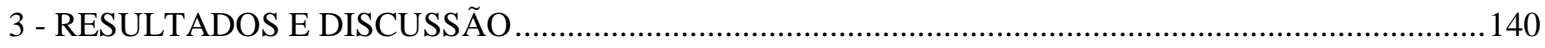

A - SEPTORIOSE 
B - ANTRACNOSE

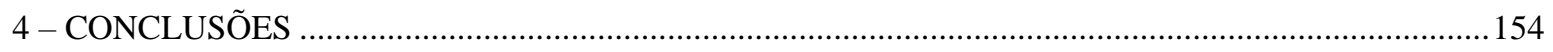

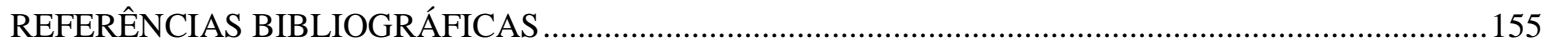

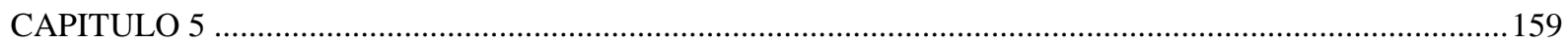

RESISTÊNCIA DE PROGÊNIES DE MARACUJAZEIRO-AZEDO À VIROSE E À BACTERIOSE, EM

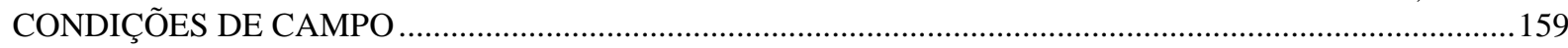

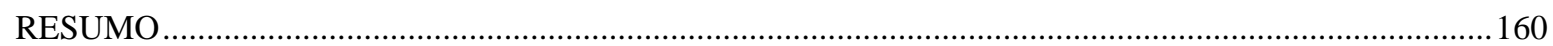

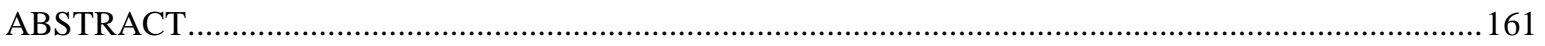

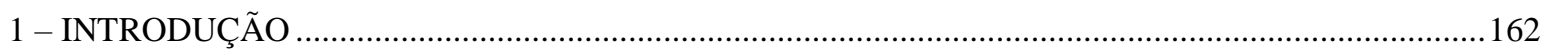

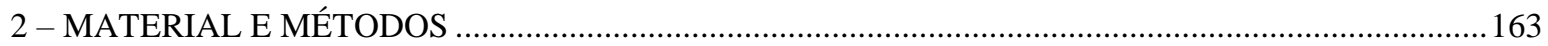

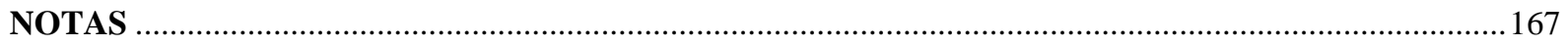

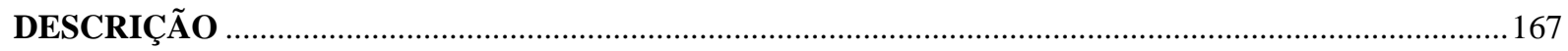

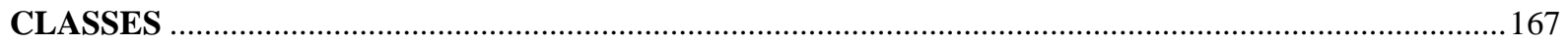

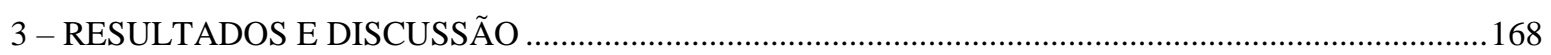

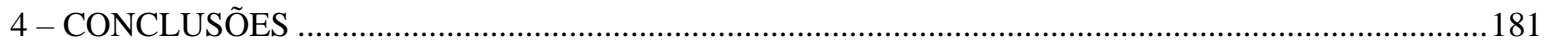

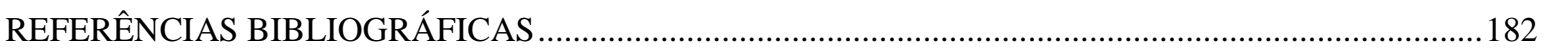

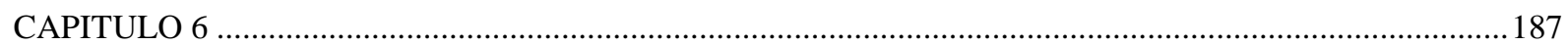

CARACTERIZAÇÃO MOLECULAR DE PROGÊNIES DE MARACUJAZEIRO-AZEDO COM DIFERENTES NIVEIS DE PRODUTIVIDADE E RESISTÊNCIA A DOENÇAS ..........................................187

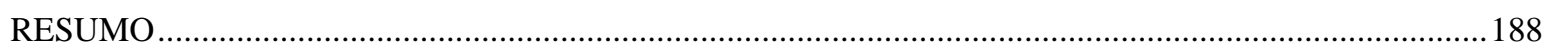

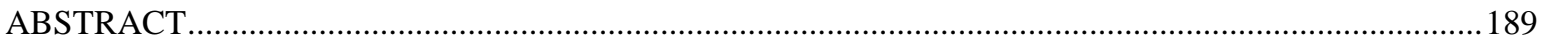

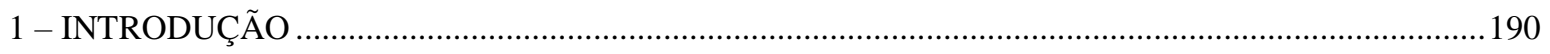

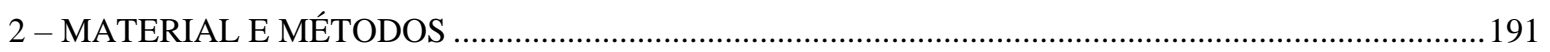

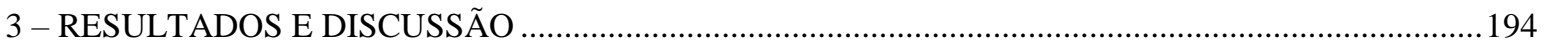

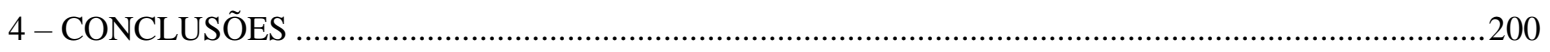

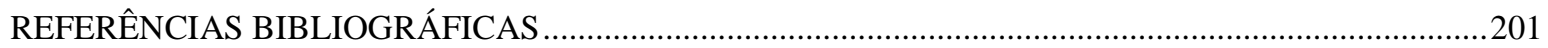

ANEXOS 


\section{1- INTRODUÇÃO GERAL}

A palavra maracujá é uma denominação indígena, de origem tupi que significa "alimento em forma de cuia". O maracujazeiro também é conhecido como flor-da-paixão, nome popular pouco usual no Brasil que tem origem na correlação da morfologia da flor com os símbolos da Paixão de Cristo (SOUZA \& MELETTI, 1997). Tal correlação é explicada por Frei Vicente (HOEHNE, 1937) referindo-se, inicialmente, aos três estiletes/estigmas que representam a Santíssima Trindade e aos três cravos utilizados na crucificação de Jesus Cristo; os cinco filetes/estames representam as cinco chagas e a corona/verticilos, a coroa de espinhos de Jesus Cristo. As folhas, em forma de lança, segundo Frei Vicente, também estão relacionadas aos símbolos da Paixão de Cristo.

O maracujazeiro é uma planta tropical, com ampla diversidade genética, pertencente à família Passifloraceae, abrangendo dezoito gêneros e seiscentos e trinta espécies, sendo o gênero Passiflora o mais importante economicamente. O gênero Passiflora é composto de vinte e dois subgêneros e quatrocentos e oitenta e cinco espécies, das quais cento e cinquenta a duzentas são originárias do Brasil e podem ser utilizadas como alimentos, remédios e ornamentos (VANDERPLANK, 2000).

A fruticultura assume um importante papel social e econômico, devido à geração de alimentos e empregos e na promoção de divisas para o país com as exportações de frutas. Representa cerca de $25 \%$ do valor da produção agrícola nacional (REINHARDT, 1996). A produção mundial de frutas está em torno de quinhentos e quarenta milhões de toneladas/ano, correspondendo ao montante de US\$162 bilhões/ano. Segundo dados do Ministério da Agricultura, Pecuária e Abastecimento (MAPA, 2009), estima-se que esse ramo da agricultura empregue mais de cinco milhões de pessoas no Brasil.

O Brasil é o maior produtor mundial de maracujá, tendo em 2012 uma produção de 776.097 toneladas numa área de 59.246 hectares, sendo que o rendimento médio nacional foi de $13.416 \mathrm{~kg} \mathrm{ha}^{-1}$ (IBGE, 2014). Das aproximadamente quatrocentas e vinte espécies de Passiflora, o $P$. edulis Sims. (maracujá-azedo) e o $P$. alata (maracujá-doce) são responsáveis por 95\% da área plantada no Brasil (IBGE, 2010).

Em 2009, a espécie P. edulis Sims. ocupava, no Brasil, uma área de aproximadamente 50.795 ha com produção de 718,8 mil toneladas e produtividade de 14,15 t/ha. Em 2010, a produção brasileira foi próxima de um milhão de toneladas, entretanto, a produtividade média continuou baixa, em torno de catorze toneladas por hectare por ano (IBGE, 2012), 
considerando o potencial de produção da cultura que é superior a cinquenta toneladas por hectare por ano (FALEIRO et al., 2008); (IBGE in EMBRAPA Mandioca e Fruticultura Tropical, 2010).

A produção da fruta destaca-se nas regiões Nordeste, Sudeste e Norte do Brasil. A Bahia é o principal produtor, com 317.475 toneladas em 23.227 hectares, seguida pelo Ceará, com 129.001 toneladas produzidas em 5.579 hectares. Em terceiro lugar em produção nacional aparece o estado de Sergipe com 44.486 toneladas em 4.709 hectares (IBGE, 2011). Na região Sudeste, o maracujazeiro é uma das oito espécies frutíferas mais cultivadas no sistema extensivo, sendo precedido apenas pelas culturas da laranja, banana, limão, manga, tangerina, abacaxi e uva (SOUSA et al., 2008).

Sabe-se que no Brasil, as espécies com maior expressão comercial são a Passiflora edulis Sims (maracujá-azedo) e a Passiflora alata Curtis (maracujá-doce) (SOUZA \& MELLETI, 1997). O maracujá-azedo é o mais conhecido, cultivado e comercializado devido à qualidade de seus frutos e ao seu maior rendimento industrial. O maracujá-roxo é muito apreciado na Austrália e na África do Sul, sendo utilizado para fazer suco ou consumido como fruta fresca. O maracujá-doce tem sua produção e comercialização limitada pela falta de hábito de consumo e pelo desconhecimento pela maioria da população.

Apesar da franca expansão da cultura, tanto econômica como potencial o número de cultivares comerciais ainda é pequeno, considerando a grande variabilidade dos agroecossistemas no Brasil, bem como o número de pesquisas na área que não vem acompanhando esse incremento. Assim, o desenvolvimento de pesquisas, principalmente na área de melhoramento genético, visando à produtividade, qualidade de frutos e resistência aos principais patógenos são de extrema importância para o desenvolvimento da cultura e sua aceitação no mercado mundial como um fruto expressivo para a economia brasileira.

Ao longo dos anos, a cultura tem-se mostrado uma alternativa de renda para pequenos e médios produtores rurais, devido ao valor dos frutos comercializados. A produção brasileira de maracujá possui basicamente dois destinos: a indústria, principalmente a de extração de polpa para fabricação de suco e o consumo in natura com distribuição pelo mercado atacadista dos Ceasas. O suco e a polpa são utilizados no preparo de diversos produtos, entre os quais podem ser citados bebidas carbonatadas, bebidas mistas, xaropes, geleias, laticínios, sorvetes e alimentos enlatados (TEIXEIRA, 2014).

A cultura do maracujá, embora de grande importância econômico-social, ainda apresenta vários problemas agronômicos que dificultam seu cultivo, afetando o ciclo produtivo e, 
consequentemente, reduzindo a sua produtividade. Dentre esses problemas destacam-se os de ordem fitossanitária que comprometem a produtividade e longevidade dos plantios (TORRES FILHO, 1985).

A ocorrência de doenças constitui-se em um dos principais problemas da cultura do maracujazeiro. São comuns as doenças no sistema radicular e na parte aérea da planta. Tais doenças promovem sua morte precoce, desfolhamento, retardamento na maturação do fruto, ocorrência de frutos com baixo rendimento de polpa, e consequentemente, queda na qualidade e produtividade, causando uma série de prejuízos de ordem financeira e social.

Segundo OLIVEIRA \& FERREIRA (1991), a alternativa fornecida pelo controle curativo das doenças é onerosa e muitas vezes inviabiliza o uso adequado dos tratos culturais. A bacteriose causada por Xanthomonas axonopodis pv. passiflorae, a virose causada pelo Cowpea aphid-borne mosaic virus e os nematoides fitoparasitas se destacam entre as principais doenças que afetam o maracujazeiro. A primeira é tida como uma das principais doenças da parte aérea, provocando perdas expressivas em cultivos comerciais, sendo de ocorrência severa sob condições de clima quente e úmido (OLIVEIRA \& RUGGIERO, 1998). A segunda pode causar perdas de $50 \%$ a $80 \%$ no rendimento do maracujá, conforme mostraram experimentos realizados em São Paulo (KITAJIMA \& REZENDE, 2001). E a terceira, em um levantamento no cerrado brasileiro, revelou que $R$. reniformis estava presente em 35\% das amostras coletadas de plantas de maracujá com dois anos apresentando declínio e, M. arenaria em $47 \%$ das amostras de plantas sintomáticas (SHARMA et al., 2003b). O uso de cultivares resistentes juntamente com outras técnicas de manejo integrado são as medidas mais eficazes, econômicas e ecológicas de controle de doenças. O desenvolvimento de cultivares resistentes a doenças é importante para todas as culturas agrícolas, pois tem-se a redução de custos de produção, maior segurança de trabalhadores agrícolas e consumidores, melhor qualidade mercadológica, maior preservação do ambiente e maior sustentabilidade do agronegócio (QUIRINO, 1998). Além disso, observa-se que há outros fatores limitantes para essa cultura, como por exemplo: a baixa produtividade. Muitos fatores influenciam essa característica, sendo o cultivo de variedades inadequadas um deles (JUNQUEIRA et al., 1999). Além disso, a falta de genótipos altamente produtivos e a grande variabilidade existente em pomares comerciais refletem a necessidade do melhoramento genético dessa cultura (GONÇALVES et al., 2007). Outros fatores que influenciam na produtividade se referem a características genéticas da planta, condições edáficas, ambientais, agentes bióticos e a ação do homem (LIMA \& BORGES, 2002). 
Observa-se que os trabalhos em campo aberto, que buscam avaliar o desempenho agronômico e a resistência a fitopatógenos, dentre outras características, necessitam de um trabalho contínuo de melhoramento genético, sendo um fator limitante para o sucesso das pesquisas, visto a dificuldade encontrada pelos pesquisadores e, principalmente, pelo problema que muito tem atingido a cultura que é a pequena longevidade da lavoura. Em várias áreas de maracujazeiro-azedo plantadas no final do século passado, foram observadas lavouras em plena produção com até seis a oito anos de idade. Entretanto, nessas mesmas áreas, recentemente, as lavouras não têm ultrapassado dois anos de idade, sendo que em muitos casos, ocorre a morte total com apenas um ano de idade.

Uma ferramenta importante para o melhoramento genético do maracujazeiro é a caracterização agronômica e molecular de variedades de maracujá, orientando a escolha de genitores e o planejamento dos cruzamentos. Estudos preliminares têm mostrado que existe pouca variabilidade genética entre as cultivares para a resistência a doenças (JUNQUEIRA et al., 2003). Nesse sentido, a seleção de cultivares de maracujazeiro-azedo que apresentem boa produtividade, qualidade de frutos e resistência a fitopatógenos é essencial para o desenvolvimento da cultura no Brasil.

Sendo assim, faz-se necessário o estudo da variabilidade genética de acessos de Passiflora spp. em busca de resistência a patógenos para dar suporte ao crescimento da produção que se encontra em plena expansão no Brasil. Os programas de melhoramento genético têm sido conduzidos visando à obtenção de variedades mais produtivas e resistentes a doenças, por meio da hibridação sexual entre as espécies cultivadas e espécies selvagens. $\mathrm{O}$ estudo da diversidade genética de potenciais genitores é uma etapa básica e de fundamental importância para o sucesso de programas de melhoramento genético. Por isso, o desenvolvimento de cultivares com resistência a doenças é uma alternativa interessante, pois envolve medidas de segurança para o trabalhador agrícola e o consumidor, preservação do ambiente, redução de custos de produção, qualidade mercadológica, entre outros, sendo uma demanda atual para as pesquisas em maracujazeiro (FALEIRO et al., 2005a).

Apesar da franca expansão, têm-se ainda poucos trabalhos de pesquisa sendo desenvolvidos, notadamente na área de melhoramento genético, que visem produtividade, qualidade de frutos e resistência aos principais patógenos.

Portanto, diante do cenário exposto, torna-se necessária a obtenção de variedades e híbridos mais resistentes às doenças mais comuns e danosas ao cultivo do maracujazeiro. Segundo vários autores (CUNHA et al., 2004; JUNQUEIRA et al., 2005; PIO VIANA \& 
GONÇALVES, 2005; MELETTI et al., 2005; FALEIRO et al., 2005), o desenvolvimento de cultivares resistentes à doenças é estratégico, pois visa à redução do custo de produção, à qualidade do produto, à sustentabilidade do agronegócio e, principalmente, à preservação do meio ambiente com a redução do uso de defensivos em decorrência das incertezas dos modelos climáticos futuros. Adicionalmente, o desenvolvimento e adoção de medidas mitigadoras significativas para a adaptação da agricultura face às mudanças climáticas futuras.

É importante mencionar que a seleção de cultivares de maracujazeiro-azedo que apresentem boa produtividade, qualidade de frutos e resistência a fitopatógenos é essencial para o desenvolvimento da cultura no Brasil. Grande parte dos programas de melhoramento está relacionada ao fruto, tanto no aspecto da produtividade, quanto da qualidade. Em termos qualitativos, considera-se que uma variedade in natura, desenvolvida para o mercado deve apresentar frutos grandes e ovais, a fim de conseguir boa classificação comercial, além de ter boa aparência, ser resistente ao transporte e à perda de qualidade durante o armazenamento e a comercialização (OLIVEIRA et al., 1994). Outro índice também utilizado é a intensidade de coloração roxa ou amarela da casca (DURIGAN et al., 2004).

Diante disso, o presente trabalho buscou contribuir para o atendimento de algumas das demandas já citadas, a partir da avaliação e seleção de progênies de maracujazeiro-azedo (Passiflora edulis Sims) quanto à produtividade, resistência à virose do endurecimento dos frutos (Cowpea aphid-borne mosaic vírus), à bacteriose (Xanthomonas axonopodis pv. passiflorae), e às doenças fúngicas: antracnose (Colletotrichum gloeosporioides), septoriose (Septoria passiflorae), cladosporiose (Cladosporium herbarum) e assim objetivando selecionar progênies mais promissoras como fontes de resistências a esses fitopatógenos e sejam utilizados no programa de melhoramento de maracujá da UnB em conjunto com a Embrapa Cerrados. 


\section{OBJETIVOS}

\subsection{OBJETIVO GERAL}

Caracterizar e selecionar progênies de maracujazeiro-azedo em função do desempenho agronômico e à resistência ou tolerância aos fungos da antracnose (Colletotrichum gloeosporioides), septoriose (Septoria passiflorae) e cladosporiose (Cladosporium herbarum) e às doenças causadas pela virose do endurecimento dos frutos (Cowpea aphid-borne mosaic virus) e à bactéria (Xanthomonas axonopodis pv. passiflorae) em campo e em casa de vegetação.

\subsection{OBJETIVOS ESPECÍFICOS}

- Selecionar progênies resistentes à mancha oleosa (Xanthomonas axonopodis pv. passiflorae) e septoriose (Septoria passiflorae), sob condições de casa de vegetação.

- Estimar parâmetros genéticos e caracterizar o desempenho produtivo e agronômico das progênies de maracujazeiro-azedo no Distrito Federal.

- Selecionar progênies resistentes ou tolerantes às doenças fúngicas: antracnose (Colletotrichum gloeosporioides), septoriose (Septoria passiflorae) e cladosporiose (Cladosporium herbarum), sob condições de campo.

- Selecionar progênies resistentes ou tolerantes à mancha oleosa (Xanthomonas axonopodis pv. passiflorae), ao vírus do endurecimento dos frutos (Cowpea aphid-borne mosaic virus), sob condições de campo.

- Caracterizar a variabilidade genética de progênies de maracujazeiro, para subsidiar a seleção de genótipos e a geração de informações para seleção de genitores e aumento da eficiência do programa de melhoramento genético do maracujazeiro fazendo uso de marcadores moleculares RAPD, para subsidiar a utilização científica de tais materiais em programas de melhoramento genético. 


\section{REVISÃO DE LITERATURA}

\subsection{ASPECTOS GERAIS DO MARACUJAZEIRO}

O gênero Passiflora é originário da América do Sul e tem no centro-norte do Brasil seu maior centro de distribuição geográfica (LEITÃO-FILHO \& ARANHA, 1974, citados por MELETTI \& BRUCKNER, 2001). Há mais de quinhentos e oitenta espécies de Passifloraceae, a maioria habitante da América Tropical e muitas nativas do Brasil. Nessa família, o gênero Passiflora possui cerca de quatrocentas espécies, sendo o mais expressivo. Muitas dessas espécies possuem propriedades alimentícias, ornamentais ou medicinais, várias delas notadamente apreciadas pela qualidade de seus frutos (SOUZA \& MELETTI, 1997).

O maracujá é uma das culturas que contribuem para a condição do país como grande produtor de frutas, sendo a produção estimada em 920.000 toneladas, com área cultivada correspondente a 62.200 hectares por ano (IBGE, 2013). A produtividade média é de aproximadamente catorze toneladas por hectare, havendo potencial para produção de trinta a trinta e cinco toneladas por hectare (SILVA, 2009). Progênies elites, desenvolvidas em ações de pesquisa, chegam a produzir mais de 50t/ha/ano (FALEIRO et al., 2008).

O maracujá é produzido no Equador, Colômbia, Peru, África do Sul e Austrália, sendo o Equador o maior exportador. Segundo ARÊDES et al., (2009), o Brasil é o maior produtor mundial de maracujá, com aproximadamente $60 \%$ da produção total.

De acordo com FALEIRO et al.,(2005), Passiflorara edulis Sims. (maracujá-azedo) e Passiflora alata Curtis (maracujá-doce) são as espécies mais cultivadas, sendo estimado que essas duas espécies ocupem mais de $90 \%$ da área cultivada no mundo.

No Brasil, o gênero Passiflora apresenta um importante centro de diversidade, pois muitas espécies Passiflora são nativas, notadamente no cerrado do centro-norte do País (LOPES, 1991). Além disso, são observadas as seguintes espécies, entre outras: Passiflora alata Curtis, Passiflora caerulea L., Passiflora edulis Sims, Passiflora incarnata L., Passiflora laurifólia L., Passiflora ligularis Juss., Passiflora mollissima (HBK) Bailey e Passiflora quadrangularis L. (MARTIN \& NAKASONE, 1970; LEITÃO-FILHO \& ARANHA, 1974; BAILEY, 1975, citado por OKANO \& VIEIRA, 2001).

A família Passifloraceae tem ampla distribuição, principalmente nas regiões tropicais, mas também ocorre em regiões subtropicais, estendendo-se até ao norte da Argentina, África do Sul, Austrália, Nova Zelândia, América do Norte e Ásia. 
As flores são hermafroditas, diclamídeas, apresentando um cálice tubuloso constituído por cinco sépalas oblongas e esverdeadas e uma corola formada por cinco pétalas que podem variar de coloração de acordo com a espécie. A corola é seguida por uma corona, constituída por cinco séries de filamentos, com a presença do opérculo em sua base, que protege a câmara nectarífera. No centro da flor está presente um tubo andrógino, em cuja base se localiza o ovário. Na parte inferior do tubo estão inseridos cinco filetes terminados por anteras bem desenvolvidas e na parte superior estão os estigmas (HARDIN, 1986; MANICA et al., 1997; KAVATI, 1998).

A polinização é feita por insetos, sendo a mamangava o principal agente polinizador (AKAMINE \& GIROLAMI, 1959). As plantas, que são de dias longos, necessitam de fotoperíodos superiores a onze horas para o florescimento (VALINNI et al., 1976). O maracujazeiro é uma alógama obrigatória (MAY \& SPEARS, 1988), em que o mínimo de cento e noventa grãos de pólen são necessários para que se efetive a polinização com a produção de frutos, sendo de dois a sete grãos de pólen por cada semente formada (AKAMINE \& GIROLAMI, 1959).

Quanto ao hábito de crescimento, o maracujazeiro é uma planta trepadeira, semilenhosa, de rápido crescimento e frutificação precoce, podendo atingir cinco a dez metros de comprimento (RUGGIERO et al., 1996). O sistema radicular pode ser pivotante ou axial, sendo que a maior concentração está na profundidade entre 0 e $45 \mathrm{~cm}$ do solo (MANICA et al., 1997). As folhas do maracujá-azedo são simples, alternadas, com formas variadas, apresentando brácteas foliáceas bem desenvolvidas na base e as gavinhas, que são responsáveis pela fixação da planta em suportes (LEITÃO-FILHO \& ARANHA, 1974; MANICA et al., 1997). É uma planta perene, mas em pomares comerciais apresenta duração entre um a seis anos de vida (KUDO, 2004).

O fruto é uma baga que apresenta pericarpo carnoso, indeiscente, com sementes de coloração pardo-escura e são revestidas por arilos, de onde se extrai o suco (MANICA et al., 1997).

A propagação do maracujazeiro pode ser feita de forma sexuada, através de sementes, e assexuada, por meio da estaquia, enxertia, alporquia e cultura de tecido in vitro (FERREIRA, 2000; MELETTI, 2000). Entretanto, a quase totalidade dos plantios ainda é feita por meio de sementes, o que gera indivíduos diferentes devido à segregação existente e ao fato dessa espécie apresentar uma elevada autoincompatibilidade. Entre as vias de propagação assexuada, a enxertia apresenta grande potencial, pois além de permitir perpetuar e manter a 
genética dos melhores clones, possibilita o pleno aproveitamento das vantagens advindas dos porta-enxerto, contribuindo assim, para a obtenção de pomares geneticamente superiores aos formados por meio de sementes (RUGGIERO, 2000).

Sua potencialidade econômica está associada ao rápido retorno de capital, à preferência pelos mercados interno e externo, devido ao aroma agradável, teores de açúcares, vitaminas A e C, além da sua composição mineral, que definem a qualidade do suco (FALCONNER et al., 1998).

A fruticultura vem se destacando, atualmente, no sistema agroalimentar brasileiro, promovendo o desenvolvimento de diversas regiões, graças a mudanças nos padrões de demanda nos mercados interno e externo e do consequente crescimento tecnológico. A produção nacional de maracujá estende-se por todos os estados brasileiros e pelo Distrito Federal. A região Nordeste é a maior produtora, seguida das regiões Sudeste, Norte e Sul (DURIGAN, 1998; SOUZA, 2002). Atualmente, destacam-se os seguintes estados produtores: Bahia, Sergipe, São Paulo, Pará e Minas Gerais.

A cultura do maracujá é afetada por um grande número de doenças fazendo dos problemas fitossanitários a sua maior limitação para a cultura. Essas doenças acarretam em perda de produtividade e qualidade e diminuição da longevidade da cultura. Dentre essas doenças destacam-se as mencionadas a seguir.

\subsection{A BACTERIOSE CAUSADA POR XANTHOMONAS AXONOPODIS PV. PASSIFLORAE}

A bacteriose do maracujazeiro causada por Xanthomonas axonopodis pv. passiflorae ocorre em todas as regiões do país. Afirma-se que Xanthomonas seja um dos maiores gêneros de bactérias a possuir associação com plantas. Espécies desse gênero são responsáveis pela infecção de pelo menos cento e vinte e quatro monocotiledôneas e de duzentos sessenta e oito dicotiledôneas, enquanto outros membros são saprófitas e epífitas (MATTA, 2005).

A mancha oleosa foi descrita pela primeira vez por PEREIRA (1969), no estado de São Paulo, região de Araraquara, que classificou a bactéria como uma nova espécie, propondo a designação de Xanthomonas passiflorae. Mais tarde, DYE et al., (1980) reclassificaram a bactéria, denominando-a de Xanthomonas campestris pv. Passiflorae (GONÇALVES \& ROSATO 2000), por meio de técnicas de hibridação DNA-DNA, propuseram sua reclassificação como Xanthomonas axonopodis pv. passiflorae. 


\subsubsection{Etiologia}

A bactéria Xanthomonas axonopodis pv. passiflorae é baciliforme, gram-negativa, aeróbia restrita e móvel por um único flagelo polar. Não apresenta formação de esporos, mede 0,5 x 1,5 mm e produz pigmento amarelo xanthomonadina. Forma colônias características com nuances amarelo brilhantes, circulares, convexas, salientes, elevadas, translúcidas, bordas regulares e viscosas. Apresentam crescimento ótimo a $27^{\circ} \mathrm{C}$ (PEREIRA, 1969; PIO-RIBEIRO \& MARIANO, 1997).

Por meio de marcadores moleculares RAPD, NAKATANI (2001) identificou grande variabilidade genética entre isolados da bactéria. Foram realizados testes de patogenicidade em população de maracujá-azedo, empregando-se os cinco isolados geneticamente mais divergentes entre si, encontrando variabilidade também em patogenicidade. Estudo semelhante foi realizado por GONÇALVES \& ROSATO (2000), que mostrou a existência de alto grau de polimorfismo entre isolados de X. axonopodis pv. passiflorae, encontrando níveis de similaridade variando de $35 \%$ a $85 \%$.

\subsubsection{Epidemiologia}

A bactéria Xanthomonas axonopodis pv. passiflorae sobrevive principalmente em restos de cultura, sendo que o período de sobrevivência pode ser reduzido com o seu enterrio. A disseminação ocorre por meio de mudas e sementes contaminadas e por meio de escoamento e respingos de água da chuva ou irrigação, associados ao vento (LIBERATO \& COSTA, 2001). A disseminação também pode ser realizada por meio de ferramentas, utensílios e máquinas contaminadas (MELETTI \& MAIA, 1999). A bactéria penetra através de estômatos, hidatódios ou ferimentos, colonizando os espaços intercelulares do tecido foliar, como também dos tecidos vasculares.

\subsubsection{Sintomatologia}

Os sintomas tornam-se evidentes quando manchas de cor verde-escuro, encharcadas, translúcidas e halo amarelado tornam-se evidentes. As folhas apresentam pequenas lesões encharcadas, com aspecto oleoso, translúcido e, frequentemente, localizadas próximas às nervuras. Vistas contra a luz, as lesões apresentam halos cloróticos, podendo exibir gotículas de exsudado bacteriano. Em seguida, tornam-se mais deprimidas, na face abaxial, ocasionando seca e desintegração da área do limbo foliar (PEREIRA, 1968; TEIXEIRA, 1994; PIO-RIBEIRO \& MARIANO, 1997; DIAS, 2000). Verifica-se, também, que o sintoma 
se inicia pelos bordos foliares e caminha pelas nervuras, que adquirem uma coloração avermelhada, atingindo o pecíolo (DIAS, 2000).

Nos frutos, as manchas são grandes, inicialmente esverdeadas e oleosas, depois pardas, em geral circulares e bem delimitadas. Apesar de superficiais, essas manchas, em condições favoráveis, ajudam o patógeno a penetrar na polpa, fermentando-a e também podendo alcançar as sementes, inviabilizando a comercialização (VIANA et al., 2003).

A doença pode causar imensa desfolha, que reduz drasticamente ou mesmo impede a formação de frutos (DIAS \& TAKATSU, 1987). Podem ocorrer sintomas localizados e sistêmicos, tanto em mudas inoculadas, como em plantas adultas no campo. A infecção pode avançar através dos feixes vasculares dos pecíolos e ramos, ocasionando redução na frutificação e levando a morte da planta. Nesses feixes vasculares, por meio de corte transversal, ocorre típica exsudação bacteriana (DIAS, 2000; PEREIRA, 1969).

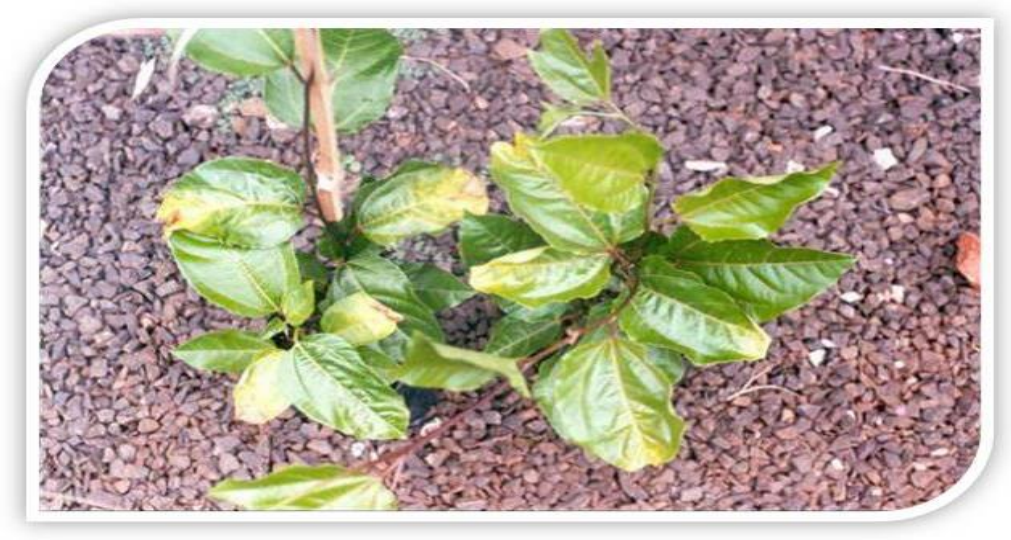

Figura 1 - Sintomas causados por Xanthomonas axonopodis pv. Passiflorae nas folhas de maracujá-azedo (MIRANDA, 2004).

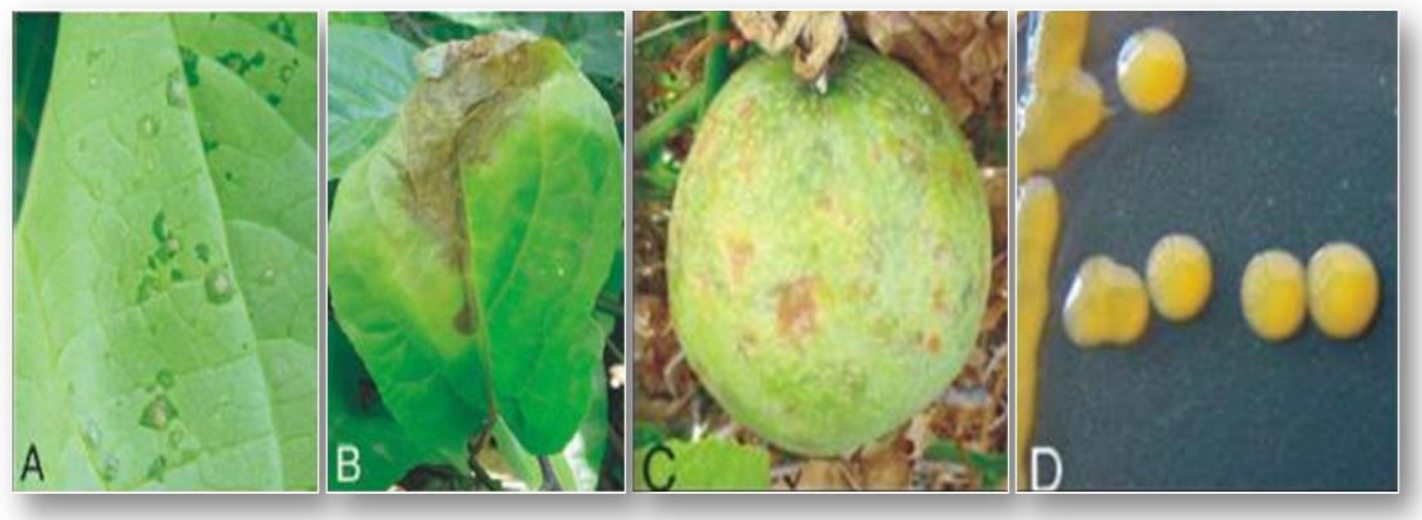

Figura 2 - A. Sintomas iniciais da mancha bacteriana do maracujazeiro; B. Queima foliar severa; C. Sintomas em fruto de maracujá; D. Colônias de Xanthomonas axonopodis pv. passiflorae em meio 523 de KADO \& HESKETT (HALFELD-VIEIRA \& NECHET, 2006). 


\subsubsection{Controle}

Dentre as principais medidas de controle destacam-se o uso de mudas e sementes sadias, poda de limpeza, uso de quebra ventos, aplicação de bactericidas (TEIXEIRA, 1994; TORRES \& PONTES, 1994) e uso de plantas resistentes ou tolerantes à bacteriose. Aplicações quinzenais com oxicloreto de cobre a $30 \%$ e a $50 \%$ e oxicloreto de cobre + Maneb + Zineb proporcionam um bom controle (TORRES \& PONTES, 1994). Segundo VIANNA et al., (2003), também é observado que a associação de um fungicida cúprico com um bactericida, como sulfato de cobre $(30 \%)+$ oxitetraciclina $(50 \%)$, resultou em bom controle da doença. O mesmo autor recomenda que no manejo da doença, por meio de poda de limpeza, seja seguido pela aplicação de uma associação de bactericidas (formulação comercial de oxitetraciclina + estreptomicina, na dosagem de $1,8 \mathrm{~kg} / \mathrm{ha}$ a cada sete dias) até a completa ausência dos sintomas.

\subsection{O VÍRUS DO ENDURECIMENTO DO FRUTO}

A virose do endurecimento dos frutos é uma das doenças mais importantes da cultura do maracujá-azedo e doce (KITAJIMA et al.,1986; REZENDE, 1994). O primeiro relato da virose do endurecimento dos frutos do maracujazeiro foi feito na Austrália há mais de cem anos (COBB, 1901). O vírus PWV e o CABMV são da família Potyviridae, do gênero Potyvirus e foram descritos como os agentes causadores do endurecimento dos frutos.

No Brasil a virose do endurecimento do fruto foi constatada pela primeira vez em plantios comerciais de maracujá-amarelo e doce, no estado da Bahia, no final da década de 70 (CHAGAS et al., 1981; YAMASHIRO \& CHAGAS, 1979). Posteriormente, foi detectada em quase todos os estados do Brasil (BARBOSA \& SANTOS FILHO, 2003). A distribuição geográfica dessa virose inclui também a Austrália, Suriname, Formosa, África do Sul, Sumatra, Quênia e Inglaterra (KITAJIMA et al., 1986).

Doenças viróticas notadamente têm causado prejuízos às lavouras de maracujazeiro no Brasil e no mundo, reduzindo produtividade e exigindo efetivo controle fitossanitário, muitas vezes comprometendo a renda do produtor (MIRANDA, 2006; KITAJIMA et al., 1986).

\subsubsection{Etiologia}

A virose do endurecimento dos frutos pode ser causada por duas espécies de vírus (Passionfruit woodiness virus, PWV e Cowpea aphid-borne mosaic virus, CABMV), e é a 
principal doença de etiologia viral do maracujazeiro no Brasil e está disseminada na maioria das regiões produtoras (KITAJIMA \& RESENDE, 2001; NASCIMENTO et al.,2006).

$\mathrm{O}$ vírus do endurecimento dos frutos PWV ou CABMV, pertence ao gênero Potyvirus, da família Potyviridae. Os potyvirus possuem partículas alongadas e flexuosas, com 690-760 mm de comprimento por 11-16 mm de largura. O genoma é constituído por um RNA de fita simples, sentido positivo, com aproximadamente 10.000 nucleotídeos (VAN REGENMORTEL et al.,2000).

Estudos realizados por BRAZ et al. (1998) citado por NASCIMENTO, (2004) constataram que diversos isolados de Potyvirus causadores do endurecimento dos frutos do maracujazeiro, provenientes dos principais estados produtores de maracujá no Brasil (São Paulo, Minas Gerais, Rio de Janeiro, Espírito Santo, Bahia, Pernambuco e Pará, além do Distrito Federal) e previamente classificados como PWV com base em características biológicas e sorológicas constituem uma estirpe do CABMV. Sendo assim, o CABMV é hoje a principal espécie do gênero Potyvirus causadora dessa doença no Brasil. Essa informação é de grande importância para a pesquisa voltada para a busca de estirpes atenuadas do vírus para proteção cruzada, e em programas de melhoramento genético visando à resistência ao endurecimento dos frutos.

Os danos são maiores quanto mais cedo as plantas forem infectadas, reduzindo número, peso e valor comercial dos frutos.

De acordo com Dos ANJOS et al., (2001) \& LEÃO (2001) nove vírus foram relatados infectando maracujazeiro em condições naturais. Destes, cinco estão presentes no Brasil: o vírus do endurecimento dos frutos (Passionfruit woodiness virus - PWV), o vírus do mosaico do pepino (Cucumber mosaic vírus - CMV), o vírus do mosaico amarelo do maracujazeiro (Passionfruit yellow mosaic vírus - PFYMV) o vírus do mosaico do maracujá-roxo (Granadilla mosaic vírus - GMV) e o vírus do enfezamento do maracujazeiro (Passionfruit vein-clearing rhabdovirus - PFVCV).

\subsubsection{Epidemiologia}

Segundo Dos ANJOS et al., (2001) e DI PIERO (2006), o PWV é disseminado de forma não persistente e não circulativa por insetos da família Aphidedae: Aphis gossypii e Mysus perssicae. Além dessa forma, o vírus pode ser também transmitido por enxertia de material infectado. Porém, afirmam os autores, não por semente. DI PIERO et al., (2006) afirmam que Aphis gossypii coloniza cerca de uma centena de espécies vegetais, sua reprodução é enorme (podendo ocorrer por partenogênese) e ocasiona danos diretos a diversas culturas na 
decorrência do seu ataque. A transmissão do vírus ocorre na picada de prova, porém estes insetos não colonizam o maracujazeiro.

\subsubsection{Sintomatologia}

Os sintomas se caracterizam com a malformação, rugosidade, clareamento das nervuras e mosaico nas folhas.

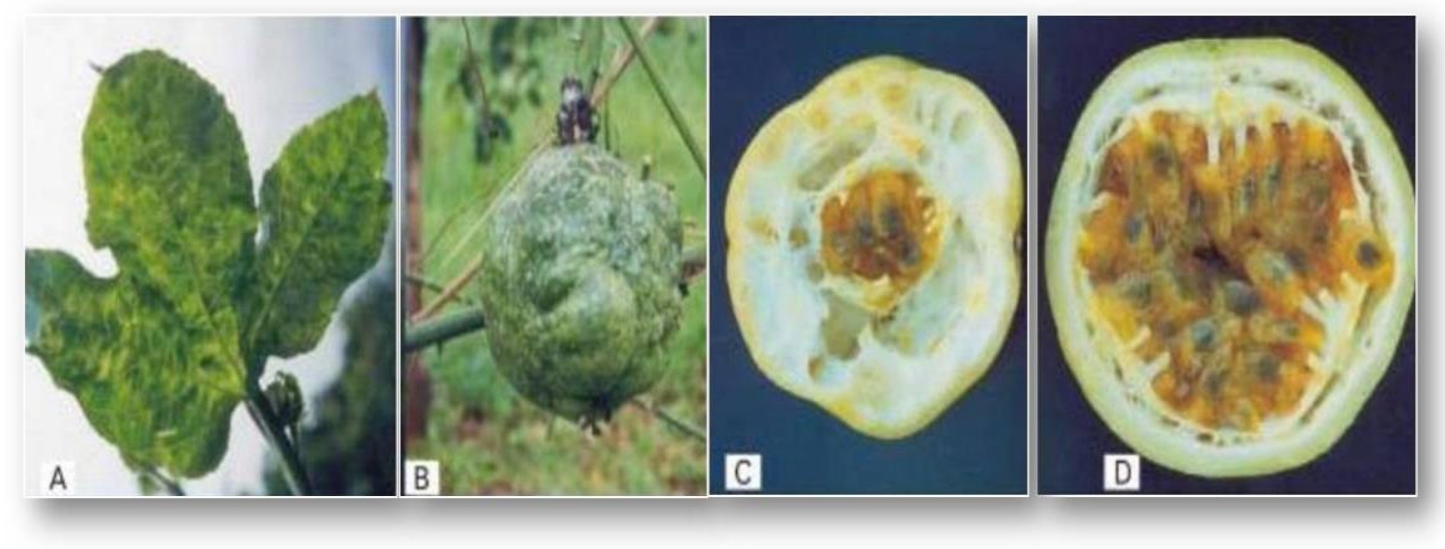

Figura 3 - Sintomas sistêmicos induzidos pelo CABMV em maracujazeiro-amarelo. Folha com mosaico A.; fruto deformado B.; fruto com pericarpo espesso e quantidade de polpa reduzida C., em comparação com fruto de planta sadia D. (ANJOS et al., 2001).
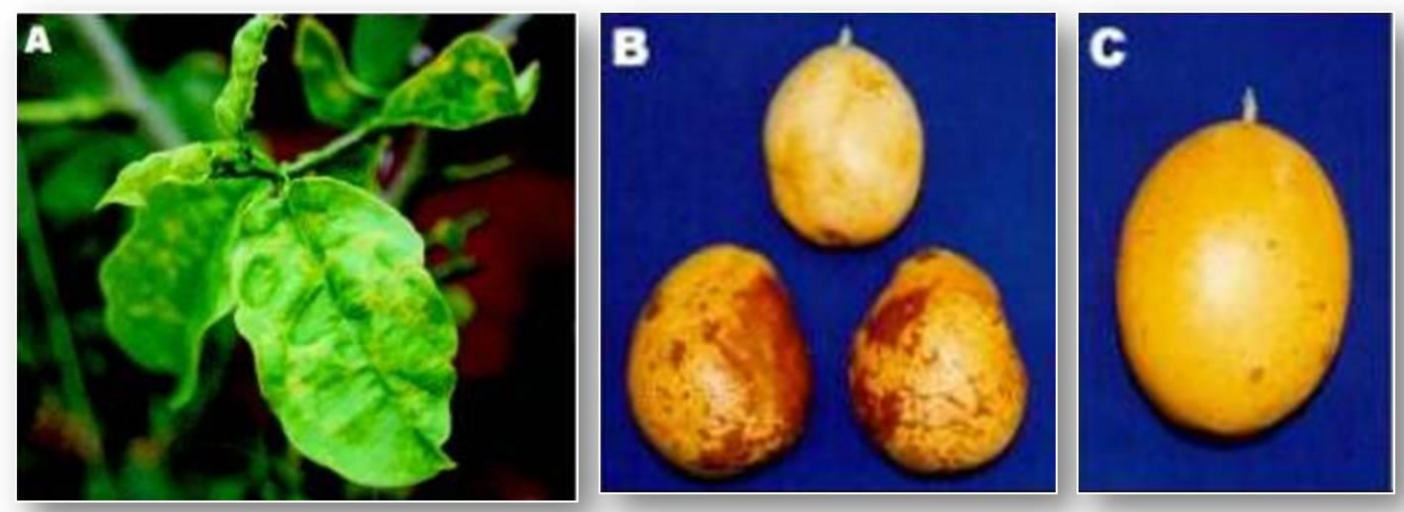

Figura 4 - Sintomas sistêmicos do CABMV em Passiflora nitida. A. Mosaico foliar; B. frutos colhidos de plantas infetadas e C. fruto de planta sadia (MORAES et al.,2002).

\subsubsection{Controle}

O controle para o vírus causador do endurecimento dos frutos, na Austrália, tem sido alcançado através da utilização de híbridos de maracujá-roxo com amarelo tolerante à doença. No Brasil, o Instituto Agronômico de Campinas lançou em 2000, uma cultivar tolerante (híbrido entre o maracujá-amarelo IAC 277 e uma variedade de maracujá-roxo nativo) de 
frutos rosados, denominado maracujá-maçã. Porém, esta cultivar produz frutos pouco apreciados no mercado, devido a sua coloração rosada, formato arredondado, peso inferior ao maracujá-amarelo e menores dimensões (FALEIRO et al.,2005).

JUNQUEIRA et al., (2000), destacou como medidas de controle mais comuns para essa doença o plantio de mudas sadias, arranquio das plantas doentes à medida que aparecerem e eliminação de hospedeiros alternativos (Crotalarea juncea, C. striata, Glycine max, Phaseolus lunatus cvs. Fava Branca e Fava Jackson, P. vulgaris, Curcubita pepo cv. Caserta) do vírus causador da doença.

\subsection{AS DOENÇAS FÚNGICAS DO MARACUJAZEIRO}

Com relação aos fungos causadores de doenças na cultura do maracujá, existem várias espécies que vêm causando danos, muitas vezes significativos, às plantas do maracujazeiro, entre as quais está o fungo causador da murcha de fusarium, Fusarium oxysporum (Schlecht.) f. sp. passiflorae Purss. A doença foi descrita na Austrália em 1951 em plantações de maracujá-roxo. No Brasil, foi relatada pela primeira vez em São Paulo, em 1968 (PIORIBEIRO \& MARIANO, 1997).

Outro importante fungo patogênico ao maracujazeiro é Glomerella cingulata (Stonem.), causador da antracnose. É uma doença que afeta a parte aérea da planta, tendo sido relatada no Brasil desde 1970, em plantações de maracujá-roxo, amarelo e doce (GOES, 1998).

A cladosporiose causada pelo fungo Cladosporium herbarum pode afetar a maioria das Passifloráceas. A doença causa uma intensa desfolha, diminuindo a produção. Em certos casos, quando associada à antracnose ou à bacteriose, pode matar um número muito grande de plantas no pomar (SANTOS FILHO \& SANTOS, 2003).

Ainda entre as doenças de origem fúngica, a septoriose é outra moléstia presente. É uma doença rara, mas potencialmente grave por causa do desfolhamento que ocasiona quando ocorre no final da estação chuvosa. Na maioria das vezes não apresenta sintomas visuais no limbo foliar (SANTOS FILHO \& SANTOS, 2003).

Outro mal que vem ocorrendo em todas as regiões produtoras do país nos últimos anos é a morte precoce do maracujazeiro, um fenômeno associado a vários patógenos da cultura e que vem reduzindo o período de produção dos maracujazeiros. Acredita-se que estes patógenos infectam plantas já debilitadas em decorrência de algum tipo de estresse (deficiência nutricional, hídrica ou de ordem fisiológica, como esgotamento repentino das reservas da planta em virtude de altas produtividades). Como forma de controle, têm sido recomendados tratos culturais adequados integrados com aplicação de fungicidas para o 
controle da antracnose e outros patógenos da parte aérea do maracujazeiro (JUNQUEIRA et al.,1999).

\subsubsection{Antracnose}

A antracnose é comumente encontrada nas regiões produtoras de maracujá do Brasil. Ocorre, principalmente, em frutos desenvolvidos e se constitui na mais importante doença pós-colheita da cultura, reduzindo o período de conservação dos frutos. Assume maior importância quando as condições climáticas são favoráveis, pois seu controle torna-se difícil. Sua ocorrência, associada à da mancha bacteriana, pode agravar ainda mais o problema (FISCHER et al., 2005).

\subsubsection{Etiologia}

O agente da antracnose é o fungo Glomerella cingulata (Stoneman), cuja fase anamórfica corresponde o fungo Colletotrichum gloeosporioides (FISCHER et al.,2005).

$\mathrm{O}$ gênero Colletotrichum abrange os fungos imperfeitos pertencentes à ordem Melanconiales da classe Coelomycetes, os quais apresentam uma associação teleomófica com isolados homotálicas ou heterotálicas do ascomiceto do gênero Glomerella (SKIPP et al.,1995). As espécies de Colletotrichum apresentam uma ampla distribuição geográfica, particularmente em ambientes quentes e úmidos dos trópicos (JEFFRIES et al.,1990; WALLER, 1992) e são extremamente diversas, incluindo saprófitas e fitopatógenos. Os patógenos ocorrem em diversas espécies de hospedeiros, desde culturas agrícolas e plantas medicinais, aos arbustos e árvores silvestres, causando podridões de colmos, caules e frutos, seca de ponteiros, manchas foliares, infecções latentes e antracnoses. O último termo descreve doenças caracterizadas por lesões necróticas profundas e delimitadas nos tecidos (AINSWORTH, 1971).

Os prejuízos causados pelo gênero Colletotrichum, em especial em países tropicais, resultam tanto na redução direta da qualidade e, ou quantidade dos produtos, como no aumento dos custos de produção e de pós-colheita onde as infecções latentes não foram detectadas durante o cultivo (SKIPP et al.,1995).

Dentre as espécies desse gênero, C. gloeosporioides é considerada a mais disseminada, heterogênea e importante, principalmente nos trópicos. Seus conídios são hialinos e unicelulares, produzidos no interior de acérvulos subepidérmicos dispostos em círculos (FISCHER et al., 2005). Geralmente, são formados em conjuntos de coloração salmão, retos e cilíndricos, com ápices obtusos e bases às vezes truncadas, medindo $12-17 \mu \mathrm{m}$ x 3,5-6 $\mu \mathrm{m}$. Os conídios formados por esta espécie são clavados, ovóides, obovados ou lobados, de coloração 
castanha e medindo 6-20 $\mu \mathrm{m}$ x 4-12 $\mu \mathrm{m}$. Forma colônias variáveis de coloração branco-gelo a cinza-escuro e micélios aéreos, geralmente uniformes, aveludados (SUTTON, 1992).

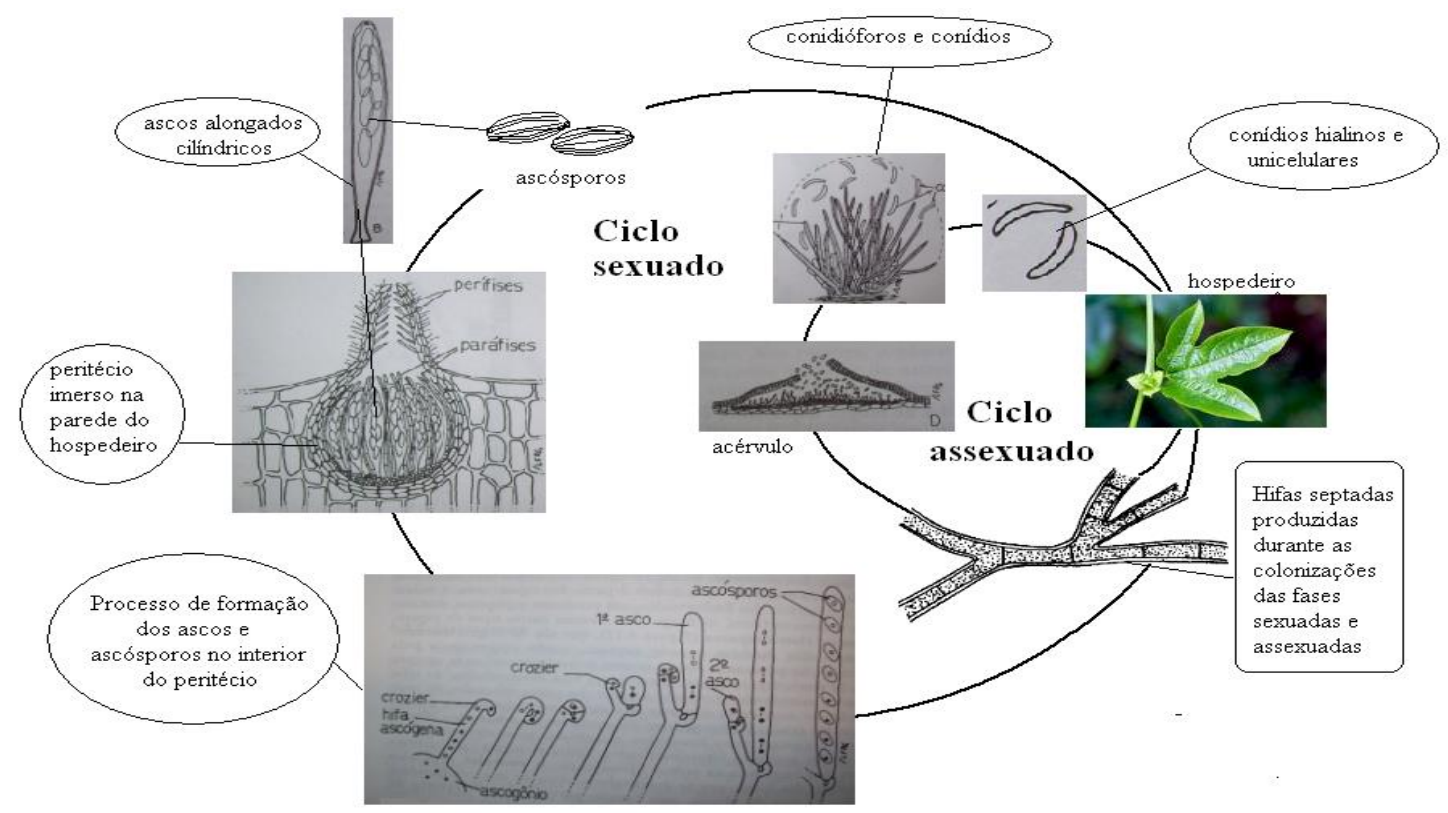

Figura 5 - Ciclo de vida do Colletotrichum gloeosporioides (KRUGNER et al.,1995).

\subsubsection{Epidemiologia}

Os danos causados por este patógeno são mais expressivos em plantios adultos, geralmente após o primeiro pico de safra, chegando a provocar secas de galhos e morte de plantas. O fungo infecta tecidos novos e brotações, podendo permanecer em estado latente ou quiescente, sem mostrar sintomas até que as condições climáticas se tornem favoráveis e, ou a planta sofra algum tipo de estresse, quer seja nutricional, hídrico ou por excesso de produção. Quando isso acontece, geralmente as plantas começam a secar (JUNQUEIRA et al.,2005).

O agente causal sobrevive em folhas infectadas caídas ou em outras plantas hospedeiras vizinhas dos pomares. Como os propágulos desse fungo são disseminados por respingos de água, o C. gloeosporioides é favorecido por alta umidade, principalmente chuvas abundantes. A temperatura próxima de $27^{\circ} \mathrm{C}$ favorece a produção dos conídios. Chuvas menos intensas favorecem o progresso da doença numa mesma planta já infectada e chuvas acompanhadas de ventos tendem a transportar o fungo para outras plantas. Em períodos de temperaturas mais baixas, a importância da doença diminui, sendo pequena a sua incidência nos meses de inverno, mesmo que ocorram chuvas (RUGGIERO et al.,1996). 


\subsubsection{Sintomatologia}

Todos os órgãos aéreos da planta, como folhas, botões florais, gavinhas, ramos e frutos podem ser infectados. Nas folhas são produzidas manchas inicialmente pequenas, de 2: $3 \mathrm{~mm}$, de aspecto oleoso, adquirindo, posteriormente, cor pardo-escura, de formato irregular e diâmetro superior a $1 \mathrm{~cm}$. Na parte central das manchas, os tecidos tornam-se acinzentados, podendo ocorrer fendilhamento. Sob condições ambientais favoráveis (temperatura e umidade elevadas), surgem várias lesões no limbo foliar, provocando coalescência e ocupando grandes áreas, causando grande queda de folhas (GOES, 1998).

Nos ramos e gavinhas afetados são produzidas manchas pardo-escuras de 4 a $6 \mathrm{~mm}$ que, posteriormente, se transformam em cancros, expondo os tecidos lesionados. Dependendo da intensidade da doença pode ocorrer morte dos ponteiros e secamento parcial da planta (GOES, 1998).

Inicialmente, nos frutos, os sintomas são caracterizados pela presença de lesões marrons com halo esverdeado, às vezes na forma de pequenas pontuações verdes. Sob condições de armazenamento, as lesões adquirem coloração marrom, aumentam de tamanho, podendo atingir até $3 \mathrm{~cm}$ de diâmetro. Com o tempo, as lesões coalescem, tomando toda a superfície do fruto. Sobre as lesões, em condições de alta umidade, podem surgir frutificações de cor rosa e, ou pontuações escuras dispostas na forma de anéis concêntricos. A doença é mais severa nos frutos desenvolvidos durante o período chuvoso (JUNQUEIRA et al.,2003).

\subsubsection{Controle}

O controle dessa doença no maracujazeiro, assim como nas fruteiras em geral, deve ser iniciado no campo. Frutos com muita incidência da doença, no momento da colheita, frequentemente desenvolvem sintomas dessa, por melhores que sejam os métodos de póscolheita empregados para seu controle (SIGRIST, 2003). Como medidas culturais de controle da antracnose que devem ser realizadas em campo, recomendam-se a realização de podas de limpeza e a remoção de restos culturais como folhas e frutos, uso de mudas sadias, produzidas em locais onde não ocorra a doença, manejo da irrigação e adubação equilibrada. Na fase póscolheita, o manuseio adequado dos frutos evita os ferimentos, o que reduz os danos causados pela doença (VIANA \& COSTA, 2003; JUNQUEIRA et al.,2003; FISCHER et al.,2005).

Até o momento, não há registros de cultivares de maracujá com algum tipo de resistência à antracnose. Entretanto, estudos realizados no Distrito Federal mostraram que a cultivar roxo-australiana foi resistente à antracnose na pós-colheita em comparação com as cultivares Maguari, Marília e Vermelho (JUNQUEIRA, 2003). 
Estudos recentes têm demonstrado que isolados de Trichoderma koningii Oudem apresentam potencial antagônico a $C$. gloeosporioides em frutos e plantas de maracujá, indicando a possibilidade de seu uso no controle da doença em campo (ROCHA \& OLIVEIRA, 1998; FISCHER, 2005).

Para a utilização no controle químico são citados os fungicidas do grupo dos benzimidazóis, cúpricos, ditiocarbamatos, chlorotalonil e tebuconazole (FISCHER, 2005). Durante a fase de frutificação, recomenda-se fazer de 3-4 pulverizações preventivas com fungicidas protetores, aplicados em intervalos de 7-14 dias durante chuvas intensas e prolongadas, e de 15-30 dias sob chuvas regulares, podendo-se dispensar as pulverizações no período de estiagem.

\subsubsection{Septoriose}

A doença septoriose causada por Septoria passiflorae Syd ocorre em várias regiões produtoras, porém somente esporadicamente chega a causar danos significativos, principalmente em viveiros e lavouras onde o controle químico para prevenção de epidemias de doenças fúngicas é deficiente (FISCHER et al., 2005).

\subsubsection{Etiologia}

O fungo Septoria passiflorae Syd, segundo a classificação de SUTTON (1980), pertence à divisão Eumycota, subdivisão Deuteromycotina, classe Blastodeuteromycetes, subclasse Holoblastomycetidade, ordem Blastales, subordem Blastopycnidiineae. Essa classificação foi feita baseando-se no tipo de conidiogênese e conidioma. Atualmente, entretanto, a classificação dos fungos mitospóricos é feita segundo a sua fase perfeita ou teleomorfo e, neste caso, é o fungo Mycosphaerella sp. Esse fungo pertence ao filo Ascomycota, classe Ascomycetes, subclasse Dothydeomycetidae, ordem Mycosphaerellales, família Mycosphaerellaceae (KIRK et al., 2001)

A fase anamórfica do fungo apresenta micélio imerso, ramificado, septado e coloração marrom. Os picnídios são escuros, imersos e globosos, medindo entre 70 e $100 \mu \mathrm{m}$ de diâmetro e, segundo SYDOW (1939), podem ser abertos ou simplesmente rompidos. Não apresentam conidióforos e a célula conidiogênica é do tipo holoblástico. Os conídios são numerosos, hialinos, multisseptados, filiformes de ambos os lados ou apenas levemente obtusos e arredondados, além de apresentarem constrição nos septos (SUTTON, 1980).

Esse patógeno foi relatado pela primeira vez no Peru, na província de Quito, em plantas de Passiflora malissima, por SYDOW em 1939. Atualmente, pode ser encontrada na África, Oceania, oeste da Índia, América Central e América do Sul (PUNITHALINGHAM, 1980), e 
é citada como uma das principais doenças do maracujazeiro na Austrália (INCH, 1978). No Brasil já foi causa de sérios danos, mas hoje, sua ocorrência tem sido de menor frequência se comparada a outras doenças, principalmente à antracnose. Entretanto, em algumas regiões, relatos de grandes prejuízos causados pelo fungo têm sido feitos, tanto em mudas de viveiros como em plantas adultas (GOES, 1998). YAMASHIRO et al., (1973) e LIBERATO et al., (1995) observaram desfolha quase total e morte de mudas em viveiros. Na região dos cerrados é considerada uma importante doença em pomares de maracujá-azedo (NASCIMENTO et al., 2000).

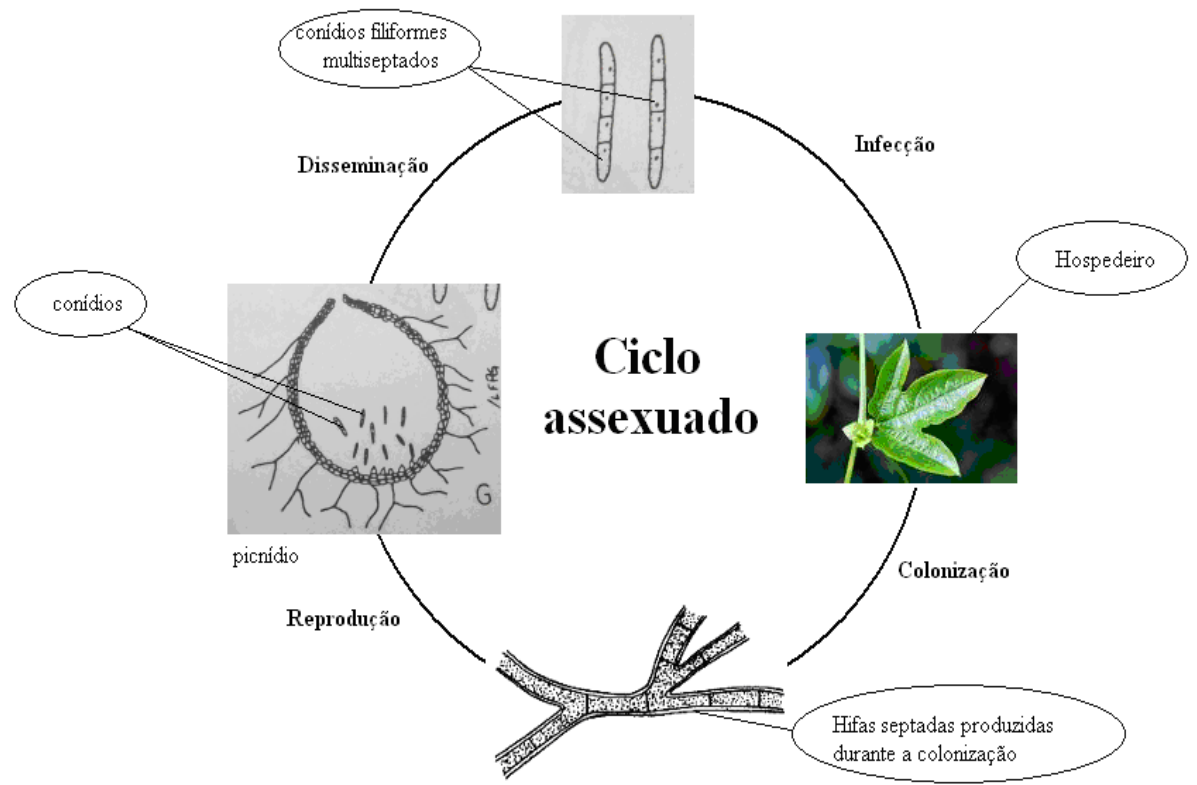

Figura 6 - Ciclo de vida da Septoria passiflorae (KRUGNER et al.,1995).

\subsubsection{Epidemiologia}

As condições favoráveis de desenvolvimento da doença são a alta umidade e as altas temperaturas (JUNQUEIRA et al., 1999) e, por esta razão, é mais comum no final da estação chuvosa (RIZZI et al., 1998). A gama de hospedeiros abrange várias espécies do gênero Passiflora.

Em trabalho desenvolvido por PINTO (2002) em casa de vegetação foi relatado que a infecção pelo fungo é rápida, aliada a sua grande facilidade de disseminação. O período de maior porcentagem de desfolha ocorre entre o $7^{\circ}$ e $14^{\circ}$ dia após a inoculação. No entanto, ainda são quase inexistentes os dados disponíveis sobre a epidemiologia da doença, havendo necessidade de estudos mais aprofundados relacionados aos aspectos epidemiológicos da septoriose. 


\subsubsection{Sintomatologia}

Os sintomas da doença foram descritos originalmente por SYDOW, em 1939. De acordo com esse autor, os sintomas se manifestam na forma de manchas distintas nas folhas das plantas, amplamente esparsas, bem regulares em órbitas circulares ou levemente angulares com 1- 4mm de diâmetro, limitadas por uma linha mais escura. Os picnídios são epífilos e subepidermais, apresentando-se nas lesões em pequenas quantidades.

Com o desenvolvimento da doença, as lesões nas folhas adquirem um halo com contorno amarelado (DIAS, 1990). Apenas uma única lesão por folha é capaz de ocasionar sua queda. Nas plantas afetadas, mesmo as folhas sem sintomas aparentes e de diferentes idades podem cair precocemente, o que pode resultar na seca de ramos e, algumas vezes, na morte da planta (GOES, 1998). A desfolha intensa pode também levar à queda dos frutos ainda verdes ou à infecção desses pelo fungo, que pode ocorrer em qualquer estádio de desenvolvimento. São produzidas nos frutos infectados as lesões pardo-claras, com halo esverdeado, medindo até 3 mm de diâmetro, as quais podem coalescer e cobrir áreas extensas do fruto, levando ao desenvolvimento ou amadurecimento irregular ( $\mathrm{INCH}$, 1978). Além disso, as lesões de septoriose podem favorecer o desenvolvimento da antracnose e da podridão de Botryodiplodia (NASCIMENTO et al., 2000).

A incidência do fungo nas flores leva ao secamento destas, causando abortamento. Na haste, as lesões são pequenas, irregulares, circulares ou alongadas com áreas encharcadas. Quando hastes de plantas jovens são afetadas, podem ficar rodeadas por um tecido necrosado como resultado da morte dos tecidos (PUNITHALINGAM, 1980).

\subsubsection{Controle}

Relata-se que pulverizações preventivas nas plantações apresentam eficiência no controle da septoriose (YAMASHIRO, 1987). SÃO JOSÉ (1993) relata que o controle pode ser feito através de duas a três aplicações de fungicidas à base de tiofanato metílico misturado com clorotalonil ou tiabendazole, de forma similar ao controle preconizado para antracnose e verrugose. PUNITHALINGAM (1980) reportou o fungo como sendo resistente ao benomyl. INCH (1978) relata o uso de Mancozeb (1,5 g/l) nos períodos sem sol para o controle do fungo. Dentre os fungicidas protetores, são utilizados os cúpricos, que são aplicados preventivamente (GOES, 1998).

Algumas práticas culturais são recomendadas para o controle da septoriose como plantar mudas em fileiras e fazer podas de limpeza, visando o arejamento, a penetração da luz solar e a eliminação de focos da doença; instalar viveiros de mudas distantes de lavouras adultas e 
contaminadas (GOES, 1998); evitar alta densidade de folhagem para facilitar a penetração de fungicidas e para evitar um ambiente com alta umidade, o que facilita a esporulação e a colonização das folhas pelo patógeno (INCH, 1978).

O uso de progênies resistentes ainda não é possível devido à falta de fontes conhecidas de resistência ao fungo S. passiflorae. Em decorrência da grande variabilidade genética existente entre genótipos de maracujazeiro, a obtenção de cultivares resistentes ou tolerantes constitui um campo de pesquisas muito promissor.

\subsubsection{Cladosporiose ou Verrugose}

A cladosporiose afeta o desenvolvimento dos tecidos jovens, reduzindo a produção (FISCHER et al., 2005) e ocorre em todas as zonas produtoras do Brasil.

\subsubsection{Etiologia}

O fungo Cladosporium herbarum Link, segundo a antiga classificação dos fungos mitospóricos, pertence à subdivisão Deuteromycetes, ordem Moniliales, família Dematiaceae. Atualmente, a classificação dos fungos anamórficos é feita através da sua fase perfeita ou teleomorfo, que é Mycosphaerella tassiana Johans, e que, segundo KIRK et al., (2001), é pertencente ao filo Ascomycota, classe Ascomycetes, subclasse Dothydeomycetidade, ordem Mycosphaerellales, família Mycosphaerellaceae.

A espécie $C$. herbarum é a espécie tipo do gênero Cladosporium. Ela apresenta grande abundância de conídios. Os conídios são produzidos em conidióforos grandes e escuros que podem se ramificar no ápice. Os conídios estão dispostos nos conidióforos em grupos ramificados, tendo os conídios mais jovens seu desenvolvimento a partir do ápice ou das laterais dos conídios mais maduros, formando cadeias acropetais simples ou ramificadas. $\mathrm{O}$ fungo apresenta conidiogênese blástica. 


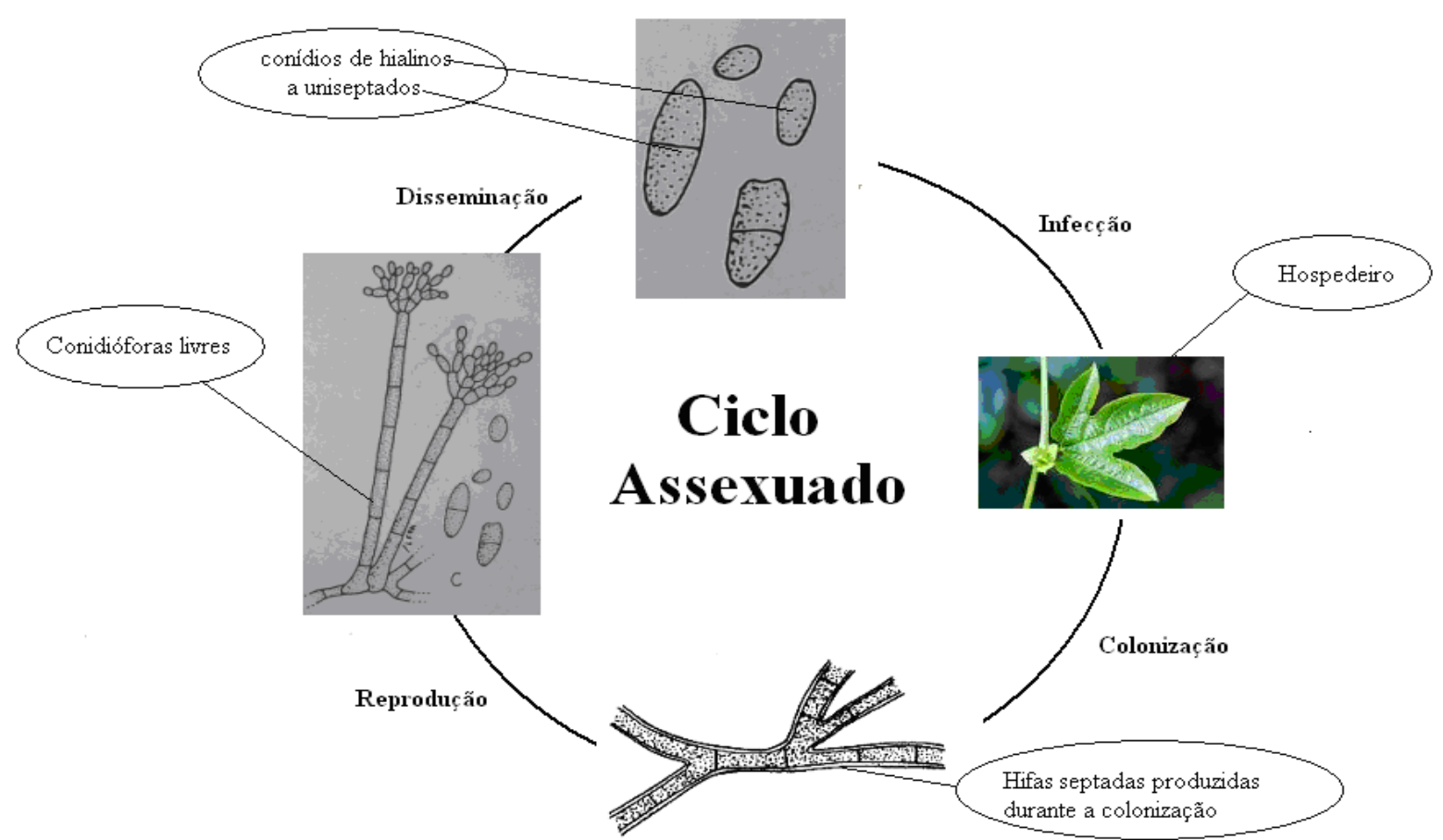

Figura 7 - Ciclo de vida do Cladosporium herbarum (KRUGNER et al.,1995).

\subsubsection{Epidemiologia}

É uma doença que ocorre preferencialmente em tecidos jovens da planta que, sob condições de alta umidade e temperaturas amenas, pode ocorrer em qualquer órgão da parte aérea. Em estações ou regiões de clima quente, é mais frequente nas partes externas dos órgãos florais, especialmente nas brácteas e no cálice (GOES, 1998).

Segundo JUNQUEIRA et al., (1999), nas áreas de plantios próximas a Brasília, a doença começa a aparecer com as primeiras chuvas dos meses de outubro e novembro e ataca principalmente ramos e folhas novas, mas torna-se muito severa de janeiro a abril. As floradas que ocorrem nesse período são as mais afetadas, pois, além do baixo vingamento, dão origem a frutos infectados pela verrugose. No período de agosto a dezembro, a cladosporiose diminui o número de lesões nos frutos. No período de janeiro, ela aparece em baixa incidência nos frutos colhidos e atinge a máxima incidência nos frutos colhidos em março e abril.

\subsubsection{Sintomatologia}

O fungo C. herbarum é o agente causal da verrugose ou cladosporiose, uma doença de múltiplas manifestações, ocorrendo em folhas, ramos, gavinhas e botões florais, sendo também conhecida como cancro dos ramos novos e perfurações foliares. É uma das principais doenças do maracujazeiro, manifestando-se, principalmente, em tecidos na fase de 
crescimento, o que prejudica o desenvolvimento da planta e reduz a produção. Ela ocorre comumente nas diferentes regiões produtoras do Brasil e também em diversos países.

Nas folhas, os sintomas se apresentam na forma de pequenas manchas circulares $(0,5 \mathrm{~mm}$ de diâmetro) inicialmente translúcidas, tornando-se necróticas posteriormente. Em condições de alta umidade, podem ser vistos sinais pulverulentos cinza-esverdeados. Pode haver deformação ou encarquilhamento quando as lesões ocorrem próximas ou sobre as nervuras. Em alguns casos, o rompimento no centro da lesão causa perfuração da folha (PIO-RIBEIRO \& MARIANO, 1997).

Em ramos, gavinhas e ponteiros afetados são formadas, inicialmente, lesões semelhantes às das folhas, mas em maior diâmetro (3 a $5 \mathrm{~mm}$ ), alongadas e deprimidas na forma de cancro e de coloração parda (GOES, 1998), onde surgem os sinais. Pode haver formação de calo cicatricial. Os ramos tornam-se fracos e quebradiços à ação do vento (PIO-RIBEIRO \& MARIANO, 1997).

Nos botões florais afetados são observadas lesões alongadas de cerca de $5 \mathrm{~mm}$ de comprimento e de coloração parda. A ocorrência de poucas lesões por botão floral não ocasiona a queda deste e, consequentemente, não afeta a frutificação. No entanto, quando ocorrem em elevado número ou quando as lesões ocorrem no pedúnculo, há queda dos botões florais.

Os sintomas nos frutos ocorrem na forma de manchas circulares translúcidas de cerca de $5 \mathrm{~mm}$ de diâmetro. Posteriormente, recobrem-se de tecido áspero de cor parda e com vários milímetros de altura (GOES, 1998) devido ao desenvolvimento do tecido corticoso e saliente sobre as lesões inicialmente planas, dando ao fruto um aspecto verrugoso (PIO-RIBEIRO \& MARIANO, 1997). Em um mesmo fruto podem ocorrer várias lesões, o que acaba causando sua deformação, prejudicando sensivelmente seu crescimento e reduzindo seu valor comercial, embora, internamente, a semente e a qualidade do fruto não sejam afetadas pela doença. Além disso, quando em elevada incidência, a doença pode atrasar o início do florescimento e a produção da planta (GOES, 1998).

\subsubsection{Controle}

A disseminação da cladosporiose se dá, além de outras formas, por meio de mudas infectadas (PIO-RIBEIRO \& MARIANO, 1997). Além dessa, o controle da doença é feito baseando-se na adoção de várias outras medidas, desde as fases iniciais de implantação até a fase de colheita, semelhantes àquelas adotadas para o controle da antracnose, tais como: instalar viveiros de mudas distantes de lavouras adultas e contaminadas; realizar podas de 
limpeza para eliminação de focos da doença, seguida de aplicação de fungicida de efeito protetor, como aqueles à base de cobre ou os carbonatos; evitar armazenamento prolongado dos frutos; controlar adequadamente as pragas (GOES, 1998).

Segundo o mesmo autor, quando detectada a presença da doença, o controle pode ser feito por meio do uso de fungicidas de efeito curativo, como os benzimidazóis, tais como o benomyl, tiofanato metílico e carbendazim. Formulações mistas de fungicidas de ação protetora e curativa também têm propiciado bom controle da doença.

\subsection{QUANTIFICAÇÃO DE DOENÇAS DE PLANTAS}

A quantificação de doenças é considerada uma das fases mais importantes no manejo de doenças de plantas (KRANZ, 1988), sendo necessária tanto para estudos de medidas de controle e de caracterização de resistência varietal como para estudos epidemiológicos e estimativas de danos por ela provocados (AMORIM, 1995; BERGAMIN FILHO \& AMORIM, 1996). Algumas variáveis que foram analisadas na presente pesquisa serão descritas resumidamente a seguir.

\subsubsection{Curva de progresso da doença}

Quando se deseja realizar a representação da epidemia de uma dada doença, a melhor maneira é através da curva de progresso, que é expressa pela plotagem da proporção da doença versus o tempo. Através dela, as interações entre patógeno, hospedeiro e ambiente podem ser caracterizadas, as estratégias de controle podem ser avaliadas e os níveis futuros de doença podem ser previstos (BERGAMIN FILHO \& AMORIN, 1996).

As curvas de progresso da doença podem ser construídas para qualquer patossistema. Os parâmetros importantes da curva de progresso da doença, tais como: época de início da epidemia, a quantidade de inóculo inicial $\left(\mathrm{X}_{0}\right)$, a taxa de aumento da doença $(\mathrm{r})$, a forma da curva de progresso da doença, a Área Abaixo da Curva de Progresso da Doença (AACPD), as quantidades máximas $\left(\mathrm{X}_{\max }\right)$ e final $\left(\mathrm{X}_{f}\right)$ de doença e a duração da epidemia, podem ser caracterizadas (BERGAMIN FILHO, 1995).

\subsubsection{Severidade}

A severidade (porcentagem da área ou volume de tecido da planta coberto por sintomas) é a variável mais utilizada para quantificar doenças foliares (BERGAMIN FILHO \& AMORIM, 1996). A severidade de doenças é geralmente avaliada visualmente, o que faz com que sejam geradas estimativas subjetivas. A avaliação da severidade da mancha bacteriana em maracujazeiro tem sido feita com o auxílio de escalas de notas (KURODA, 1981; 
WENDLAND, 1997). Entre as vantagens do emprego dessa variável para a quantificação de doenças, pode-se citar o fato de ser mais precisa expressando o dano real causado pelos patógenos, a melhor caracterização do nível de resistência a um patógeno, pelo fato de ser quantitativa. Entre as desvantagens, está o fato de ser mais trabalhoso e demorado, subjetivo, dependente da acuidade do avaliador e da escala (MORAES, 2007).

\subsubsection{Incidência}

A incidência é a porcentagem (frequência) de plantas doentes ou partes em uma amostra ou população (AMORIM, 1995). Apresenta como vantagens a facilidade e rapidez de execução, a reprodutibilidade dos resultados e o fato de ser um parâmetro satisfatório na fase inicial da epidemia, podendo ser usado na elaboração de curvas de progresso da doença. Como desvantagens apresentam pouca precisão para doenças foliares, mostrando uma correlação duvidosa com a severidade em fases avançadas da epidemia (MORAES, 2007).

\section{6 MELHORAMENTO GENÉTICO DO MARACUJAZEIRO}

Entre as várias espécies do gênero Passiflora nativas do Brasil, algumas têm características interessantes que poderiam ser introduzidas no maracujazeiro comercial. Além da resistência a doenças e a algumas pragas, há espécies autocompatíveis como a $P$. tenuifila Killip, P. cf. elegans Mast., P. capsularis L., P. villosa Vell., P. suberosa L., P. morifolia Mast. e P. foetida L. Essa característica é importante para aumentar a produtividade e reduzir custos com mão de obra para a polinização manual, bem como para reduzir o impacto negativo provocado pelas abelhas africanizadas, que perfuram a câmara nectarífera e removem todo o seu néctar antes da abertura das flores e, quando estas se abrem, retiram a maior parte de grãos de pólen, resultando em menor número de visitas dos polinizadores naturais e murchamento das flores (FANCELLI \& LIMA, 2004; JUNQUEIRA et al., 2005).

Algumas espécies de maracujá podem interferir no comportamento ou desenvolvimento dos insetos-praga, sendo essas informações úteis em programas de melhoramento de plantas para a obtenção de variedades promissoras, com características agronômicas adequadas e resistência. Segundo estudo realizado por LARA et al. (1999), citados por FANCELLI \& LIMA (2004), Passiflora nitida, P. alata, P. setacea e o híbrido P. alata X P. macrocarpa apresentam resistência do tipo não-preferência para a alimentação de Dione juno juno.

Considerando a grande variabilidade do maracujazeiro, programas de melhoramento genético têm sido conduzidos visando à obtenção de variedades mais produtivas e resistentes a doenças (BARBOSA, 1998). Como sabemos o maracujazeiro apresenta grande variabilidade genética natural para as diversas características da planta e do fruto. A 
caracterização e a avaliação das espécies de interesse são ferramentas indispensáveis aos trabalhos de fitomelhoramento. Devido ao fato do maracujá ser uma planta alógama, vários são os métodos de melhoramento aplicados a essa cultura. Métodos de melhoramento de plantas alógamas baseiam-se, principalmente, no aumento da frequência de alelos favoráveis ou na exploração do vigor híbrido (MELETTI \& BRUCKNER, 2001).

De acordo com PIO VIANA \& GONÇALVES (2005) o melhoramento genético relacionado à cultura do maracujazeiro visa três pontos considerados principais: o atendimento às exigências do mercado quanto à qualidade, aumento na produtividade e resistência a doenças.

Os principais métodos de melhoramento genético utilizados em Passiflora são introdução de plantas, seleção massal, hibridação sexual interespecífica, hibridação sexual intervarietal e seleção por teste de progênies (BRUCKNER \& OTONI, 1999). MELETTI et al. (2000). NASCIMENTO et al. (2003) trabalhando com seleção massal em P. edulis f. flavicarpa, lograram êxito em selecionar progênies promissoras, resultando, inclusive, no lançamento de cultivares comerciais.

Outros autores já relatam que espécies silvestres de maracujá nativas e espontâneas no centro-norte brasileiro também são alternativas para a ampliação da base genética da resistência. Entretanto, trabalhos de melhoramento genético são necessários para combinar a resistência com características de produtividade e qualidade de frutos. Os métodos de melhoramento baseados em hibridações interespecíficas têm sido citados como promissores, embora possam existir alguns problemas com os híbridos F1, relacionados a macho esterilidade, viabilidade de pólen, falta de adaptação e suscetibilidade às doenças de parte aérea (OLIVEIRA \& RUGGIERO, 1998). Na Embrapa Cerrados, o método de retrocruzamento tem sido utilizado para a incorporação de genes de resistência em variedades comerciais (JUNQUEIRA et al., 2005).

A seleção massal é eficiente para caracteres de fácil mensuração, com considerável herdabilidade e com a predominância de efeitos genéticos aditivos. A seleção com teste de progênie baseia-se mais na capacidade da planta em gerar bons descendentes do que no seu próprio desempenho. Segundo OLIVEIRA (1980), no maracujazeiro-amarelo, a seleção massal é eficiente para produção, formato do fruto, teor de suco, teor de sólidos solúveis e vigor vegetativo.

A seleção com teste de progênies baseia-se mais na capacidade da planta em gerar bons descendentes do que no seu próprio desempenho. Esse teste pode ser realizado com progênies 
de meio-irmãos ou de irmãos completos. Progênies de meio-irmãos podem ser facilmente obtidas, coletando-se um fruto por planta selecionada. Possuindo, geralmente, mais de 300 sementes/fruto, sendo que cada fruto é suficiente para gerar uma progênie de meio-irmãos, com várias repetições. A obtenção de progênies de irmãos completos necessita de polinização controlada entre plantas selecionadas, também viável em programas de melhoramento genético (BRUCKNER \& OTONI, 1999).

Outro método de melhoramento é a seleção recorrente que envolve a obtenção das progênies, seu intercruzamento e sua avaliação (RAMALHO et al., 2000). O policruzamento é um método de cruzamento que favorece a recombinação do material genético. Cada clone é circundado pelo maior número possível de genótipos diferente dele, e isso favorece o cruzamento em alógamas e maximizam a probabilidade de haver novas combinações genéticas. No maracujazeiro podemos tentar viabilizar o policruzamento seguido de seleção recorrente.

A produção de híbridos também apresenta um grande potencial de uso na cultura do maracujazeiro, frente às suas inúmeras vantagens. Os híbridos são obtidos a partir de linhagens endogâmicas selecionadas, variedades de polinização aberta, genótipos ou outras populações divergentes. Linhagens endogâmicas de maracujazeiro-azedo poderão ser obtidas por meio de cruzamento entre plantas irmãs, retrocuzamentos ou autopolinização no estádio de botão. A realização de autofecundações proporciona maior endogamia (FALCONER et al., 1998).

Para MELETTI \& BRUCKNER (2001), o melhoramento genético deve visar a um melhor desempenho na produção e produtividade do maracujá, com a obtenção de frutos com padrão de qualidade quanto ao sabor, acidez, tamanho dos frutos, vigor e rendimento de suco, como também, a resistência a doenças. As espécies não cultivadas $P$. setacea, $P$. cincinatta, $P$. caerulea, P. incarnata, P. maliformis, P. foetida, P. nitida e P. quadrangularis, por apresentarem resistência a doenças ou a pragas, longevidade, maior adaptação a condições climáticas adversas, período de florescimento ampliado, maior concentração de componentes químicos interessantes para a indústria farmacêutica e outras potencialidades, têm grande potencial para o melhoramento genético do maracujazeiro (FALEIRO et al., 2005).

A produção do maracujá brasileiro é bastante variável, a qual é função do potencial genético da planta e das condições ambientais. No Brasil, considerando o potencial da cultura, torna-se necessário o investimento em cultivares mais produtivos e com qualidade desejável (MELETTI \& BRUCKNER, 2001), além da utilização de melhores tecnologias de produção. 
O melhoramento genético usa a hibridação para a transferência de genes de resistência de um material resistente para um material suscetível. As espécies silvestres têm importante papel nesses programas de melhoramento porque, de modo geral, elas apresentam genes de resistência. Um dos problemas que o melhorista enfrenta nesse tipo de programa é a incompatibilidade entre espécies. Para que a obtenção do híbrido interespecífico seja bemsucedida, é necessário que as espécies a serem combinadas apresentem homologia cromossômica garantindo, assim, a viabilidade do híbrido. Portanto, o conhecimento das relações genômicas é necessário para o sucesso de um programa de hibridação.

De acordo com FALEIRO et al. (2005), a caracterização e a exploração da variabilidade genética das espécies de Passiflora podem revelar fontes de resistência ou tolerância de grande valor para o controle de doenças no campo ou utilização em programas de melhoramento genético.

Os trabalhos de melhoramento genético do maracujazeiro no Brasil ainda são recentes. As primeiras cultivares de maracujá tornaram-se disponíveis somente a partir de 1998, mas já representam avanço considerável em produtividade e qualidade de frutos (BRUCKNER et al., 2002).

\subsection{MELHORAMENTO VISANDO À RESISTÊNCIA ÀS DOENÇAS DO MARACUJAZEIRO}

A pesquisa tem sido fundamental para a seleção de genótipos de maracujá-azedo e maracujá-doce que sejam mais produtivos e resistentes a doenças. Uma das alternativas para essa seleção é fazer o uso da hibridação interespecífica, ou seja, cruzamentos convencionais de seleção ou cultivares comerciais com espécies silvestres, que geralmente apresentam resistência a doenças. Assim, é fundamental conhecer as características agronômicas, físicas e químicas das espécies nativas utilizadas nos cruzamentos (BRAGA et al., 2005).

O melhoramento genético visa solucionar problemas, principalmente referentes a doenças, fazendo uso da hibridação para a transferência de genes de resistência de um material resistente para um material suscetível. De modo geral, as espécies silvestres são importantes aos programas de melhoramento, pois apresentam genes de resistência a fitopatógenos (JUNQUEIRA et al., 2005).

Os autores MENEZES et al. (1994); OLIVEIRA et al. (1994b); FISCHER (2003) e MELETTI \& BRUCKNER (2001) relataram que as passifloras silvestres: Passiflora caerulea L., P. nitida Kunth, P. laurifolia L., alguns acessos de P. suberosa L., P. alata, P. coccinea, 
P. gibertii N.E. Br. e $P$. setacea são resistentes à morte precoce e a outras doenças causadas por patógenos de solo.

Espécies silvestres de maracujá espontâneas no cerrado são alternativas para a ampliação da base genética da resistência a diversas doenças, que podem ser combinadas com características de produtividade e qualidade de frutos em programas de melhoramento genético. Em vista disso, programas de melhoramento genético têm sido conduzidos visando à obtenção de variedades mais produtivas e resistentes a doenças, por meio da hibridação sexual entre as espécies cultivadas e espécies silvestres (BARBOSA, 1998; FALEIRO et al., 2005b; JUNQUEIRA et al., 2005). Ainda sobre esse aspecto, foi verificado por PAULA (2006) que as espécies comerciais, $P$. setacea, $P$. odontophylla, $P$. edulis nativo e o hibrido $P$. coccinea $\mathrm{x} P$. setaceae se comportaram como resistentes a $M$. incognita. Também verificou que $M$. incognita e $M$. javanica de maneira geral reduziram o desenvolvimento vegetativo das plantas das espécies de Passiflora, exceto para alguns casos, que $M$. javanica estimulou o desenvolvimento de plantas. Sendo tais informações úteis aos programas de melhoramento genético que buscam características agronômicas desejáveis, em especial voltadas para obtenção de material resistente a doenças.

Quanto às espécies silvestres, OLIVEIRA et al., (1994) trabalhando com inoculações artificiais de Colletotrichum gloeosporioides, verificaram que P. nítida mostrou-se imune ao fungo. P. edulis Sims f. flavicarpa, P. giberti, P. cincinnata, P. mollisima, P. caerulea, P. setacea, $P$. serrato digitata, $P$. coccinea, $P$. edulis vs. $P$. setacea, $P$. edulis vs. $P$. alata foram suscetíveis, enquanto $P$. edulis Sims acesso "Serra do Mar, Santos - SP” apresentou maior tolerância inicial. OLIVEIRA \& RUGGIEIRO (1998) citam as espécies $P$. giberti, $P$. maliformis, $P$. cincinnata, $P$. laurifolia, $P$. caerulea e $P$. setacea como promissoras fontes de resistência à bacteriose e as espécies $P$. edulis, $P$. laurifolia, $P$. setacea, $P$. giberti e $P$. alata à verrugose.

LEITE JR. (2002) relatou $P$. cincinata, $P$. mollissima e $P$. foetida como resistentes à bacteriose, $P$. maliformis como altamente resistente e $P$. alata e P. quadrangulares como altamente suscetíveis. Tais fatos indicam haver variabilidade no germoplasma de Passiflora spp., o que possibilita a obtenção de materiais comerciais de maracujazeiro com resistência a doenças.

No Distrito Federal, quanto ao uso de espécies selvagens como fonte de resistência à bacteriose, $P$. coccinea e seu híbrido $\mathrm{F} 1$ com $P$. edulis f. flavicarpa comercial não exibiram sintomas, mas os híbridos RC1, RC2 e RC3 para P. edulis f. flavicarpa foram altamente 
suscetíveis. As plantas de $P$. caerulea, $P$. giberti, $P$. mucronata, $P$. actinia e de alguns acessos de $P$. nitida e P. laurifolia também não mostraram sintomas. Por outro lado, P. amethystina, $P$. cincinata, $P$. quadrangulares e $P$. alata selvagens mostraram-se altamente suscetíveis para os isolados da região (JUNQUEIRA et al., 2005).

\subsection{MARCADORES MOLECULARES}

O princípio da utilização dos marcadores moleculares é baseado no dogma central da Biologia Molecular e na pressuposição de que diferenças genéticas no DNA significam, na maioria das vezes, diferenças fenotípicas. Suas vantagens são: obtenção de um número praticamente ilimitado de polimorfismos genéticos; identificação direta do genótipo sem influência do ambiente; possibilidade de detecção de tais polimorfismos em qualquer estádio de desenvolvimento da planta ou a partir de cultura de células ou tecidos. Ainda, há possibilidade de gerar maior número de informação genética por loco no caso de marcadores co-dominantes (FALEIRO, 2007).

Os marcadores moleculares de DNA têm contribuído substancialmente para dar suporte aos estudos de genética de populações de diversas espécies e tendem, pouco a pouco, a ser usados para assistir aos procedimentos de seleção e melhoramento. Por intermédio deles, é possível analisar a variabilidade genética, identificar genótipos ou genes específicos e detectar possíveis associações entre os marcadores e características fenotípicas (VIEIRA et al., 2005).

Marcadores moleculares são utilizados frequentemente no estudo de diversidade da variabilidade genética do maracujá, através da técnica de RAPD por ser uma metodologia mais simples e relativamente mais barata, tem sido intensamente usada pelos diversos laboratórios, em diferentes culturas, para as mais variadas finalidades. A técnica é capaz de detectar variações diretamente no DNA, e isso têm sido intensamente utilizados para diferentes estudos genéticos de diversas cultivares, incluindo importantes trabalhos sobre a variabilidade genética do maracujazeiro (FALEIRO et al., 2005b) e na identificação rápida de seleções interespecíficas provenientes ou não de cruzamentos controlados, além disso, a técnica apresenta uma grande capacidade de acessar as informações do genoma da espécie, pela facilidade e rapidez de execução, e pela eficiência e confiabilidade dos resultados (FALEIRO, 2007; VIANA et al., 2003; BELLON, 2008; VILELA, 2013).

Fragmentos de DNA são amplificados no decorrer da técnica de RAPD, e para isso utiliza-se um único primer. Para que ocorra a amplificação de um fragmento de RAPD no genoma analisado, duas sequências de DNA complementares ao primer arbitrário devem estar adjacentes e em orientação oposta, de forma a permitir a amplificação de um segmento de 
DNA pelo DNA polimerase (FERREIRA \& GRATTAPAGLIA, 1998). A presença ou ausência de bandas é determinada pelo polimorfismo e é resultante da diferença do local de anelamento do primer. As bandas são herdadas de maneira Mendeliana e, portanto, são úteis como marcadores moleculares para caracteres qualitativos e quantitativos.

Sendo assim, não é necessário conhecimento prévio das sequências de nucleotídeos da região alvo. Por isso, os marcadores moleculares RAPD podem ser obtidos para qualquer espécie, mesmo aquelas ainda pouco estudadas (FERREIRA \& GRATTAPAGLIA, 1998).

Os marcadores RAPD baseiam-se no uso de iniciadores arbitrários que são utilizados na amplificação de DNA via PCR.

A tecnologia da reação em cadeia de polimerase (PCR - Polymerase Chain Reaction) é uma técnica poderosa para estudos genético-moleculares envolvendo grande número de indivíduos de qualquer organismo vivo devido à sua facilidade, versatilidade e sensibilidade. Muitos métodos tradicionais de clonagem, sequenciamento e análise de polimorfismo de DNA foram acelerados ou substituídos pela técnica de PCR (FERREIRA \& GRATTAPAGLIA, 1998).

A PCR envolve a síntese enzimática in vitro de milhões de cópias de um segmento específico de DNA pela enzima polimerase. A reação de PCR se baseia no anelamento e extensão enzimática de um par de oligonucleotídeos (pequenas moléculas de DNA de fita simples) utilizados como iniciadores primers, que delimitam a sequência de DNA de fita dupla alvo da amplificação. Esses primers são sintetizados artificialmente de maneira que suas sequências de nucleotídeos sejam complementares a sequências específicas que flanqueiam a região alvo (FERREIRA \& GRATTAPAGLIA, 1998).

Um ciclo da PCR envolve três etapas (desnaturação, anelamento e extensão). A fita dupla de DNA alvo é desnaturada através da elevação de temperatura para 92 a $95^{\circ} \mathrm{C}$. Na etapa de anelamento, a temperatura é rapidamente reduzida para 35 a $60^{\circ} \mathrm{C}$, dependendo essencialmente do tamanho e sequência do primer utilizado, permitindo a hibridização DNADNA de cada primer com as sequências complementares que flanqueiam a região alvo. Em seguida, a temperatura é elevada para $72^{\circ} \mathrm{C}$ para que a enzima polimerase realize a extensão a partir de cada terminal 3' dos primers. Essa extensão envolve a adição de nucleotídeos utilizando como molde a sequência-alvo, de maneira que uma cópia dessa sequência seja feita no processo. Esse ciclo é repetido por algumas dezenas de vezes. Uma vez que a quantidade de DNA da sequência-alvo dobra a cada ciclo, a amplificação segue uma progressão 
geométrica de maneira que, depois de apenas 20 ciclos, seja produzida mais de um milhão de vezes a quantidade inicial da sequência alvo (FERREIRA \& GRATTAPAGLIA, 1998).

Para a análise dos marcadores genético-moleculares, o primeiro passo é a codificação dos fragmentos moleculares em dados binários (no caso de marcadores dominantes) ou dados de coincidência alélica (no caso de marcadores co-dominantes). Os dados para marcadores dominantes, geralmente, são codificados como 1 (presença de marcador) e 0 (ausência do marcador). Os dados para marcadores co-dominantes geralmente são codificados como zero (ausência de alelos comuns no loco), 1/2 (um alelo comum no loco) e 1 (os dois alelos comuns no loco). No caso de marcadores baseados na sequência de nucleotídeos, a codificação é a própria sequência de nucleotídeos, representada pelas quatro diferentes bases nitrogenadas do DNA (FALEIRO, 2007).

O segundo passo é utilizar os dados codificados para a estimativa de índices de similaridade ou de distância genética entre cada par de acessos. Geralmente, os coeficientes de correlação entre os diferentes índices são muito altos (CORRÊA et al., 1999), embora existam algumas diferenças importantes entre elas (DIAS, 1998). No caso de marcadores baseados na sequência de nucleotídeos de determinado fragmento de DNA, os índices de similaridade ou de distância são calculados com base na homologia de sequência (KIMURA, 1980).

Com base nos índices, estabelece-se uma matriz de similaridade ou de distâncias entre os acessos a qual vai servir de base para as análises de agrupamento e de dispersão dos acessos. As análises de agrupamento geralmente são baseadas em métodos hierárquicos que podem utilizar diferentes critérios de agrupamento: vizinho mais próximo ("single linkage"), vizinho mais distante ("complete linkage") e baseado na média das distâncias ("unweighted pairgroup method using arithmetic average"). No caso da análise de dispersão dos acessos, o método mais utilizado é aquele baseado em escalas multidimensionais por meio das coordenadas principais. Esse método tem sido denominado análise de coordenadas principais ("principal coordinate analysis" - PCDA) (GOWER,1966) que também é discutido por DIAS (1998).

Existem vários softwares disponíveis para a análise de marcadores moleculares, entre eles o GENES (CRUZ, 1997), o STATISTICA (STATSOFT, 1999), o NTSYS (ROHLF, 1992), o GQMOL (CRUZ \& SCHUSTER, 2000), o SPSS (NORUSIS, 1993) e o SAS (SAS INSTITUTE, 1989). Eles são de grande importância para a realização das análises, principalmente, quando vários acessos são analisados simultaneamente (FALEIRO, 2007). 
Esses vários softwares diferem-se nos procedimentos e na abrangência das análises, nos formatos dos arquivos utilizados como entrada de dados, na robustez, linguagem de programação e na qualidade gráfica dos resultados ou saída dos dados (FALEIRO, 2007).

A utilização de marcadores moleculares como uma ferramenta de seleção em culturas perenes é uma tecnologia atraente, tendo em vista o tempo necessário para completar uma geração de melhoramento dessas espécies. A perspectiva de tornar mais eficiente a seleção precoce, e com isso aumentar o ganho genético por unidade de tempo, faz com que o melhoramento de espécies florestais e frutíferas seja a área onde o uso efetivo desta tecnologia tende a ter as melhores perspectivas de sucesso (FERREIRA \& GRATTAPAGLIA, 1998).

Os programas de melhoramento genético têm sido conduzidos visando à obtenção de variedades mais produtivas e resistentes a doenças, por meio da hibridação sexual entre as espécies cultivadas e espécies selvagens. O estudo da diversidade genética de potenciais genitores é uma etapa básica e de fundamental importância para o sucesso de programas de melhoramento genético. Por isso, o desenvolvimento de cultivares com resistência a doenças é uma alternativa interessante, pois envolve medidas de segurança para o trabalhador agrícola e o consumidor, preservação do ambiente, redução de custos de produção, qualidade mercadológica, entre outros, sendo uma demanda atual para as pesquisas em maracujazeiro (FALEIRO et al., 2005a).

Com o advento dos marcadores moleculares é possível analisar a variabilidade genética, identificar genótipos ou genes específicos e com isso aumentar a eficiência dos programas de conservação e uso dos recursos genéticos vegetais. Além disso, por meio dos marcadores moleculares pode-se obter um número ilimitado de polimorfismos genéticos em qualquer estádio da planta ou a partir de cultura de células ou tecidos (FALEIRO, 2007). 


\section{REFERÊNCIAS BIBLIOGRÁFICAS}

AGRIOS, G. N. Plant disease caused by nematodes. In: AGRIOS, G. N. Plant Pathology. San Diego: Academic Press, Inc., p.565-597. 1997.

ARÊDES, A.F.; PEREIRA, M.W.G.; GOMES, M.F.M.; RUFINO, J.L.S. Análise econômica da irrigação na cultura do maracujá. Revista de Economia da Universidade Estadual de Goiás, Anápolis, v.5, n.1, p.66-86. 2009.

AINSWORTH, G.C. Ainsworth and Bisby's dictionary of the fungi. $6^{\text {th }}$ ed. Kew, England, Commonwealth Mycological Institute, 1971.

AKAMINE, E.K.; GIROLAMI, G. Pollination and fruit set in the yellow passion fruit. Havai, EUA: University of Hawaii, 44p. (University Hawaii. Technical Bulletin, 39).1959.

AMORIM, L. Avaliação de Doenças. In: BERGAMIN FILHO, A.; KIMATI, H.; AMORIM, L. (ed.) Manual de Fitopatologia: Princípios e conceitos. São Paulo, Editora Agronômica Ceres Ltda., v.1, cap.32, p.645-671. 1995.

ANDRIGUETO, J.R.; NASSER, L.C.B.; TEIXEIRA, J.M.A.; KOSOSKI, A.R. Produção Integrada de Frutas: conceito, histórico e a evolução para o Sistema Agropecuário de Produção Integrada - SAPI. Brasília/DF - Brasil, 2006.

BARBOSA, C.J. \& SANTOS FILHO, H.P. Doenças causadas por vírus e similares. In: Maracujá: fitossanidade. Frutas do Brasil. Brasília: Embrapa, 2003.

BARBOSA, L. V. Citologia de híbridos somáticos de Passiflora spp. obtidos por fusão de protoplastos. Tese de Doutorado. São Paulo SP. Universidade de São Paulo. 1998.

BELLON, G. Variabilidade genética de acessos de maracujazeiro-doce caracterizada por marcadores RAPD e avaliação da resistência à bacteriose e à virose do endurecimento dos frutos. In: SIMPÓSIO NACIONAL CERRADO, 9.; SIMPÓSIO INTERNACIONAL SAVANAS TROPICAIS, 2., 2008, Brasília, DF. Desafios e estratégias para o equilíbrio entre sociedade, agronegócio e recursos naturais: anais... Planaltina, DF: Embrapa Cerrados, 1 CDROM. 2008.

BERGAMIN FILHO, A.; AMORIM, L. Doenças de plantas tropicais: epidemiologia e controle econômico. São Paulo: Ceres, 299p. 1996. 
- Curvas de progresso da doença. In: BERGAMIN FILHO, A.; KIMATI, H.; AMORIN, A. Manual de fitopatologia. 3.ed. São Paulo: Agronômica Ceres, v.1, p.602-625. 1995.

BRAGA, M.F.; BATISTA, A.D.; JUNQUEIRA, N.T.V.; JUNQUEIRA, K.P.; VAZ, C.F.; SANTOS, E.C. \& SANTOS, F.C. Características agronômicas, físicas e químicas de maracujá-alho (Passiflora tenuifila Killip.) cultivado no Distrito Federal. In: FALEIRO, F.G.; JUNQUEIRA, N.T.V.; BRAGA, M.F.; PINTO, A.C.Q; SOUSA, E.S. IV Reunião técnica de pesquisas em maracujazeiro. Planaltina, DF: Embrapa Cerrados, 86-90p. 2005.

BRAZ, A.S.K.; SANTANA, E.N.; ZAMBOLIN, E.M.; OTONI, W.C.; COSTA, A.F.; ZERBINI, F.M. Molecular characterization of two isolates of South African passiflora potyvirus infecting Passion fruit in Brazil. Fitopatologia Brasileira, Brasília, v.23, 313p. 1998.

BRUCKNER, C.H.; MELETT, L.M.M.; OTONI, W.C.; JUNIOR, F.M.Z. Maracujazeiro. In: BRUCKNER, C.H. Melhoramento de Fruteiras Tropicais. Viçosa: UFV, p.373-409. 2002.

. OTONI, W.C. Hibridação em maracujá. In: BORÉM, A. (Ed.) Hibridação artificial de plantas. Viçosa: UFV, p.379-399. 1999.

CARNE, W. M. Additions to the plant disease of South Western Australia. J. Proc. R. Soc. West. Australia v.14, p.24-28. 1927.

CHAGAS, C.M.; KITAJIMA, E.W. \& LIN, M.T. Grave moléstia em maracujá amarelo (Passiflora edulis f. flavicarpa Deg.) no Estado da Bahia, causada por um isolado do vírus do “woodiness”. Fitopatologia Brasileira v.6, p.259-268. 1981.

COBB, N.A. Woodiness of the passionfruit. Agric. Gaz. N.S.W.12: 407-418, 1991. In: KITAJIMA , E. W.; CHAGAS, C.M. \& CRESTANI, O.A. Enfermidades de etiologia viral e associadas a organismos do tipo micoplasma em maracujazeiros no Brasil. Fitopatologia Brasileira, v.11, p.409-432. 1986.

CORRÊA, R.X.; ABDELNOOR, R.V.; FALEIRO, F.G.; CRUZ, C.D.; MOREIRA, M.A. \& BARROS, E.G. Genetic distances in soybean based on RAPD markers. Bragantia, Campinas, v.58, p.15-22.1999.

CRUZ, C.D. \& SCHUSTER, I. Programa GQMOL: genética quantitativa e molecular. Viçosa: Universidade Federal de Viçosa, 2000. Disponível em: < http://www.ufv.br./ dbg/gqmol/gqmol.htp>. Acesso em: 13 maio. 2008. 
Programa Genes: aplicativo computacional em genética e estatística. Viçosa: UFV. 442p. 1997.

CUNHA, M.A.P. da; BARBOSA, L.V. \& JUNQUEIRA, N.T.V. Aspectos botânicos. In: LIMA, A. de A. (Ed.). Maracujá produção: aspectos técnicos. Embrapa Mandioca e Fruticultura, Cruz das Almas. Brasília: Embrapa Informação Tecnológica (Frutas do Brasil, 15). p.15-24.2002.

\& FARIA, G.A. Botânica. In: LIMA, A.A \& CUNHA, M.A.P. Maracujá: produção e qualidade na passicultura. Cruz das Almas: Embrapa Mandioca e Fruticultura. p.13-36. 2004.

DIAS, S.C. Morte precoce do maracujazeiro amarelo (Passiflora edulis f. flavicarpa) causada por patógenos que afetam a parte aérea da planta. 1990. 137f. Dissertação (Mestrado em Fitopatologia) - Universidade de Brasília, 1990.

DIAS, M.S.C. Principais doenças fúngicas e bacterianas do maracujazeiro. Informe Agropecuário, v. 21, p.34-38. 2000.

DIAS, S.C.; TAKATSU, A. Ocorrência de bacteriose do maracujazeiro (Passiflora sp.) causada por Xanthomonas campestris pv. Passiflorae no Distrito Federal. Fitopatologia Brasileira, Brasília, v. 12, n. 2, 140p. 1987.

Di PIERO, R.M.; REZENDE, J.A.M; YUKI, V.A.; PASCHOLATI, S.F.; DELFHINO, M.A. Transmissão do Passion Fruit Woodiness Virus por Aphis gossypii (Glover) (Hemiptera: Aphididae) e Colonização de Maracujazeiro pelo Vetor. Neotropical Entomology, v. 35, n 1, p.139-149. (Nota Científica) 2006.

Dos ANJOS, J.R.N.; JUNQUEIRA, N. T.V; CHARCHAR, M.J.A. Incidência e distribuição do vírus do endurecimento dos frutos do maracujazeiro no cerrado do Brasil Central. Documento n 30, Embrapa Cerrados, Planaltina-DF, 2001.

DURIGAN, J.F. Colheita e conservação pós-colheita. In: SIMPÓSIO BRASILEIRO SOBRE A CULTURA DO MARACUJAZEIRO, 5, 1998, Jaboticabal. Anais... Jaboticabal: FUNEP, 388p. 1998.

SIGRIST, J. M. M.; ALVES, R. E.; FILGUEIRAS, H. A. C.; VIEIRA, G. Qualidade e tecnologia pós-colheita do maracujá. In: LIMA, A. de A.; CUNHA, M.A. P. (Org.). Maracujá: produção e qualidade na passicultura. Cruz das Almas: Embrapa Mandioca e Fruticultura, p.283-303. 2004. 
DYE, D.W.; BRADBURY, J.F.; GOTO, M.; HAYWARD, A.C.; LELLIOT, R.A.; SOHRO, M.N. International standards for naming pathovars of phytopathogenic bacteria and a list of pathovar names and pathotype stains. Review of Plant Pathology, v.59, n.4, p.153168. 1980.

FALEIRO, F.G.; JUNQUEIRA, N.T.V. \& BRAGA, M.F. Pesquisa e desenvolvimento do maracujá no Brasil. In: SILVA, A.G.; ALBUQUERQUE, A.C.S.; MANZANO, N.T.; SILVA, R.C. \& RUSSELL, N.C. (Eds.). Agricultura Tropical: Quatro Décadas de Inovações Tecnológicas, Institucionais e Políticas. 1 ed. Brasília: Embrapa, 2008.

Marcadores genético-moleculares aplicados a programas de conservação e uso de recursos genéticos. Planaltina, DF: Embrapa Cerrados, 102p. 2007.

JUNQUEIRA, N.T.V. \& BRAGA, M.F. Maracujá: demandas para a pesquisa. Planaltina, DF: Embrapa Cerrados, 54 p. 2006a.

JUNQUEIRA, N.T.V. \& BRAGA, M.F. Importância e avanços do prémelhoramento de Passiflora. In: Lopes, M.A.; FÁVEO, A.P.; FERREIRA, M.A.J.F. \& FALEIRO, G.F. (Org.). Curso Internacional de pré-melhoramento de plantas. 1ed. Brasília: Embrapa. p.138-142. 2006b.

JUNQUEIRA, N.T.V. \& BRAGA, M.F. Maracujá: germoplasma e melhoramento genético. In: FALEIRO, F.G., JUNQUEIRA, N.T.V. \& BRAGA, M.F. (Eds.). Germoplasma e melhoramento genético do maracujazeiro - desafios da pesquisa. Planaltina, DF: Embrapa Cerrados. p.187-210. 2005a.

. JUNQUEIRA, N.T.V. \& BRAGA, M.F. Maracujá: potencial de espécies silvestres de maracujazeiro como fonte de resistência a doenças. In: FALEIRO, F.G., JUNQUEIRA, N.T.V. \& BRAGA, M.F. (Eds.). Germoplasma e melhoramento genético do maracujazeiro desafios da pesquisa. Planaltina, DF: Embrapa Cerrados. p.81-107. 2005 b.

JUnQueIRA, N. T. V.; FÁVERO, A. P.; LOPES, M. A. Pré-melhoramento de plantas: experiências de sucesso. In: FALEIRO, F. G.; NETO, A. L. F.; JÚNIOR, W. Q. R. Pré-melhoramento, melhoramento e pós-melhoramento: estratégias e desafios. Planaltina, DF: Embrapa Cerrados; Brasília DF: Embrapa Informação Tecnológica, 2008.

JUNQUEIRA, N.T.V.; BRAGA, M.F. Pesquisa e desenvolvimento do maracujá. In: ALBUQUERQUE, A.C.S.; SILVA, R.C.; (Eds.). Agricultura Tropical: Quatro Décadas de Inovações Tecnológicas, Institucionais e Políticas. 1 ed. Brasília: Embrapa. p.411-416. 2008. 
FALCONNER, P.; TITTOTO, K.; PARENTE, T.V.; JUNQUEIRA, N.T.V.; MANICA, I. Caracterização físico-química de frutos de seis cultivares de maracujá azedo (Passiflora spp.) produzidos no Distrito Federal. In: RUGGIERO, C. (ed.). Maracujá, do plantio à colheita. Jaboticabal: FCAV/UNESP/SBF. p.365-367. 1998.

FANCELLI, M \& LIMA, A.A. Insetos - Praga do maracujazeiro. In: LIMA, A.A \& CUNHA, M.A.P (Eds.). Maracujá: produção e qualidade na passicultura. Cruz das Almas: Embrapa Mandioca e Fruticultura. p.179-210. 2004.

FERREIRA, G. Propagação do maracujazeiro. Informe Agropecuário, Belo Horizonte, MG, v. 21, n. 206, p.18-24. 2000.

FERREIRA, M.E. \& GRATTAPAGLIA, D. Introdução ao uso de marcadores moleculares em análise genética. $3^{\text {a }}$ ed. Brasília: Embrapa-Cenargen, 220p. 1998.

FOLEGATTI, M.I.S. \& MATSUURA, F.C.A.U. Produtos. Maracujá: pós-colheita. Brasília: Embrapa Informação Tecnológica, 51p. (Frutas do Brasil, 23). 2001.

FISCHER, I.H.; KIMATI, H. \& REZENDE, J.A.M. Doenças do Maracujazeiro. In: KIMATI, H.; AMORIM, L.; REZENDE, J.A.M.; BERGAMIN FILHO, A.; CAMARGO, L.E.A. (Ed.) Manual de Fitopatologia. v2. 4.ed. São Paulo: Agronômica Ceres, p.467-474. 2005.

FREIRE, F.C.O. Nematoides de Fruteiras Tropicais de Interesse Agroindustrial. In: FREIRE, F.C.O.; CARDOSO, J.E. \& VIANA, F.M.P. Doenças de fruteiras tropicais de interesse agroindustrial. Brasília: EMBRAPA Informação Tecnológica, p.533-537. 2003.

FRUTAS, www.embrapa.br/uc/dtc/frutas.htm 30/01/13 1p.

FRUTAS TROPICAIS, www.brasil-in-action.gov.br/fatores/frutas/index.htm 30/01/13 3p.

GOES, A. Doenças fúngicas da parte aérea da cultura do maracujá. In: Simpósio Brasileiro sobre a cultura do maracujazeiro. Jaboticabal. Anais... Jaboticabal: FUNEP, p. 208216. 1998.

GONCALVES, E. R. \& ROSATO, Y. B. Genotypic characterization of Xanthomonad strains isolated from passion fruit plants (Passiflora spp.) and their relatedness to different Xanthomonas species. International Journal of Systematic and Evolutionary Microbiology v. 50, p. 811-821. 2000. 
GONÇALVES, G.M.; VIANA, A.P.; BEZERRA NETO, F.V.; PEREIRA, M.G.; PEREIRA, T.N.S. Seleção e herdabilidade na predição de ganhos genéticos em maracujá-amarelo. Pesquisa Agropecuária Brasileira, v.42, p.193-198. 2007.

GOWER, J.C. Some distance properties of latent root and vector methods used in multivariate analysis. Biometrika, London, v.53, p.325-338. 1966.

HARDIN, L. C. Floral biology and breeding system of the yellow passionfruit, Passiflora edulis f. flavicarpa. Proceedings of the Interamerican Society for Tropical Horticulture, v. 30, p.35-44, 1986.

HOEHNE, F. C. Botânica e agricultura no Brasil (Século XVI). São Paulo: Companhia. 1937.

IBGE. Banco de dados agregados. Disponível em: http://www.sidra.ibge.gov.br/bda. Acesso em: 18, outubro, 2013.

- Banco de Dados agregados Maracujá. Disponível em: http://www.sidra.ibge.gov.br/bda/tabela/protabl.asp?c=106\&z=t \&o=11\&i=P. Acesso em: 11, janeiro, 2014.

INSTITUTO BRASILEIRO DE GEOGRARIA E ESTATÍSTICA. Maracujá: área plantada e quantidade produzida. Brasília: IBGE, 2010. (Produção Agrícola Municipal em 2009). Disponível em: http://www.sidra.ibge.gov.br/bda/tabela/protabl. Acesso em: fevereiro de 2013.

INCH, A.J. Passionfruit diseases. Queensland Agricultural Journal, p. 479-484, set/out. 1978.

ITI Tropicals. Disponível em: www.passionfruitjuice.com. Acesso em fevereiro de 2008.

JEFFRIES, P.; DODD, J.C.; JEGER \& PUMBLEY, R.A. The biology and control of Colletotrichum sp. on tropical fruit crops. Plant Pathology.v.39, p.343-366. 1990.

JUNQUEIRA, N.T.V.; BRAGA, M.F.; FALEIRO, F.G.; PEIXOTO, J.R. \& BERNACCI,

L.C. Potencial de espécies silvestres de maracujazeiro como fonte de resistência a doenças. In: FALEIRO, F.G., JUNQUEIRA, N.T.V. \& BRAGA, M.F. (Eds.). Maracujá: germoplasma e melhoramento genético do maracujazeiro - desafios da pesquisa. Planaltina, DF: Embrapa Cerrados. p. 341-358. 2005. 
BRAGA, M.F.; FALEIRO, F.G.; PEIXOTO, J.R.; BERNATTI, L.C. Potencial de espécies silvestres de maracujazeiro como fonte de resistência a doenças. In: FALEIRO, F.G.; JUNQUEIRA, N.T.V.; BRAGA, M.F. (Ed.) Maracujá germoplasma e melhoramento genético. Brasília, DF: Embrapa Cerrados, p.80-108. 2005.

. SHARMA R.D.; RITZINGER, C.H.S.P. Manejo da bacteriose e de nematóides em maracujazeiro (compact disc). In: SIMPÓSIO BRASILEIRO SOBRE A CULTURA DO MARACUJAZEIRO, 6., Campos dos Goytacazes, 2003. Palestras. Campos dos Goytacazes: Cluster Informática, 2003.

. ANJOS, J.R.N.; SILVA, A.P.O.; CHAVES, R.C.; GOMES, A.C. Reação às doenças e produtividade de onze cultivares de maracujá-azedo cultivadas sem agrotóxicos. Pesquisa Agropecuária Brasileira, v. 38, n. 8 p.1005-1010, 2003.

SHARMA, R.D.; JUNQUEIRA, K.P.; ANDRADE, L.R.M. Doenças constatadas na fase pós-colheita. In: SANTOS FILHO, H.P.; JUNQUEIRA N.T.V. (Ed.) Maracujá Fitossanidade. Brasília: Embrapa Informação Tecnológica, p. 32-36. 2003.

TEIXEIRA,R.V.R; ANJOS, J.R.N.; VERAS, M.C.M.; NASCIMENTO, A.C.; SHARMA, R.D. Controle das principais doenças do maracujazeiro no cerrado. Comunicado técnico, Embrapa Cerrados, n.8, p.1-5. 2000.

ANJOS，J.R.N.; SHARMA，R.D.; SANZONWICZ，C.; ANDRADE，L.R.M. Doenças do Maracujazeiro. In: Encontro de Fitopatologia, 3., 1999, Viçosa, MG. Doenças de fruteiras tropicais: palestras. Viçosa: UFV, p.83-115. 1999.

KAVATI, R. Florescimento e frutificação do maracujazeiro amarelo (Passiflora edulis f. flavicarpa). In: (ed) RUGGIERO, C. Maracujá - do plantio à colheita. Jaboticabal: Funep, p.107-129. 1998.

KIMURA, M.A. Simple method for estimating evolutionary rate of base substitutions through comparative studies of nucleotide sequences. Journal of Molecular Evolution v. 16; p.111-120.1980.

KIRK, P.M.; CANNON, P.F.; DAVID, J.C.; STALPERS, J. Ainsworth and Bisby's Dictionary of the Fungi.9th ed. CAB International, Wallingford, UK. 2001.

KITAJIMA, E.W. \& REZENDE, J.A.M. Enfermidade de etiologia viral e fitoplasmática. In: BRUCKENER. C. H. \& PICANÇO, C. Maracujá: Tecnologia de produção, pós-colheita, agroindústria e mercado. Porto Alegre: Cinco Continentes, 85-137p. 2001. 
CHAGAS, C.M. \& CRESTANI, O.A. Enfermidade de etiologia viral e associada a organismos do tipo micoplasma em maracujazeiro no Brasil. Fitopatologia Brasileira v.11, p.409-432. 1986.

KRANZ, J. Measuring plant disease. In: KRANZ, J.; ROTEM, J. (ed.) Experimental Techniques in Plant Disease Epidemiology, Heidelberg, Springer, p.35-50. 1988.

KUDO, A.S. Reação de genótipos de maracujazeiro azedo a Septoria passiflorae e a Cladosporium herbarum. 2004. 97f. Dissertação (Mestrado em Fitopatologia) - Universidade de Brasília, Brasília, DF, 2004.

KURODA, N. Avaliação do comportamento quanto à resistência de espécies e progênies de maracujazeiro a Xanthomonas campestris pv. passiflorae. Jaboticabal, SP: FCAV/UNESP, 45p. 1981.

LEÃO, R.M.K. Reação de progênies de maracujá-azedo ao vírus do endurecimento do fruto ("Passionfruit woodiness virus" - PWV) e à bactéria Xanthomonas campestris pv. Passiflorae. Brasília: Universidade de Brasília, 89p. (Dissertação de mestrado). 2001.

LEITÃO FILHO, H.F.; ARANHA, C. Botânica do Maracujazeiro. In: Simpósio da cultura do maracujá, Campinas. Sociedade Brasileira de Fruticultura, Campinas, SP. 1974.

LEITE JR., R.P. Bacteriose do maracujazeiro e estratégias para seu controle. In: REUNIÃO TÉCNICA DE PESQUISA EM MARACUJAZEIRO, 3., Viçosa, Anais, Viçosa: UFV/DFT, 2002. p.97-98. 2002.

LIBERATO, J.R.; COSTA, H.; VENTURA, J.A. Ocorrência de mancha de septória (Septoria spp.) em maracujazeiro amarelo (Passiflora edulis f. flavicarpa) no estado do Espírito Santo. Fitopatologia Brasileira, v. 20, p. 386, (suplemento).1995.

LIMA, A. de A.; BORGES, A.L. Solo e clima. p. 25-28. In: A. de A. Lima (ed.) Maracujá. Produção: Aspectos técnicos. Embrapa-SPI, Brasília, DF. 2002.

LIBERATO, J.R.; COSTA, H. Doenças fúngicas, bacterianas e fitonematoides. In: BRUCKNER, C.H.; PICANÇO, M.C. (Ed). Maracujá: tecnologia de produção, pós-colheita, agroindústria, mercado. Porto Alegre: Cinco continentes, p. 243-276. 2001. 
LOPES, S.C. Citogenética do maracujá, Passiflora spp. In: SÃO JOSÉ, A.R.; FERREIRA, F.R. \& VAZ, R.L. (Eds.) A cultura do maracujá no Brasil. Jaboticabal: FUNEP. p. 201-209. 1991.

MADDEN, L.V. Quantification of disease progression. Protection Ecology, 1980. v. 2, p. 159-176, 1980.

MANICA, I.; SÃO JOSÉ, A.R.; BRUCCKNER, C.H.; HOLFFMANN, M.O. Maracujá, temas selecionados (1): melhoramento, morte prematura, polinização e taxonomia. Porto Alegre: Cinco Continentes, 70 p. 1997.

MAPA - MINISTÉRIO DA AGRICULTURA PECUÁRIA E ABASTECIMENTO. O Setor Produtivo da Fruticultura. 2009. Disponível em: < http://www.agricultura .gov.br/> Acesso em: 20 Nov 2012.

MARTIN, F. W. \& NAKASONE, H. Y. The edible species of Passiflora. Economic Botany v. 24, p. 43-333. 1970.

Y. The edible species of passiflora. Economic Botany, Bronx, v.24, n.3, p.333343.1970 .

MATTA, F.P. Mapeamento de QLR para Xanthomonas axonopodis pv. Passiflorae em maracujá-azedo (Passiflora edulis Sims f. flavicarpa Deg.) 2005. 230f. Tese (Doutorado em Agronomia) - Escola Superior de Agricultura "Luiz de Queiroz", Universidade de São Paulo, 2005.

MELETTI, L.M.M. \& MAIA, M.L. Maracujá: produção e comercialização. Boletim técnico, 181. Campinas, Instituto Agronômico, 64p. 1999.

. Maracujazeiro (Passiflora edulis Sims.) In: MELETTI, L. M. M. (Ed.) Propagação de frutíferas tropicais. Guaíba, RS: Agropecuária Ltda. p.186-204. 2000.

. SANTOS, R.R. dos.; MINAMI, K. Melhoramento do maracujazeiro-amarelo: Obtenção do ‘Composto IAC-27’. Scientia Agrícola, v. 56, n. 3, p. 491-498, 2000.

\& BRUCKNER, C.H. Melhoramento genético. In: BRUCKNER, C. H. \& PICANÇO,

M. C. (Eds.). Maracujá: tecnologia de produção, pós-colheita, agroindústria, Mercado. Porto Alegre: Cinco Continentes. p. 345-385. 2001.

SOARES-SCOTT, M.D.; BERNATTI, L.C.; PASSOS, I.R.S. Melhoramento genético do maracujá: passado e futuro. In: FALEIRO, F.G.; JUNQUEIRA, N.T.V.; BRAGA, M.F. 
(Ed.) Maracujá germoplasma e melhoramento genético. Brasília, DF: Embrapa Cerrados, p. 55-78. 2005.

MIRANDA, H.A. Incidência e severidade de Xanthomonas axonopodis pv. passiflorae, Colletotrichum gloeosporioides, Septoria passiflorae, Cladosporium herbarum e Passion Woodiness fruit virus em genótipos de maracujazeiro azedo cultivados no Distrito Federal. Brasília, 2004. 87f. Dissertação (Mestrado em Ciências Agrárias) - Faculdade de Agronomia e Medicina Veterinária, Universidade de Brasília, 2006.

MILNE, D. L. Nematode pests of miscellaneous sub-tropical crops. In: KEETCH, D. P. \& HEYS, J. (Eds.). Nematology in Southern Africa Science Bulletin v. 400, p.42-46.1982.

MIRANDA, J.F. Reação de variedades de maracujazeiro amarelo (Passiflora edulis Sims f. flavicarpa Deg.) a bacteriose causada por Xanthomonas campestris pv. passiflorae. 2004. 48 f. Dissertação (Mestrado em Agronomia). Escola Superior de Agricultura Luiz de Queiroz, Piracicaba, São Paulo, 2004.

MORAES, S.A. de Quantificação de doenças de plantas. Artigo em Hypertexto. Disponível em: <http://www.infobibos.com/Artigos/2007_1/doencas/index.htm>. Acesso em: $23 / 8 / 2012$

MORAES, M.C.; VIEIRA, M.L.C.; NOVAES, Q.S.; REZENDE, J.A.M. Susceptibilidade de Passiflora nitida ao Passion fruit woodiness virus. Fitopatologia Brasileira, v.27, 108p. 2002.

NAKATANI, A.K. Diversidade genética de Xanthomonas campestris pv. passifloraee sensibilidade a produtos químicos. 2001. 61 f. Dissertação (Mestrado). Escola Superior de Agricultura “Luiz de Queiroz”, Piracicaba, São Paulo, 2001.

NASCIMENTO, A.V.S.; SANTANA, E.N; BRAZ, A.S.K.; ALFENAS, P.F.; PIO-RIBEIRO, G.; ANDRADE, G.P.; CARVALHO, M.G. \& ZERBINI, F. MURILO. Cowpea aphid-borne mosaic virus (CABMV) is widespread in passionfruit in Brazil and causes passionfruit woodiness disease. Archives of Virology, Viena, v.161, p.21-34, 2006.

NASCIMENTO, A.C.; JUNQUEIRA, N.T.V.; PEIXOTO, J.R.; MANICA, I.; KOSOSK, R.M.; JUNQUEIRA, K.P. Comportamento de frutos de 10 genótipos de maracujazeiroazedo em relação à antracnose (Colletotrichum gloeosporioides ) e à verrugose (Cladosporium spp.) no Distrito Federal. In: CONGRESSO BRASILEIRO DE FRUTICULTURA, 16, Fortaleza, 2000. Resumos... Fortaleza: SBF, 473p. 2000. 
NASCIMENTO, W. O.; TOMÉ, A T.; OLIVEIRA, M. S. P.; MÜLLER, C. H.; CARVALHO, J.E.U. Seleção de progênies de maracujazeiro-amarelo (Passiflora edulis. f. flavicarpa) quanto à qualidade de frutos. Revista Brasileira de Fruticultura, v. 25, n. 1, p.186-188, 2003.

NORUSIS, M.J. SPSS for windows, advanced statistics, Release 6.0. Chicago: SPSS. 1993.

OLIVEIRA, J. C. de \& RUGGIERO, C. Aspectos sobre o melhoramento do maracujazeiro amarelo. In: RUGGIERO, C. (Org.). L SIMPÓSIO BRASILEIRO SOBRE A CULTURA DO MARACUJAZEIRO, 10-13 de fevereiro, 1998, Jaboticabal. Anais. Jaboticabal: Funep, 388p.1998.

NAKAMURA, K.; MAURO, A.O.; CENTURION, M.A.P.C. Aspectos gerais do melhoramento do maracujazeiro. In: SÃO JOSÉ, A.R. (Ed.) Maracujá: produção e mercado. Vitória da Conquista-BA: UESB-DFZ, p.27-28. 1994.

FERREIRA, F.R. Melhoramento genético do maracujazeiro. In: SÃO JOSÉ, A.R.; FERREIRA, F.R.; VAZ, R.L. A cultura do maracujá no Brasil. Jaboticabal: FUNEP, p. 211239. 1991.

. Melhoramento genético de Passiflora edulis Sims f. flavicarpa Deg. visando aumento de produtividade. 1980. 133 f. Tese Livre Docência. Jaboticabal, SP: UNESP, 1980.

PAULA, M.S. Diversidade genética e reação de Passiflora spp. a Meloidogyne incognitae a Meloidogyne javanica. (Dissertação de Mestrado). Brasília. Universidade de Brasília. 2006.

PEREIRA, F. A cultura do maracujá/ Embrapa Mandioca e Fruticultura Tropical - 3 ed. Rev. Amp.- Brasília, DF: Embrapa Informação Tecnológica, 124p.: (coleção plantar 51). 2006.

PEREIRA, A.L.G. Uma nova doença bacteriana do maracujá (Passiflora edulis, Sims) causada por Xanthomonas passiflorae sp. Arquivos do Instituto Biológico, v. 36, n.4, p.163174. 1969.

Contribuição ao estudo da mancha oleosa da folha de maracujá (Passiflorae edulis Sims) causada por Xanthomonas passiflorae sp. 1968. 91 f. (Dissertação de Mestrado). Escola Superior de Agricultura “Luiz de Queiroz”, Piracicaba, São Paulo, 1968. 
PINTO, P.H.D. Reação de genótipos de maracujá-azedo (Passiflora edulis f. flavicarpa Deg.) ao vírus Passionfruit Woodiness Virus (PWV) e ao fungo Septoria passiflorae. 2002. 62f. Dissertação (Mestrado em Ciências Agrárias) - Faculdade de Agronomia e Medicina Veterinária, Universidade de Brasília, 2002.

PIO-RIBEIRO, G. \& MARIANO, R.L.R.D. Doenças do maracujazeiro (Passiflora spp.). In: Manual de fitopatologia: doenças das plantas cultivadas. 3.ed. São Paulo: Editora Agronômica Ceres, v. 2, p.525-534. 1997.

PIO VIANA, A.; GONÇALVES, G.M. Genética quantitativa aplicada ao melhoramento genético do maracujazeiro. In: FALEIRO, F.G.; JUNQUEIRA, N.T.V.; BRAGA, M.F. (Ed.) Maracujá germoplasma e melhoramento genético. Brasília, DF: Embrapa Cerrados, p.243-274. 2005.

PEREIRA, T.N.S.; PEREIRA, M.G.; SOUZA, M.M.; MALDONADO, F.; AMARAL JÚNIOR, A.T. Diversidade entre genótipos de maracujazeiro amarelo (Passiflora edulis f. flavicarpa) e entre espécies de passifloras determinada por marcadores RAPD. Revista Brasileira de Fruticultura, Jaboticabal, v. 25, p.489-493. 2003.

PNP-FCP. Programa nacional de pesquisa de fruteiras de clima tropical. Relatório do Centro Nacional de Pesquisa de Mandioca e Fruticultura Tropical 1987-1990. EMBRAPA/CNPMF, Cruz das Almas, BA, 196p.1991.

PUNITHAlingaM, E. Septoria passifloricola. CMI Description of plant pathogenic fungi and bacteria, n. 670. 1980.

QUIRINO, T.R. Agricultura e meio ambiente: tendências. In: SILVEIRA, M.A.; VILELA, S.L.O. (Eds.). Globalização e sustentabilidade da agricultura. Jaguariúna: Embrapa-CNPMA, p. 109-138. (Documentos, 15). 1998.

RAMALHO, M.A.P.; FERREIRA, D.F.; OLIVEIRA, A.C. Experimentação em genética e melhoramento de plantas. Lavras, UFLA, 326p. 2000.

REINHARDT, D.H. Avanços tecnológicos na fruticultura tropical. Informativo SBF, Brasília, v.15, n.4, dezembro, 1996.

REZENDE, J.A.M. Doenças de vírus e micoplasma do maracujazeiro no Brasil. In: SÃO JOSÉ, A.R. (Ed.) Maracujá: produção e mercado. Vitória da Conquista: UESB p.116-125. 1994. 
RIZZI, L.C.; RABELLO, L.R.; MORZINI FILHO, W.; SAVAZAKI, E.T.; LAVATO, R. Cultura do maracujá azedo. Campinas, CATI, 54p. (Boletim Técnico, 235). 1998.

ROCHA, J.R.S.; OLIVEIRA, N.T. Controle biológico de Colletotrichum gloeosporioides, agente da antracnose do maracujazeiro (P. edulis) com Trichoderma koningii. Summa Phytopathologica, Jaboticabal. v. 24, n. 3/4. p.272-275, 1998.

ROHLF, F.J. NTSYS-pc - Numerical taxonomy and multivariate analysis system. Version 1.70. New York: Exeter Software, 1992.

RUGGIERO, C. Situação da cultura do maracujazeiro, no Brasil. Informe Agropecuário, Belo Horizonte, v. 21, n. 206, p.5-9, 2000.

. SÃO JOSÉ, A.R.; VOLPE, C.A.; OLIVEIRA, J.C.; DURINGAN, J.F.; BAUMGARTNER, J.G.; SILVA, J.R. da; NAKAMURA, K.; FERREIRA, M.E.; KAVATI, R.; PEREIRA, V. de P. Maracujá para exportação: aspectos técnicos da produção. Brasília, DF: EMBRAPA. SPI, Publicações Técnicas Frupex, v.19; 64p.1996.

SANTOS FILHO, H.P.; SANTOS, C.C.F. Doenças causadas por fungos. In: SANTOS FILHO, H.P.; JUNQUEIRA, N.T.V. Maracujá: fitossanidade. Brasília: Embrapa Informação Tecnológica, p. 12-21. (Embrapa Informação Tecnológica. Série Frutas do Brasil, 32). 2003.

SAS INSTITUTE INC. SAS/STAT user's guide. Version 6, 4 ed. SAS Institute, North Caroline, Cary. 1989.

SASSER, J. N. \& CARTER, C. C. Overview of the international Meloidogyne project (1975-1984). In: SASSER, J. N. \& CARTER, C. C. (Eds). An advanced treatise Meloidogyne: biology and control. Raleigh: North Caroline State University Graphics. v.l, p.19-24. 1985.

SÃO JOSÉ, R.R. Maracujá - Produção e comercialização. Vitória da Conquista - BA, DFZ / UESB, 260p. 1993.

SECRETARIA DE AGRICULTURA, IRRIGAÇÃO E REFORMA AGRÁRIA - SEAGRI. Cultura- maracujá. Salvador, [200-?]. Disponível em: <http://www.seagri.ba.gov.br/Maracuja.htm>. Acesso em: dez. 2013.

SIGRIST, J.M.M. In: SANTOS FILHO, H.P.; JUNQUEIRA, N.T.V. (Ed.) Maracujá: Fitossanidade. Brasília: Embrapa Informação Tecnológica, p. 20-31. 2003. 
SILVA, M. G. M. Seleção recorrente intrapopulacional no maracujazeiro amarelo: Alternativa de capitalização de ganhos genéticos. Ciência e Agrotecnologia, v. 33, n. 01, p. 170-176, 2009.

SHARMA, R. D.; RITZINGER, C. H. S. P.; JUNQUEIRA, N. T. V. \& ALVES, R; T. Reprodução e patogenicidade de Meloidogyne javanica no híbrido EC-2-0 de maracujáazedo. Planaltina, DF: Embrapa Cerrados, Boletim de Pesquisa e Desenvolvimento, v. 87. 12 p. 2003a.

RITZINGER, C. H. S. P.; JUNQUEIRA, N. T. V. \& GOMES, A. C. Reação de genótipos de maracujá-azedo aos nematóides Rotylenchullus reniformis. Planaltina, DF: Embrapa Cerrados, Boletim de Pesquisa e Desenvolvimento, 86. 14p. 2003 b.

\& LOOF, P. A. A. Nematodes associated with different plants at the Centro de Pesquisa do Cacau, Bahia. Revista Theobroma v.4, p. 38-43. 1972.

SHARMA, R.D.; JUNQUEIRA, N.T.V. \& GOMES, A.C. Reação de espécies de Passiflora a nematóide-das-galhas. In: REUNIÃO TÉCNICA DE PESQUISAS EM MARACUJAZIRO, 4, 2005. Planaltina, DF: EMBRAPA, Resumos...p.183-186.2005.

SKIPP, R.A.; BEEVER, R.E.; SHARROCK, K.R.; RIKKERINK, E.H.A. \& TEMPLETON, M.D. Colletotrichum. In: KOHMOTO, K.; SINGH, U.S. \& SINGH, R.P. (Ed.) Phatogenesis and host specificity in plant diseases. Oxford, Pergamon/Elsevier Sci. Ltd. public.vol.II, p. 119-242. 1995.

SOUZA, J.S.I. de \& MELETTI, L.M.M. Maracujá: espécies, variedades, cultivo. Piracicaba: FEALQ, 179p. 1997.

SOUZA, J.S.; CARDOSO, C.E.L.; FOLEGATTI, M.I.S.; MATSUURA, F.C.A.U. Maracujá: pós-colheita. Brasília: Embrapa Informação Tecnológica (Frutas do Brasil, 23) 51p. 2002.

SOUZA, P.M.; FERREIRA, V.R.; PONCIANO, N.J.; BRITO, M.N. Otimização econômica, sob condições de risco, para agricultores familiares das regiões norte e noroeste do Estado do Rio de Janeiro. Revista Pesquisa Operacional, Rio de Janeiro, v.28, n.1, p.123$139,2008$.

STATSOFT INC. Statistica for Windows [computer program manual] Tulsa, OK. StatSoft Inc. 2300 East 14th Street, Tulsa. 1999. 
SUTTON, B.C. The Coelomycetes. Commonwealth Mycological Institutte, Kew, Surrey, England, 696p. 1980.

The genus Glomerella and its anamorph. In: BAILEY J.A. \& JEGER M.J. (Ed.) Colletotrichum: biolody, pathology and control. England, CAB International Wallingford, p. 1-26. 1992.

SYDOW, H. Septoria passifloraenov.sp. In: Annales Mycologici, XXXVII (12):406-409. 1939.

TAYLOR, S.G.; BALTENSPERGER, D.D. \& DUNN, R.A.Interaction between six season legumes and three species of root-knot nematodes. Journal of Nematology v. 17, p. 367370. 1985.

TEIXERA, S. T. MERCADO EXPORTADOR - ANÁLISE PARA CULTURA DO MARACUJÁ. Unesp, 2005. Disponível em:

<http://www.todafruta.com.br/portal/icNoticiaAberta.asp?idNoticia=8543> Acesso em: $11 \mathrm{de}$ Julho de 2014.

TEIXEIRA, C.G. Cultura. In: TEXEIRA, C.G.; CASTRO, J.V.; TOCCHINI, R.P.; NISIDA, A.L.A.C.; HASHIZUME, T.; MEDINA, J.C.; TURATTI, J.M.; LEITE, R.S.S.F.; BLISKA, F.M.M.; GARCIA, A.E.B.C. (Ed). Maracujá: cultura, matéria-prima, processamento e aspectos econômicos. Campinas: Instituto Tecnologia de Alimentos, p. 1- 142. 1994.

TORRES FILHO, J. Doenças do maracujá (Passiflora edulis f.flavicarpa) na região da Ibiapaba, Ceará, Brasil. Fitopatologia Brasileira v. 10, p. 223. 1985.

TORRES, F.J.; PONTES, J. Estudo sobre o controle da bacteriose ou "morte precoce" (Xanthomonas campestris pv. passiflorae) do maracujá amarelo (Passiflora edulis f. flavicarpa). Fitopatologia Brasileira, v.19, n.1, p.34-38. 1994.

VALLINI, P.C.; RUGGIERO, C.; LAM-SANCHES, A.; FERREIRA, F.R. Studies on the flowering period of yellow passion fruit Passiflora edulis f. flavicarpa Deg. in the region of Jaboticabal, São Paulo. Acta Horticulturae, Wageningen, v.57, p.233-236. 1976.

VANDERPLANK, J. Passion flowers, 3.ed. Cambridge: The MIT Press, 224p. 2000.

VAN REGENMORTEL, M.H.V.; FAUQUET, C.M.; BISHOP, D.H.L.; CARSTENS, E.; ESTES, M.K.; LEMON, S.; MANILOFF, J.; MAYO, J.A.; McGEOCH, D.J.; PRINGLE, C.R.; WICKNER, R. (eds.). Virus taxonomy. Classification and nomenclature of 
viruses.Seventh report of the International Committee on the Taxonomy of Viruses. New York: Academic Press. 2000.

VIANA, F.M.P.; FREIRE, F.C.O.; CARDOSO, J.E.; VIDAL, J.C. Principais Doenças do Maracujazeiro na Região Nordeste e seu Controle. Comunicado Técnico, n. 86. Fortaleza, CE. Outubro, 2003.

. COSTA, A.F. Doenças do maracujazeiro. In: FREIRE, F.C.O.; CARDOSO, J.E.; VIANA, F.M.P. (Ed.) Doenças de fruteiras tropicais de interesse agroindustrial. Brasília: Embrapa Informação Tecnológica, p. 270-291. 2003.

VIEIRA, M.L.C.; OLIVEIRA, E.J.; MATTA, F.P.; PÁDUA, J.G.; MONTEIRO, M. Métodos biotecnológicos aplicados ao melhoramento genético de maracujá. In: FALEIRO, F.G., JUNQUEIRA, N.T.V. \& BRAGA, M.F.(Eds.). Maracujá: germoplasma e melhoramento genético do maracujazeiro - desafios da pesquisa. Planaltina, DF: Embrapa Cerrados. p.411453. 2005.

VILELA, P.; MARACUJÁ. Disponível em: <http://www.sebrae.com.br/setor/fruticultura/osetor/frutas-de-g-a zmaracuja/integra_bia?ident_unico=1042> Acesso: 22 de Julho de 2013.

WALLER, J.M. Colletotrichum diseases of perennial and other cash crops. In: BAILEY, J.A. \& JEGER, M.J. (Ed.) Colletotrichum: biology, pathology and control. England, CAB International Wallingford, p. 167-185. 1992.

WENDLAND, A. Avaliação de espécies de maracujazeiro (Passiflora spp.) à bacteriose e caracterização de Xanthomonas sp. pv. passiflorae. Londrina, 87p. Monografia (Graduação) - Universidade Estadual de Londrina. 1997.

YAMASHIRO, R. Principais doenças do maracujazeiro. In: Maracujá. Ribeirão Preto: Editora Legis Summa, p. 146-159. 1987.

YAMASHIRO, T.; CHAGAS, C.M. Ocorrência de grave moléstia virótica em maracujá amarelo no Estado da Bahia. In: CONGRESSO BRASILEIRO DE FRUTICULTURA, 5, 1979, Pelotas. Anais... Pelotas: SBF, p. 915-917. 1979. . PALAZZO, D.A.; GRISI JR, C. Doenças do maracujazeiro constatadas no Estado de São Paulo. In: Congresso Brasileiro de Fruticultura, Viçosa, MG. V. 2; p. 411-419. 1973. 
CAPITULO 1

RESISTÊNCIA DE PROGÊNIES DE MARACUJAZEIRO-AZEDO À BACTERIOSE EM CASA DE VEGETAÇÃO 


\section{RESUMO}

A Xanthomonas axonopodis pv. passiflorae é tida como a principal doença que afeta o maracujazeiro. Provocando perdas expressivas em cultivos comerciais, sendo de ocorrência severa sob condições de clima quente e úmido. O objetivo do experimento foi avaliar e selecionar progênies de maracujazeiro-azedo com resistência à bacteriose em condições de casa de vegetação. Para tanto, foi instalado experimento na Estação Experimental de Biologia pertencente à Universidade de Brasília (UnB). A semeadura foi realizada em bandejas de poliestireno expandido com setenta e duas células (120 ml/célula), utilizando substrato inerte vermiculita (Plantmax $\left.{ }^{\circledR}\right)$, com cinco sementes por célula. Com aproximadamente quarenta dias da semeadura, as mudas foram repicadas e transplantadas em bandejas de polietileno, uma muda por célula. Em seguida, foram feitas adubações de cobertura com ureia. O delineamento utilizado foi em blocos ao acaso, com quatro repetições, seis plantas úteis por parcela e vinte e quatro progênies, em cinco diferentes ensaios experimentais. Foi utilizado o arranjo experimental de parcelas subdivididas. As parcelas foram formadas por cinco épocas de avaliação e as subparcelas por vinte e quatro genótipos. As avaliações de incidência e severidade foram realizadas com intervalos de sete dias. Foi possível observar que a maioria das progênies foi altamente suscetível (AS) à bacteriose sendo que apenas três progênies de todo o experimento foram classificadas como suscetíveis (S). Valores elevados da herdabilidade e razão $\mathrm{CVg} / \mathrm{CVe}$ foram observados para AACPD. Esses resultados indicam condição favorável de seleção, em razão do baixo efeito ambiental.

Palavras-chave: passiflora edulis Sims, melhoramento genético, herdabilidade, incidência e severidade. 


\begin{abstract}
The Xanthomonas axonopodis pv. Passiflorae is considered one of the major diseases affecting passion fruit. It causes significant losses in cash crops, and severe occurrence under hot and humid weather conditions. The objective of the experiment was to evaluate and select sour passion fruit progenies with resistance to bacterial blight under greenhouse conditions. Thus, it was installed in the experiment Biology Experiment Station owned by the University of Brasilia - UNB. Seeds were sown in polystyrene trays with seventy-two cells $(120 \mathrm{ml} /$ cell), using inert vermiculite (Plantmax $\left.{ }^{\circledR}\right)$ with five seeds per cell. With about forty days after sowing, the seedlings were pricked out and transplanted in plastic trays, one seedling per cell. Then cover with urea fertilization were made. The design used was a randomized block with four replications and six plants per plot and twenty-four progenies in five different experimental trials. The experimental arrangement of split plot was used. The plots were formed by five evaluation times and the subplots for twenty-four progenies. The incidence and severity assessments were conducted at intervals of seven days. We used the scale from 1 to 5, being (1) - plants without symptoms, (2) - sparse lesions on leaves taking up to $10 \%$ of the leaf blade, (3) - coalescing injuries taking 10-33\% of limbo leaf (4) - coalescing lesions taking over $33 \%$ of the leaf blade; and (5) - plant with defoliation. It was observed that the majority of the progenies was highly susceptible (AS) to bacteriosis of which only three progeny whole experiment were classified as susceptible (S). High values of heritability and reason CVg / CVe were observed for AUDPC. These results indicate favorable condition for selection, due to the low environmental effect.
\end{abstract}

Keywords: passiflora edulis sims, breeding, heritability, incidence and severity. 


\section{1 - INTRODUÇÃO}

Dentre as doenças que acometem o maracujazeiro, a bacteriose ou a mancha-oleosa é uma das mais severas, dada a dificuldade de controle, por isso, há necessidade de pesquisas que visem ao melhoramento genético buscando a resistência aos patógenos. A bacteria (Xanthomonas axonopodis pv. Passiflorae) causa inicialmente, nas folhas, lesões pequenas, encharcadas, oleosas, translúcidas, frequentemente localizadas próximas às nervuras, com halos visíveis, as vezes acompanhadas de enegrecimento vascular a partir dos bordos. Em seguida, tornam-se marrons, deprimidas, sobretudo na face dorsal da folha, de formato variado, raramente circulares, com tamanho médio de três a quatro milímetros, podendo coalescer em grandes áreas necrosadas e causando seca total da folha (PIO-RIBEIRO \& MARIANO, 1997). Nessa doença, a partir das lesões foliares, a infecção pode se tornar sistêmica e atingir os ramos, que sofrem uma seca progressiva, apresentando caneluras longitudinais acompanhadas de escurecimento dos feixes vasculares. Cortes transversais de ramos e pecíolos infectados, se comprimidos, apresentam exsudação de massa bacteriana (MALAVOLTA JUNIOR, 1998).

Espécies silvestres do gênero Passiflora ( $P$. laurifolia, $P$. nitida, $P$. tenuifilla, $P$. mucronata, $P$. giberti, P. amethytina, P. quadrangularis, $P$. setacea, $P$. coccinea, $P$. cerulea, entre outras) têm apresentado, com base em estudos preliminares, variabilidade para resistência às principais doenças do maracujazeiro (CUNHA et al., 2002; SANTOS FILHO \& JUNQUEIRA, 2003) e também variabilidade genética (VIEIRA et al., 1997; ANGEL et al., 1998; CASSIANO et al., 1998; CROCHEMORE, 2002; PIO VIANA et al., 2003; FALEIRO et al., 2005). Várias dessas espécies têm sido citadas como potenciais fontes de resistências que podem contribuir para o controle de doenças causadas por fungos (SANTOS FILHO \& SANTOS, 2003), bactérias (SEIXAS, 1989, SANTOS \& SANTOS FILHO, 2003), alguns vírus (REZENDE, 1994) e nematoides (CASTRO, 2008). 
Segundo JUNQUEIRA et al. (2005), entre as várias espécies de passifloras silvestres no Brasil, algumas têm características interessantes que poderiam ser introduzidas no maracujazeiro comercial. Para que toda esta variabilidade genética interessante para resistência às doenças seja aproveitada em programas de melhoramento, torna-se necessária a realização de hibridações intraespecíficas (JUNQUEIRA et al., 2005) ou o uso da biotecnologia moderna na obtenção de híbridos somáticos ou na utilização da tecnologia do DNA recombinante ou da engenharia genética (VIEIRA et al., 2005).

Estudos detalhados de caracterização, seleção e hibridação de genótipos de maracujazeiro são essenciais para subsidiar a utilização do germoplasma de Passiflora em programas de melhoramento genético e na obtenção de materiais produtivos, com boa qualidade de frutos e com resistência ou tolerância aos principais fitopatógenos do maracujazeiro-azedo, como é o caso da bacteriose.

Nesse sentido, esse trabalho teve como objetivo avaliar e selecionar progênies de maracujazeiro-azedo com resistência à bacteriose em condições de casa de vegetação.

\section{2 - MATERIAL E MÉTODOS}

O experimento foi realizado na Estação Experimental de Biologia (EEB) da Universidade de Brasília, no Distrito Federal, em condições de casa de vegetação. A temperatura média na casa de vegetação variou de $26^{\circ} \mathrm{C}$ a $35^{\circ} \mathrm{C}$ e a umidade relativa média do ar próxima de $86 \%$ no período de fevereiro a março de 2012. A altitude do local é de 1.101 metros, latitude Sul de $16^{\circ}$ e longitude oeste de $48^{\circ}$. O clima da região é do tipo $\mathrm{AW}$, caracterizado por chuvas concentradas no verão de outubro a abril e inverno seco, de maio a setembro. A casa de vegetação proporciona ambiente úmido às mudas devido ao sistema de nebulização de dez minutos por hora.

Foram realizados cinco ensaios denominados 01, 02, 03, 04 e 05, e as progênies envolvidas foram: MAR20\#23 Pl.3, 20\#12 Pl.6, 20\#46 Pl.3, $20 \# 19$ Pl.4, $20 \# 44$ Pl.2, 20\#12 P1.2, 29\#24 P1.2, 20\#34 F2, 20\#34 Pl.1, 20\#2005 P1.8, 20\#12 Pl.6, 20\#46 Pl.3, 20\#19 Pl.2, 20\#44 Pl.2, 20\#12 Pl.6, 20\#34 F2, 20\#34 Pl.1, 20\#34 Pl.2, $20 \# 34$ Pl.3, $20 \# 12$ Pl.6, $20 \# 46$ Pl.3, 20\#19 Pl.2, 20\#44 Pl.2, 20\#12 Pl.1, 20\#24 Pl.2, 20\#34 F2, 20\#34 Pl.1, 20\#34 Pl.2, 20\#34 Pl.3, 20\#2005 Pl.8, MAR20\#34 P1.5, 20\#34 Pl.1, 20\#34 Pl.3, $20 \# 34$ F2, 20\#39 Pl.1, 20\#39 Pl.4, 20\#39 Pl.1, 20\#23 Pl.2, 20\#44 F2, 20\#2005 P1.2, 20\#12 Pl.6, $20 \# 19$ Pl.1, $20 \# 19$ Pl.2, 20\#12 Pl.8, 20\#49 Pl.3, 20\#34 Pl.2, 20\#34 F2, $20 \# 34$ Pl.2, $20 \# 34$ Pl.5, 20\#2005 Pl.2, 20\#19 Pl.1, 20\#23 Pl.2, 20\#12 Pl.6, 20\#44 Pl.2, 20\#44 F2, $20 \# 49$ Pl.3, 20\#34 Pl.1, $20 \# 19$ 
P1.2, 20\#34 Pl.3 e Rosa claro, obtidas por seleção massal de plantios comerciais contendo nove materiais superiores, considerando os aspectos de produtividade, qualidade de frutos e resistência aos patógenos, trazidos do município de Araguari, como descritos na Tabela 1.

Tabela 1. Progênies cultivadas em pomares comerciais no município de Araguari/MG utilizadas na seleção massal.

\begin{tabular}{|c|l|}
\hline ITEM & \multicolumn{1}{|c|}{ PROGÊEIES } \\
\hline 1 & Maguary “Mesa 1" \\
\hline 2 & Maguary "Mesa 2" \\
\hline 3 & Havaiano \\
\hline 4 & Marília Seleção Cerrado (MSC) \\
\hline 5 & Seleção DF \\
\hline 6 & EC-2-O \\
\hline 7 & $\mathrm{~F}_{1}$ (Marília x Roxo Australiano) \\
\hline 8 & $\mathrm{~F}_{1}[$ Roxo Fiji (introdução das ilhas Fiji) x Marília] \\
\hline 9 & $\begin{array}{l}\text { RC }{ }_{1}\left[\mathrm{~F}_{1}(\text { Marília (seleção da Cooperativa Sul Brasil de Marília }-\mathrm{SP} \text { ) x Roxo }\right. \\
\text { Australiano) x Marília (pai recorrente)]. }\end{array}$ \\
\hline
\end{tabular}

Os materiais do ensaio 01 denominados, RC3 Pl.1, RC3 P1.2, RC3 Pl.3, AR1 Pl.3, AR1 Pl.4, Rosa intenso, Rosa Claro, Rubi Gig. Pl.1, PA 01; MSCA P1.3, FB 200 Pl.1; Gig Am Pl.4; AP1 Pl.1 e ECL 7 Pl.3 foram obtidos conforme descrito na Tabela 2.

Tabela 2. Procedência de 11 progênies de maracujazeiro-azedo avaliados no Distrito Federal, fazenda Água Limpa (FAL) - UnB, 2012 e 2013.

\begin{tabular}{|c|l|}
\hline PROGÊNIES & \multicolumn{1}{|c|}{ ORIGEM } \\
\hline RC3 & Híbrido de seleção recorrente (P. edulis f. flavicarpa x P. setacea) \\
\hline AR1 & $\begin{array}{l}\text { Híbrido (RC1) de polinização controlada entre as cultivares Marília x Roxo } \\
\text { Australiano retrocruzado para Marília, ou seja, F1 x Marília }\end{array}$ \\
\hline Rosa Intenso & $\begin{array}{l}\text { Seleção recorrente baseada em família de 1/2 irmãos entre diversos } \\
\text { genótipos de Passiflora edulis }\end{array}$ \\
\hline PA 01 & $\begin{array}{l}\text { Seleção recorrente baseada em família de 1/2 irmãos entre diversos } \\
\text { genótipos de Passiflora edulis }\end{array}$ \\
\hline Rosa Claro & EC-2-O \\
\hline Rubi Gig.Pl.1 & $\begin{array}{l}\text { Seleção recorrente baseada em família de 1/2 irmãos entre diversos } \\
\text { genótipos de Passiflora edulis }\end{array}$ \\
\hline MSCA & Marília seleção cerrado \\
\hline FB 200 & Cultivar comercial \\
\hline Gig Am P1.4 & F1 (Redondão X MSC) \\
\hline AP1 Pl.1 & $\begin{array}{l}\text { Seleção recorrente baseada em família de 1/2 irmãos entre diversos } \\
\text { genótipos de Passiflora edulis }\end{array}$ \\
\hline ECL 7 P1.3 & $\begin{array}{l}\text { Seleção recorrente baseada em família de 1/2 irmãos entre diversos } \\
\text { genótipos de Passiflora edulis }\end{array}$ \\
\hline
\end{tabular}


Os materiais do ensaio 02 denominados RC3 Pl.2, RC3 Pl.3, AR1 Pl.4, Rosa intenso, Rosa claro, Rubi Gig. Pl.1; PA 01, MSCA Pl.3, AP1 Pl.1; ECL 7 Pl.3; Desconhecido 1, Desconhecido 2; Palata N1. EC3 - 0 Pl.2, EC3 - 0 Pl.4 foram obtidos conforme descrito na Tabela 3.

Tabela 3. Procedência de catorze progênies de maracujazeiro-azedo avaliadas no Distrito Federal, Fazenda Água Limpa - UnB, 2012 e 2013.

\begin{tabular}{|c|c|}
\hline \multicolumn{2}{|r|}{ Ensaio 02} \\
\hline PROGÊNIES & ORIGEM \\
\hline MAR 20\#01 & $\begin{array}{l}\text { Seleção recorrente baseada em família de } 1 / 2 \text { irmãos entre diversos } \\
\text { genótipos de Passiflora edulis }\end{array}$ \\
\hline AR1 & $\begin{array}{l}\text { Híbrido (RC1) de polinização controlada entre as cultivares Marília x Roxo } \\
\text { Australiano retrocruzado para Marília, ou seja, F1 x Marília }\end{array}$ \\
\hline MSCA & Marília seleção cerrado \\
\hline Rosa Intenso & Seleção recorrente baseada em família de $1 / 2$ irmãos \\
\hline $\mathrm{EC} 3-0$ & $\begin{array}{l}\text { Híbrido (RC1) de polinização controlada entre as cultivares Marília x Roxo } \\
\text { Australiano retrocruzado para Marília, ou seja, F1 x Marília }\end{array}$ \\
\hline AP1 & $\begin{array}{l}\text { Cultivar obtida do cruzamento entre tipos de maracujazeiro-azedo de alta } \\
\text { produtividade, selecionados em pomar comercial }\end{array}$ \\
\hline RC3 & Híbrido de seleção recorrente (P. edulis $f$. flavicarpa $\times$ P. setacea $)$ \\
\hline Rosa Claro & $\begin{array}{l}\text { Seleção recorrente baseada em família de } 1 / 2 \text { irmãos entre diversos } \\
\text { genótipos de Passiflora edulis }\end{array}$ \\
\hline MAR 20\#02 & $\begin{array}{l}\text { Seleção recorrente baseada em família de } 1 / 2 \text { irmãos entre diversos } \\
\text { genótipos de Passiflora edulis }\end{array}$ \\
\hline ECL7 & Derivado da cultivar Marília \\
\hline PA 01 & Seleção recorrente baseada em família de $1 / 2$ irmãos \\
\hline Planta N1 & $\begin{array}{l}\text { Cultivar oriunda de } 1 / 2 \text { irmãos obtidos de uma planta selecionada numa } \\
\text { população de indivíduos de } P \text {. edulis amarelo e de híbridos interespecíficos }\end{array}$ \\
\hline $\begin{array}{l}\text { Rubi Gigante } \\
\text { Pl.1 }\end{array}$ & $\begin{array}{l}\text { Seleção recorrente baseada em família de } 1 / 2 \text { irmãos entre diversos } \\
\text { genótipos de Passiflora edulis }\end{array}$ \\
\hline
\end{tabular}

Para os materiais do ensaio 03 denominados, RC3 P1.2, AR1 Pl.3, AR1 Pl.4, Rubi Gig; MSCA Pl.3; FB 200 Pl.1; FB 200 Pl.3, AP1 Pl.1, EC3 - 0 Pl.4, EC3 - 0 Pl.2, Desconhecido 1 e Desconhecido 2 foram obtidos conforme descrito na Tabela 4. 
Tabela 4. Procedência de onze progênies de maracujazeiro-azedo avaliados no Distrito Federal, fazenda Água Limpa - UnB, 2012 e 2013.

\section{Ensaio 03}

\begin{tabular}{|c|l|}
\hline PROGÊNIES & \multicolumn{1}{|c|}{ ORIGEM } \\
\hline Rubi Gigante & (Roxo australiano x Marília) \\
\hline FB200 P1.1 & Cultivar comercial \\
\hline MSCA & Seleção recorrente baseada em família de 1/2 irmãos \\
\hline FB200 P1.1 & Cultivar comercial \\
\hline EC3 - 0 & $\begin{array}{l}\text { Híbrido (RC1) de polinização controlada entre as cultivares Marília x Roxo } \\
\text { Australiano retrocruzado para Marília, ou seja, F1 x Marília }\end{array}$ \\
\hline AP1 & $\begin{array}{l}\text { Cultivar obtida do cruzamento entre tipos de maracujazeiro-azedo de alta } \\
\text { produtividade, selecionados em pomar comercial. }\end{array}$ \\
\hline AR1 & $\begin{array}{l}\text { Híbrido (RC1) de polinização controlada entre as cultivares Marília x Roxo } \\
\text { Australiano retrocruzado para Marília, ou seja, F1 x Marília }\end{array}$ \\
\hline MAR 20\#01 & $\begin{array}{l}\text { Seleção recorrente baseada em família de 1/2 irmãos entre diversos } \\
\text { genótipos de Passiflora edulis }\end{array}$ \\
\hline MAR 20\#02 & $\begin{array}{l}\text { Seleção recorrente baseada em família de 1/2 irmãos entre diversos } \\
\text { genótipos de Passiflora edulis }\end{array}$ \\
\hline RC3 PL.2 & Híbrido de seleção recorrente (P. edulis f. flavicarpa $x$ P. setacea) \\
\hline FB200 P1.3 & Cultivar comercial \\
\hline
\end{tabular}

Para os materiais do ensaio 04 denominados FB200 P1.1, RC03 P1.2, RC03 PL.3, EC3-0 Pl.4, ECL7 P1.3, ECL7 Pl.4, Desconhecido 1 e Desconhecido 2 foram obtidos conforme descrito na Tabela 5 .

Tabela 5. Procedência de sete progênies de maracujazeiro-azedo avaliados no Distrito Federal, fazenda Água Limpa - UnB, 2012 e 2013.

\section{Ensaio 04}

\begin{tabular}{|c|l|}
\hline PROGÊNIES & \multicolumn{1}{c|}{ ORIGEM } \\
\hline MAR 20\#02 & $\begin{array}{l}\text { Seleção recorrente baseada em família de 1/2 irmãos entre diversos } \\
\text { genótipos de Passiflora edulis }\end{array}$ \\
\hline FB200 & Cultivar comercial \\
\hline RC03 PL.3 & Híbrido de seleção recorrente (P. edulis f. flavicarpa x P. setacea) \\
\hline EC3 - 0 & $\begin{array}{l}\text { Híbrido (RC1) de polinização controlada entre as cultivares Marília x Roxo } \\
\text { Australiano retrocruzado para Marília, ou seja, F1 x Marília }\end{array}$ \\
\hline ECL7 & Derivado da cultivar Marília \\
\hline MAR 20\#01 & $\begin{array}{l}\text { Seleção recorrente baseada em família de 1/2 irmãos entre diversos } \\
\text { genótipos de Passiflora edulis }\end{array}$ \\
\hline RC03 & Híbrido de seleção recorrente $(P$. edulis f. flavicarpa x P. setacea) \\
\hline
\end{tabular}

Para os materiais do ensaio 05 denominados, RC3 P1.2, RC3 P1.3, PA01, Rosa Claro, Rosa Intenso, ECL P1.4, ECL7 P1.3, EC3-0 P1.4, AP1 Pl.1, FB200 Pl.1 e Desconhecido 2, foram obtidos conforme descrito na Tabela 6. 
Tabela 6. Procedência de nove progênies de maracujazeiro-azedo avaliados no Distrito Federal, fazenda Água Limpa - UnB, 2012 e 2013.

\section{Ensaio 05}

\begin{tabular}{|c|l|}
\hline PROGÊNIES & \multicolumn{1}{c|}{ ORIGEM } \\
\hline PA01 & Seleção recorrente baseada em família de 1/2 irmãos \\
\hline Rosa Claro & Seleção recorrente baseada em família de 1/2 irmãos \\
\hline Rosa Intenso & Seleção recorrente baseada em família de 1/2 irmãos \\
\hline RC3 & Híbrido de seleção recorrente $(P$. edulis Sims. $x$ P. setacea $)$ \\
\hline MAR 20\#02 & $\begin{array}{l}\text { Seleção recorrente baseada em família de 1/2 irmãos entre diversos } \\
\text { genótipos de Passiflora edulis }\end{array}$ \\
\hline FB200 & Cultivar comercial \\
\hline AP1 & $\begin{array}{l}\text { Cultivar obtida do cruzamento entre tipos de maracujazeiro-azedo de alta } \\
\text { produtividade, selecionados em pomar comercial. }\end{array}$ \\
\hline EC3 -0 & $\begin{array}{l}\text { Híbrido (RC1) de polinização controlada entre as cultivares Marília x Roxo } \\
\text { Australiano retrocruzado para Marília, ou seja, F1 x Marília }\end{array}$ \\
\hline ECL7 & Derivado da cultivar Marília \\
\hline
\end{tabular}

As semeaduras foram feitas em bandejas de polietileno expandidos de cento vinte e oito células (40 ml/célula), com substrato vermiculita (Plantmax $\left.{ }^{\circledR}\right)$. Foram colocadas cinco sementes por célula. Com aproximadamente quarenta dias da semeadura, as mudas foram transplantadas para bandejas de polietileno, uma muda por célula. Após o transplante das mudas, foram feitas adubações de cobertura com nitrogênio amídico (Ureia) na dose aproximada de $6 \mathrm{~g}$ por bandeja na concentração de $10 \mathrm{~g} / \mathrm{l}$ semanalmente.

O isolado de Xanthomonas axonopodis pv. passiflorae utilizado foi da coleção de bactérias fitopatogênicas do Laboratório de Fitopatologia da Universidade de Brasília, preservada sob o número UnB-767, em uma concentração estimada de $10^{6} \mathrm{UFC} / \mathrm{ml}$ (unidade formadoras de colônia).

A inoculação foi realizada após oitenta dias de transplantio, quando estas plantas apresentavam de cinco a seis folhas. As perfurações foram feitas em duas folhas, em seu terço médio, com o auxílio de escova de cerdas de aço fino e, logo em seguida, o patógeno foi inoculado. A inoculação foi realizada ao final da tarde, através da aspersão da suspensão do isolado, tanto na face abaxial quanto na face adaxial da folha. Segundo MALNATI et al. (1993), o método de pulverização é o mais indicado, pois além de gastar menos tempo para a inoculação, resulta em lesões melhor distribuídas nas folhas. Após a inoculação, as plantas foram colocadas em baixo das bancadas e cobertas com plástico durante setenta e duas horas, a fim de simular uma estufa fechada. As plantas foram mantidas em casa de vegetação, que manteve o aspecto de uma grande câmara úmida, onde permaneceram até o término do experimento. 
Foram realizadas cinco avaliações de severidade medida através da escala de notas, levando-se em consideração a porcentagem de área foliar lesionada e de incidência (porcentagem de plantas com sintomas) da doença. A primeira avaliação foi feita 16 dias após a inoculação. As avaliações seguintes foram feitas após intervalos de tempo de aproximadamente sete dias a partir da data da inoculação.

As avaliações de severidade da doença foram realizadas utilizando a escala de notas abaixo (DIAS, 1990, com modificações), considerando o sintoma mais severo presente nas folhas das plantas.

\section{Escala de Notas (Figura 8):}

$\checkmark 0=$ planta sem sintomas;

$\checkmark 1=$ até $25 \%$ da área da folha apresentando manchas;

$\checkmark 2=25-50 \%$ da área da folha com manchas;

$\checkmark 3=$ mais de $50 \%$ da área da folha com manchas;

$\checkmark 4$ = planta apresentando desfolha e seca.

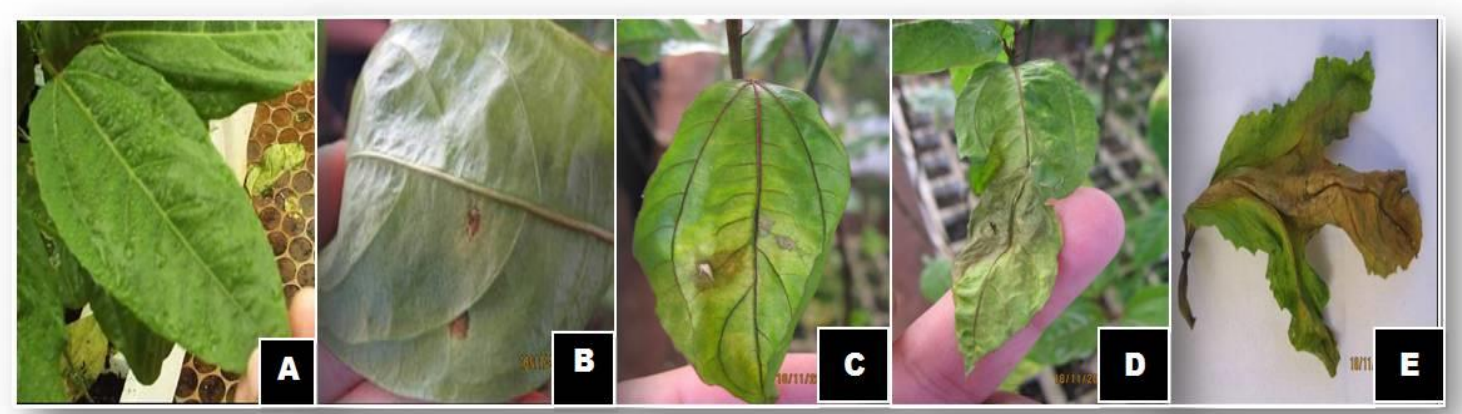

Figura 8 - Escala de notas empregadas na avaliação da severidade da doença em plantas de maracujá-azedo inoculadas com $X$. axonopodis pv. Passiflorae. (A - nota $0 ; \mathbf{B}$ - nota 1; $\mathbf{C}$ $-\operatorname{nota} 2 ; \mathbf{D}-\operatorname{nota} 3 ; \mathbf{E}-\operatorname{nota} 4)$.

O critério para classificação das plantas e progênies como resistentes $(\mathrm{R})$, medianamente resistentes (MR), medianamente suscetíveis (MS), suscetíveis (S) e altamente suscetíveis (AS) foi baseado na nota média, de acordo com a Tabela 7. 
Tabela 7. Classificação das plantas inoculadas com Xanthomonas axonopodis pv. passiflorae, em função da escala de notas médias.

\begin{tabular}{|c|c|}
\hline NOTAS & CLASSIFICAÇÃO \\
\hline$=0 \mathrm{e}<1$ & Resistentes (R) \\
\hline$\geq 1 \mathrm{e}<2$ & Medianamente resistentes (MR) \\
\hline$\geq 2 \mathrm{e}<3$ & Medianamente suscetíveis (MS) \\
\hline$\geq 3 \mathrm{e}<4$ & Suscetíveis (S) \\
\hline$\geq 4$ & Altamente suscetíveis (AS) \\
\hline
\end{tabular}

Foram atribuídas notas de 0 a 5 com base em valores de severidade a partir da escala de notas proposta por (DIAS, 1990), a qual foi adaptada por (BOUZA, 2009). Entre as folhas previamente feridas, foram escolhidas duas folhas localizadas na região central da planta para avaliação.

Os dados obtidos foram submetidos à análise de variância e as médias agrupadas, entre si, pelo teste de Scott-Knott a 5\% de significância (SCOTT \& KNOTT, 1974). Foram também estimados os coeficientes de variação experimental (CVe), genético (CVg) e herdabilidade no sentido amplo $\left(\mathrm{h}^{2}\right)$, para cada uma das características, com auxílio do programa Genes (CRUZ, 2007).

A partir dos dados coletados nas cinco avaliações foi obtida a curva de progresso da doença, calculando-se a área abaixo da curva, a fim de avaliar a possibilidade de a patologia ser empregada como parâmetro de diferenciação de genótipos quanto à resistência à bacteriose.

Com os dados de incidência e severidade das diferentes avaliações, calculou-se a área abaixo da curva de progresso da doença (AACPD) pelo método da integralização trapezoidal (BERGER, 1988).

Para o cálculo da AACPD, utilizou-se a seguinte fórmula em que:

$$
\sum_{1}^{n-1}\left(\frac{y 1+y 1+1}{2}\right)(t 1+1-t 1)
$$

$\mathrm{n}=$ número de avaliações, $\mathrm{y}=$ intensidade da doença, $\mathrm{t}=$ tempo durante a avaliação da intensidade da doença, $(y i+y i+1)=$ altura média do retângulo entre os pontos yi e yi +1 , ti $+1=$ diferença da base do retângulo entre os pontos ti +1 e ti. A curva de progresso da doença pode ser expressa pela proporção de doença x tempo.

Para o cálculo da área abaixo da curva de progresso da doença, foi utilizado o programa de computador EXCEL proposta por (SHANER \& FINNEY, 1997) apud (MARTINS, 2005), utilizando-se o programa SISVAR (FERREIRA, 2000). 
Os dados obtidos foram submetidos à análise de variância e as médias agrupadas, entre si, pelo teste de Scott-Knott a 5\% de significância (SCOTT \& KNOTT, 1974). Foram também estimados os coeficientes de variação experimental (CVe), genético (CVg) e herdabilidade no sentido amplo $\left(\mathrm{h}^{2}\right)$, para cada uma das características, com auxílio do programa Genes (CRUZ, 2007).

\section{3 - RESULTADOS E DISCUSSÃO}

Não houve diferenças estatísticas para severidade (percentual da superfície da folha coberta com lesões) à bacteriose nas cinco épocas de avaliação. A maioria das progênies foi altamente suscetível (AS) à bacteriose em casa de vegetação Tabelas (8, 9, 10, 11 e 12), conforme escala diagramática sugerida por JUNQUEIRA et al. (2003). Somente uma progênie do ensaio 02 (RC3 Pl.3) e duas do ensaio 05 (ECL Pl.4 e MAR20\#23 Pl.2) foram classificadas como suscetíveis (S). Com isso, verificou-se que do total de 120 progênies apenas três foram classificadas como suscetíveis (S) e todas as outras foram classificadas como altamente suscetíveis (AS) à bacteriose. Além da suscetibilidade das progênies, esses resultados demonstram pouca variabilidade genética para resistência à bacteriose e que houve alta pressão de inóculo, nesse trabalho de 'screening'.

Tabela 8. Ensaio 01- Média de Severidade e grau de resistência à bacteriose causada por Xanthomonas axonopodis pv. passiflorae em vinte e quatro progênies de maracujazeiroazedo, sob condições de casa de vegetação. Estação Biológica - UnB 2012.

\section{Ensaio 01}

\begin{tabular}{|c|c|c|}
\hline PROGÊNIES & MÉDIA DE SEVERIDADE & GRAU DE RESISTENCIA \\
\hline RC3 Pl.3 & $4,3 \mathrm{a}$ & AS \\
\hline MAR20\#23 Pl.3 & $5,9 \mathrm{a}$ & AS \\
\hline MAR20\#12 Pl.6 & $5,2 \mathrm{a}$ & AS \\
\hline MAR20\#46 Pl.3 & $5,3 \mathrm{a}$ & AS \\
\hline MAR20\#19 Pl.4 & $5,0 \mathrm{a}$ & AS \\
\hline AR1 P1.3 & $5,7 \mathrm{a}$ & AS \\
\hline Rosa intenso & $4,8 \mathrm{a}$ & AS \\
\hline MAR20\#44 Pl.2 & $5,3 \mathrm{a}$ & AS \\
\hline MAR20\#12 Pl.2 & $5,8 \mathrm{a}$ & AS \\
\hline RC3 Pl.2 & $5,2 \mathrm{a}$ & AS \\
\hline PA 01 & $5,0 \mathrm{a}$ & AS \\
\hline MAR20\#24 Pl.2 & $5,6 \mathrm{a}$ & AS \\
\hline RC3 Pl.1 & $6,5 \mathrm{a}$ & AS \\
\hline Rosa Claro & $6,3 \mathrm{a}$ & AS \\
\hline Rubi Gig.Pl.1 & $6,3 \mathrm{a}$ & \\
\hline
\end{tabular}




\begin{tabular}{|c|c|c|}
\hline MSCA P1.3 & $5,6 \mathrm{a}$ & AS \\
\hline AR1 P1.4 & $6,0 \mathrm{a}$ & AS \\
\hline MAR20\#34 F2 & $5,5 \mathrm{a}$ & AS \\
\hline FB 200 Pl.1 & $5,0 \mathrm{a}$ & AS \\
\hline Gig Am Pl.4 & $5,0 \mathrm{a}$ & AS \\
\hline AP1 Pl.1 & $5,1 \mathrm{a}$ & AS \\
\hline MAR20\#34 Pl.1 & $6,3 \mathrm{a}$ & AS \\
\hline MAR20\#2005 Pl.8 & $5,6 \mathrm{a}$ & AS \\
\hline ECL 7 Pl.3 & $5,7 \mathrm{a}$ & AS \\
\hline
\end{tabular}

* Médias na coluna seguidas pelas mesmas letras não diferem estatisticamente entre si pelo teste de Scott Knott ao nível de 5\%

Tabela 9. Ensaio 02 - Média de Severidade e grau de resistência à bacteriose causada por Xanthomonas axonopodis pv. passiflorae em vinte e quatro progênies de maracujazeiroazedo, sob condições de casa de vegetação. Estação Biológica - UnB 2012.

\section{Ensaio 02}

\begin{tabular}{|c|c|c|}
\hline PROGÊNIES & $\begin{array}{c}\text { MÉDIA DE } \\
\text { SEVERIDADE }\end{array}$ & GRAU DE RESISTÊNCIA \\
\hline MAR20\#34 Pl.3 & $5,2 \mathrm{a}$ & AS \\
\hline MAR20\#34 Pl.3 & $5,8 \mathrm{a}$ & AS \\
\hline MAR 20\#01 & $4,6 \mathrm{a}$ & AS \\
\hline AR 1 Pl.4 & $5,3 \mathrm{a}$ & AS \\
\hline MAR20\#19 Pl.2 & $4,8 \mathrm{a}$ & AS \\
\hline MAR20\#34 Pl.1 & $5,7 \mathrm{a}$ & AS \\
\hline MAR20\#44 Pl.2 & $4,8 \mathrm{a}$ & AS \\
\hline MAR20\#34 Pl.2 & $5,5 \mathrm{a}$ & AS \\
\hline MSCA Pl.3 & $4,9 \mathrm{a}$ & AS \\
\hline Rosa Intenso & $5,5 \mathrm{a}$ & AS \\
\hline EC3-0 P1.2 & $4,4 \mathrm{a}$ & AS \\
\hline MAR 20\#46 Pl.3 & $5,1 \mathrm{a}$ & AS \\
\hline AP1 Pl.1 & $5,5 \mathrm{a}$ & AS \\
\hline RC3 Pl.2 & $6,4 \mathrm{a}$ & AS \\
\hline Rosa Claro & $5,3 \mathrm{a}$ & AS \\
\hline MAR 20\#02 & $5,2 \mathrm{a}$ & AS \\
\hline ECL7 Pl.3 & $5,8 \mathrm{a}$ & AS \\
\hline PA 01 & $4,9 \mathrm{a}$ & AS \\
\hline MAR20\#12 Pl.6 & $6,0 \mathrm{a}$ & AS \\
\hline MAR20\#34 F2 & $5,3 \mathrm{a}$ & AS \\
\hline Palata N1 & $5,6 \mathrm{a}$ & AS \\
\hline Rubi Gigante Pl.1 & $5,7 \mathrm{a}$ & S \\
\hline RC3 Pl.3 & $\mathbf{3 , 5 a}$ & AS \\
\hline EC3 - 0 Pl.4 & $4,3 \mathrm{a}$ & \\
\hline
\end{tabular}


* Médias na coluna seguidas pelas mesmas letras não diferem estatisticamente entre si pelo teste de Scott Knott ao nível de 5\%.

Tabela 10. Ensaio 03 - Média de Severidade e grau de resistência à bacteriose causada por Xanthomonas axonopodis pv. passiflorae em vinte e quatro progênies de maracujazeiroazedo, sob condições de casa de vegetação. Estação Biológica - UnB 2012.

\begin{tabular}{|c|c|c|}
\multicolumn{4}{c}{ Ensaio 03 } \\
\hline PROGÊNIES & MÉDIA DE SEVERIDADE & GRAU DE RESISTÊNCIA \\
\hline MAR20\#12 Pl.6 & $5,5 \mathrm{a}$ & AS \\
\hline MAR20\#34 Pl.2 & $4,8 \mathrm{a}$ & AS \\
\hline Rubi Gigante & $4,0 \mathrm{a}$ & AS \\
\hline MAR20\#44 Pl.2 & $4,0 \mathrm{a}$ & AS \\
\hline FB200 Pl.1 & $5,0 \mathrm{a}$ & AS \\
\hline MAR20\#46 Pl.3 & $4,6 \mathrm{a}$ & AS \\
\hline MAR20\#24 Pl.2 & $4,6 \mathrm{a}$ & AS \\
\hline MSCA Pl.3 & $5,3 \mathrm{a}$ & AS \\
\hline FB200 Pl.1 & $5,0 \mathrm{a}$ & AS \\
\hline EC3-0 Pl.2 & $4,4 \mathrm{a}$ & AS \\
\hline AP1 Pl.1 & $5,0 \mathrm{a}$ & AS \\
\hline AR1 P1.4 & $4,7 \mathrm{a}$ & AS \\
\hline AR1 Pl.3 & $5,3 \mathrm{a}$ & AS \\
\hline MAR 20\#01 & $4,6 \mathrm{a}$ & AS \\
\hline MAR 20\#02 & $5,6 \mathrm{a}$ & AS \\
\hline MAR20\#2005 Pl.8 & $5,5 \mathrm{a}$ & AS \\
\hline MAR20\#12 Pl.1 & $4,6 \mathrm{a}$ & AS \\
\hline MAR20\#34 F2 & $5,6 \mathrm{a}$ & AS \\
\hline MAR20\#34 Pl.1 & $5,2 \mathrm{a}$ & AS \\
\hline EC3-0 Pl.4 & $5,3 \mathrm{a}$ & AS \\
\hline MAR20\#19 Pl.2 & $5,9 \mathrm{a}$ & AS \\
\hline RC3 PL.2 & $5,8 \mathrm{a}$ & AS \\
\hline MAR20\#34 Pl.3 & $6,5 \mathrm{a}$ & AS \\
\hline FB200 Pl.3 & $4,8 \mathrm{a}$ & AS \\
\hline
\end{tabular}

* Médias na coluna seguidas pelas mesmas letras não diferem estatisticamente entre si pelo teste de Scott Knott ao nível de 5\%. 
Tabela 11. Ensaio 04 - Média de Severidade e grau de resistência à bacteriose causada por Xanthomonas axonopodis pv. passiflorae em vinte e quatro progênies de maracujazeiroazedo, sob condições de casa de vegetação. Estação Biológica - UnB 2012.

\section{Ensaio 04}

\begin{tabular}{|c|c|c|}
\hline PROGÊNIES & MÉDIA DE SEVERIDADE & GRAU DE RESISTENCIA \\
\hline MAR 20\#02 & $6,1 \mathrm{a}$ & AS \\
\hline MAR20\#34 Pl.5 & $5,8 \mathrm{a}$ & AS \\
\hline FB200 Pl.1 & $4,7 \mathrm{a}$ & AS \\
\hline MAR20\#34 F2 & $6,3 \mathrm{a}$ & AS \\
\hline MAR20\#39 Pl.4 & $5,7 \mathrm{a}$ & AS \\
\hline RC03 P1.3 & $5,0 \mathrm{a}$ & AS \\
\hline MAR20\#2005 Pl.6 & $5,7 \mathrm{a}$ & AS \\
\hline MAR20\#2005 Pl.2 & $5,0 \mathrm{a}$ & AS \\
\hline MAR20\#34 Pl.3 & $6,1 \mathrm{a}$ & AS \\
\hline MAR20\#23 Pl.2 & $4,5 \mathrm{a}$ & AS \\
\hline MAR20\#34 Pl.1 & $5,2 \mathrm{a}$ & AS \\
\hline MAR20\#44 F2 & $6,0 \mathrm{a}$ & AS \\
\hline MAR20\#39 Pl.1 & $5,1 \mathrm{a}$ & AS \\
\hline MAR20\#12 Pl.6 & $5,2 \mathrm{a}$ & AS \\
\hline EC7 P1.4 & $5,4 \mathrm{a}$ & AS \\
\hline EC3-0 P1.4 & $5,3 \mathrm{a}$ & AS \\
\hline MAR20\#19 Pl.1 & $5,7 \mathrm{a}$ & AS \\
\hline EC7 Pl.3 & $4,6 \mathrm{a}$ & AS \\
\hline MAR 20\#01 & $5,9 \mathrm{a}$ & AS \\
\hline MAR20\#19 Pl.2 & $4,2 \mathrm{a}$ & AS \\
\hline MAR20\#12 Pl.8 & $5,3 \mathrm{a}$ & AS \\
\hline MAR20\#49 Pl.3 & $6,1 \mathrm{a}$ & AS \\
\hline MAR20\#34 Pl.2 & $5,4 \mathrm{a}$ & AS \\
\hline RC03 P1.2 & $5,4 \mathrm{a}$ & \\
\hline
\end{tabular}

* Médias na coluna seguidas pelas mesmas letras não diferem estatisticamente entre si pelo teste de Scott Knott ao nível de 5\%.

Tabela 12. Ensaio 05 - Média de Severidade e grau de resistência à bacteriose causada por Xanthomonas axonopodis pv. passiflorae em vinte e quatro progênies de maracujazeiroazedo, sob condições de casa de vegetação. Estação Biológica - UnB 2012.

\section{Ensaio 05}

\begin{tabular}{|c|c|c|}
\hline \multirow{2}{*}{ PROGÊNIES } & $\begin{array}{c}\text { MÉDIA DE } \\
\text { SEVERIDADE }\end{array}$ & GRAU DE RESISTÊNCIA \\
\hline MAR20\#34 F2 & $4,6 \mathrm{a}$ & AS \\
\hline PA01 & $5,6 \mathrm{a}$ & AS \\
\hline MAR20\#34 P1.2 & $5,4 \mathrm{a}$ & AS \\
\hline Rosa Claro & $5,6 \mathrm{a}$ & AS \\
\hline Rosa Intenso & $5,4 \mathrm{a}$ & AS \\
\hline RC3P1.3 & $5,3 \mathrm{a}$ & AS \\
\hline
\end{tabular}




\begin{tabular}{|c|c|c|}
\hline MAR20\#34 P1.5 & $5,4 \mathrm{a}$ & AS \\
\hline MAR20\#2005 Pl.2 & $5,2 \mathrm{a}$ & AS \\
\hline ECL P1.4 & $3,7 \mathrm{a}$ & S \\
\hline MAR20\#19 Pl.1 & $5,4 \mathrm{a}$ & AS \\
\hline MAR20\#23 Pl.2 & $3,9 \mathrm{a}$ & AS \\
\hline Desconhecido 2 & $5,2 \mathrm{a}$ & AS \\
\hline FB200 Pl.1 & $4,9 \mathrm{a}$ & AS \\
\hline RC3 Pl.2 & $5,7 \mathrm{a}$ & AS \\
\hline AP1 Pl.1 & $6,0 \mathrm{a}$ & AS \\
\hline MAR20\#12 Pl.6 & $6,4 \mathrm{a}$ & AS \\
\hline MAR20\#44 Pl.2 & $5,6 \mathrm{a}$ & AS \\
\hline MAR20\#44 F2 & $5,7 \mathrm{a}$ & AS \\
\hline MAR20\#49 Pl.3 & $6,3 \mathrm{a}$ & AS \\
\hline EC3-0 Pl.4 & $4,8 \mathrm{a}$ & AS \\
\hline MAR20\#34 Pl.1 & $4,7 \mathrm{a}$ & AS \\
\hline ECL7 Pl.3 & $5,3 \mathrm{a}$ & AS \\
\hline MAR20\#19 Pl.2 & $5,5 \mathrm{a}$ & AS \\
\hline MAR20\#34 Pl.3 & $4,5 \mathrm{a}$ & \\
\hline
\end{tabular}

* Médias na coluna seguidas pelas mesmas letras não diferem estatisticamente entre si pelo teste de Scott Knott ao nível de 5\%.

COLATTO, (2010) em experimento conduzido em casa de vegetação com vinte e quatro progênies classificou uma progênie como moderadamente suscetível (MS), cinco progênies como suscetíveis (S) à bacteriose e todas as demais progênies (um total de dezoito) foram classificadas como altamente suscetíveis (AS) à Xanthomonas axonopodis pv. passiflorae.

SOUZA, (2009) trabalhando com vinte e quatro progênies de maracujazeiro-azedo, classificou uma progênie como moderadamente resistente (BRS Gigante Amarelo) e as demais como altamente suscetíveis à doença.

SOUZA, (2009) trabalhando com vinte e quatro progênies de maracujazeiro-azedo, de propagação por sementes sob condições de casa de vegetação e com inóculo artificial de Xanthomonas axonopodis pv. passiflorae observou que apenas as progênies PL5, MAR 20\#39 e GA2, comportaram-se como suscetíveis (S) e que todas as outras progênies foram classificadas como moderadamente suscetíveis (MS) à doença. No presente trabalho, as progênies MAR 20\#39 e GA2 foram classificadas como altamente suscetíveis (AS) à doença estudada, diferindo dos resultados apresentados por (SOUSA, 2009). Já as progênies ECL7, MAR20\#34, MAR20\#46, EC3-0, Rubi Gigante, MAR 20\#12, MAR20\#2005, MAR20\#24, MAR20\#23 apresentaram comportamento moderadamente suscetível (MS) diferindo do 
presente trabalho, pois no mesmo trabalho essas progênies apresentaram comportamento altamente suscetível (AS).

VIANA, (2007) avaliando a resistência de várias progênies à bacteriose em casa de vegetação com diferentes métodos de inoculação, mostrou que o material MSCA comportouse como resistente à doença. Tal resultado difere do presente trabalho que a mesma progênie comportou-se como altamente suscetível (AS). Outras diferenças foram observadas FB 100, Rubi Gigante, MAR 20\#24, MAR 20\#41 e MAR 20\#19 e consideradas medianamente suscetíveis (MS) nos resultados de (VIANA, 2007) diferindo dos resultados observados no presente trabalho em que todas as progênies foram classificadas como altamente suscetíveis (AS).

Os diferentes resultados mencionados podem ser explicados possivelmente pelas: 1 diferenças existentes entre e dentro das progênies; 2 - por se tratar de progênies oriundas de alguns ciclos de seleção recorrente baseada em família de 1/2 irmãos; 3 - variabilidade do patógeno, entre outras variações, tais como: diferentes isolados de bactéria, que podem ter divergências quanto ao grau de agressividade, ao emprego de diferentes concentrações de inóculo e ao método de inoculação; 4 - condições climáticas como temperatura e umidade relativa do ar que podem influenciar no ritmo de crescimento do patógeno; e 5 - fatores nutricionais das mudas e idades das plantas inoculadas podem provocar divergências.

Os parâmetros genéticos são utilizados para caracterizar uma população e são importantes para definir as melhores estratégias de seleção visando ao maior ganho genético. No presente trabalho, as estimativas de parâmetros genéticos para as variáveis respostas incidência, severidade e AACPD estão apresentadas na Tabela 13.

A herdabilidade observada para incidência nos ensaios 01, 02, 03, 04 e 05 foi respectivamente de $19,54 \%, 16,86 \%, 0,00 \%, 17,31 \%$ e $0,00 \%$. A razão $\mathrm{CVg} / \mathrm{CVe}$ foi de 0,24 , $0,22,0,00,0,22$ e 0,00, respectivamente, e todos os valores abaixo de 1 , o que reflete uma condição desfavorável à seleção, uma vez que a variância genética foi menor que a variância ambiental. Já a herdabilidade observada para severidade nos ensaios 01, 02, 03, 04 e 05 foi respectivamente de $0,00 \%, 32,79 \%, 8,6 \%, 31,86 \%$ e $51 \%$. A razão $\mathrm{CVg} / \mathrm{CVe}$ foi de, respectivamente, $0,00,0,34,0,15,0,34$ e 0,51 , sendo todos os valores abaixo de 1 , o que reflete uma condição desfavorável à seleção, uma vez que a variância genética foi menor que a variância ambiental. De acordo com (ALVES, 2004), valores dessa magnitude indicam que o emprego de métodos simples de melhoramento (ex.: seleção massal) não proporciona ganhos expressivos durante o processo de seleção. 
Quanto à herdabilidade observada para AACPD nos ensaios 01, 02, 03, 04 e 05 foi respectivamente de $0,00 \%, 59,91 \%, 99,31 \%, 99,55 \%$ e $72 \%$. A razão $\mathrm{CVg} / \mathrm{CVe}$ foi de respectivamente $0,00,0,61,6,01,7,45$ e 0,81 . Para os ensaios 01,02 e 05 como apresentaram os valores abaixo de 1 reflete uma condição desfavorável à seleção, uma vez que a variância genética foi menor que a variância ambiental, no entanto, para os ensaios 03 e 04, respectivamente, os valores de herdabilidade e razão $\mathrm{CVg} / \mathrm{CVe}$ para AACPD indicam que existe grande variabilidade genética para esse caráter e que métodos simples, como o de seleção massal, poderiam proporcionar ganhos significativos nos programas de melhoramento genético do maracujazeiro. Esses valores indicam condição favorável de seleção, uma vez que a variância genética supera a ambiental (VENCOVSKY, 1987). As estimativas de herdabilidade para essas variáveis resposta também foram as maiores encontradas, corroborando para os valores da razão $\mathrm{CVg} / \mathrm{CVe}$.

Utilizou-se trinta e duas progênies e verificou-se que a razão $\mathrm{CVg} / \mathrm{CVe}$ foi maior que 1 para as variáveis resposta número total de frutos de primeira $(1,06)$ e produtividade total estimada de frutos de primeira (1,02) (MOREIRA, 2011). Avaliando vinte e seis famílias de irmãos completos, encontrou razão entre coeficiente de variação genético e ambiental (experimental) acima de $1(1,44)$ para massa do fruto em gramas (LINHARES, 2007).

Obteve-se valores para a mesma variável acima de 1 em número de frutos por planta $(1,47)$ e massa de fruto $(1,31)$ (NUNES, 2006).

Tabela 13. Estimativas das variâncias fenotípica (Vf), genotípica (Vg), ambiental (Ve), herdabilidade sentido amplo $\left(\mathrm{h}^{2}\right)$, coeficiente de variação genético $(\mathrm{CVg})$ e razão entre coeficiente e variação genético e ambiental $(\mathrm{CVg} / \mathrm{CVe})$, utilizando-se dados de cinco avaliações de cento e vinte progênies de maracujazeiro-azedo em casa de vegetação, descritos para três variáveis resposta. Estação Biológica - UnB 2012.

\section{Ensaio 01}

\begin{tabular}{|c|c|c|c|}
\hline PROGÊNIES & INCIDÊNCIA & SEVERIDADE & AACPD \\
\hline $\mathrm{h}^{2}$ (média família) & $19,54 \%$ & - & - \\
\hline $\mathbf{C V g}$ & $\mathbf{4 , 9 \%}$ & - & - \\
\hline $\mathbf{C V g} / \mathbf{C V e}$ & $\mathbf{0 , 2 4}$ & - & - \\
\hline
\end{tabular}




\section{Ensaio 02}

\begin{tabular}{|c|c|c|c|}
\hline PROGÊNIES & INCIDÊNCIA & SEVERIDADE & AACPD \\
\hline $\mathrm{h}^{2}$ (média família) & $16,86 \%$ & $32,79 \%$ & $59,91 \%$ \\
\hline $\mathrm{CVg}$ & $2,4 \%$ & $7,47 \%$ & $21,47 \%$ \\
\hline $\mathrm{CVg} / \mathrm{CVe}$ & 0,22 & 0,34 & 0,61 \\
\hline
\end{tabular}

Ensaio 03

\begin{tabular}{|c|c|c|c|}
\hline PROGÊNIES & INCIDÊNCIA & SEVERIDADE & AACPD \\
\hline $\mathrm{h}^{2}$ (média família) & - & $8,6 \%$ & 99,31 \\
\hline $\mathrm{CVg}$ & - & $3,41 \%$ & $35,44 \%$ \\
$\mathrm{CVg} / \mathrm{CVe}$ & - & 0,15 & 6,01 \\
\hline
\end{tabular}

Ensaio 04

\begin{tabular}{|c|c|c|c|}
\hline PROGÊNIES & INCIDÊNCIA & SEVERIDADE & AACPD \\
\hline $\mathrm{h}^{2}$ (média família) & $17,31 \%$ & $31,86 \%$ & $99,55 \%$ \\
\hline $\mathrm{CVg}$ & $1,40 \%$ & $5,72 \%$ & $32,52 \%$ \\
\hline $\mathrm{CVg} / \mathrm{CVe}$ & 0,22 & 0,34 & 7,45 \\
\hline
\end{tabular}

Ensaio 05

\begin{tabular}{|c|c|c|c|}
\hline PROGÊNIES & INCIDÊNCIA & SEVERIDADE & AACPD \\
\hline $\mathrm{h}^{2}$ (média família) & - & $51 \%$ & $72 \%$ \\
\hline $\mathrm{CVg}$ & - & $8,89 \%$ & $23,67 \%$ \\
\hline $\mathrm{CVg} / \mathrm{CVe}$ & - & 0,51 & 0,81 \\
\hline
\end{tabular}


* Médias na coluna seguidas pelas mesmas letras não diferem estatisticamente entre si pelo teste de Scott Knott ao nível de 5\%.

Incidência: porcentagem (frequência) de plantas doentes em uma amostra ou população (AMORIM, 1995).

Severidade: porcentagem da área ou volume de tecido da planta coberto por sintomas é a variável mais utilizada para quantificar doenças foliares (BERGAMIN FILHO \& AMORIM, 1996).

AACPD: Área Abaixo da Curva do Progresso da Doença.

(-) Não foi possível o cálculo das estimativas.

\section{4 - CONCLUSÕES}

Quanto à classificação de notas médias podemos dizer que a maioria das progênies foi altamente suscetível (AS) à bacteriose e apenas três progênies de todo o experimento foram classificadas como suscetíveis (S).

Valores elevados da herdabilidade e razão $\mathrm{CVg} / \mathrm{CVe}$ foram observados para área abaixo da curva do progresso da doença (AACPD), indicando condição favorável de seleção de plantas mais resistentes, utilizando essa característica.

Os resultados mostram baixa variabilidade genética entre as progênies. No entanto, apenas para os ensaios 03 e 04, os valores de herdabilidade e razão CVg/CVe para AACPD indicam que existe grande variabilidade genética para esse caráter. 


\section{REFERÊNCIAS BIBLIOGRÁFICAS}

ALVES, J. C. S. Estimativa de parâmetros genéticos para caracteres de semente e de planta em populações de cenoura (Daucus carota L.) derivadas da cultivar Brasília. Brasília, DF: Universidade de Brasília, 2004. p.68. Dissertação (Mestrado em Ciências Agrárias).

AMORIM, L. Avaliação de Doenças. In: BERGAMIN FILHO, A.; KIMATI, H.; AMORIM, L. (ed.) Manual de Fitopatologia: Princípios e conceitos. São Paulo: Editora Agronômica Ceres Ltda., 1995. v.1, cap.32, p.645-671.

ANGEL, F. O.; FAJARDO, D.; GRUM, M.; TOHME, J.; LOBO, M.; Genetic variation analysis of the genus Passiflora L. using RAPD markers. Dordrecht: Euphytica, 1998. v.101, p. 341-347.

BERGAMIN FILHO, A.; AMORIM, L. Doenças de plantas tropicais: epidemiologia e controle econômico. São Paulo: Agronômica Ceres, 1996. p. 299.

BERGER, R. D. The analysis of the effects of control measures on the development of epidemics. In: Kranz, J. \& Rotem, J. (Eds.) Experimental techniques in plant disease epidemiology. Heidelberg: Springer-Verlag, 1988. p. 137-151.

BOUZA, R. B. Reação em progênies de maracujá-azedo à antracnose, septoriose, cladosporiose e bacteriose em condições de campo e casa de vegetação. Brasília: Universidade de Brasília, 2009.p.160. Dissertação (Mestrado em Fitopatologia).

CASSIANO, A. P. A. A.; LEMOS, E.G.M.; OLIVEIRA, J.C. Avaliação de espécies de Passiflora através de marcadores moleculares RAPD. Genetics and Molecular Biology Suplemento,1998. v.21, n.3, p.214.

COLATTO, U. L. D. Reação de progênies de maracujazeiro azedo à antracnose (Colletotrichum gloeosporioides), à verrugose (Cladosporium herbarum) e à bacteriose (Xanthomonas axonopodis pv. passiflorae). 2010, Xii, $97 \mathrm{f}$. 
CROCHEMORE, M. L. Diversidade genética do maracujazeiro (Passiflora spp.). In: Reunião técnica de pesquisa em maracujazeiro, 3, 2002. Viçosa, Anais...Viçosa. p. 69-74.

CRUZ, C. D. Programa Genes: aplicativo computacional em genética e estatística. Viçosa: UFV, 1997. p.442.

CUNHA, M. A. P. da; BARBOSA, L.V. \& JUNQUEIRA, N.T.V. Aspectos botânicos. In: LIMA, A. de A. (Ed.). Maracujá produção: aspectos técnicos. Embrapa Mandioca e Fruticultura, +Cruz das Almas. Brasília: Embrapa Informação Tecnológica (Frutas do Brasil, 15), 2002. p.15-24.

DIAS, S. C. Morte precoce do maracujazeiro amarelo (Passiflora edulis f. flavicarpa) causada por patógenos que afetam a parte aérea da planta. Brasília: Universidade de Brasília, 1990. 137 f. Dissertação (Mestrado em Fitopatologia).

FALEIRO, F.G.; JUNQUEIRA, N.T.V.; BRAGA, M.F. Germoplasma e melhoramento genético do germoplasma - desafio da pesquisa. In: FALEIRO, F.G.; JUNQUEIRA, N.T.V.; BRAGA, M.F. (Ed.) Maracujá germoplasma e melhoramento genético. Brasília: Embrapa Cerrados, 2005. p. 187-210.

FERREIRA, G. Propagação do maracujazeiro. Belo Horizonte: Informe Agropecuário,2000. v. 21, n. 206, p. 18-24.

RAMALHO, M. A. P.; FERREIRA, D.F; OLIVEIRA, A.C. Experimentação em genética e melhoramento de plantas. Lavras: UFLA, 2000. p.326.

JUNQUEIRA, N. T. V.; BRAGA, M. F.; FALEIRO, F. G.; PEIXOTO, J. R.; BERNACCI, L. C. Potencial de espécies silvestres de maracujazeiro como fonte de resistência a doenças. In: FALEIRO, F. G.; JUNQUEIRA, N. T. V.; BRAGA, M. F. (Ed.). Maracujá: germoplasma e melhoramento genético. Planaltina: Embrapa Cerrados,2005. cap. 4, p. 81-107.

ANJOS, J.R.N.; SILVA, A.P.O.; CHAVES, R.C.; GOMES, A.C. Reação às doenças e produtividade de onze cultivares de maracujá-azedo cultivadas sem agrotóxicos. Pesquisa Agropecuária Brasileira, 2003.v. 38, n. 8 p. 1005-1010. 
LINHALES, H. Seleção em famílias de irmãos completos de maracujazeiro amarelo (Passiflora edulis Sims f. flavicarpa Deg.) no segundo ano de produção. Viçosa, MG: Universidade Federal de Viçosa, 2007. p.84. Dissertação (Mestrado em Fitotecnia).

MALAVOLTA JR.V.A. Bacteriose do maracujazeiro. In: Simpósio Brasileiro Sobre a Cultura do Maracujá. Jaboticabal: Anais, 1998. p.217-229.

MALNATI, W.D.; MORGADO, H.S.; REIFSCHNEIDER, F.J.B. Variabilidade de isolados de Septoria lycopersici em Lycopersicon spp. Brasília: Fitopatologia brasileira, 1993. v. 17, p. 84-86.

MARTINS, I. Reação de progênie s de maracujazeiro-amarelo ao Colletotrichum gloeosporioides e biocontrole da antracnose com Trichoderma spp. Brasília: Universidade de Brasília, 2005. p.137. Dissertação de Mestrado.

MOREIRA, H. S. M. Produtividade, reação a doenças e estimativas de parâmetros genéticos em progênies de maracujazeiro-azedo cultivadas no Distrito Federal. Brasília: Faculdade de Agronomia e Medicina Veterinária, Universidade de Brasília-Brasília, 2011. p. 106 . Dissertação de Mestrado.

NUNES, E. S. Seleção entre e dentro de famílias de irmãos completos de maracujazeiro (Passiflora edulis f. flavicarpa). Viçosa, MG: Universidade Federal de Viçosa, 2006. p.96. Dissertação (Mestrado em Genética e Melhoramento de plantas).

PIO-RIBEIRO, G. \& MARIANO, R.L.R.D. Doenças do maracujazeiro (Passiflora spp.). In: Manual de fitopatologia: doenças das plantas cultivadas. 3.ed. São Paulo: Editora Agronômica Ceres, 1997.v. 2, p. 525-534.

PIOVIANA, A.; PEREIRA, T.N.S.; PEREIRA, M.G.; SOUZA, M.M.; MALDONADO, F.; AMARAL JÚNIOR, A.T. Diversidade entre genótipos de maracujazeiro amarelo (Passiflora edulis f. flavicarpa) e entre espécies de passifloras determinada por marcadores RAPD. Jaboticabal. Revista Brasileira de Fruticultura, 2003. v. 25, p. 489-493. 
REZENDE, J.A.M. Doenças de vírus e micoplasma do maracujazeiro no Brasil. In: SÃO JOSÉ, A.R. (Ed.) Maracujá: produção e mercado. Vitória da Conquista: Universidade Estadual do Sudoeste da Bahia, 1994. p.116-125.

SANTOS FILHO, H.P.; SANTOS, C.C.F. Doenças causadas por fungos. In: SANTOS FILHO, H.P.; JUNQUEIRA, N.T.V. Maracujá: fitossanidade. Brasília: Embrapa Informação Tecnológica, 2003. p. 12-21. (Embrapa Informação Tecnológica. Série Frutas do Brasil, 32).

SCOTT, A.; KNOTT, M. Cluster-analysis method for grouping means in analysis of variance. Washington D.C: Biometrics, 1974. v.30, n.3, p.507-512.

SEIXAS, L.F.Z. Comportamento de espécies e híbridos interespecíficos de maracujazeiro quando inoculados com Xanthomonas campestris pv. passiflorae (Per.) Dye. 1989 Jabuticabal: Unive.rsidade de São Paulo, 1989. 193f. Monografia (Trabalho de Graduação).

SOUSA, M.A.F. Produtividade e reação de progênies de maracujazeiro azedo a doenças em campo e casa de vegetação. Brasília: Universidade de Brasília, 2009. p. 248. Tese (Doutorado em Fitopatologia).

TOCCHINI, R.P.; NISIDA, A.L.A.C.; HASHIZUME, T.; MEDINA, J.C.; TURATTI, J.M. Processamento: produtos, caracterização e utilização. In: Maracujá: cultura, matériaprima, processamento e aspectos econômicos. $2^{\text {a }}$ ed. rev. e ampl. Campinas: ITAL, 1994. p. 161-195. (Série Frutas Tropicais, 9).

VENCOVSKY, R. Herança quantitativa. In: PATERNIANI, E.; VIEGAS, G. P. (coord.). Melhoramento e produção de milho no Brasil. 2 ed. Campinas: Fundação Cargil, 1987. p. 137-214.

VIEIRA, M.L.C.; OLIVEIRA, C.A.; MAYEDA, L.Y.; DORNELAS, M.C.; FUNGARO, M.H.P. Estudo do cariótipo e da variabilidade genética detectada por RAPD em espécies de maracujazeiro (Passiflora L.). Ribeirão Preto: Brazilian Journal of Genetics Suplemento, 1997. v. 20, n. 3, p. 88. 
OLIVEIRA, E.J.; MATTA, F.P.; PÁDUA, J.G.; MONTEIRO, M. Métodos biotecnológicos aplicados ao melhoramento genético do maracujá. In: Faleiro, F.G.; Junqueira, N.T.V.; Braga, M.F. (Eds.) Maracujá: germoplasma e melhoramento genético. Planaltina, DF: Embrapa Cerrados, 2005. p. 411-453.

VIANA, C.A.S. Resistência de genótipos de maracujá-azedo à bacteriose (Xanthomonas axonopodis pv. passiflorae) e à virose do endurecimento do fruto (Cowpea aphid-borne mosaic virus). Brasília: Universidade de Brasília, 2007. 210f. Dissertação (Mestrado em Fitopatologia). 
CAPITULO 2

RESISTÊNCIA DE PROGÊNIES DE MARACUJAZEIRO-AZEDO À SEPTORIOSE, EM CONDIÇÕES DE CASA DE VEGETAÇÃO 


\section{RESUMO}

O maracujazeiro é atacado por diversos patógenos, entre eles o fungo Septoria passiflorae, causador da septoriose. Objetivando-se avaliar a reação de genótipos de maracujá-azedo à septoriose foi conduzido experimento na Estação Biológica da Universidade de Brasília, em blocos casualizados com quatro repetições e seis plantas por parcela, testando-se vinte e quatro progênies. Esse experimento foi conduzido no período de dezembro de 2012 a janeiro de 2013. A inoculação com o patógeno foi feita por aspersão na planta com suspensão contendo concentração de $5.0 \times 10^{6}$ esporos $/ \mathrm{ml}$ produzidos em meio de cultura. Foi utilizado o arranjo experimental de parcelas subdivididas. As parcelas foram formadas por quatro épocas de avaliação e as subparcelas por vinte e quatro progênies. Foram avaliadas as seguintes progênies: FB 200; MSCA Pl.1; MAR 20\#01; MAR 20\#02 FB100 Pl.4; Rubi Gigante; PES 9, PL1; PL2; ECL7 P12; EC3-0; RC3 P1.2; MAR20\#12 P1.2 e P1.3; MAR20\#39; MAR20\#46 Pl.1; MAR20\#46; MAR20\#10 Pl.1; MAR20\#2005 Pl.3; MAR20\#49 Pl.1; MAR20\#10 Pl.2; MAR20\#44 Pl.1 e 3. Foram realizadas quatro avaliações de incidência e severidade, sendo a primeira no $15^{\circ}$ dia após a inoculação e as demais em intervalos de sete dias. Para a quantificação da doença foi utilizada a escala proposta por (DIAS, 1990), com adaptações: (1) - plantas sem sintomas; (2) - lesões esparsas nas folhas tomando até $10 \%$ do limbo foliar; (3) - lesões coalescendo tomando de 10 a $33 \%$ do limbo foliar; (4) - lesões coalescendo tomando mais de $33 \%$ do limbo folear; e (5) - planta com desfolha. A herdabilidade observada para incidência, severidade e AACPD, bem como a razão $\mathrm{CVg} / \mathrm{CVe}$ foram baixas o que reflete uma condição desfavorável à seleção, uma vez que a variância genética foi menor que a variância ambiental. Foi possível observar que apenas uma progênie classificada como altamente suscetível (MAR 20\#46 Pl.1), oito progênies (FB200; MSCA Pl.1; MAR 20\#02; MAR 20\#39; PES 9; MAR 20\#10 Pl.1; MAR 20\#49 Pl.1; e RC3 Pl.2) foram consideradas suscetíveis, doze progênies (MAR 20\#12 Pl.2; MAR 20\#19; MAR 20\#01; MAR 20\#46; FB100 Pl.4; Rubi Gigante; PL.1; MAR 20\#12 Pl.3; MAR $20 \# 44$ Pl.3; MAR 20\#44 Pl.1; e MAR 20\#10 Pl.2) consideradas moderadamente suscetíveis e três progênies (MAR 20\#2005 Pl 3; ECL7 Pl.2 e EC3-0) moderadamente resistentes.

Palavras-chave: passiflora edulis Sims, resistência, septoriose. 


\begin{abstract}
The passion fruit is attacked by many pathogens, including the Septoria passiflorae fungus. In order to analyze the reaction of sour passion fruit genotypes to septoria, an experiment was conducted at Biological Station of the University of Brasília, in randomized blocks with four replications and 6 plants per plot, testing 24 genotypes. This experiment was carried out from December 2012 to January 2013. The pathogen inoculation was carried out by spraying the plant with a suspension containing the concentration of $5.0 \times 10^{6}$ spores $/ \mathrm{ml}$, produced in culture medium. The experimental arrangement used was split plot. The plots were formed by four evaluation periods and the subplots with 24 genotypes. The following genotypes were evaluated: FB 200; MSCA Pl.1; MAR 20\#01; MAR 20\#02; FB100 Pl.4; Rubi Gigante; PES 9; PL1; PL2; ECL7 P12; EC3-0; RC3 Pl.2; MAR20\#12 Pl.2 e Pl.3; MAR20\#39; MAR20\#46 Pl.1; MAR20\#46; MAR20\#10 Pl.1; MAR20\#2005 Pl.3; MAR20\#49 Pl.1; MAR20\#10 Pl.2; MAR20\#44 Pl.1 e 3. The incidence and severity assessments were carried out at intervals of 07 days. A scale from 1 to 5 was used, with (1) - Plants without symptoms, (2) - Injury sparse leaves taking up $10 \%$ of the leaf blade (3) - Injuries coalescing taking between 10-33\% of the leaf blade (4) - coalescing lesions taking more than $33 \%$ of the leaf blade, and (5) - plant with peeling. The heritability observed for incidence, severity and AACPD, and the reason CVg / Cve, were low, reflecting an unfavorable condition to selection, since the genetic variance was lower than the environmental variance. It was observed that only one progeny was classified as highly susceptible (MAR20\#46 Pl.1), 8 progenies (FB200; MSCA Pl.1; MAR 20\#02; MAR20\#39; PES 9; MAR20\#10 Pl.1; MAR20\#49 Pl.1 e RC3 Pl.2) were considered suscetives, 12 progenies (MAR20\#12 Pl.2; MAR20\#19; MAR 20\#01; MAR20\#46; FB100 Pl.4; Rubi Gigante; PL.1; MAR20\#12 Pl.3; MAR20\#44 Pl.3; MAR20\#44 Pl.1; MAR20\#10 Pl.2) considered moderately susceptible and 3 progenies (MAR20\#2005 Pl 3; ECL7 Pl.2 e EC3-0) moderately resistant.
\end{abstract}

Keywords: passiflora edulis Sims, strength, septoria. 


\section{1 - INTRODUÇÃO}

Nos últimos anos, a longevidade do ciclo produtivo do maracujazeiro-azedo (Passiflora edilis Sims e $P$. edulis Sims f. flavicarpa Degener) tem reduzido consideravelmente. Uma das principais causas para essa redução da longevidade é a suscetibilidade das plantas às várias doenças que acometem a cultura. Das enfermidades que atacam o maracujazeiro, as fúngicas são as mais abrangentes, pois existem fungos que podem causar grandes danos tanto no aspecto qualitativo como quantitativo. Essas enfermidades aumentam consideravelmente os custos de produção, devido à necessidade de aplicação de medidas de controle (JUNQUEIRA et al., 2003).

Uma das doenças importantes para o maracujazeiro é a septoriose causada pelo fungo Septoria passiflorae SYDOW, principalmente na região dos cerrados. Esse fungo provoca doenças desde a fase de sementeira até a fase adulta, prejudicando raízes, folhas, caules, flores e frutos. Patógenos que causam doenças no campo também são responsáveis por perdas durante o armazenamento, transporte e comercialização. Esse fungo também causa manchas e queima nas folhas, bem como severa desfolha das plantas (FISCHER; REZENDE, 2008; NASCIMENTO et al., 2000).

Atualmente, tem-se a preocupação de consumidores com a qualidade mercadológica e com a preservação ambiental, o que tem levado ao aumento na procura de produtos sem resíduos de agrotóxicos, que podem ser obtidos através do uso de cultivares resistentes, associado a técnicas de manejo adequadas. Nesse sentido, programas de melhoramento genético visando à resistência às principais doenças do maracujazeiro são muito importantes. Uma importante etapa desses programas de melhoramento é a seleção e identificação de fontes de resistência. Neste trabalho, objetivou-se selecionar genótipos para que possam ser usados como fonte de resistência ao fungo causador da septoriose em maracujazeiro-azedo.

\section{2 - MATERIAL E MÉTODOS}

Foi utilizado um isolado de $S$. passiflorae obtido a partir de plantas severamente afetadas, mantidas em casa de vegetação, na Estação Experimental de Biologia da Universidade de Brasília, no Distrito Federal.

As semeaduras das progênies de maracujazeiro-azedo foram realizadas em bandejas de polietileno expandidos de setenta e duas células (120 ml/célula), com substrato vermicultita (Plantmax). Foram colocadas cinco sementes por célula. 
Com aproximadamente quarenta dias da semeadura, as mudas foram transplantadas para bandejas de poliestireno, uma muda por célula. Após o transplante das mudas, foram feitas adubações de cobertura com nitrogênio amídico (Ureia) na dose aproximada de $6 \mathrm{~g}$ por bandeja na concentração de $10 \mathrm{~g} / \mathrm{l}$ semanalmente.

O delineamento utilizado foi em blocos ao acaso, com quatro repetições e seis plantas úteis por parcela. Foi utilizando o arranjo experimental de parcelas subdivididas, onde as parcelas foram formadas por quatro épocas de avaliação e as subparcelas por vinte e quatro progênies: FB 200; MSCA Pl.1; MAR 20\#01;-MAR 20\#02; FB100 Pl.4; Rubi Gigante; PES 9; PL1; PL2; ECL7 P12; EC3-0; RC3 Pl.2; MAR20\#12 Pl.2 e Pl.3; MAR20\#39; MAR20\#46 Pl.1; MAR20\#46; MAR20\#10 Pl.1; MAR20\#2005 Pl.3; MAR20\#49 Pl.1; MAR 20\#10 Pl.2; MAR20\#44 Pl.1 e 3 obtidas a partir de trabalhos de seleção e cruzamentos desenvolvidos pela Embrapa Cerrados e Universidade de Brasília, levando em consideração os aspectos de produtividade, qualidade dos frutos e resistência aos principais patógenos.

As progênies MAR20\#12 (P1.2 e 3); MAR20\#19; MAR20\#46; MAR20\#46 Pl.1; MAR20\#39; MAR20\#10 Pl.2; MAR20\#2005 Pl.3; MAR20\#49 Pl.1; MAR20\#44 Pl.1 e 3; MAR20\#44 Pl.1 e MAR20\#10 Pl.1 e 2 foram obtidas por seleção massal de plantios comerciais contendo nove materiais superiores, considerando os aspectos de produtividade, qualidade de frutos e resistência aos patógenos, trazidos do município de Araguari, descritos na Tabela 14.

Tabela 14. Progênies cultivadas em pomares comerciais no município de Araguari/MG utilizadas na seleção massal.

\begin{tabular}{|l|l|}
\hline 1 & Maguary "Mesa 1" \\
\hline 2 & Maguary “Mesa 2" \\
\hline 3 & Havaiano \\
\hline 4 & Marília Seleção Cerrado (MSC) \\
\hline 5 & Seleção DF \\
\hline 6 & EC-2-O \\
\hline 7 & $\mathrm{~F}_{1}$ (Marília x Roxo Australiano) \\
\hline 8 & $\mathrm{~F}_{1}[$ Roxo Fiji (introdução das ilhas Fiji) x Marília] \\
\hline 9 & $\begin{array}{l}\mathrm{RC}_{1}\left[\mathrm{~F}_{1}(\text { Marília (seleção da Cooperativa Sul Brasil de Marília }-\mathrm{SP} \text { ) x Roxo }\right. \\
\text { Australiano) x Marília (pai recorrente)]. }\end{array}$ \\
\hline
\end{tabular}

Os materiais denominados, FB 200; MSCA Pl.1; MAR 20\#01;-MAR 20\#02; FB100 Pl.4; Rubi Gigante; PES 9; ECL7 P1.2; EC3-0 e RC3 P1.2 foram obtidos conforme descrito na Tabela 15 . 
Tabela 15. Procedência de progênies de maracujazeiro-azedo avaliados no Distrito Federal, fazenda Água Limpa - UnB, 2012 e 2013.

\begin{tabular}{|c|c|}
\hline PROGENIES & ORIGEM \\
\hline FB200 & Cultivar comercial \\
\hline FB100 & Cultivar comercial \\
\hline MSCA & Marília seleção cerrado \\
\hline PES 9 & $\begin{array}{c}\text { Oriundos da geração F3 de polinização controlada entre as espécies } P \\
\text { edulis e } P \text {. setaceae; }\end{array}$ \\
\hline MAR20\#01 & $\begin{array}{l}\text { Seleção recorrente baseada em família de 1/2 irmãos entre diversos } \\
\text { genótipos de Passiflora edulis }\end{array}$ \\
\hline MAR20\#02 & $\begin{array}{l}\text { Seleção recorrente baseada em família de } 1 / 2 \text { irmãos entre diversos } \\
\text { genótipos de Passiflora edulis }\end{array}$ \\
\hline Rubi Gigante & (Roxo australiano x Marília) \\
\hline ECL -7 & Derivado da cultivar Marília; \\
\hline RC3 & Híbrido de seleção recorrente $(P$. edulis $\times$ P. setacea $)$ \\
\hline EC3-0 & $\begin{array}{l}\text { Híbrido (RC1) de polinização controlada entre as cultivares Marília x } \\
\text { Roxo Australiano retrocruzado para Marília, ou seja, F1 x Marília; }\end{array}$ \\
\hline
\end{tabular}

A inoculação foi feita quando as mudas apresentaram oito a onze folhas verdadeiras. A aplicação de conídios foi feita através de pulverização da suspensão nas faces abaxial e adaxial das folhas. A suspensão inoculada continha esporos do patógeno na concentração de $5,0 \times 10^{6} / \mathrm{ml}$. Foi utilizado um termo-hidrógrafo para registro da temperatura e da umidade relativa do ar, obtendo-se temperaturas médias de 25 a $28{ }^{\circ} \mathrm{C}$, durante o dia, e 19 a $22{ }^{\circ} \mathrm{C}$, durante a noite, e a umidade relativa do ar de $\sim 91 \%$. As mudas foram mantidas em câmara úmida até o aparecimento dos sintomas da doença.

Foram realizadas quatro avaliações, sendo a primeira no $15^{\circ}$ dia após a inoculação e as demais a intervalos de sete dias. Para a quantificação da doença, foram utilizadas duas variáveis, índice de severidade de doença e porcentagem de desfolha por parcela, utilizando a escala proposta por DIAS, (1990), com adaptações de BOUZA, (2009): (1) - Plantas sem sintomas, (2) - Lesões esparsas nas folhas tomando até $10 \%$ do limbo foliar, (3) - Lesões coalescendo tomando de 10 a $33 \%$ do limbo foliar, (4) - Lesões coalescendo tomando mais de $33 \%$ do limbo folear; e (5) - Planta com desfolha.

Em função do índice de severidade de doença, considera-se como plantas resistentes (R), medianamente resistentes (MR), medianamente suscetível (MS), suscetíveis (S) e altamente suscetíveis (AS) foi baseado na nota média, de acordo com a Tabela 16.

Para cada avaliação, calculou-se a porcentagem de plantas resistentes por patógeno. 
Tabela 16. Classificação das plantas inoculadas com Septoria Paseflorae, em função da escala de notas médias.

\begin{tabular}{|c|c|}
\hline NOTAS & CLASSIFICAÇÃO \\
\hline$=0 \mathrm{e}<1$ & Resistentes (R) \\
\hline$\geq 1 \mathrm{e}<2$ & Medianamente resistentes (MR) \\
\hline$\geq 2 \mathrm{e}<3$ & Medianamente suscetíveis (MS) \\
\hline$\geq 3 \mathrm{e}<4$ & Suscetíveis (S) \\
\hline$\geq 4$ & Altamente suscetíveis (AS) \\
\hline
\end{tabular}

A partir dos dados coletados nas quatro avaliações foi obtida a curva de progresso da doença, calculando-se a área abaixo da curva do progresso da doença (AACPD), a fim de avaliar a possibilidade de ser empregada como parâmetro de diferenciação de genótipos quanto à resistência à septoriose.

Para o cálculo da área abaixo da curva de progresso da doença, foi utilizado o programa de computador EXCEL proposta por (SHANER \& FINNEY, 1997) apud (MARTINS, 2005), utilizando-se o programa SISVAR (FERREIRA, 2000).

Os dados obtidos foram submetidos à análise de variância e as médias agrupadas, entre si, pelo teste de Scott-Knott a 5\% de significância (SCOTT \& KNOTT, 1974). Foram também estimados os coeficientes de variação experimental $(\mathrm{CVe})$, genético $(\mathrm{CVg})$ e herdabilidade no sentido amplo $\left(\mathrm{h}^{2}\right)$, para cada uma das características, com auxílio do programa Genes (CRUZ, 2007).

\section{3 - RESULTADOS E DISCUSSÃO}

Apenas uma progênie classificada como altamente suscetível (MAR 20\#46 Pl.1), 8 progênies (FB200; MSCA Pl.1; MAR 20\#02; MAR20\#39; PES 9; MAR20\#10 Pl.1; MAR20\#49 Pl.1 e RC3 Pl.2) foram consideradas suscetíveis, 12 progênies (MAR20\#12 Pl.2; MAR20\#19; MAR 20\#01; MAR20\#46; FB100 Pl.4; Rubi Gigante; PL.1; MAR 20\#12 Pl.3; MAR20\#44 Pl.3; MAR20\#44 Pl.1; MAR20\#10 Pl.2) consideradas moderadamente suscetíveis e 3 progênies (MAR20\#2005 Pl 3; ECL7 Pl.2 e EC3-0) moderadamente resistentes para septoriose nas quatro épocas de avaliação.

Não houve diferenças estatísticas para severidade (percentual da superfície da folha coberta com lesões) à septoriose nas quatro épocas de avaliação. No entanto, no trabalho apresentado utilizando a escala de notas desenvolvidas por JUNQUEIRA et al., (2003) foi possível observar que apenas uma progênie foi classificada como altamente suscetível 
(MAR20\#46), oito progênies foram consideradas suscetíveis, doze progênies consideradas moderadamente suscetíveis e três progênies moderadamente resistentes como mostra a Tabela 17.

Em trabalho apresentado por BOUZA, (2009) com o mesmo patógeno e em casa de vegetação tem-se as seguintes diferenças: as progênies MAR20\#10, MAR20\#12, MAR20\#19, MAR20\#39, MAR20\#44, PES 09, FB100, FB200, EC3-0 e ECL7 apresentaram classificação moderadamente suscetível e para o presente trabalho apresentaram-se como: suscetível, moderadamente suscetível, moderadamente suscetível, suscetível, moderadamente suscetível, suscetível, moderadamente suscetível, suscetível, moderadamente resistente e moderadamente resistente, respectivamente.

Em trabalho apresentado por KUDO, (2012) com septoriose em casa de vegetação as seguintes progênies apresentaram a mesma classificação (suscetível): FB200, PES09, MAR20\#10 e MAR20\#49. As progênies MAR20\#12 e MAR20\#39 foram classificadas como altamente suscetíveis. Já no presente trabalho as progênies citadas anteriormente foram classificadas como moderadamente suscetível e suscetível. Outra comparação, com as progênies MAR20\#19, MAR20\#46 Pl.1, FB 100 Pl.4, ECL7 Pl.2, EC3-0, MAR20\#44 (Pl.1 e 2) e MAR20\#10 Pl.2, neste trabalho foram classificadas como moderadamente suscetível, altamente suscetível, moderadamente suscetível, moderadamente resistente, moderadamente resistente, moderadamente suscetível e moderadamente suscetível, respectivamente.

Os resultados mencionados podem ser explicados uma vez que essas diferenças devem-se ao fator variação entre e dentro das progênies. Por serem materiais procedentes de sementes e não de híbridos uniformes ou linhagens, ainda estão em processo de segregação, além de haver também a variabilidade do patógeno que pode interferir de forma significativa. Também pode ser explicado uma vez que há diferentes isolados de septoriose, que podem ter divergências quanto ao grau de agressividade e ao emprego de diferentes concentrações de inóculo, visto que a concentração do inóculo é variável de trabalho para trabalho. Além disso, as diferentes condições climáticas como, temperatura e umidade relativa do ar, podem influenciar no ritmo de crescimento do patógeno. Elementos como diferentes condições nutricionais das mudas e fatores diversos como diversas idades das plantas inoculadas, número de plantas avaliadas e número de avaliações realizadas também podem provocar divergências representativas. 
Tabela 17. Média de severidade e grau de resistência de septoriose em vinte e quatro progênies de maracujazeiro-azedo, sob condições de casa de vegetação. Estação Biológica UnB 2012.

\begin{tabular}{|c|c|c|}
\hline PROGÊNIES & MÉDIA DE SEVERIDADE & GRAU DE RESISTENNCIA \\
\hline FB 200 & $3,4 \mathrm{a}$ & $\mathrm{S}$ \\
\hline MAR20\#12 Pl.2 & $2,0 \mathrm{a}$ & MS \\
\hline MAR20\#19 & $2,7 \mathrm{a}$ & MS \\
\hline MSCA Pl.1 & $3,1 \mathrm{a}$ & $\mathrm{S}$ \\
\hline MAR20\#01 & $2,0 \mathrm{a}$ & MS \\
\hline MAR20\#02 & $3,6 \mathrm{a}$ & $\mathrm{S}$ \\
\hline MAR20\#46 Pl.1 & $4,2 \mathrm{a}$ & AS \\
\hline MAR20\#39 & $3,4 \mathrm{a}$ & $\mathrm{S}$ \\
\hline MAR20\#46 & $2,6 \mathrm{a}$ & MS \\
\hline FB100 Pl.4 & $2,2 \mathrm{a}$ & MS \\
\hline Rubi Gigante & $2,4 \mathrm{a}$ & MS \\
\hline PES 9 & $3,1 \mathrm{a}$ & $\mathrm{S}$ \\
\hline PL1 & $2,3 \mathrm{a}$ & MS \\
\hline MAR20\#10 Pl.1 & $3,0 \mathrm{a}$ & $\mathrm{S}$ \\
\hline MAR20\#2005 Pl.3 & $1,6 \mathrm{a}$ & MR \\
\hline ECL7 Pl.2 & $1,8 \mathrm{a}$ & MR \\
\hline EC3-0 & $1,7 \mathrm{a}$ & MR \\
\hline MAR20\#49 Pl.1 & $3,2 \mathrm{a}$ & $\mathrm{S}$ \\
\hline MAR20\#12 Pl.3 & $2,3 \mathrm{a}$ & MS \\
\hline RC3 Pl.2 & $3,5 \mathrm{a}$ & $\mathrm{S}$ \\
\hline MAR20\#44 Pl.3 & $2,1 \mathrm{a}$ & MS \\
\hline MAR20\#44 Pl.1 & $2,2 \mathrm{a}$ & MS \\
\hline MAR20\#10 Pl.2 & $2,1 \mathrm{a}$ & MS \\
\hline PL 2 & $2,3 \mathrm{a}$ & MS \\
\hline
\end{tabular}

* Médias na coluna seguidas pelas mesmas letras não diferem estatisticamente entre si pelo teste de Scott Knott ao nível de 5\%.

Os parâmetros genéticos caracterizam uma população e auxiliam na definição das melhores estratégias de seleção e melhoramento visando ao aumento dos ganhos genéticos. No presente trabalho, as estimativas de parâmetros genéticos para as variáveis respostas incidência, severidade e AACPD estão apresentadas na Tabela 18.

A herdabilidade, observada para incidência, severidade e AACPD, foi, respectivamente, de $0,0 \%, 56 \%$ e $58 \%$, o que reflete uma condição desfavorável à seleção, uma vez que a variância genética foi menor que a variância ambiental. A razão $\mathrm{CVg} / \mathrm{CVe}$ para incidência, severidade e AACPD foi, respectivamente, de 0,00, 0,57 e 0,58, refletindo dessa forma uma 
condição desfavorável à seleção, uma vez que a variância genética foi menor que a variância ambiental. Segundo ALVES (2004), valores dessa magnitude indicam que o emprego de métodos simples de melhoramento (ex.: seleção massal) não proporcionará ganhos expressivos durante o processo de seleção. O emprego de métodos de melhoramento baseados no desempenho de famílias é mais adequado do que aqueles que utilizam a seleção com base na performance de plantas individuais.

Com isso, observa-se que houve pouca variância genética devido à grande influência do ambiente.

Tabela 18. Estimativas das variâncias fenotípica (Vf), genotípica (Vg), ambiental (Ve), herdabilidade sentido amplo (ha2), coeficiente de variação genético (CVg) e razão entre coeficiente e variação genético e ambiental ( $\mathrm{CVg} / \mathrm{CVe})$, utilizando-se dados de quatro avaliações de vinte e quatro progênies de maracujazeiro-azedo em casa de vegetação, descritos para três variáveis resposta. Estação Biológica - UnB 2012.

\begin{tabular}{|c|c|c|c|}
\hline \multicolumn{4}{|c|}{ Septoriose } \\
\hline $\begin{array}{c}\text { PARÂMETROS } \\
\text { GENÉTICOS }\end{array}$ & INCIDÊNCIA & SEVERIDADE & AACPD \\
\hline $\mathrm{h}^{2}$ (média família) & - & $56 \%$ & $58 \%$ \\
\hline $\mathrm{CVg}$ & - & $24,58 \%$ & $25,46 \%$ \\
\hline $\mathrm{CVg} / \mathrm{CVe}$ & - & 0,57 & 0,58 \\
\hline
\end{tabular}

* Médias na coluna seguidas pelas mesmas letras não diferem estatisticamente entre si pelo teste de Scott Knott ao nível de 5\%.

Incidência: porcentagem (frequência) de plantas doentes em uma amostra ou população (Amorim, 1995).

Severidade: porcentagem da área ou volume de tecido da planta coberto por sintomas é a variável mais utilizada para quantificar doenças foliares (BERGAMIN FILHO \& AMORIM, 1996).

AACPD: Área Abaixo da Curva do Progresso da Doença.

(-) Não foi possível o cálculo das estimativas. 


\section{4 - CONCLUSÕES}

As progênies estudadas apresentam-se em sua maioria medianamente suscetível (MS) ao fungo. A herdabilidade observada para incidência, severidade e AACPD foi baixa o que reflete uma condição desfavorável à seleção, uma vez que a variância genética foi menor que a variância ambiental. A razão $\mathrm{CVg} / \mathrm{CVe}$ para as mesmas características também foi baixa confirmando a condição desfavorável para a seleção de plantas, logo, baixa variabilidade genética entre as progênies. 


\section{REFERÊNCIAS BIBLIOGRÁFICAS}

BERGAMIN FILHO, A.; AMORIM, L. Doenças de plantas tropicais: epidemiologia e controle econômico. São Paulo: Agronômica Ceres, 1996. p. 299.

BUENO, P.A.O.; PEIXOTO, J.R.; JUNQUEIRA, N.T.V.; MATTOS, J.K.A. Incidência e severidade de septoriose (Septoria passiflorae Sydow) em mudas de 48 genótipos de maracujazeiro-azedo, sob casa de vegetação no Distrito Federal. Biosciience Journal. Uberlândia, 2007. v. 23, n. 2, p. 88-95.

DIAS, S.C. Morte precoce do maracujazeiro-amarelo (Passiflora edulis f. flavicarpa) causada por patógenos que afetam a parte aérea da planta. Brasília: Universidade de Brasília, 1990. 137f. Dissertação (Mestrado em Fitopatologia).

FERREIRA, G. Propagação do maracujazeiro. Belo Horizonte, MG: Informe Agropecuário. v. 21, n. 206, p. 18-24. 2000.

FISCHER, I.H.; REZENDE, J.A.M. Diseases of passion flower (Passiflora spp.). Chaveland: Pest Technology,2008. v.2, n.1, p. 1-19.

GUERRA, N. B; LIVERA, A. V. S. Correlação entre o perfil sensorial e determinações físicas e químicas do abacaxi cv. Pérola. Cruz das Almas: Revista Brasileira de Fruticulura,. v. 21, n.1, p. 32-35. abril. 1990.

JUNQUEIRA, N.T.V.; ANJOS, J.R.N.; SILVA, A.P.O.; CHAVES, R.C.; GOMES, A.C. Reação às doenças e produtividade de onze cultivares de maracujá-azedo cultivadas sem agrotóxicos. Pesquisa Agropecuária Brasileira, 2003. v. 38, n. 8 p. 1005-1010.

KUDO, A.S.; PEIXOTO, J.R.; JUNQUEIRA, N.T.V.; BLUM, L.E.B. Suscetibilidade de genótipos de maracujazeiro azedo à septoriose em casa de vegetação. Revista Brasileira de Fruticultura. Jaboticabal, São Paulo, v. 34, n. 1, p. 200-205. Março. 2012.

NASCIMENTO, A.C.; JUNQUEIRA, N.T.V.; PEIXOTO, J.R.; MANICA, I.; KOSOSK, R.M.; JUNQUEIRA, K.P. Comportamento de frutos de dez genótipos de maracujazeiro-azedo em relação à antracnose (Colletotrichum gloeosporioides ) e à verrugose (Cladosporium spp.) no Distrito Federal. In: CONGRESSO BRASILEIRO DE FRUTICULTURA, 16, 2000, Fortaleza. Resumos... Fortaleza: SBF, 2000.p. 473.

SCOTT, A.; KNOTT, M. Cluster-analysis method for grouping means in analysis of variance. Washington D.C.: Biometrics,1974. v.30, n.3, p.507-512. 
CAPITULO 3

DESEMPENHO PRODUTIVO DE QUARENTA E OITO PROGÊNIES DE MARACUJAZEIRO-AZEDO NO DISTRITO FEDERAL 


\section{RESUMO}

A cultura do maracujá lança o Brasil à posição de grande produtor mundial. Entretanto, essa cultura ainda enfrenta problemas como carência de materiais genéticos com alta produtividade, qualidade dos frutos, resistência a fitopatógenos e pequena longevidade da lavoura, em razão, principalmente, da falta de trabalhos de pesquisa nas diversas áreas do conhecimento e especialmente com melhoramento genético. Com a finalidade de contribuir para o desenvolvimento de cultivares mais promissoras de maracujá, esse trabalho teve como objetivo avaliar o desempenho agronômico de quarenta e oito progênies de maracujazeiroazedo no Distrito Federal, bem como estimar parâmetros genéticos para serem utilizados em programas de melhoramento genético. Foram utilizadas quarenta e oito progênies, num delineamento de blocos casualizados, com cinco plantas úteis por parcela e quatro repetições. As progênies utilizadas foram: Gig. Amar P1.2; FB200; Rosa Int. Pl.1; EC3-0 1; MSCA; MSCA Pl.1; MSCA Pl.2; Gig. Amar. Pl.1; PES 9; Rosa Int.Pl.3; Rosa Claro Pl.3; Rosa Claro Pl.1; Rubi Gig. Pl.1; AR 2; ECL -7;PA 01; RC3; Rosa Int. Pl.2; Rosa Claro 2; Rubi. Gig. Pl.2; EC3-0; AP1; ECRAM Pl.2; ECRAM Pl.3; Gig.Amar.Pl.3; MAR20\#44; MAR20\#44 Pl.1; MAR20\#24 Pl.1; MAR20\#24 P1.2; MAR20\#10; MAR20\#12 P1.1; MAR20\#12 P1.2; MAR20\#15; MAR20\#21; MAR20\#19; MAR20\#41; MAR20\#34; MAR20\#34 P1.7; MAR20\#39; MAR20\#46 Pl.1; MAR20\#46 Pl.2; MAR20\#46 Pl.3; MAR20\#2005 Pl.1; MAR20\#2005 Pl.2; MAR20\#2005 Pl.3; MAR20\#2005 Pl.4; $20 \# 34$ F2; e GAZ Pl.1. O experimento foi instalado no campo em outubro de 2011, com um total de 1.190 plantas. As características que foram avaliadas após trinta e duas colheitas: produtividade estimada $(\mathrm{kg} / \mathrm{ha})$, número total de frutos por hectare, massa média de frutos $(\mathrm{g})$ e classificação dos frutos quanto ao diâmetro equatorial $(\mathrm{mm})$ em três categorias (Primeira, 1B e 1A). A maior produtividade e a maior quantidade de frutos por hectare para frutos de Primeira foram verificadas nas progênies MAR20\#2005 P1.2 e para os frutos 1B foi a MAR20\#44 Pl.1. Em frutos de Primeira, a progênie MSCA obteve a maior massa média total e massa média na classificação de Primeira. Valores elevados da herdabilidade $(75,27 \%)$ e razão CVg /Cve $(0,87)$ foram observados para o peso médio de $1 \mathrm{~A}$.

Palavras-chave: passiflora edulis, produtividade, parâmetros genéticos. 


\begin{abstract}
In the national fruit production, we found some fruit that launch Brazil as a major world producer position, highlighting the passion fruit. However, this culture still faces problems such as lack of genetic materials with high yield, fruit quality, resistance to pathogens and low longevity of the crop, due mainly to the lack of research in the various areas of knowledge and especially breeding. It appears that the culture of passion fruit requires continuous genetic improvement work, since there is little passion fruit cultivars available to Brazilian producers and productivity are still considered low. It was used 48 progenies in a randomized block design, with five plants per plot and four replications. The progenies used were: Gig. Amar Pl.2; FB200; Rosa Int. Pl.1; EC3-0 1; MSCA; MSCA Pl.1; MSCA Pl.2; Gig. Amar. Pl.1; PES 9; Rosa Int.Pl.3; Rosa Claro Pl.3; Rosa Claro Pl.1; Rubi Gig. Pl.1; AR 2; ECL -7; PA 01; RC3; Rosa Int. P1.2; Rosa Claro 2; Rubi. Gig. P1.2; EC3-0; AP1; ECRAM P1.2; ECRAM P1.3; Gig.Amar.Pl.3; MAR20\#44; MAR20\#44 Pl.1; MAR20\#24 Pl.1; MAR20\#24 Pl.2; MAR20\#10; MAR20\#12 Pl.1; MAR20\#12 Pl.2; MAR20\#15; MAR20\#21; MAR20\#19; MAR20\#41; MAR20\#34; MAR20\#34 Pl.7; MAR20\#39; MAR20\#46 Pl.1; MAR20\#46 Pl.2; MAR20\#46 P1.3; MAR20\#2005 Pl.1; MAR20\#2005 P1.2; MAR20\#2005 P1.3; MAR20\#2005 P1.4; 20\#34 F2; GAZ P1.1. The experiment was conducted in the field in October 2011, with a total of 1,190 plants. The features analyzed after twenty harvests were: estimated productivity ( $\mathrm{kg} / \mathrm{ha}$ ), total number of fruit per hectare, average fruit weight $(\mathrm{g})$, regarding the classification of fruit equatorial diameter in three categories. The highest and the greatest amount of fruit per hectare for First fruits were checked in MAR20 \# 2005 and Pl.2 progenies. For fruit 1B was the MAR20 \# 44 Pl.1. In fruits of First the progeny MSCA had the highest average of total mass and average mass in the First rating. High values of heritability (75.27\%) and reason CVg / Cve (0.87) were observed for the average weight of $1 \mathrm{~A}$.
\end{abstract}

Keywords: passiflora edulis, productivity, genetic parameters. 


\section{1 - INTRODUÇÃO}

A fruticultura vem tendo destaque atualmente no sistema agroalimentar e inúmeras transformações estão ocorrendo no mercado interno e externo, agregando valor e promovendo o desenvolvimento de diversas regiões do país. Estima-se que a metade da produção brasileira seja utilizada na fabricação de suco concentrado congelado e a outra metade para o consumo in natura.

Ao longo dos anos, a cultura tem-se mostrado uma alternativa de renda a mais para pequenos e médios produtores rurais, devido ao valor dos frutos comercializados. A produção brasileira de maracujá possui basicamente dois destinos: a indústria, principalmente a de extração de polpa para fabricação de suco, e o consumo in natura com distribuição pelo mercado atacadista das centrais de abastecimento (Ceasa). O suco e a polpa são utilizados no preparo de diversos produtos, entre os quais podem ser citados bebidas carbonatadas, bebidas mistas, xaropes, geleias, laticínios, sorvetes e alimentos enlatados (TEIXERA, 2011).

Atualmente, o maracujazeiro vem sendo plantado em quase todo o território brasileiro, destacando-se os seguintes estados produtores: Bahia, Sergipe, São Paulo, Pará e Minas Gerais. Proporcionando economia e renda em muitos municípios, com forte apelo social, já que se destaca como uma cultura com uso intensivo de mão de obra (FOLEGATTI, 2001).

Originário da América Tropical, o maracujá é largamente cultivado e processado em todo o mundo. África do Sul, Sri Lanka, Austrália, Quênia, Colômbia, Peru, Equador, Venezuela, Costa Rica, entre outros, são exemplos de países produtores, sendo o Brasil, o maior produtor mundial (SEAGRI, 2013).

De acordo com FALEIRO et al., (2005), Passiflorara edulis Sims. (maracujá-azedo) e Passiflora alata Curtis (maracujá-doce) são as espécies mais cultivadas, sendo estimado que essas duas espécies ocupem mais de $90 \%$ da área cultivada no mundo.

O Brasil é o maior produtor mundial de maracujá (LIMA et al., 2006). A área de produção nacional em 2007 foi de 46.866 ha, sendo o total dessa área aproximadamente 30\% superior ao ano de 2005, em que se produziu maracujá em trinta e seis mil hectares. (IBGE, 2013). O maracujá é uma das culturas que contribuem para essa condição do Brasil de produtor mundial de frutas, com produtividade média de 14,7 t/ha em 2010 e a área produzida nacionalmente no mesmo ano de 62.200 hectares resultando em 920.000 toneladas (IBGE, 2013). A produtividade média do maracujazeiro nos últimos anos variou de doze a quinze toneladas por hectare, havendo potencial para produção de trinta a trinta e cinco toneladas por 
hectare (SILVA et al., 2009). Progênies elites, desenvolvidas em ações de pesquisa, chegam a produzir mais de 50t/ha/ano (FALEIRO et al., 2008).

A produção da fruta destaca-se nas regiões Nordeste, Sudeste e Norte do Brasil. A Bahia é o principal produtor, com 317.475 toneladas em 23.227 hectares, seguida pelo Ceará, com 129.001 toneladas produzidas em 5.579 hectares. Em terceiro lugar, em produção nacional, aparece o estado de Sergipe com 44.486 toneladas em 4.709 hectares (IBGE, 2011). Na região Sudeste, o maracujazeiro é uma das oito espécies frutíferas mais cultivadas no sistema extensivo, sendo precedido apenas pelas culturas da laranja, banana, limão, manga, tangerina, abacaxi e uva (SOUZA et al., 2008).

LIMA \& BORGES, (2002) classificam os fatores externos e internos aqueles que influenciam o crescimento e a produção do maracujazeiro. Os fatores internos são relacionados com características genéticas da planta, enquanto os externos se referem às condições edáficas, ambientais, agentes bióticos e à ação do homem que interfere nesses fatores. JUNQUEIRA et al., (1999) citam, dentre outros fatores responsáveis pela baixa produtividade observada na cultura, o cultivo de variedades ou linhagens inadequadas.

Segundo DURIGAN et al., (2004) não existem normas ou regulamentos técnicos oficiais para a qualidade dos frutos do maracujá, apenas padrões relacionados ao diâmetro, peso, cor, textura, teor de sólidos solúveis e acidez. Outro índice, citado por esses autores, é a intensidade de coloração roxa ou amarela da casca: verde-maduro (coloração totalmente verde), meio maduros (cerca de $60 \%$ da casca verde) e frutos maduros (casca com coloração totalmente amarela ou roxa).

Diante do exposto, a seleção de cultivares de maracujazeiro-azedo que apresentem boa produtividade e qualidade de frutos é de fundamental importância para o desenvolvimento da cultura no país. Seguindo esse propósito, o presente trabalho objetivou avaliar o desempenho agronômico e produtivo de quarenta e oito progênies de maracujazeiro-azedo cultivados no Distrito Federal, visando ao uso dos mesmos em programas de melhoramento genético dessa cultura.

\section{2 - MATERIAL E MÉTODOS}

O experimento foi realizado na fazenda Água Limpa (FAL), pertencente à Universidade de Brasília (UnB), situada na Vargem Bonita, $25 \mathrm{~km}$ ao sul do Distrito Federal, com latitude de $16^{\circ}$ Sul, longitude de $48^{\circ}$ Oeste e $1.100 \mathrm{~m}$ de altitude. O clima da região é do tipo $\mathrm{AW}$, 
caracterizado por chuvas concentradas no verão, de outubro a abril, e invernos secos de maio a setembro (MELO, 1999).

Tabela 19. Dados meteorológicos do período do experimento em campo na fazenda Água Limpa (FAL): Out-2011 a Ago-2013.

\begin{tabular}{|c|c|c|c|c|c|c|c|c|}
\hline \multicolumn{9}{|c|}{ Out-Dez 2011} \\
\hline Dia & Prec. & T med & $T \max$ & $\mathbf{T}$ min & UR med & UR max & UR min & Classe A \\
\hline & $\mathrm{mm}$ & $\mathrm{oC}$ & $\mathrm{oC}$ & $\mathrm{oC}$ & $\%$ & $\%$ & $\%$ & $\mathrm{~mm}$ \\
\hline Média & - & 20,4 & 27,1 & 15,9 & 81,4 & 97,3 & 52,6 & - \\
\hline Total & 421,6 & - & - & - & - & - & - & - \\
\hline Máximo & 63,4 & 23,3 & 32,4 & 18,9 & 95,1 & 99,2 & 80,2 & - \\
\hline Mínimo & 0,0 & 15,8 & 18,6 & 11,2 & 48,1 & 86,4 & 21,5 & - \\
\hline Média & - & 20,4 & 26,6 & 15,3 & 81,0 & 97,6 & 52,5 & - \\
\hline Total & 269,6 & - & - & - & - & - & - & - \\
\hline Máximo & 77,4 & 22,7 & 31,2 & 18,1 & 95,1 & 99,1 & 86,7 & - \\
\hline Mínimo & 0,0 & 16,1 & 18,1 & 13,0 & 61,6 & 92,2 & 33,3 & - \\
\hline Média & - & 20,8 & 26,6 & 17,2 & 84,6 & 98,2 & 56,5 & - \\
\hline Total & 433,8 & - & - & - & - & - & - & - \\
\hline Máximo & 57,0 & 22,5 & 29,9 & 19,0 & 95,1 & 99,0 & 85,1 & - \\
\hline Mínimo & 0,0 & 18,8 & 21,3 & 14,5 & 71,0 & 95,9 & 37,9 & - \\
\hline \multicolumn{9}{|c|}{ Jan-Dez 2012} \\
\hline Média & - & 20,3 & 26,0 & 16,4 & 85,0 & 98,3 & 57,5 & 7,5 \\
\hline Total & 243,4 & - & - & - & - & - & - & 231,7 \\
\hline Máximo & 36,4 & 22,4 & 29,6 & 18,4 & 95,6 & 99,0 & 81,8 & 60,5 \\
\hline Mínimo & 0,0 & 18,0 & 20,6 & 14,1 & 75,9 & 97,6 & 39,5 & $-16,5$ \\
\hline Média & - & 20,8 & 27,8 & 15,2 & 80,0 & 98,2 & 49,3 & 4,8 \\
\hline Total & 196,4 & - & - & - & - & - & - & 140,1 \\
\hline Máximo & 64,6 & 22,5 & 31,7 & 17,4 & 93,1 & 99,2 & 74,9 & 9,7 \\
\hline Mínimo & 0,0 & 18,5 & 22,0 & 12,7 & 68,6 & 96,4 & 30,9 & 1,1 \\
\hline Média & - & 21,1 & 28,7 & 15,6 & 78,5 & 97,5 & 46,2 & 5,1 \\
\hline Total & 131,8 & - & - & - & - & - & - & 157,1 \\
\hline Máximo & 22,8 & 23,0 & 31,6 & 17,9 & 92,9 & 99,1 & 64,5 & 8,4 \\
\hline Mínimo & 0,0 & 18,4 & 24,8 & 10,6 & 57,9 & 92,9 & 25,2 & 1,1 \\
\hline Média & - & 21,2 & 28,6 & 15,6 & 79,4 & 98,0 & 46,0 & 4,5 \\
\hline Total & 76,4 & - & - & - & - & - & - & 135,2 \\
\hline Máximo & 23,6 & 22,8 & 30,7 & 18,5 & 89,6 & 99,1 & 68,1 & 9,6 \\
\hline Mínimo & 0,0 & 19,5 & 25,4 & 11,4 & 67,3 & 95,9 & 26,0 & 1,1 \\
\hline Média & - & 18,4 & 25,6 & 12,5 & 81,2 & 98,1 & 51,5 & 3,2 \\
\hline Total & 59,4 & - & - & - & - & - & - & 100,0 \\
\hline Máximo & 35,0 & 20,2 & 29,7 & 16,4 & 90,7 & 99,4 & 73,1 & 7,3 \\
\hline Mínimo & 0,0 & 16,0 & 20,4 & 9,3 & 73,5 & 94,7 & 31,2 & 0,7 \\
\hline Média & - & 18,7 & 26,8 & 11,6 & 76,2 & 98,3 & 43,7 & 4,0 \\
\hline Total & 16,2 & - & - & - & - & - & - & 120,2 \\
\hline Máximo & 8,2 & 20,7 & 29,0 & 15,4 & 83,4 & 99,5 & 52,7 & 8,7 \\
\hline Mínimo & 0,0 & 16,1 & 24,7 & 7,7 & 65,9 & 95,2 & 32,0 & 1,5 \\
\hline Média & - & 17,6 & 26,7 & 9,0 & 66,4 & 94,8 & 34,9 & 4,4 \\
\hline
\end{tabular}




\begin{tabular}{|c|c|c|c|c|c|c|c|c|}
\hline Total & 1,0 & - & - & - & - & - & - & 137,2 \\
\hline Máximo & 0,2 & 19,8 & 29,2 & 14,3 & 82,7 & 98,8 & 59,7 & 6,6 \\
\hline Mínimo & 0,0 & 16,1 & 22,2 & 4,7 & 52,8 & 88,6 & 19,3 & 0,7 \\
\hline Média & - & 18,6 & 26,9 & 10,2 & 56,4 & 86,1 & 30,0 & 5,5 \\
\hline Total & 0,0 & - & - & - & - & - & - & 170,3 \\
\hline Máximo & 0,0 & 21,7 & 30,6 & 14,6 & 65,7 & 97,9 & 43,0 & 7,3 \\
\hline Mínimo & 0,0 & 16,8 & 24,4 & 6,3 & 42,4 & 71,4 & 21,8 & 2,6 \\
\hline Média & - & 21,5 & 30,7 & 12,5 & 55,1 & 87,2 & 27,9 & 6,3 \\
\hline Total & 26,4 & - & - & - & - & - & - & 188,5 \\
\hline Máximo & 19,4 & 25,1 & 34,8 & 18,1 & 80,2 & 98,4 & 47,1 & 9,0 \\
\hline Mínimo & 0,0 & 19,0 & 27,3 & 7,9 & 42,3 & 75,9 & 16,0 & 0,5 \\
\hline Média & - & 22,2 & 31,1 & 13,8 & 61,9 & 91,8 & 31,3 & 6,5 \\
\hline Total & 74,4 & - & - & - & - & - & - & 202,0 \\
\hline Máximo & 41,6 & 25,1 & 34,9 & 18,5 & 84,1 & 99,2 & 61,4 & 11,6 \\
\hline Mínimo & 0,0 & 18,8 & 25,1 & 8,6 & 42,0 & 77,2 & 13,7 & 0,8 \\
\hline Média & - & 21,4 & 27,4 & 17,5 & 84,5 & 98,6 & 55,6 & 3,8 \\
\hline Total & 374,4 & - & - & - & - & - & - & 115,0 \\
\hline Máximo & 79,0 & 23,2 & 30,3 & 19,9 & 92,9 & 99,4 & 73,4 & 7,7 \\
\hline Mínimo & 0,0 & 20,1 & 25,1 & 16,0 & 78,0 & 95,3 & 44,7 & 0,2 \\
\hline Média & - & 21,7 & 29,5 & 15,9 & 78,8 & 98,2 & 46,1 & 5,4 \\
\hline Total & 136,0 & - & - & - & - & - & - & 166,1 \\
\hline Máximo & 25,6 & 23,9 & 32,4 & 19,2 & 88,9 & 99,5 & 62,3 & 9,0 \\
\hline Mínimo & 0,0 & 19,9 & 25,0 & 13,0 & 66,1 & 95,6 & 24,2 & 1,2 \\
\hline \multicolumn{9}{|c|}{ Jan-Ago 2013} \\
\hline Média & - & 21,1 & 26,8 & 17,3 & 84,4 & 98,4 & 57,9 & 4,2 \\
\hline Total & 368,8 & - & - & - & - & - & - & 130,2 \\
\hline Máximo & 57,0 & 23,2 & 31,5 & 19,6 & 95,2 & 99,5 & 84,2 & 9,7 \\
\hline Mínimo & 0,0 & 18,1 & 20,0 & 13,5 & 63,4 & 95,0 & 27,5 & 0,0 \\
\hline Média & - & 21,8 & 29,3 & 15,7 & 76,8 & 98,1 & 44,8 & 5 \\
\hline Total & 128,2 & - & - & - & - & - & - & 140,2 \\
\hline Máximo & 53,4 & 23,4 & 31,8 & 18,2 & 90,7 & 99,4 & 60,3 & 9,1 \\
\hline Mínimo & 0 & 19,5 & 25,8 & 12,1 & 65,1 & 95,4 & 30,6 & 0,4 \\
\hline Média & - & 21,7 & 28,5 & 17,1 & 82,8 & 98,6 & 52,1 & 4,5 \\
\hline Total & 196,2 & - & - & - & - & - & - & 139,4 \\
\hline Máximo & 51,4 & 23,6 & 31,9 & 19,3 & 95,9 & 99,5 & 82,3 & 9,0 \\
\hline Mínimo & 0,0 & 19,0 & 22,0 & 13,3 & 71,5 & 97,8 & 36,7 & 0,9 \\
\hline Média & - & 20,0 & 27,1 & 14,5 & 82,7 & 98,9 & 52,6 & 3,5 \\
\hline Total & 132,8 & - & - & - & - & - & - & 106,3 \\
\hline Máximo & 49,0 & 22,0 & 29,6 & 18,5 & 96,0 & 99,5 & 69,7 & 7,9 \\
\hline Mínimo & 0,0 & 17,4 & 24,3 & 10,2 & 74,4 & 97,5 & 41,3 & 0,8 \\
\hline Média & - & 18,9 & 27,6 & 11,3 & 75,8 & 98,5 & 41,8 & 4,1 \\
\hline Total & 36,2 & - & - & - & - & - & - & 126,7 \\
\hline Máximo & 31,8 & 20,7 & 29,5 & 14,9 & 94,2 & 99,7 & 71,8 & 7,0 \\
\hline Mínimo & 0,0 & 17,0 & 21,5 & 8,8 & 67,2 & 94,0 & 23,5 & 1,1 \\
\hline Média & - & 18,9 & 27,6 & 11,3 & 75,8 & 98,5 & 41,8 & 4,1 \\
\hline Total & 36,2 & - & - & - & - & - & - & 126,7 \\
\hline
\end{tabular}




\begin{tabular}{|c|c|c|c|c|c|c|c|c|}
\hline Máximo & 31,8 & 20,7 & 29,5 & 14,9 & 94,2 & 99,7 & 71,8 & 7,0 \\
\hline Mínimo & 0,0 & 17,0 & 21,5 & 8,8 & 67,2 & 94,0 & 23,5 & 1,1 \\
\hline Média & - & 18,0 & 27,2 & 9,9 & 67,9 & 95,3 & 36,0 & 4,6 \\
\hline Total & 0,0 & - & - & - & - & - & - & 142,5 \\
\hline Máximo & 0,0 & 19,7 & 30,7 & 13,2 & 80,5 & 99,2 & 55,9 & 6,0 \\
\hline Mínimo & 0,0 & 15,9 & 23,4 & 6,9 & 55,9 & 90,1 & 23,8 & 1,5 \\
\hline Média & - & 19,0 & 28,6 & 9,4 & 57,5 & 89,5 & 27,9 & 5,9 \\
\hline Total & 0,0 & - & - & - & - & - & - & 182,2 \\
\hline Máximo & 0,0 & 21,0 & 31,2 & 15,2 & 64,8 & 95,0 & 37,8 & 7,9 \\
\hline Mínimo & 0,0 & 16,3 & 26,3 & 4,9 & 46,5 & 72,0 & 17,3 & 3,8 \\
\hline
\end{tabular}

O experimento foi instalado em solo Latossolo Vermelho-Amarelo, fase argilosa, profundo, com boa drenagem. A análise de solo apresentou os seguintes resultados: $\mathrm{Al}(0,05$ meq); $\mathrm{Ca}+\mathrm{Mg}$ (1,9 meq); $\mathrm{P}(4,5$ ppm); K (46 ppm); pH 5,4 e saturação de $\mathrm{Al} 4 \%$. A calagem foi feita em área e $1 \mathrm{Kg}$ de superfosfato simples foi incorporado por cova.

A suplementação de água foi feita via sistema de irrigação, sendo realizada da seguinte forma: sete horas de irrigação e um turno de dois dias com média de 3 litros por metro linear por hora.

Para o plantio, foram aplicados $700 \mathrm{~g}$ de superfosfato simples e $200 \mathrm{~g}$ de calcário dolomítico por cova, além de quatro adubações com intervalo de quinze dias com $200 \mathrm{~g}$ de sulfato de amônio e $100 \mathrm{~g}$ de cloreto de potássio.

Foram estudadas quarenta e oito progênies (croqui do experimento em anexo), num delineamento de blocos casualizados, com cinco plantas por parcela e quatro repetições. As progênies utilizadas foram: Gig. Amar. Pl.2; FB200; Rosa Int. Pl.1; EC3-0 Pl.1; MSCA; MSCA P1.1; MSCA P1.2; Gig. Amar. Pl.1; PES 9; Rosa Int.P1.3; Rosa Claro Pl.3; Rosa Claro Pl.1; Rubi Gig. Pl.1; AR 2; ECL -7; PA 01; RC3; Rosa Int. Pl.2; Rosa Claro P1.2; Rubi. Gig. P1.2; EC3-0; AP1; ECRAM Pl.2; ECRAM P1.3; Gig.Amar. Pl.3; MAR20\#44; MAR20\#44 Pl.1; MAR20\#24 Pl.1; MAR20\#24 Pl.2; MAR20\#10; MAR20\#12 Pl.1; MAR20\#12 Pl.2; MAR20\#15; MAR20\#21; MAR20\#19; MAR20\#41; MAR20\#34; MAR20\#34 P1.7; MAR20\#39; MAR20\#46 Pl.1; MAR20\#46 Pl.2; MAR20\#46 Pl.3; MAR20\#2005 Pl.1; MAR20\#2005 Pl.2; MAR20\#2005 Pl.3; MAR20\#2005 P1.4; $20 \# 34$ F2; e GAZ Pl.1. Essas progênies foram desenvolvidas a partir de trabalhos de pesquisa desenvolvidos pela Universidade de Brasília - UnB e Embrapa Cerrados. Têm origem de hibridações intraespecíficas e interespecíficas e também de materiais oriundos de seleção massal feita em pomares produtivos da região Sudeste do Brasil. 
Os materiais MAR20\#44; MAR20\#24 (Pl 1 e 2); MAR20\#12 (Pl 1 e 2); MAR20\#21; MAR20\#19; MAR20\#41; MAR20\#39; MAR20\#46 (Pl 1, 2 e 3) e MAR20\#2005 (Pl 1, 2, 3 e 4) foram obtidos por seleção massal de plantios comerciais contendo nove materiais superiores, considerando os aspectos de produtividade, qualidade de frutos e resistência aos patógenos, trazidos do município de Araguari, descritos na Tabela 20.

Tabela 20. Progênies cultivadas em pomares comerciais no município de Araguari/MG utilizados na seleção massal.

\begin{tabular}{|l|l|}
\hline 1 & Maguary "Mesa 1" \\
\hline 2 & Maguary "Mesa 2" \\
\hline 3 & Havaiano \\
\hline 4 & Marília Seleção Cerrado (MSC) \\
\hline 5 & Seleção DF \\
\hline 6 & EC-2-O \\
\hline 7 & $\mathrm{~F}_{1}$ (Marília x Roxo Australiano) \\
\hline 8 & $\mathrm{~F}_{1}[$ Roxo Fiji (introdução das ilhas Fiji) x Marília] \\
\hline 9 & $\begin{array}{l}\mathrm{RC}_{1}\left[\mathrm{~F}_{1}(\text { Marília (seleção da Cooperativa sul Brasil de Marília }-\mathrm{SP}) \text { x Roxo }\right. \\
\text { Australiano) x Marília (pai recorrente)]. }\end{array}$ \\
\hline
\end{tabular}

As progênies MAR20\#10 e MAR 20\#15 foram obtidas através de sementes coletadas do campo experimental da fazenda Água Limpa (FAL) - UnB- 2011.

Os materiais denominados FB-200, Rosa Int., EC 3-0 Pl.1, MSCA, PES 9, Rosa Claro, Rubi Gig, AR 2, ECL -7, PA 01, RC3, AP1 e ECRAM 2 foram obtidos conforme descrito na Tabela 21.

Tabela 21. Procedência de progênies de maracujazeiro-azedo avaliados no Distrito Federal, fazenda Água Limpa (FAL) - UnB, 2012 e 2013.

\begin{tabular}{|c|c|}
\hline PROGÊNIES & ORIGEM \\
\hline Gig. Amar & $\mathrm{F}_{1}$ (Redondão X MSC) \\
\hline FB200 & Cultivar comercial \\
\hline Rosa Int. & Seleção recorrente baseada na família de meio irmãos. \\
\hline EC 3-0 1 & $\begin{array}{l}\text { Híbrido }\left(\mathrm{RC}_{1}\right) \text { de polinização controlada entre as cultivares Marília x Roxo } \\
\text { Australiano retrocruzado para Marília, ou seja } \mathrm{F}_{1} \text { x Marília }\end{array}$ \\
\hline MSCA & Marília seleção cerrado \\
\hline PES 9 & $\begin{array}{c}\text { Oriundos da geração } \mathrm{F}_{3} \text { de polinização controlada entre as espécies } P \text {. edulis } \\
\text { e } P \text {. setaceae }\end{array}$ \\
\hline Rosa Claro & Seleção recorrente baseada na família de meio irmãos \\
\hline MAR 20\#01 & $\begin{array}{l}\text { Seleção recorrente baseada em família de } 1 / 2 \text { irmãos entre diversos } \\
\text { genótipos de Passiflora edulis }\end{array}$ \\
\hline MAR 20\#02 & $\begin{array}{l}\text { Seleção recorrente baseada em família de } 1 / 2 \text { irmãos entre diversos } \\
\text { genótipos de Passiflora edulis }\end{array}$ \\
\hline Rubi Gigante & (Roxo australiano x Marília) \\
\hline AR 2 & Seleção individual de plantas resistentes à antracnose de uma população de \\
\hline
\end{tabular}




\begin{tabular}{|c|c|}
\hline & Roxo Australiano \\
\hline ECL -7 & Derivado da cultivar Marília \\
\hline PA 01 & Seleção recorrente baseada na família de meio irmãos \\
\hline RC3 & Híbrido de seleção recorrente $($ P. edulis x P. setacea) \\
\hline EC3-0 & $\begin{array}{c}\text { Híbrido (RC1) de polinização controlada entre as cultivares Marília x Roxo } \\
\text { Australiano retrocruzado para Marília, ou seja, F1 x Marília }\end{array}$ \\
\hline AP1 & $\begin{array}{c}\text { Cultivar obtida do cruzamento entre tipos de maracujá-amarelo de alta } \\
\text { produtividade, selecionados em pomar comercial }\end{array}$ \\
\hline ECRAM 2 & Híbrido entre roxo australiano $(P$. edulis $)$ x P. edulis f. flavicarpa \\
\hline
\end{tabular}

As mudas foram obtidas por meio de semeadura em bandejas com setenta e duas células com $125 \mathrm{ml}$ de substrato vermiculita em junho de 2012, sob casa de vegetação localizada na Estação Biológica - UnB. As mudas foram transplantadas para o campo em outubro de 2011, com adubação de $700 \mathrm{~g}$ de superfosfato simples por cova. $\mathrm{O}$ espaçamento utilizado foi de 2,8 $\mathrm{m}$ entre linhas e $3 \mathrm{~m}$ entre plantas, totalizando 1.190 plantas por hectare.

A suplementação de água foi feita via sistema de irrigação, sendo realizada da seguinte forma: sete horas de irrigação e um turno de dois dias com média de três litros por metro linear por hora.

Para o plantio, foram aplicados $700 \mathrm{~g}$ de superfosfato simples e $200 \mathrm{~g}$ de calcário dolomítico por cova, além de quatro adubações com intervalo de quinze dias com $200 \mathrm{~g}$ de sulfato de amônio e $100 \mathrm{~g}$ de cloreto de potássio. Após o plantio foram realizadas adubações com periodicidade de quinze em quinze dias. Os níveis de adubação de potássio e nitrogênio foram: $100 \mathrm{~g}$ de sulfato de amônio (20 g de nitrogênio) e $70 \mathrm{~g}$ de cloreto de potássio (40 g de $\mathrm{K}_{2} \mathrm{O}$ ). Para a adubação de fósforo, aplicou-se $650 \mathrm{~g} /$ cova de supersimples $\left(117 \mathrm{~g} \mathrm{de} \mathrm{P}_{2} \mathrm{O}_{5}\right) \mathrm{e}$ $250 \mathrm{~g} /$ cova do mesmo adubo (45 $\mathrm{g} \mathrm{P}_{2} \mathrm{O}_{5}$ ). As adubações de cobertura foram realizadas em círculo, à distância de 40 a $50 \mathrm{~cm}$ do colo da planta superficialmente, porém, o superfosfato simples foi incorporado no solo. Entre setembro, outubro, novembro, dezembro de 2012 e janeiro de 2013, foram realizadas aplicações de adubo via fertirrigação da seguinte forma: $62,5 \mathrm{~g} /$ cova de ureia (30 g/cova de nitrogênio), $100 \mathrm{~g} /$ cova de cloreto de potássio branco (60 $\mathrm{g} /$ cova de $\mathrm{K}_{2} \mathrm{O}$ ) e $200 \mathrm{~g} /$ cova de nitrabor (30 g/cova de nitrogênio, $40 \mathrm{~g} /$ cova de cálcio e 0,4 g/cova de boro).

Foi feita adubação foliar com 4-16-16 e micronutrientes a 600 ml em 20 litros de água, totalizando a aplicação de 140 litros/ha de calda, com bomba costal. Para o controle das lagartas Dione juno Juno, Agraulis vanillae vanillae e percevejos, foi realizada uma aplicação de $\operatorname{Decis}^{\mathrm{R}}$ (500 ml/ha) adicionado de $1 \mathrm{~L} /$ ha de óleo mineral Assist ${ }^{\mathrm{R}}$ em janeiro de 2013. E para o controle de ácaro, e também com efeito sobre esses insetos, foi feita uma aplicação de 
$\operatorname{Vexter}^{R}$ (abamectina) a $100 \mathrm{ml} /$ ha com óleo mineral Iharol $^{\mathrm{R}} 1 \mathrm{~L} / \mathrm{ha}$ em julho de 2012 . A lavoura foi conduzida utilizando o sistema de sustentação de espaldeira vertical, com mourões distanciados de seis metros e dois fios de arame liso a dois metros de altura e outro a 1,50 em relação ao solo. As plantas foram conduzidas em haste única, tutoradas por barbante até o arame, deixando para fio de arame duas brotações laterais em sentido contrário uma a outra. As brotações, a partir daí, cresceram livremente, não tendo sido realizadas podas de renovação.

As avaliações foram realizadas semanalmente, totalizando trinta e duas colheitas. As colheitas foram realizadas com a coleta somente dos frutos que se encontravam no chão, ou seja, a partir de sua maturação total. Os frutos colhidos eram colocados em caixas de plástico e separados com identificação. Em seguida as caixas eram levadas a um galpão destinado a avaliação pós-colheita, para a pesagem e classificação. As avaliações de desempenho foram iniciadas em outubro de 2012 e findadas em agosto de 2013. Não se realizou polinização artificial para aumentar a frutificação.

As variáveis analisadas foram: produtividade estimada $(\mathrm{Kg} / \mathrm{ha})$, número total de frutos por hectare, massa média de frutos (g), classificação dos frutos quanto ao diâmetro equatorial em três categorias como mostra a Tabela 22 .

Tabela 22. Classificação dos frutos de acordo com o seu diâmetro equatorial (mm), utilizada no experimento de avaliação de quarenta e oito progênies cultivadas na FAL - UnB, 2012 a 2013.

\begin{tabular}{|c|c|}
\hline CLASSIFICAÇÃO & DIÂMETRO EQUATORIAL (MM) \\
\hline Primeira & Diâmetro maior que 55 \\
\hline 1B & Diâmetro do fruto maior que 55 e menor que 65 \\
\hline 1A & Diâmetro maior que 65 e menor do que 75 \\
\hline
\end{tabular}

Fonte: RANGEL (2002).

Frutos de Primeira e 1B são frutos considerados ideais para a indústria, pois não são aceitos nos mercados in natura devido ao reduzido tamanho. As demais classes $1 \mathrm{~A}$ e $2 \mathrm{~A}$ são destinadas aos mercados comerciais de fruta fresca (COIMBRA, 2010).

Os dados experimentais coletados foram transformados em raiz de $\mathrm{x}+1$, e submetidos à análise de variância e comparados pelo teste de média Tukey a 5\% de probabilidade.

Foram obtidas as estimativas das variâncias genotípica entre os acessos $\left(\widehat{\boldsymbol{\sigma}}_{\boldsymbol{g}}^{\mathbf{2}}\right)$, fenotípica ao nível de média $\left(\widehat{\boldsymbol{\sigma}}_{\boldsymbol{f}}^{\mathbf{2}}\right)$ e ambiental média $\left(\widehat{\boldsymbol{\sigma}}_{\boldsymbol{e}}^{\mathbf{2}}\right)$, herdabilidade ao nível $\left(\boldsymbol{h}^{\mathbf{2}}\right)$, coeficientes de 
variação experimental (CVe) e genético $(\mathrm{CVg})$ para características produtividade total, utilizando-se o programa Genes (CRUZ,1997), em que:

Variância fenotípica entre as médias dos tratamentos: $\hat{\sigma}_{f}^{2}=\frac{Q M g}{r}$

Variância ambiental: $\hat{\sigma}_{e}^{2}=\frac{Q M e}{r}$

Variância genotípica: $\hat{\sigma}_{g}^{2}=\frac{Q M g-Q M e}{r}$

Herdabilidade ao nível de média: $h_{a}^{2}(\%)=\frac{\widehat{\sigma}_{g}^{2}}{\frac{Q M g}{r}} 100$

Coeficiente de variação experimental: $\operatorname{CVe}(\%)=\frac{\sqrt{Q M e}}{\bar{x}} 100$,

onde $\mathrm{x}=$ média do caráter considerado.

Coeficiente de variação genético: $\operatorname{CVg}(\%)=\frac{\sqrt{\widehat{\sigma}_{g}^{2}}}{\bar{x}} 100$

Utilizando-se as estimativas das variâncias e covariâncias fenotípicas, genotípicas e de ambiente, foram determinadas a razão $\mathrm{CVg} / \mathrm{CVe}$ e as correlações fenotípicas com o auxílio do programa GENES (CRUZ, 2007).

\section{3 - RESULTADOS E DISCUSSÃO}

No estudo realizado foi possível observar diferenças estatísticas significativas nas variáveis produtividade total estimada nas quarenta e oito progênies, produtividade de frutos de Primeira, 1B e 1A, número de frutos, número de frutos em cada classificação, massa média total e massa média por classificação de Primeira, 1B e 1 A (Tabela 23) .

No que se refere à produtividade total estimada o número total de frutos, quando relacionados com a classificação do tamanho dos frutos (Primeira, 1B e 1A), das quarenta e oito progênies apresentaram diferenças estatísticas significativas (Tabela 23).

No presente trabalho a que se refere a produtividade total estimada, de quarenta e oito progênies ao longo de trinta e duas colheitas, foi observado que as maiores produtividades totais ocorreram nas progênies MAR20\#2005 Pl.2 (12.261.594 Kg/ha), MAR20\#44 Pl.1 (11.446.119 Kg/ha), MAR20\#24 Pl.2 (10.234.513 Kg/ha), respectivamente, e as menores produtividade foram encontradas em Rosa Claro Pl.3 (1.428.967 Kg/ha) e PA 01 (1.637.696 $\mathrm{Kg} / \mathrm{ha})$.

Em relação à produtividade quanto a classificação de frutos de Primeira as progênies: MAR20\#2005 Pl.2 (6.977.969 Kg/ha), MAR20\#10 (6.489.279Kg/ha) e MAR20\#24 Pl.2 (6.489.279 Kg/ha) apresentaram as maiores produtividades e a progênie PA 01 (918.649 $\mathrm{Kg} / \mathrm{ha}$ ) com menor produtividade. Para frutos de 1B em MAR20\#44 Pl.1 (5.978.565 Kg/ha) e 
MAR20\#2005 Pl.2 (3.906.543 Kg/ha) com maior produtividade dentro dessa classificação e MAR20\#10 (241.279 Kg/ha) com menor produtividade em 1B. Já para frutos de 1A, temos como maior produtividade as progênies MAR20\#46 (1.619.641 Kg/ha), Ribi Gig. Pl.2 (1.499.204 Kg/ha) e MAR20\#2005 Pl.2 (1.377.081 Kg/ha) e com menores valores de produtividade para 1A a progênie MAR20\#21 (0.000Kg/ha).

No que tange à produção de frutos por hectare, os maiores valores foram encontrados nas seguintes progênies: MAR20\#2005 Pl.2, MAR20\#44 Pl.1 e MAR20\#24 P1.2 (107.440 frutos/ha), (98.313 frutos/ha) e (88.035 frutos/ha), respectivamente e a menor produção foi encontrada na progênie Rosa Claro Pl.3 (10.714 frutos/ha).

As progênies estudadas apresentaram diferenças estatísticas significativas na produtividade e número de frutos quando relacionadas com a classificação dos frutos (Primeira, 1B e 1A ). O maior número de frutos de Primeira foi observado na progênie MAR20\#2005 Pl.2 (76.666 frutos/ha), MAR20\#24 P1.2 (66.249 frutos/ha) e MAR20\#34 (65.416 frutos/ha) e o menor em Rosa Claro Pl.3 (8.571 frutos/ha). Para frutos de 1B a maior quantidade de frutos por hectare foi para a progênie MAR20\#44 Pl.1 (49.226 frutos/ha), MAR20\#19 (30.773 frutos/ha) e MAR20\#2005 Pl.2 (25.416 frutos/ha) e para menor quantidade de frutos por hectare de 1B a progênie Rosa Claro P1.2 que apresentou (1.607 frutos/ha). Com relação a frutos de $1 \mathrm{~A}$, as progênies que apresentaram maior quantidade de frutos por hectare foram MAR20\#46 (9.047 frutos/ha) e MAR20\#2005 Pl.2 (5.357 frutos/ha) e a menor quantidade de frutos por hectare foi verificada na progênie MAR20\#21 (0.000 frutos/ha). Sendo assim, podemos dizer que a progênie MAR20\#2005 Pl.2 destacou-se no presente estudo quanto a número de frutos de Primeira, 1B e 1A, assim, produzindo a maior quantidade de número de frutos. Diferentemente, a progênie MAR20\#21 não produziu frutos de $1 \mathrm{~A}$.

Com os resultados obtidos foi possível observar que a progênie MAR20\#2005 P1.2 obteve a maior produtividade total e maior produtividade em frutos classificados como de Primeira, também superou as outras progênies em número de frutos total e número de frutos classificados como de Primeira. Já a progênie MAR20\#44 Pl.1, destacou-se com a melhor produtividade e a melhor quantidade de frutos classificados como 1B e a progênie MSCA foi a que obteve a maior massa média total e maior massa média na classificação de frutos de Primeira.

GONÇALVES, (2011), avaliando a produtividade total estimada em vinte e seis progênies de maracujazeiro-amarelo, observou ao longo de cinquenta e seis colheitas que as 
progênies MAR20\#15 com $32.762 \mathrm{~kg} / \mathrm{ha}$ apresentou a maior produtividade, diferindo estatisticamente da progênie PES9, que apresentou a menor produtividade, com $16.771 \mathrm{~kg} / \mathrm{ha}$.

Em estudos realizados por SOUSA, (2009), no ensaio de campo com quarenta e uma colheitas, obteve para MAR20\#15 maior produtividade estimada de $29.082 \mathrm{~kg} / \mathrm{ha}$ diferindo estatisticamente da progênie PES9 que apresentou menor produtividade, com 14.103kg/ha.

(VILELA, 2013), no que se refere à produção de frutos/ha, em 32 progênies de maracujazeiro-azedo, cultivadas na fazenda Água Limpa, com duração de 28 colheitas, encontrou diferenças estatísticas nas progênies avaliadas. Uma das progênies que se destacou foi a FB 200 com 150.545 frutos/ha e a progênie MAR20\#39 obteve uma das menores quantidades de frutos com 55.226 frutos/ha.

Ainda no que se refere à produtividade total estimada quando comparada com a realizada por outros pesquisadores, vale a pena ressaltar que as progênies pesquisadas por GONÇALVES, (2011); SOUZA, (2009), tiveram comportamento semelhante as progênies MAR20\#15 com maior valor de produtividade e PES9 com menor valor de produtividade.

Quanto à produtividade estimada e o número total de frutos produzidos quando relacionados com a classificação do tamanho dos frutos (Primeira, 1B e 1A), as quarenta e oito progênies apresentaram diferenças estatísticas nas classes pesquisadas (Tabela 23).

Com relação a frutos de Primeira, MOREIRA, (2011) e VILELA, (2013) observaram resultados semelhantes, onde, para frutos de primeira, a maior massa média ocorreu na progênie MAR20\#15. SOUSA (2005) encontrou na progênie FB 200 a maior massa média de frutos com 120.00g/frutos. Com relação a frutos de 1A MAIA (2008) encontrou na progênie AR2 maior massa média de frutos com $227 \mathrm{~g} /$ frutos.

No presente trabalho, as quarenta e oito progênies não apresentaram diferenças estatísticas quando se refere a maior massa média total de frutos. Podemos destacar as progênies MSCA $(154,99 \mathrm{~g} /$ frutos), Rosa Claro Pl.3 (154,98g/frutos) e Rosa Claro Pl.1 (146,28g/frutos) e menor massa média total de frutos em MAR20\#44 Pl.1 (12,09g/frutos). Com relação a frutos de Primeira não houve diferença estatística entre as progênies apresentando os maiores valores as progênies MSCA (141,35g/frutos) e MAR20\#19 $(140,09 \mathrm{~g} /$ frutos) e menores valores para MAR20\#44 (67,40g/frutos). Em frutos de 1B houve diferenças estatísticas tendo como a maior massa média a progênie MAR20\#21 (709,95g/frutos) e menor PA01 (101,95g/frutos). Em frutos de 1A houve diferenças estatísticas, sendo a progênie de maior massa média MAR20\#15 (451,14g/frutos) e menor massa média MAR20\#21 (0,00 g/frutos). 
É relevante mencionar o alto valor de massa média em frutos de 1B para a progênie MAR20\#21e em frutos de 1A a menor massa média podendo ser uma progênie promissora para frutos com características voltadas para a indústria.

Com relação à massa média total e massa média de frutos de Primeira, podemos destacar como promissora progênie a MSCA com características voltadas para a indústria.

É importante considerar a polinização entomófila que normalmente resulta na produção de frutos menores em relação à polinização manual, justificando a maior quantidade de frutos classificados para indústria e não para o comércio in natura como no presente trabalho, por não ter sido realizada polinização artificial. Além disso, é importante dizer que ainda o mercado industrial domina o agronegócio do maracujazeiro-azedo (JUNQUEIRA et. al., 2003).

Tabela 23. Número total de frutos de $1^{\circ}, 1 \mathrm{~B}$ e $1 \mathrm{~A}$ (frutos/ha), produtividade (Kg/ha) e massa média (g/frutos) por classificação de frutos quanto ao diâmetro equatorial.

\begin{tabular}{|c|c|c|c|c|c|c|c|c|c|c|c|c|}
\hline Progênies & NF $1^{\circ}$ & NF 1B & $\begin{array}{l}\text { NF } \\
1 \mathrm{~A}\end{array}$ & $\begin{array}{c}\text { NF } \\
\text { TOTAL } \\
\text { (frutos/ha) }\end{array}$ & PESO $1^{\circ}$ & PESO 1B & PESO 1A & $\begin{array}{c}\text { PESO } \\
\text { TOTAL } \\
\text { (Kg/ha) }\end{array}$ & $\begin{array}{c}\text { PESO } \\
\text { MÉDI } \\
01^{\circ}\end{array}$ & $\begin{array}{c}\text { PESO } \\
\text { MÉDIO } \\
1 B\end{array}$ & $\begin{array}{c}\text { PESO } \\
\text { MÉDI } \\
\text { O 1A }\end{array}$ & $\begin{array}{c}\text { PESO } \\
\text { MÉDI } \\
\text { O } \\
\text { TOTA } \\
\text { L (g) } \\
\end{array}$ \\
\hline $\begin{array}{c}\text { MAR20\#2005 } \\
\text { Pl.1 } \\
\end{array}$ & $35.630 \mathrm{~b}$ & $8.452 \mathrm{a}$ & $3.214 b$ & $50.357 \mathrm{~b}$ & $3.556 .544 b$ & $1.566 .442 \mathrm{a}$ & $732.142 b$ & $5.876 .259 \mathrm{~b}$ & $94,16 a$ & $193,73 a$ & $232,67 b$ & $117,27 \mathrm{a}$ \\
\hline $\begin{array}{c}\text { MAR20\#2005 } \\
\text { Pl.2 } \\
\end{array}$ & $76.666 b$ & $25.416 b$ & $5.357 \mathrm{~b}$ & $107.440 \mathrm{~b}$ & $6.977 .969 b$ & $3.906 .543 b$ & $1.377 .081 \mathrm{c}$ & $12.261 .594 b$ & $91,79 a$ & $149,05 a$ & $257,46 b$ & $113,20 \mathrm{a}$ \\
\hline $\begin{array}{c}\text { MAR20\#2005 } \\
\text { Pl.3 }\end{array}$ & $45.952 b$ & $10.892 \mathrm{a}$ & $535 \mathrm{a}$ & $57.380 \mathrm{~b}$ & $4.036 .305 b$ & $1.894 .640 \mathrm{~b}$ & $136.904 \mathrm{a}$ & $6.067 .850 \mathrm{~b}$ & $97,40 \mathrm{a}$ & $217,97 a$ & $63,89 a$ & $116,95 \mathrm{a}$ \\
\hline $\begin{array}{c}\text { MAR20\#2005 } \\
\text { Pl.4 }\end{array}$ & $52.860 \mathrm{~b}$ & $8.174 a$ & $1.607 \mathrm{~b}$ & $62.701 b$ & 4.017.555b & $1.919 .045 b$ & $523.213 b$ & $6.502 .672 b$ & $81,42 \mathrm{a}$ & $231,62 \mathrm{a}$ & $304,64 b$ & $104,58 \mathrm{a}$ \\
\hline 20\#34 F2 & $16.964 a$ & $2.797 \mathrm{a}$ & $2.738 \mathrm{~b}$ & $22.857 \mathrm{a}$ & $1.577 .776 \mathrm{a}$ & $747.618 \mathrm{a}$ & $517.936 \mathrm{~b}$ & $2.943 .033 \mathrm{a}$ & $92,92 \mathrm{a}$ & $242,05 \mathrm{a}$ & $215,04 b$ & $140,64 \mathrm{a}$ \\
\hline AP 01 & $47.460 \mathrm{~b}$ & $14.285 \mathrm{~b}$ & $1.825 \mathrm{~b}$ & $63.571 \mathrm{~b}$ & $4.119 .043 b$ & $2.194 .045 b$ & $530.961 b$ & $6.844 .040 \mathrm{~b}$ & $88,57 \mathrm{a}$ & $159,25 a$ & $283,67 b$ & $110,04 \mathrm{a}$ \\
\hline AR 2 & $36.845 b$ & $14.583 b$ & $1.071 \mathrm{a}$ & $52.499 \mathrm{~b}$ & $3.261 .306 \mathrm{~b}$ & $2.026 .783 b$ & $297.916 \mathrm{a}$ & $5.586 .006 \mathrm{~b}$ & $89,73 a$ & $170,31 \mathrm{a}$ & $263,95 b$ & $112,5 \mathrm{a}$ \\
\hline
\end{tabular}




\begin{tabular}{|c|c|c|c|c|c|c|c|c|c|c|c|c|}
\hline Progênies & NF $1^{\circ}$ & NF $1 B$ & $\begin{array}{l}\text { NF } \\
\mathbf{1 A}\end{array}$ & $\begin{array}{c}\text { NF } \\
\text { TOTAL } \\
\text { (frutos/ha) }\end{array}$ & PESO $1^{\circ}$ & PESO 1B & PESO 1A & $\begin{array}{c}\text { PESO } \\
\text { TOTAL } \\
\text { (Kg/ha) }\end{array}$ & $\begin{array}{c}\text { PESO } \\
\text { MÉDI } \\
\text { O 1 }^{\circ}\end{array}$ & $\begin{array}{c}\text { PESO } \\
\text { MÉDIO } \\
1 B\end{array}$ & $\begin{array}{c}\text { PESO } \\
\text { MÉDI } \\
\text { O 1A }\end{array}$ & $\begin{array}{c}\text { PESO } \\
\text { MÉDI } \\
\text { O } \\
\text { TOTA } \\
\text { L (g) }\end{array}$ \\
\hline EC3-0 & $32.857 \mathrm{a}$ & $7.440 \mathrm{a}$ & $1.428 \mathrm{~b}$ & $41.785 a$ & $3.130 .354 a$ & $1.252 .974 \mathrm{a}$ & $390.475 b$ & $4.792 .257 \mathrm{a}$ & $95,62 \mathrm{a}$ & $179,39 a$ & $267,70 \mathrm{~b}$ & $122,34 a$ \\
\hline EC3-0 Pl.1 & $13.215 \mathrm{a}$ & $13.095 \mathrm{a}$ & $1.547 \mathrm{~b}$ & $27.858 \mathrm{a}$ & $1.192 .260 \mathrm{a}$ & $617.558 \mathrm{a}$ & $416.071 b$ & $2.225 .890 \mathrm{a}$ & $96,60 \mathrm{a}$ & $165,77 \mathrm{a}$ & $257,85 b$ & $114,34 \mathrm{a}$ \\
\hline ECL 7 & $38.928 b$ & $7.976 \mathrm{a}$ & $1.904 \mathrm{~b}$ & $48.928 b$ & $3.331 .841 \mathrm{~b}$ & $1.422 .915 \mathrm{a}$ & $402.380 \mathrm{~b}$ & $5.204 .459 \mathrm{~b}$ & $92,81 \mathrm{a}$ & $202,24 a$ & $211,76 b$ & $120,60 a$ \\
\hline ECRAM PI.2 & $26.666 a$ & $16.984 b$ & $4.047 \mathrm{~b}$ & $47.698 \mathrm{a}$ & $2.730 .056 \mathrm{a}$ & $2.321 .029 \mathrm{~b}$ & $881.546 b$ & $5.932 .632 \mathrm{~b}$ & $104,88 \mathrm{a}$ & $150,30 \mathrm{a}$ & $240,15 b$ & $115,09 a$ \\
\hline ECRAM PI.3 & $34.166 b$ & $5.773 a$ & $1.031 \mathrm{a}$ & $40.972 a$ & $3.472 .317 \mathrm{~b}$ & $998.213 \mathrm{a}$ & $288.094 a$ & $4.758 .626 \mathrm{a}$ & $92,72 \mathrm{a}$ & $168,52 \mathrm{a}$ & $264,79 b$ & $110,21 \mathrm{a}$ \\
\hline FB 200 & $46.785 b$ & $7.619 \mathrm{a}$ & $1.071 \mathrm{a}$ & $55.476 \mathrm{~b}$ & $4.382 .138 \mathrm{~b}$ & $1.349 .403 \mathrm{a}$ & $286.011 \mathrm{a}$ & $6.014 .553 \mathrm{~b}$ & $99,25 \mathrm{a}$ & $179,91 \mathrm{a}$ & $260,94 b$ & $113,57 \mathrm{a}$ \\
\hline GAZ PI.1 & $36.845 b$ & $17.916 \mathrm{~b}$ & $4.285 b$ & $59.047 b$ & $3.339 .282 \mathrm{a}$ & $2.554 .461 \mathrm{~b}$ & $1.117 .856 \mathrm{~b}$ & $7.011 .600 \mathrm{~b}$ & $80,66 a$ & $155,38 \mathrm{a}$ & $259,20 b$ & $97,98 \mathrm{a}$ \\
\hline $\begin{array}{c}\text { Gig. Amar } \\
\text { Pl.1 }\end{array}$ & $26.904 a$ & $5.535 \mathrm{a}$ & $476 a$ & $32.916 \mathrm{a}$ & $2.430 .647 \mathrm{a}$ & $1.042 .260 \mathrm{a}$ & $122.023 \mathrm{a}$ & $3.594 .932 \mathrm{a}$ & $88,47 \mathrm{a}$ & $178,02 \mathrm{a}$ & $251,93 b$ & $113,89 a$ \\
\hline $\begin{array}{c}\text { Gig. Amar } \\
\text { Pl.2 }\end{array}$ & $35.059 \mathrm{~b}$ & $6.369 a$ & $1.369 \mathrm{~b}$ & $42.797 b$ & 2.678.092a & $1.105 .356 \mathrm{a}$ & $426.190 \mathrm{~b}$ & 4.209.638a & $81,82 \mathrm{a}$ & $171,69 a$ & $304,56 b$ & $118,33 a$ \\
\hline $\begin{array}{c}\text { Gig. Amar } \\
\text { Pl.3 }\end{array}$ & $20.952 \mathrm{a}$ & $6.964 \mathrm{a}$ & $3.015 b$ & $31.170 \mathrm{a}$ & $1.865 .771 \mathrm{a}$ & 1.024.106a & $496.031 b$ & $3.447 .814 \mathrm{a}$ & $97,44 a$ & $170,30 \mathrm{a}$ & $206,67 b$ & $122,84 a$ \\
\hline MAR20\#10 & $61.368 b$ & $18.273 b$ & $3.690 \mathrm{~b}$ & $83.333 b$ & $6.489 .279 b$ & $241.279 b$ & $637.511 b$ & $3.808 .904 b$ & $92,26 a$ & $141,27 \mathrm{a}$ & $204,76 b$ & $114,81 \mathrm{a}$ \\
\hline $\begin{array}{l}\text { MAR20\#12 } \\
\text { Pl. } 2 \\
\end{array}$ & $28.160 \mathrm{a}$ & $8.392 \mathrm{a}$ & $2.559 \mathrm{~b}$ & $39.339 a$ & $2.419 .045 \mathrm{a}$ & $1.498 .510 \mathrm{a}$ & $372.023 b$ & $4.429 .162 \mathrm{a}$ & $89,75 a$ & $200,71 a$ & $257,39 b$ & $121,18 \mathrm{a}$ \\
\hline MAR20\#15 & $27.619 a$ & $7.916 \mathrm{a}$ & $2.142 b$ & $37.678 \mathrm{a}$ & $2.208 .926 \mathrm{a}$ & $1.146 .129 \mathrm{a}$ & $690.475 b$ & $4.045 .531 \mathrm{a}$ & $88,19 a$ & $161,10 \mathrm{a}$ & $451,14 b$ & $110,17 \mathrm{a}$ \\
\hline MAR20\#19 & $35.238 \mathrm{~b}$ & $30.773 b$ & $5.159 \mathrm{~b}$ & $71.408 b$ & $4.786 .007 \mathrm{~b}$ & $3.463 .687 \mathrm{~b}$ & $1.155 .356 \mathrm{c}$ & $9.451 .776 \mathrm{~b}$ & $140,09 a$ & $141,79 a$ & $312,63 b$ & $128,01 \mathrm{a}$ \\
\hline $\begin{array}{c}\text { MAR20\#24 } \\
\text { Pl.1 } \\
\end{array}$ & $39.285 b$ & $14.999 \mathrm{a}$ & $2.619 \mathrm{~b}$ & $56.964 b$ & $3.040 .175 \mathrm{a}$ & $1.231 .844 \mathrm{a}$ & $390.475 b$ & 4.689.281a & $77,61 \mathrm{a}$ & $208,90 a$ & $187,92 b$ & $89,01 \mathrm{a}$ \\
\hline $\begin{array}{c}\text { MAR20\#24 } \\
\text { Pl.2 }\end{array}$ & $66.249 b$ & $19.761 b$ & $1.964 b$ & $88.035 b$ & $6.489 .279 b$ & $3.199 .401 b$ & $530.356 b$ & $10.234 .513 b$ & $93,22 \mathrm{a}$ & $161,13 a$ & $268,48 b$ & $127,62 \mathrm{a}$ \\
\hline MAR20\#34 & $65.416 b$ & $15.952 b$ & $2.778 b$ & $84.147 b$ & $5.340 .470 \mathrm{~b}$ & $2.695 .533 \mathrm{~b}$ & $805.157 b$ & $8.841 .161 \mathrm{~b}$ & $92,05 \mathrm{a}$ & $175,08 \mathrm{a}$ & $302,61 b$ & $111,63 a$ \\
\hline MAR20\#39 & $44.702 b$ & $9.345 \mathrm{a}$ & $2.301 \mathrm{~b}$ & $56.349 \mathrm{~b}$ & $4.743 .150 \mathrm{~b}$ & $1.833 .033 b$ & $464.582 b$ & $7.040 .766 \mathrm{~b}$ & $106,03 a$ & $205,04 a$ & $210,10 b$ & $129,72 \mathrm{a}$ \\
\hline MAR20\#41 & $54.702 \mathrm{~b}$ & $9.642 \mathrm{a}$ & $1.607 \mathrm{~b}$ & $66.190 \mathrm{~b}$ & $5.094 .637 \mathrm{~b}$ & $1.900 .890 \mathrm{~b}$ & $435.118 b$ & $7.499 .397 b$ & $98,94 \mathrm{a}$ & $207,77 a$ & $282,69 b$ & $120,36 a$ \\
\hline
\end{tabular}




\begin{tabular}{|c|c|c|c|c|c|c|c|c|c|c|c|c|}
\hline Progênies & NF $1^{\circ}$ & NF $1 B$ & $\begin{array}{l}\text { NF } \\
\mathbf{1 A}\end{array}$ & $\begin{array}{c}\text { NF } \\
\text { TOTAL } \\
\text { (frutos/ha) }\end{array}$ & PESO $1^{\circ}$ & PESO 1B & PESO 1A & $\begin{array}{c}\text { PESO } \\
\text { TOTAL } \\
\text { (Kg/ha) }\end{array}$ & $\begin{array}{c}\text { PESO } \\
\text { MÉDI } \\
\text { O 1 }^{\circ}\end{array}$ & $\begin{array}{c}\text { PESO } \\
\text { MÉDIO } \\
\text { 1B }\end{array}$ & $\begin{array}{c}\text { PESO } \\
\text { MÉDI } \\
\text { O 1A }\end{array}$ & $\begin{array}{c}\text { PESO } \\
\text { MÉDI } \\
\text { O } \\
\text { TOTA } \\
\text { L (g) }\end{array}$ \\
\hline MAR20\#44 & $48.333 b$ & $15.595 b$ & $3.452 b$ & $67.559 b$ & $3.361 .658 \mathrm{a}$ & $2.406 .545 b$ & $656.546 \mathrm{~b}$ & $6.483 .977 \mathrm{~b}$ & $67,40 \mathrm{a}$ & $158,02 \mathrm{a}$ & $239,34 b$ & $108,56 \mathrm{a}$ \\
\hline $\begin{array}{l}\text { MAR20\#44 } \\
\text { PI.1 }\end{array}$ & $44.047 b$ & $49.226 b$ & $4.682 b$ & $98.313 b$ & $4.274 .698 b$ & $5.978 .565 b$ & $1.066 .665 \mathrm{c}$ & $11.446 .119 b$ & $93,30 \mathrm{a}$ & $143,94 a$ & $226,92 b$ & $12,09 \mathrm{a}$ \\
\hline MAR20\#46 & $27.142 \mathrm{a}$ & $10.427 \mathrm{a}$ & $9.047 \mathrm{~b}$ & $46.737 b$ & $2.339 .283 \mathrm{a}$ & $1.334 .224 \mathrm{a}$ & $1.619 .641 \mathrm{c}$ & $5.331 .244 \mathrm{~b}$ & $82,20 \mathrm{a}$ & $143,25 \mathrm{a}$ & $272,22 b$ & $124,83 a$ \\
\hline $\begin{array}{c}\text { MAR20\#46 } \\
\text { Pl.1 }\end{array}$ & $32.142 \mathrm{a}$ & $5.833 \mathrm{a}$ & $1.984 b$ & $39.960 \mathrm{a}$ & 2.244.343a & $908.034 \mathrm{a}$ & $336.904 a$ & $3.489 .282 \mathrm{a}$ & $69,51 \mathrm{a}$ & $162,59 a$ & $175,74 b$ & $95,08 \mathrm{a}$ \\
\hline $\begin{array}{l}\text { MAR20\#46 } \\
\text { PI.2 }\end{array}$ & $46.666 b$ & $9.920 \mathrm{a}$ & $2.065 \mathrm{~b}$ & $59.069 b$ & $3.955 .948 b$ & $1.692 .458 \mathrm{~b}$ & $564.285 b$ & $6.494 .834 b$ & $84,28 \mathrm{a}$ & $171,95 \mathrm{a}$ & $286,79 b$ & $90,69 \mathrm{a}$ \\
\hline MSCA & $37.849 b$ & $8.392 \mathrm{a}$ & $238 a$ & $46.480 \mathrm{~b}$ & $3.924 .400 \mathrm{~b}$ & $1.699 .700 \mathrm{~b}$ & $88.095 \mathrm{a}$ & $5.712 .196 \mathrm{~b}$ & $141,35 a$ & $215,91 \mathrm{a}$ & $92,50 \mathrm{a}$ & $154,99 a$ \\
\hline MSCA PI.1 & $51.130 \mathrm{~b}$ & $18.928 b$ & $3.035 \mathrm{~b}$ & $73.333 b$ & $4.419 .935 b$ & $2.765 .473 b$ & $778.868 b$ & $7.964 .349 \mathrm{~b}$ & $88,76 \mathrm{a}$ & $146,13 a$ & $256,49 b$ & $111,47 \mathrm{a}$ \\
\hline MSCA PI.2 & $58.988 b$ & $16.845 b$ & $1.904 \mathrm{~b}$ & $77.857 \mathrm{~b}$ & $5.182 .435 b$ & $1.502 .677 \mathrm{a}$ & $578.273 b$ & $7.311 .599 \mathrm{~b}$ & $88,63 \mathrm{a}$ & $133,56 a$ & $296,73 b$ & $94,35 \mathrm{a}$ \\
\hline PA 01 & $17.738 \mathrm{a}$ & $7.202 \mathrm{a}$ & $1.349 \mathrm{a}$ & $26.289 a$ & $918.649 \mathrm{a}$ & $555.951 \mathrm{a}$ & $163.095 \mathrm{a}$ & $1.637 .696 \mathrm{a}$ & $111,77 \mathrm{a}$ & $101,95 \mathrm{a}$ & $178,18 b$ & $108,95 \mathrm{a}$ \\
\hline RC 3 & $20.654 a$ & $5.297 \mathrm{a}$ & $2.261 \mathrm{~b}$ & $28.214 a$ & $2.163 .093 \mathrm{a}$ & $844.344 a$ & $568.749 b$ & $3.626 .186 \mathrm{a}$ & $117,48 \mathrm{a}$ & $208,97 a$ & $338,37 b$ & $138,46 a$ \\
\hline $\begin{array}{c}\text { Rosa Claro } \\
\text { Pl.1 }\end{array}$ & $13.273 a$ & $5.238 \mathrm{a}$ & $1.785 b$ & $20.297 \mathrm{a}$ & $1.511 .010 \mathrm{a}$ & $824.106 a$ & $227.083 a$ & $2562199 a$ & $126,10 \mathrm{a}$ & $252,24 a$ & $126,25 a$ & $146,28 \mathrm{a}$ \\
\hline Rosa Int Pl.1 & $58.095 b$ & $14.404 b$ & $3.511 \mathrm{~b}$ & $76.011 \mathrm{~b}$ & $4.886 .304 b$ & $2.554 .461 \mathrm{~b}$ & $426.071 \mathrm{~b}$ & $7.866 .837 \mathrm{~b}$ & $85,05 a$ & $180,10 \mathrm{a}$ & $208,82 b$ & $107,94 a$ \\
\hline Rosa Int PI.2 & $53.690 \mathrm{~b}$ & $15.238 b$ & $2.460 \mathrm{~b}$ & $71.508 \mathrm{~b}$ & $4.037 .198 \mathrm{~b}$ & $2.645 .533 b$ & $494.523 b$ & $7.177 .254 b$ & $84,44 a$ & $156,73 a$ & $199,29 b$ & $103,37 \mathrm{a}$ \\
\hline Rosa Int Pl.3 & $13.215 \mathrm{a}$ & $13.096 \mathrm{a}$ & $773 b$ & $27.085 a$ & $1.192 .260 \mathrm{a}$ & $1.212 .796 \mathrm{a}$ & $207.440 \mathrm{a}$ & $2.612 .497 \mathrm{a}$ & $96,60 \mathrm{a}$ & $178,19 a$ & $123,18 \mathrm{a}$ & $116,43 a$ \\
\hline $\begin{array}{c}\text { Rubi Gig. } \\
\text { Pl.1 }\end{array}$ & $43.035 b$ & $9.821 \mathrm{a}$ & $3.571 \mathrm{~b}$ & $56.726 b$ & $3.919 .043 b$ & $1.847 .022 b$ & $953.570 \mathrm{~b}$ & $6.867 .076 \mathrm{~b}$ & $93,15 \mathrm{a}$ & $188,37 \mathrm{a}$ & $254,14 b$ & $120,27 a$ \\
\hline $\begin{array}{c}\text { Rubi Gig. } \\
\text { Pl.2 }\end{array}$ & $56.666 b$ & $16.369 b$ & $3.253 b$ & $76.349 b$ & $4.627 .971 b$ & $2.836 .604 \mathrm{~b}$ & $1.499 .204 \mathrm{c}$ & $8.984 .911 b$ & $80,67 \mathrm{a}$ & $168,97 a$ & $124,63 b$ & $107,47 a$ \\
\hline $\begin{array}{c}\text { Rosa Claro } \\
\text { Pl.3 }\end{array}$ & $8.571 \mathrm{a}$ & $2.023 \mathrm{a}$ & $119 a$ & $10.714 a$ & $949.205 a$ & $409.523 a$ & $70.238 \mathrm{a}$ & $1.428 .967 \mathrm{a}$ & $126,17 \mathrm{a}$ & $230,94 a$ & $147,50 \mathrm{a}$ & $154,98 \mathrm{a}$ \\
\hline MAR20\#21 & $14.888 \mathrm{a}$ & $2.964 a$ & $0.000 \mathrm{a}$ & $17.845 \mathrm{a}$ & $1.646 .426 \mathrm{a}$ & $660.118 \mathrm{a}$ & $0.000 \mathrm{a}$ & $2.306 .545 \mathrm{a}$ & $103,13 a$ & $709,95 b$ & $000,00 \mathrm{a}$ & $121,27 \mathrm{a}$ \\
\hline Rosa Claro & $16.011 \mathrm{a}$ & $1.607 \mathrm{a}$ & $714 \mathrm{a}$ & $18.333 \mathrm{a}$ & $1.456 .646 \mathrm{a}$ & $318.452 \mathrm{a}$ & $199.206 \mathrm{a}$ & $1.974 .204 \mathrm{a}$ & $104,96 a$ & $205,21 \mathrm{a}$ & $278,92 b$ & $127,99 a$ \\
\hline
\end{tabular}




\begin{tabular}{|c|c|c|c|c|c|c|c|c|c|c|c|c|}
\hline Progênies & NF $1^{\circ}$ & NF $1 B$ & $\begin{array}{l}\text { NF } \\
\text { 1A }\end{array}$ & $\begin{array}{c}\text { NF } \\
\text { TOTAL } \\
\text { (frutos/ha) }\end{array}$ & PESO $1^{\circ}$ & PESO 1B & PESO 1A & $\begin{array}{c}\text { PESO } \\
\text { TOTAL } \\
\text { (Kg/ha) }\end{array}$ & $\begin{array}{c}\text { PESO } \\
\text { MÉDI } \\
\text { O 1 }^{\circ}\end{array}$ & $\begin{array}{c}\text { PESO } \\
\text { MÉDIO } \\
1 B\end{array}$ & $\begin{array}{c}\text { PESO } \\
\text { MÉDI } \\
\text { O 1A }\end{array}$ & $\begin{array}{c}\text { PESO } \\
\text { MÉDI } \\
\text { O } \\
\text { TOTA } \\
\text { L (g) }\end{array}$ \\
\hline \multicolumn{13}{|l|}{ Pl.2 } \\
\hline PES 9 & $17.539 a$ & $2.222 \mathrm{a}$ & $294 a$ & $20.119 a$ & $1.361 .109 \mathrm{a}$ & $456.745 a$ & $84.845 \mathrm{a}$ & $1.921 .129 \mathrm{a}$ & $78,41 \mathrm{a}$ & $219,70 \mathrm{a}$ & $68,75 \mathrm{a}$ & $93,84 a$ \\
\hline $\begin{array}{c}\text { MAR20\#12 } \\
\text { PI.1 }\end{array}$ & $19.404 \mathrm{a}$ & $9.842 \mathrm{a}$ & $2.023 b$ & $31.271 \mathrm{a}$ & $1.918 .450 \mathrm{a}$ & $1.609 .132 \mathrm{a}$ & $494.285 b$ & $4.021 .867 \mathrm{a}$ & $106,12 \mathrm{a}$ & $188,25 \mathrm{a}$ & $272,22 b$ & $124,83 \mathrm{a}$ \\
\hline $\begin{array}{c}\text { MAR20\#34 } \\
\text { PI.7 } \\
\end{array}$ & $42.142 b$ & $15.238 b$ & $1.666 \mathrm{~b}$ & $59.258 b$ & $3.536 .157 b$ & $2.212 .101 \mathrm{~b}$ & $465.872 b$ & $6.349 .845 b$ & $84,38 \mathrm{a}$ & $148,40 \mathrm{a}$ & $283,07 \mathrm{~b}$ & $107,52 \mathrm{a}$ \\
\hline
\end{tabular}

*Médias seguidas pela mesma letra não diferem entre si estatisticamente pelo teste de Scott Knott ao nível de 5\%. 
As estimativas de parâmetros genéticos para as variáveis respostas número de frutos de Primeira, número de frutos de $1 \mathrm{~B}$, número de frutos de $1 \mathrm{~A}$, número de frutos total, produtividade de Primeira, produtividade de 1B, produtividade de 1A, produtividade total, peso médio de Primeira, peso médio de 1B, peso médio de 1A, peso médio total podem ser observadas na Tabela 24 .

VILELA, (2013), em seu trabalho verificou razão CVg/Cve para produtividade total estimada de 0,64, abaixo de 1 , o que reflete uma condição desfavorável à seleção, uma vez que a variância genética foi menor que a variância ambiental. Da mesma forma ocorreu no presente trabalho, pois a razão $\mathrm{CVg} / \mathrm{Cve}$ para produtividade total estimada apresentou resultado de 0,47. Sendo assim, segundo (ALVES, 2004), valores dessa magnitude indicam que o emprego de métodos simples de melhoramento (ex: seleção massal) não proporcionarão ganhos expressivos durante o processo de seleção. O emprego de métodos de melhoramento baseados no desempenho de famílias é mais adequado do que aqueles que utilizam a seleção com base na performance de plantas individuais.

Foi possível verificar que a produtividade de frutos de Primeira apresentou baixa herdabilidade $(24,72 \%)$, assim como a razão $\mathrm{CVg} / \mathrm{Cve}(0,28)$, desfavorecendo a seleção, nesse caso. Diferentemente o peso médio de frutos de $1 \mathrm{~A}$ apresentou alta herdabilidade de 75,27\% e razão CVg/Cve 0,87 para essa variável resposta, indicando condição favorável de seleção, uma vez que a variância genética supera a ambiental (VENCOVSKY, 1987), levando a acreditar na existência de grande variabilidade genética para esse caráter e que métodos simples, como o de seleção massal, poderiam proporcionar ganhos significativos nos programas de melhoramento genético do maracujazeiro.

Em trabalho com vinte e seis progênies (VILELA, 2013), encontrou, para número de frutos e massa média total, os valores de herdabilidade e razão $\mathrm{CVg} / \mathrm{CVe}$, que foram de $55 \%$ e $0,53,22 \%$ e 0,26 , respectivamente, e quanto às classes, o número total de frutos e a produtividade total apresentaram os seguintes valores de herdabilidade, nessa ordem: frutos de primeira $(79 \%$ e $79 \%)$, 1B $(54 \%$ e $62 \%)$ e $1 \mathrm{~A}(12 \%$ e $57 \%)$. Outros resultados foram apresentados por (MOREIRA, 2011), com herdabilidade de $65 \%$ e valor $\mathrm{CVg} / \mathrm{CVe}$ de 0,69 para produtividade total estimada, com 32 progênies e vinte colheitas. GONÇALVES, (2011), trabalhando com vinte e seis pregênies de maracujazeiro-amarelo, em cinquenta e seis colheitas, obteve valores de herdabilidade e razão $\mathrm{CVg} / \mathrm{CV}$ e para produtividade total estimada de $39 \%$ e 0.39 , respectivamente. 
Tabela 24. Estimativas de herdabilidade sentido amplo $\left(\mathrm{ha}^{2}\right)$, coeficiente de variação genético $(\mathrm{CVg})$ e razão entre coeficiente e variação genética e ambiental $(\mathrm{CVg} / \mathrm{CVe})$, utilizando-se dados de trinta e duas colheitas de quarenta e oito progênies de maracujazeiroazedo em campo no Distrito Federal, descritos para doze variáveis resposta. Brasília, 2012/2013.

\begin{tabular}{|c|c|c|c|c|c|c|}
\hline $\begin{array}{c}\text { Parâmetros } \\
\text { Genéticos }\end{array}$ & NF 1a & NF 1B & NF 1A & NFT & P 1 & P 1B \\
\hline $\begin{array}{c}\text { ha }^{2} \text { (média } \\
\text { família) }\end{array}$ & $68,07 \%$ & $58,72 \%$ & $44,92 \%$ & $66,39 \%$ & $24,72 \%$ & $55,64 \%$ \\
\hline Cvg & $6,46 \%$ & $20,15 \%$ & $22,44 \%$ & $34,25 \%$ & $52,13 \%$ & $19,08 \%$ \\
\hline CVg/CVe & 0,73 & 0,60 & 0,45 & 0,70 & 0,28 & 0,56 \\
\hline $\begin{array}{c}\text { Parâmetros } \\
\text { Genéticos }\end{array}$ & P1A & PT & PM1 & PM1B & PM1A & PMT \\
\hline $\begin{array}{c}\text { ha' (média } \\
\text { família) }\end{array}$ & $55,62 \%$ & $47,38 \%$ & $68,75 \%$ & $59,04 \%$ & $75,27 \%$ & $54,56 \%$ \\
\hline Cvg & $19,41 \%$ & $20,64 \%$ & $34,55 \%$ & $19,59 \%$ & $23,77 \%$ & $84,41 \%$ \\
\hline CVg/CVe & 0,56 & 0,47 & 0,74 & 0,60 & 0,87 & 0,55 \\
\hline
\end{tabular}

* Médias na coluna seguidas pelas mesmas letras não diferem estatisticamente entre si pelo teste de Scott Knott ao nível de 5\%.

$\mathrm{NF}^{\mathrm{a}}$ : número de frutos de Primeira, NF 1B: número de frutos de 1B, NF 1A: número de frutos de 1A, NFT: número de frutos total (frutos/ha), $\mathrm{P} 1^{\mathrm{a}}$ : produtividade de primeira, $\mathrm{P} 1 \mathrm{~B}$ : produtividade de 1B, P1 A: produtividade de $1 \mathrm{~A}, \mathrm{PT}$ : produtividade total $(\mathrm{Kg} / \mathrm{ha}), \mathrm{PM}^{\mathrm{a}}$ : peso médio de primeira, PM 1B: peso médio de 1B, PM 1 A: peso médio de $1^{\mathrm{a}}$ e PMT: peso médio total (g/frutos). 


\section{4 - CONCLUSÕES}

A progênie MAR20\#2005 Pl.2 obteve a maior produtividade total e a maior produtividade em frutos classificados como de Primeira, também superou as outras progênies em número de frutos total e número de frutos classificados como de Primeira.

A progênie MAR20\#44 Pl.1 destacou-se com a melhor produtividade e a melhor quantidade de frutos classificados como 1B e a progênie MSCA foi a que obteve a maior massa média total e maior massa média na classificação de frutos de Primeira.

Já a progênie MAR20\#21 obteve alta massa média para frutos classificados como de 1B, no entanto, para frutos de 1A nenhum fruto foi produzido e a progênie MAR20\#15 obteve a maior massa média para frutos classificados como 1A.

As progênies destacadas estão inseridas no potencial para a seleção de futuros cruzamentos, visando ao aumento da produtividade e qualidade.

O menor valor de herdabilidade e razão $\mathrm{CVg} / \mathrm{Cve}$ foi encontrado para a variável Produtividade de frutos de Primeira e maiores valores para peso médio de frutos de $1 \mathrm{~A}$ $(24,72 \% ; 0,28)$ e $(75,27 \% ; 0,87)$, respectivamente. Para o segundo caso, a variância genética supera a ambiental, levando a crer na existência de grande variabilidade genética para esse caráter. 


\section{REFERÊNCIAS BIBLIOGRÁFICAS}

ALVES, J. C. S. Estimativa de parâmetros genéticos para caracteres de semente e de planta em populações de cenoura (Daucus carota L.) derivadas da cultivar Brasília. Brasília, DF: Universidade de Brasília, 2004. p.68. Dissertação (Mestrado em Ciências Agrárias).

Banco de dados agregados do sistema do Instituto Brasileiro de Geografia e Estatística de Recuperação Automática

SIDRA. http://www.sidra.ibge.gov.br/bda/tabela/protabl.asp?z=p\&o=22\&i=P. Acesso em: dezembro de 2012.

COIMBRA, K. G. Desempenho agronômico de progênies de maracujazeiro azedo no

Distrito Federal. . Brasília: Faculdade de Agronomia e Medicina Veterinária, Universidade de Brasília,2010. p. 125. Dissertação de Mestrado.

CRUZ, C. D. Programa Genes: aplicativo computacional em genética e estatística. Viçosa: Editora UFV,1997. p. 442.

DURIGAN, J.F.; SIGRIST, J.M.M.; ALVES, R.E.; FILQUEIRAS, H.A.C.; VIERIA, G. Qualidade e tecnologia pós-colheita do maracujá. In: Maracujá: produção e qualidade na passicultura. Editores técnicos: Adelise de Almeida Lima, Mario Augusto Pinto da Cunha. Cruz das Almas: Embrapa Mandioca e Fruticultura, 2004. p. 239-280.

FALEIRO, F. G.; JUNQUEIRA, N. T. V.; FÁVERO, A. P.; LOPES, M. A. Prémelhoramento de plantas: experiências de sucesso. In: FALEIRO, F. G.; NETO, A. L. F.; JÚNIOR, W. Q. R. Pré-melhoramento, melhoramento e pós-melhoramento: estratégias e desafios. Planaltina, DF: Embrapa Cerrados, Embrapa Informação Tecnológica, 2008.

JUNQUEIRA, N.T.V. \& BRAGA, M.F. Maracujá: germoplasma e melhoramento genético. In: FALEIRO, F.G., JUNQUEIRA, N.T.V. \& BRAGA, M.F. (Eds.). Germoplasma e melhoramento genético do maracujazeiro - desafios da pesquisa. Planaltina, DF: Embrapa Cerrados, 2005a. p.187-210.

FOLEGATTI, M.I.S. \& MATSUURA, F.C.A.U. Produtos. Maracujá: pós-colheita. Brasília: Embrapa Informação Tecnológica, 2001. p.51. (Frutas do Brasil, 23). 
GONÇALVES, I.M.P. Produtividade e reação de progênies de maracujazeiro azedo a doenças em campo e casa de vegetação. Brasília: Faculdade de Agronomia e Medicina Veterinária, Universidade de Brasília, 2011. p.121. Dissertação de Mestrado.

GUERRA, N. B; LIVERA, A. V. S. Correlação entre o perfil sensorial e determinações físicas e químicas do abacaxi cv. Pérola. Cruz das Almas. Revista Brasileira de Fruticulura. v. 21, n.1, p. 32-35. abril. 1999.

IBGE - INSTITUTO BRASILEIRO DE GEOGRARIA E ESTATÍSTICA. Maracujá: área plantada e quantidade produzida. Produção Agrícola Municipal em 2009.2011. Disponível em: http://www.sidra.ibge.gov.br/bda/tabela/protabl. Acesso em: fevereiro de 2013.

ITI Tropicals. Disponível em: www.passionfritjuice.com. Acesso em fevereiro de 2012.

JUNQUEIRA, N.T.V.; ANJOS, J. R. N.; SILVA, A. P. O.; CHAVES, R. C.; GOMES, A. C. Reação às doenças e produtividade de onze cultivares de maracujá-azedo cultivadas sem agrotóxicos. Pesquisa Agropecuária Brasileira, 2003. v.38, n.8 p. 1005-1010.

ANJOS, J.R.N.; SHARMA, R.D.; SANZONWICZ, C.; ANDRADE, L.R.M. Doenças do Maracujazeiro. In: Encontro de Fitopatologia, 3. Viçosa, MG: Doenças de fruteiras tropicais - palestras. Viçosa: UFV, 1999. p. 83-115.

LIMA, A.A.; CARDOSO, C.E.L; SOUZA, J.L.; PIRES, M.M. Comercialização do maracujá. Maracujá em foco, número 29. Embrapa - mandioca e fruticultura tropical. 2006.

BORGES, A.L. Clima e solo. In: Lima, A.A. (Ed) Frutas do Brasil - Maracujá produção e aspectos técnicos. Brasília: Embrapa Informação Tecnológica, 2002. p.104.

MAIA, T. E. G. Desempenho agronômico e reação à verrugose e à virose do endurecimento dos frutos de progênies de maracujazeiro-azedo cultivados no Distrito Federal. Brasília: Faculdade de Agronomia e Medicina Veterinária, Universidade de Brasília, 2008. p.121. Dissertação (Mestrado em Ciências Agrárias).

MELO, K. T. Comportamento de seis cultivares de maracujazeiro azedo (Passiflora edulis Sims e Passiflora edulis Sims f. flavicarpa Deg.) em Vargem Bonita no Distrito Federal. Brasília: Universidade de Brasília, 1999. p.99. Dissertação de Mestrado.

MOREIRA, H. S. M. Produtividade, reação a doenças e estimativas de parâmetros genéticos em progênies de maracujazeiro-azedo cultivadas no Distrito Federal. Brasília: 
Faculdade de Agronomia e Medicina Veterinária, Universidade de Brasília-Brasília,2011. p.106. Dissertação de Mestrado.

RANGEL, L.E.P. Desempenho agronômico de nove genótipos de maracujazeiro-azedo cultivados sob três níveis de adubação potássica no Distrito Federal. Brasília: Universidade de Brasília,2002. p.45. Dissertação de mestrado.

SECRETARIA DE AGRICULTURA, IRRIGAÇÃO E REFORMA AGRÁRIA - SEAGRI.

Cultura- maracujá. Salvador, [200-?]. Disponível em: <http://www.seagri.ba.gov.br/Maracuja.htm>. Acesso em: dez. 2013.

TEIXERA, S. T. MERCADO EXPORTADOR - ANÁLISE PARA CULTURA DO

MARACUJÁ. Unesp, 2005. Disponível em:

<http://www.todafruta.com.br/portal/icNoticiaAberta.asp?idNoticia=8543> Acesso em: $11 \mathrm{de}$ Julho de 2011.

SILVA, M. G. M. Seleção recorrente intrapopulacional no maracujazeiro amarelo: Alternativa de capitalização de ganhos genéticos. Ciência e Agrotecnologia, 2009. v. 33, n. 01, p. $170-176$

SOUSA, M.A.F. Avaliação da produtividade, incidência, e severidade de doenças em frutos de 17 genótipos de maracujazeiro-amarelo, cultivados no Distrito Federal. Brasília: Faculdade de Agronomia e Medicina Veterinária, Universidade de Brasília, 2005. p.120. Dissertação (Mestrado em Ciências Agrárias)

. Produtividade e reação de progênies de maracujazeiro azedo a doenças em campo e casa de vegetação. Brasília: Universidade de Brasília, 2009. p. 248. Tese (Doutorado em Fitopatologia).

SOUZA, P.M.; FERREIRA, V.R.; PONCIANO, N.J.; BRITO, M.N. Otimização econômica, sob condições de risco, para agricultores familiares das regiões norte e noroeste do Estado do Rio de Janeiro. Rio de Janeiro: Revista Pesquisa Operacional, 2008. v.28, n.1, p.123-139.

VENCOVSKY, R. Herança quantitativa. In: PATERNIANI, E.; VIEGAS, G. P. (coord.). Melhoramento e produção de milho no Brasil. 2ed. Campinas: Fundação Cargil,1987. p. $137-214$ 
VILELA, M.S. Avaliação de progênies de maracujazeiro-azedo quanto ao desempenho agronômico, resistência a doenças e diversidade genética. Brasília: Faculdade de Agronomia e medicina Veterinária, Universidade de Brasília, 2013. p.181. Tese de Doutorado.

Base de Dados - Estação Automática. Disponível em: http://fav.unb.br/86-faculdadeveterinaria/128-base-de-dados-estacao-automatica-dados-diarios. Acesso em: 26 de junho de 2015. 


\section{CAPITULO 4}

RESISTÊNCIA DE PROGÊNIES DE MARACUJAZEIRO-AZEDO À SEPTORIOSE, ANTRACNOSE E VERRUGOSE, EM CONDIÇÕES DE CAMPO 


\section{RESUMO}

A fruticultura assume importante papel social e econômico, devido à geração de alimentos e empregos, em especial o maracujazeiro por ter grande influência no mercado brasileiro de frutas. No entanto, observa-se baixa produtividade e alta suscetibilidade das cultivares às principais doenças fúngicas. Sendo assim, num programa de melhoramento genético, o desenvolvimento de cultivares resistentes a doenças e produtivas é muito importante. Nesse sentido, esse trabalho teve como objetivo avaliar a reação de quarenta e duas progênies de maracujazeiro-azedo a doenças fúngicas (septoriose, antracnose e verrugose), em condições de campo, no Distrito Federal. Foram utilizadas quarenta e duas progênies, num delineamento de blocos casualizados, com cinco plantas por parcela e quatro repetições. Foram avaliadas, em quatro diferentes épocas (janeiro, março, maio e julho), as progênies: Gig. Amar. Pl.2; FB200; Rosa Int. Pl.1; EC3-0 Pl.1; MSCA; MSCA Pl.1; MSCA P1.2; Gig. Amar. Pl.1; PES 9; Rosa Int.Pl.3; Rosa Claro Pl.3; Rosa Claro Pl.1; Rubi Gig. Pl.1; AR 2; ECL -7; PA 01; RC3; Rosa Int. P1.2; Rosa Claro P1.2; Rubi. Gig. P1.2; EC3-0; AP1; ECRAM P1.3; MAR20\#44; MAR20\#24 Pl.1; MAR20\#24 Pl.2; MAR20\#10; MAR20\#12 Pl.1; MAR20\#12 Pl.2; MAR20\#15; MAR20\#21; MAR20\#19; MAR20\#41; MAR20\#34; MAR20\#39; MAR20\#46 Pl.1; MAR20\#46 Pl.2; MAR20\#2005 Pl.1; MAR20\#2005 Pl.2; MAR20\#2005 Pl.3; MAR20\#2005 Pl.4; e 20\#34 F2. A identificação visual do sintoma das doenças se deve à percepção e à quantificação de lesões na superfície do fruto. Foram realizadas quatro avaliações de severidade e incidência, estimadas de acordo com escala diagramática para a doença específica. Para septoria $76 \%$ das progênies foram classificadas como (MS) e $24 \%$ (MR). Para antracnose todas obtiveram nota média (MR) e para verrugose $62 \%$ das notas foram (MS) e 38\% (MR).Os valores de incidência e severidade para a estimativa de herdabilidade e razão $\mathrm{CVg} / \mathrm{CVe}$ foram altos para as três doenças (septoriose, antracnose e verrugose), mostrado que existe alta variabilidade genética entre as progênies estudadas.

Palavras-chave: passiflora edulis Sims, Septoria passiflora e Cladosporium herbarum. 


\begin{abstract}
The sour passion fruit has great influence in Brazilian fruit market. However, there is low productivity and high susceptibility of current cultivars to fungal diseases. In a breeding program, the development of resistant cultivars to diseases and productive is very important. Thus, this study aimed to evaluate the reaction of 42 passion fruit progenies to fungal diseases (septoria, scab and anthracnose), under field conditions, in Federal District. It was used 42 progenies in a randomized block design, with five plants per plot and four replications. The progenies evaluated were: Gig. Amar. P1.2; FB200; Rosa Int. P1.1; EC3-0 1; MSCA; MSCA Pl.1; MSCA Pl.2; Gig. Amar. Pl.1; PES 9; Rosa Int.Pl.3; Rosa Claro Pl.3; Rosa Claro Pl.1; Rubi Gig. Pl.1; AR 2; ECL -7; PA 01; RC3; Rosa Int. P1.2; Rosa Claro 2; Rubi. Gig. Pl.2; EC3-0; AP 1; ECRAM P1.3; MAR20\#44; MAR20\#24 Pl.1; MAR20\#24 Pl.2; MAR20\#10; MAR20\#12 Pl.1; MAR20\#12 Pl.2; MAR20\#15; MAR20\#21; MAR20\#19; MAR20\#41; MAR20\#34; MAR20\#39; MAR20\#46 Pl.1; MAR20\#46 Pl.2; MAR20\#2005 Pl.1; MAR20\#2005 P1.2; MAR20\#2005 P1.3; MAR20\#2005 P1.4; $20 \# 34$ F2. The visual identification of symptom of disease was due to the perception and quantification of the lesions on the surface of the fruit. Four evaluations of severity and incidence were held, estimated according to diagrammatic scale. For septoria $76 \%$ of the progenies were classified as MS and 24\% MR. For anthracnose all obtained average grade MR. For scab, $62 \%$ of the notes were MS and 38\% were MR. The incidence and severity values for estimating heritability and reason $\mathrm{CVg} / \mathrm{CVe}$ were high for the three diseases (Septoria, anthracnose and scab), showing that there is high genetic variability among progenies.
\end{abstract}

Keywords: passiflora edulis Sims, Septoria passifloraand Cladosporium herbarum. 


\section{1 - INTRODUÇÃO}

O Brasil vem se destacando como um grande produtor de maracujá, sendo a produção estimada em 920.000 toneladas, com área cultivada correspondente a 62.200 hectares por ano (IBGE, 2013). De acordo com JUNQUEIRA et al., (1999), a produtividade da cultura do maracujá é considerada baixa, sendo que o cultivo de variedades inadequadas é um dos fatores que influenciam essa característica. Outros fatores se referem a características genéticas da planta, condições edáficas, ambientais, agentes bióticos e a ação do homem (LIMA \& BORGE, 2002).

É perceptível que há uma carência de materiais genéticos com alta produtividade, qualidade de frutos e resistência a fitopatógenos, em razão, principalmente, da falta de trabalhos de pesquisa nas diversas áreas do conhecimento e especialmente com melhoramento genético do maracujazeiro.

Segundo MELETTI et al (2005), o melhoramento genético do maracujazeiro tem diversas finalidades em função do produto a ser considerado (frutos, folhas ou sementes) e da região de cultivo. $\mathrm{O}$ aumento da produtividade, qualidade química e física dos frutos, vigor, longevidade das plantas, produção na entressafra, adaptabilidade e a resistência a doenças, aos nematoides são os principais objetivos do melhoramento da cultura.

No que diz respeito a fitopatógenos que atacam a cultura do maracujazeiro-azedo destacam-se as doenças causadas por fungos, bactérias e por vírus que afetam o sistema radicular e a parte aérea (SANTOS FILHO \& JUNQUEIRA, 2003). Entre essas, destacam-se a septoriose (Septoria passiflorae), a antracnose (Colletotrichum gloeosporioides) e a verrugose (Cladosporium spp.) (RUGGIERO et al., 1996) como doenças fúngicas principais.

A septoriose é uma doença causada pelo fungo Septoria passiflorae, podendo ocorrer em todas as regiões produtoras do Brasil. É considerada uma doença importante em pomares de maracujá-azedo na região dos cerrados. No entanto, segundo FISCHER et al. (2005), danos significativos ocorrem somente esporadicamente nas regiões produtoras, principalmente quando o controle químico preventivo é deficiente em viveiros e lavouras.

A antracnose é causada pelo fungo Colletotrichum gloeosporioides e é uma das doenças de maior expressão econômica, tanto para o maracujazeiro-azedo quanto para o roxo ou doce, afetando folhas, ramos novos e frutos, principalmente frutos desenvolvidos, sendo importante para pós-colheita, já que reduz o período de conservação dos frutos.

A cladosporiose, também denominada verrugose, é causada pelo fungo Cladosporium herbarum e pode afetar a maioria das Passifloraceas. Sua importância concentra-se em grande 
parte voltada ao comércio da fruta in natura, pois implica um aspecto verrugoso à superfície dos frutos.

As utilizações de cultivares resistentes, em conjunto com outras técnicas de manejo integrado, são medidas eficazes, ecológicas e econômicas utilizadas no controle de doenças em plantas. Observando as características do maracujazeiro de baixa produtividade e alta suscetibilidade das cultivares atuais às principais doenças fúngicas, a estratégia de desenvolvimento de cultivares resistentes a doenças e produtivas é muito importante num programa de melhoramento genético da cultura (JUNQUEIRA et al., 2003; FALEIRO et al., 2005).

Estudos detalhados de caracterização, seleção e hibridação de genótipos de maracujazeiro são essenciais para subsidiar a utilização do germoplasma de Passiflora em programas de melhoramento genético e na obtenção de materiais produtivos, com boa qualidade de frutos e com resistência ou tolerância aos principais fitopatógenos do maracujazeiro-azedo.

Nesse sentido, esse trabalho teve como objetivo avaliar a reação de quarenta e duas progênies de maracujazeiro-azedo às doenças fúngicas (septoriose, antracnose e verrugose), em condições de campo.

\section{2 - MATERIAL E MÉTODOS}

O trabalho foi realizado na Fazenda Água Limpa, pertencente à Universidade de Brasília (UnB), situada na Vargem Bonita, $25 \mathrm{~km}$ ao sul do Distrito Federal, com latitude de $16^{\circ} \mathrm{Sul}$, longitude de $48^{\circ}$ Oeste e $1.100 \mathrm{~m}$ de altitude. O clima da região é caracterizado por chuvas concentradas no verão, de outubro a abril, e invernos secos, de maio a setembro (MELO, 1999).

O experimento foi instalado em solo Latossolo Vermelho-Amarelo, fase argilosa, profundo, com boa drenagem. Na área experimental foi realizada a calagem e a incorporação de $1 \mathrm{~kg}$ de superfosfato simples por cova em pré-plantio. A análise de solo apresentou os seguintes resultados: $\mathrm{Al}$ (0,05 meq); $\mathrm{Ca}+\mathrm{Mg}$ (1,9 meq); $\mathrm{P}$ (4,5 ppm); K (46 ppm); pH 5,4 e saturação de $\mathrm{Al} 4 \%$. As adubações de cobertura foram realizadas em círculo, à distância de quarenta a cinquenta centímetros do colo da planta superficialmente, enquanto o superfosfato simples foi incorporado no solo.

Foram utilizadas quarenta e duas progênies, num delineamento de blocos casualizados, com cinco plantas por parcela e quatro repetições. As progênies utilizadas foram: Gig. Amar. Pl.2; FB200; Rosa Int. Pl.1; EC3-0 Pl.1; MSCA; MSCA Pl.1; MSCA P1.2; Gig. Amar. Pl.1; 
PES 9; Rosa Int.P1.3; Rosa Claro Pl.3; Rosa Claro Pl.1; Rubi Gig. Pl.1; AR 2; ECL -7; PA 01; RC3; Rosa Int. Pl.2; Rosa Claro Pl.2; Rubi. Gig. Pl.2; EC3-0; AP1; ECRAM Pl.3; MAR20\#44; MAR20\#24 Pl.1; MAR20\#24 Pl.2; MAR20\#10; MAR20\#12 Pl.1; MAR20\#12 P1.2; MAR20\#15; MAR20\#21; MAR20\#19; MAR20\#41; MAR20\#34; MAR20\#39; MAR20\#46 Pl.1; MAR20\#46 Pl.2; MAR20\#2005 Pl.1; MAR20\#2005 Pl.2; MAR20\#2005 P1.3; MAR20\#2005 Pl.4; e 20\#34 F2. Essas progênies foram desenvolvidas a partir de trabalhos de pesquisa desenvolvidos pela Universidade de Brasília - UnB e Embrapa Cerrados. Têm origem de hibridações intra-específicas e interespecíficas e também de materiais oriundos de seleção massal feita em pomares produtivos da região sudeste do Brasil.

Os materiais MAR20\#44; MAR20\#24 (Pl 1 e 2); MAR20\#12 (Pl 1 e 2); MAR20\#21; MAR20\#19; MAR20\#41; MAR20\#39; MAR20\#46 (Pl 1, 2 e 3) e MAR20\#2005 (Pl 1, 2,3 e 4) foram obtidos por seleção massal de plantios comerciais contendo nove materiais superiores, considerando os aspectos de produtividade, qualidade de frutos e resistência aos patógenos, trazidos do município de Araguari, descritos na Tabela 25.

Tabela 25 - Progênies cultivadas em pomares comerciais no município de Araguari/MG, utilizados na seleção massal.

\begin{tabular}{|l|l|}
\hline 1 & Maguary "Mesa 1" \\
\hline 2 & Maguary "Mesa 2" \\
\hline 3 & Havaiano \\
\hline 4 & Marília Seleção Cerrado (MSC) \\
\hline 5 & Seleção DF \\
\hline 6 & EC-2-O \\
\hline 7 & $\mathrm{~F}_{1}$ (Marília x Roxo Australiano) \\
\hline 8 & $\mathrm{~F}_{1}[$ Roxo Fiji (introdução das ilhas Fiji) x Marília] \\
\hline 9 & $\begin{array}{l}\text { RC } C_{1}\left[F_{1}(\text { Marília (seleção da Cooperativa sul Brasil de Marília }- \text { SP) x Roxo }\right. \\
\text { Australiano) x Marília (pai recorrente)] }\end{array}$ \\
\hline
\end{tabular}

As progênies MAR20\#10 e MAR20\#15 foram obtidas através de sementes coletadas do campo experimental da Fazenda Água Limpa (FAL) - UnB- 2012. 
Os materiais denominados FB-200, Rosa Int., EC3-0 P1.1, MSCA, PES 9, Rosa Claro, Rubi Gig, AR 2, ECL -7, PA 01, RC3, AP1 e ECRAM 2 foram obtidos conforme descrito na Tabela 26.

Tabela 26 - Procedência de progênies de maracujazeiro-azedo avaliados no Distrito Federal, Fazenda Água Limpa - UnB, 2012 e 2013.

\begin{tabular}{|c|l|}
\hline PROGÊNIES & \multicolumn{1}{|c|}{ ORIGEM } \\
\hline FB200 & Cultivar comercial \\
\hline Rosa Int. & Seleção recorrente baseada na família de meio irmãos \\
\hline EC 3-0 1 & $\begin{array}{l}\text { Híbrido }\left(\mathrm{RC}_{1}\right) \text { de polinização controlada entre as cultivares Marília x Roxo } \\
\text { Australiano retrocruzado para Marília, ou seja } \mathrm{F}_{1} \text { x Marília }\end{array}$ \\
\hline MSCA & Marília seleção cerrado \\
\hline PES 9 & $\begin{array}{l}\text { Oriundos da geração } \mathrm{F}_{3} \text { de polinização controlada entre as espécies } P \text {. edulis } \\
\text { e } P \text {. setaceae }\end{array}$ \\
\hline Rosa Claro & Seleção recorrente baseada na família de meio irmãos \\
\hline MAR 20\#01 & $\begin{array}{l}\text { Seleção recorrente baseada em família de 1/2 irmãos entre diversos } \\
\text { genótipos de Passiflora edulis }\end{array}$ \\
\hline MAR 20\#02 & $\begin{array}{l}\text { Seleção recorrente baseada em família de 1/2 irmãos entre diversos } \\
\text { genótipos de } \text { Passiflora edulis }\end{array}$ \\
\hline Rubi Gig & (Roxo australiano x Marília) \\
\hline AR 2 & $\begin{array}{l}\text { Seleção individual de plantas resistentes à antracnose de uma população de } \\
\text { Roxo Australiano }\end{array}$ \\
\hline ECL -7 & Derivado da cultivar Marília \\
\hline PA 01 & Seleção recorrente baseada na família de meio irmãos \\
\hline RC3 & Híbrido de seleção recorrente (P. edulis x P. setacea) \\
\hline EC3-0 & $\begin{array}{l}\text { Híbrido (RC1) de polinização controlada entre as cultivares Marília x Roxo } \\
\text { Australiano retrocruzado para Marília, ou seja, F1 x Marília }\end{array}$ \\
\hline AP1 & $\begin{array}{l}\text { Cultivar obtida do cruzamento entre tipos de maracujá-amarelo de alta } \\
\text { produtividade, selecionados em pomar comercial }\end{array}$ \\
\hline ECRAM 2 & Híbrido entre roxo australiano ( $P$. edulis ) x P. edulis f. flavicarpa \\
\hline
\end{tabular}

As mudas foram obtidas por meio de semeadura em bandejas com setenta e duas células com $125 \mathrm{ml}$ de substrato vermiculita em junho de 2012, sob casa de vegetação localizada na Estação Biológica - UnB. As mudas foram transplantadas para o campo em outubro de 2011, com adubação de $700 \mathrm{~g}$ de superfosfato simples por cova. $\mathrm{O}$ espaçamento utilizado foi de dois metros e oitenta centímetros entre linhas e três metros entre plantas, totalizando 1.190 plantas por hectare.

A suplementação de água foi feita via sistema de irrigação, sendo realizada da seguinte forma: sete horas de irrigação e um turno de dois dias com média de três litros por metro linear por hora.

Para o plantio, foram aplicados $700 \mathrm{~g}$ de superfosfato simples e $200 \mathrm{~g}$ de calcário dolomítico por cova, além de quatro adubações com intervalo de quinze dias com $200 \mathrm{~g}$ de 
sulfato de amônio e $100 \mathrm{~g}$ de cloreto de potássio. Após o plantio foram realizadas adubações com periodicidade de quinze dias. Os níveis de adubação de potássio e nitrogênio foram: 100 $\mathrm{g}$ de sulfato de amônio (20 g de nitrogênio) e $70 \mathrm{~g}$ de cloreto de potássio (40 g de $\mathrm{K}_{2} \mathrm{O}$ ). Para a adubação de fósforo, aplicou-se $650 \mathrm{~g} /$ cova de supersimples $\left(117 \mathrm{~g}\right.$ de $\left.\mathrm{P}_{2} \mathrm{O}_{5}\right)$ e $250 \mathrm{~g} /$ cova do mesmo adubo (45 $\mathrm{g} \mathrm{P}_{2} \mathrm{O}_{5}$ ). As adubações de cobertura foram realizadas em círculo, à distância de 40 a $50 \mathrm{~cm}$ do colo da planta superficialmente, porém o superfosfato simples foi incorporado no solo. Entre setembro, outubro, novembro, dezembro de 2012 e janeiro de 2013, foram realizadas aplicações de adubo via fertirrigação da seguinte forma: $62,5 \mathrm{~g} /$ cova de ureia (30 g/cova de nitrogênio), $100 \mathrm{~g} /$ cova de cloreto de potássio branco (60 g/cova de $\mathrm{K}_{2} \mathrm{O}$ ) e $200 \mathrm{~g} /$ cova de nitrabor (30 g/cova de nitrogênio, $40 \mathrm{~g} /$ cova de cálcio e $0,4 \mathrm{~g} /$ cova de boro).

Foi feita adubação foliar com (N-P-K) 4-16-16 e micronutrientes a $600 \mathrm{ml}$ em vinte litros de água, totalizando a aplicação de 140 litros/ha de calda, com bomba costal. Para o controle das lagartas Dione juno Juno, Agraulis vanillae vanillae e percevejos, foi realizada uma aplicação de Decis ${ }^{\circledR}(500 \mathrm{ml} / \mathrm{ha})$ adicionado de 1 litro/ha de óleo mineral Assist ${ }^{\circledR}$ em janeiro de 2013. E para o controle de ácaro, e também com efeito sobre esses insetos, foi feita uma aplicação de Vexter® (abamectina) a $100 \mathrm{ml} / \mathrm{ha}$ com óleo mineral Iharol® 1 litro/ha em julho de 2012. O controle das plantas daninhas na linha foi feito com aplicação de glifosato (200 $\mathrm{ml}$ ) mais $50 \mathrm{~g}$ de ureia por bomba costal de vinte litros.

A lavoura foi conduzida utilizando o sistema de sustentação de espaldeira vertical, com mourões distanciados de seis metros e dois fios de arame liso a dois metros de altura e outro a um metro e meio em relação ao solo. As plantas foram conduzidas em haste única, tutoradas por barbante até o arame, deixando para fio de arame duas brotações laterais em sentido contrário uma a outra. As brotações, a partir daí, cresceram livremente, não tendo sido realizadas podas de renovação.

As colheitas foram realizadas somente dos frutos que se encontravam no chão, ou seja, a partir de sua maturação total. Os frutos colhidos aleatoriamente eram colocados em caixas de plástico e separados para avaliação visual dos sintomas das doenças que se deve à percepção e à quantificação de lesões na superfície do fruto, utilizando a margem de representação de dez frutos por parcela. Não houve inoculação dos patógenos, sendo considerada a pressão de inóculo natural, sob condições de campo. O período de avaliações ocorreu de janeiro a agosto de 2013, totalizando em quatro avaliações nas épocas descritas a seguir. 


\begin{tabular}{|c|c|}
\hline ÉPOCA & MÊS-ANO \\
\hline 1 & Janeiro-Fevereiro de 2013 \\
\hline 2 & Março-Abril de 2013 \\
\hline 3 & Maio-Junho de 2013 \\
\hline 4 & Julho-Agosto de 2013 \\
\hline
\end{tabular}

O grau de resistência à septoriose e à antracnose foi avaliado utilizando-se a escala de notas criada por JUNQUEIRA et al., (2003). Dessa forma, o grau de resistência à septoriose e à antracnose foi obtido utilizando a escala de notas como mostra a Tabela 27.

Tabela 27 - Notas e sintomas visuais utilizados para análise dos frutos de quarenta e duas progênies de maracujazeiro-azedo, proposta por JUNQUEIRA et al., (2003).

\begin{tabular}{|c|l|l|}
\hline NOTAS & \multicolumn{1}{|c|}{ DESCRIÇÃO } & \multicolumn{1}{|c|}{ CLASSIFICAÇÃO } \\
\hline 1 & Sem sintomas de doenças & Resistentes (R) \\
\hline 2 & $\begin{array}{l}\text { Até 10\% da superfície coberta por } \\
\text { lesões }\end{array}$ & $\begin{array}{l}\text { Moderadamente resistentes } \\
\text { (MR) }\end{array}$ \\
\hline 3 & $\begin{array}{l}10,01 \% \text { a } 30 \% \text { da sup. coberta por } \\
\text { lesões }\end{array}$ & Suscetíveis (S) \\
\hline 4 & $\begin{array}{l}\text { Maior 30,01\% da sup. coberta por } \\
\text { lesões }\end{array}$ & Altamente suscetíveis (AS) \\
\hline
\end{tabular}

Quanto à verrugose, a avaliação foi de acordo com a escala de notas criada por JUNQUEIRA et al., (2003), modificada por SOUZA, (2005) onde a percentagem da superfície do fruto coberta por lesões foi identificada para a contagem do número de lesões nos frutos. Dessa forma, o grau de resistência da verrugose foi obtido utilizando a escala de notas descrita a seguir: Atribuiu nota 1 para frutos sem nenhuma lesão, ou seja, zero lesão, Resistente (R); nota 2: Maior que $1<5$ lesões, moderadamente suscetíveis (MS); nota 3: os frutos apresentam mais que cinco e menos do que dez lesões, suscetível (S) e nota 4: os frutos que apresentam mais que dez lesões, altamente suscetíveis (AS) como mostra a Tabela 28.

Tabela 28 - Notas e sintomas visuais utilizadas para análise dos frutos de quarenta e duas progênies de maracujazeiro-azedo, proposta por JUNQUEIRA et al., (2003) e adaptado por SOUSA, (2005).

\begin{tabular}{|c|c|c|}
\hline NOTAS & DESCRIÇÃO & CLASSES \\
\hline 1 & Sem verrugas & Resistente $(\mathrm{R})$ \\
\hline 2 & $1<5$ lesões (verrugas) & Moderadamente suscetível \\
& & (MS) \\
\hline 3 & $>5 \mathrm{e}<10$ lesões (verrugas) & Suscetível $(\mathrm{S})$ \\
\hline
\end{tabular}




\begin{tabular}{|c|c|c|c|}
\hline 4 & $>10$ lesões (verrugas) & \multicolumn{2}{c|}{ Altamente suscetível (AS) } \\
\hline As análises estatísticas foram realizadas com o auxílio dos softwares SISVAR
\end{tabular}
(FERREIRA, 2000) e GENES (CRUZ, 2007).

Os dados sem transformação foram submetidos à análise de variância, utilizando para o teste de F o nível de 5\% de probabilidade. As médias foram agrupadas pelo teste de ScottKnott (FERREIRA, 2000).

A partir dos dados observados nas avaliações da severidade da septoriose, antracnose e verrugose, foi obtida a curva do progresso das doenças e então calculada a área (AACPD) (Tabela 35).

\section{3 - RESULTADOS E DISCUSSÃO}

\section{A - SEPTORIOSE}

Houve diferença estatística para incidência nas épocas 1, 2 e 4. Sendo que nas épocas 1 , 3 e 4, a progênie EC3-0 Pl.1 teve todos os seus frutos atacados pelo patógeno (Tabela 29).

Na $2^{\mathrm{a}}$ época, as progênies MAR20\#2005 Pl.1, AR2, ECRAM Pl.2, GAZ Pl.1, Gig. Amar. Pl.2, Gig. Amar. Pl.3, MAR20\#12 Pl.2, MAR20\#24 Pl.1, MAR 20\#34, MAR20\#41, MSCA P1.2, Rosa Int. P1.2 e Rubi Gig. P1.2 tiveram todos os seus frutos atacados pelo patógeno.

$\mathrm{Na} 3^{\mathrm{a}}$ época, não houve diferença estatística quanto à incidência da doença nos frutos, tendo todas as progênies incidência do patógeno entre (75-100\%) não sendo diferente em termos de percentagem para a $4^{\mathrm{a}}$ época mesmo tendo ocorrido diferença estatística.

COIMBRA (2010), trabalhando com vinte e seis progênies de maracujazeiro-azedo, em condições de campo, observou máxima incidência de septoriose de 93,25\% em AR01 e FB200.

SOUSA (2009) em trabalho de campo no Distrito Federal encontrou em MAR20\#21 a maior incidência, 70,66\%, enquanto a progênie ECL-7 obteve 49,54\% de frutos com sintomas. BOUZA (2009) trabalhando com materiais semelhantes aos desse experimento, verificou a incidência de septoriose nos materiais avaliados oscilando de $91,04 \%$ em MAR20\#46 a $75 \%$ em ECRAM.

VILELA (2013) em trabalho de campo, verificou incidência média de 69,75\% para MAR20\#46 e 72,50\% para ECRAM. No presente experimento, a progênie MAR20\#46 apresentou incidência média de $65,31 \%$, valor bem próximo ao trabalho mencionado. 
Podemos observar que as progênies Gig. Amar. Pl.3 e MAR20\#46 diferiram significativamente de todas as outras progênies na $1^{\text {a }}$ época por ter apresentado baixa incidência de frutos atacados num percentual entre 10 e $15 \%$.

Em estudo semelhante realizado por BOUZA (2009) percebeu-se diferenças significativas em relação ao tempo, ou seja, quanto às épocas nas progênies AR 02 , MAR20\#03, MAR20\#36 e RC3 e no presente estudo foi verificado que houve diferença estatística tanto para incidência quanto para severidade nas várias épocas apresentadas nas Tabelas 29 e 30 .

A $3^{\text {a }}$ época apresentou as melhores condições para as progênies permanecerem tolerantes quando comparada com as épocas 1, 2 e 4 (Tabela 30).

Também no estudo de BOUZA (2009) para severidade em condições de campo, as progênies ECRAM, PCF-2; GA-2 e AR 01 foram consideradas menos suscetíveis e as outras oito progênies foram consideradas moderadamente suscetíveis (MS).

As progênies EC3-0 Pl.1, Gigante Amar. P1.3 e MSCA Pl.2, como mostra a Tabela 28, foram as que mais sofreram o ataque do patógeno nos frutos, visto que em três das quatro épocas apresentaram $100 \%$ de frutos atacados.

As progênies MAR20\#2005 Pl.1, ECRAM P1.2, GAZ Pl.1, Gig. Amar. Pl.2, MAR20\#24 Pl.1, MAR20\#39, MAR20\#41, MAR20\#44, MSCA, Rosa Claro Pl.1 e Rosa Int. Pl.1 não diferiram ao longo das quatro épocas do experimento.

$\mathrm{Na} 1^{\mathrm{a}}$ época, as progênies apresentaram baixa resistência, com o passar do tempo, foi observado que o efeito ambiental (radiação solar, temperatura média, umidade relativa etc) pode ter tido interferência na maior ou na menor incidência e severidade das doenças, e então passaram a ser mais tolerantes no decorrer das épocas.

BOUZA (2009) obteve índice de severidade máxima em AR02 com 1,89\% e menor severidade em ECRAM com 1,38\%.

SOUSA (2009) encontrou diferença estatística onde as progênies FB200 e MAR20\#12 apresentaram a maior severidade de $3,42 \%$ e 3,40\%, respectivamente, e a progênie MAR20\#44 apresentou a menor severidade, 1,76\%.

Das quarenta e duas progênies em média, 76\% foram consideradas moderadamente suscetíveis (MS) e 24\% moderadamente resistente (MR) de acordo com JUNQUEIRA (2003), com modificações.

Quanto à severidade, a progênie Gigante Amar. Pl.3 apresentou 1,10\% do fruto coberto por lesão sendo a menor percentagem e as progênies EC3-0 Pl.1 e Rosa Claro Pl.1 
apresentaram $2,71 \%$ da superfície do fruto coberto por lesão sendo a maior percentagem (Tabela 30).

Tabela 29 - Incidência (\%) de septoriose nas quatro diferentes épocas em quarenta e duas progênies de maracujazeiro-azedo.

\begin{tabular}{|c|c|c|c|c|c|}
\hline \multicolumn{6}{|c|}{ SEPTORIA (INCIDÊNCIA) } \\
\hline PROGÊNIES & 1 & 2 & 3 & 4 & MÉDIA \\
\hline MAR20\#2005 Pl.1 & $80,00 \mathrm{aC}$ & $83,75 \mathrm{aA}$ & $90,00 \mathrm{aA}$ & $90,00 \mathrm{aA}$ & 85,94 \\
\hline MAR20\#2005 Pl.2 & $77,50 \mathrm{aC}$ & $75,00 \mathrm{aA}$ & $86,67 \mathrm{aA}$ & $100,00 \mathrm{bB}$ & 84,79 \\
\hline MAR20\#2005 Pl.3 & $77,77 \mathrm{aC}$ & $75,63 \mathrm{aA}$ & $96,67 \mathrm{bA}$ & $100,00 \mathrm{bB}$ & 87,52 \\
\hline MAR20\#2005 Pl.4 & $63,33 \mathrm{aB}$ & $100,00 \mathrm{bB}$ & $92,50 \mathrm{bA}$ & $75,00 \mathrm{aA}$ & 82,71 \\
\hline $20 \# 34$ F2 & $83,33 \mathrm{aD}$ & $95,00 \mathrm{bB}$ & $100,00 \mathrm{bA}$ & $100,00 \mathrm{bA}$ & 94,58 \\
\hline AP 01 & $62,50 \mathrm{aB}$ & $86,66 \mathrm{bB}$ & $95,00 \mathrm{bA}$ & $100,00 \mathrm{bB}$ & 86,07 \\
\hline AR 2 & $60,00 \mathrm{aB}$ & $100,00 \mathrm{bB}$ & $96,67 \mathrm{bA}$ & $90,00 \mathrm{bA}$ & 86,67 \\
\hline EC3-0 & $78,75 \mathrm{aC}$ & $82,50 \mathrm{aA}$ & $100,00 \mathrm{bA}$ & $90,00 \mathrm{bA}$ & 87,81 \\
\hline EC3-0 Pl.1 & $100,00 \mathrm{bD}$ & $66,66 \mathrm{aA}$ & $100,00 \mathrm{bA}$ & $100,00 \mathrm{bB}$ & 91,67 \\
\hline ECL 7 & $75,00 \mathrm{aC}$ & $78,93 \mathrm{aA}$ & $93,33 \mathrm{bA}$ & $90,00 \mathrm{bA}$ & 84,32 \\
\hline ECRAM PI.2 & $85,00 \mathrm{aD}$ & $100,00 \mathrm{aB}$ & $90,00 \mathrm{aA}$ & $100,00 \mathrm{aB}$ & 93,75 \\
\hline ECRAM PI.3 & $70,00 \mathrm{aC}$ & $75,18 \mathrm{aA}$ & $100,00 \mathrm{bA}$ & $90,00 \mathrm{bA}$ & 83,80 \\
\hline FB 200 & $61,74 \mathrm{aB}$ & $75,00 \mathrm{aA}$ & $100,00 \mathrm{bA}$ & $100,00 \mathrm{bB}$ & 84,19 \\
\hline GAZ PI.1 & $85,71 \mathrm{aD}$ & $100,00 \mathrm{aB}$ & $100,00 \mathrm{aA}$ & $96,67 \mathrm{aB}$ & 95,60 \\
\hline Gig. Amar Pl.1 & $80,00 \mathrm{aC}$ & $75,00 \mathrm{aA}$ & $100,00 \mathrm{bA}$ & $100,00 \mathrm{bB}$ & 88,75 \\
\hline Gig. Amar Pl.2 & $88,88 \mathrm{aD}$ & $100,00 \mathrm{aB}$ & $100,00 \mathrm{aA}$ & $95,00 \mathrm{aB}$ & 95,97 \\
\hline Gig. Amar Pl.3 & $10,00 \mathrm{aA}$ & $100,00 \mathrm{bB}$ & $100,00 \mathrm{bA}$ & $100,00 \mathrm{bB}$ & 77,50 \\
\hline MAR 20\#10 & $95,00 \mathrm{bD}$ & $76,67 \mathrm{aA}$ & $90,00 \mathrm{bA}$ & $90,00 \mathrm{bA}$ & 87,92 \\
\hline MAR20\#12 Pl. 2 & $70,00 \mathrm{aC}$ & $100,00 \mathrm{bB}$ & $90,00 \mathrm{bA}$ & $86,67 \mathrm{bA}$ & 86,67 \\
\hline MAR20\#15 & $60,00 \mathrm{aB}$ & $93,33 \mathrm{bB}$ & $90,00 \mathrm{bA}$ & $100,00 \mathrm{bB}$ & 85,83 \\
\hline MAR20\#19 & $70,00 \mathrm{aC}$ & $94,44 \mathrm{bB}$ & $92,50 \mathrm{bA}$ & $100,00 \mathrm{bB}$ & 89,24 \\
\hline MAR20\#24 PI.1 & $90,00 \mathrm{aD}$ & $100,00 \mathrm{aB}$ & $100,00 \mathrm{aA}$ & $95,00 \mathrm{aB}$ & 96,25 \\
\hline MAR20\#24 PI.2 & $65,72 \mathrm{aB}$ & $95,00 \mathrm{bB}$ & $100,00 \mathrm{bA}$ & $100,00 \mathrm{bB}$ & 90,18 \\
\hline MAR20\#34 & $52,50 \mathrm{aB}$ & $100,00 \mathrm{bB}$ & $100,00 \mathrm{bA}$ & $90,00 \mathrm{bA}$ & 85,63 \\
\hline MAR20\#39 & $85,24 \mathrm{aD}$ & $78,88 \mathrm{aA}$ & $96,67 \mathrm{aA}$ & $90 \mathrm{aA}$ & 87,70 \\
\hline MAR20\#41 & $88,75 \mathrm{aD}$ & $100,00 \mathrm{aB}$ & $92,50 \mathrm{aA}$ & $96,67 \mathrm{aB}$ & 94,48 \\
\hline MAR20\#44 & $96,66 \mathrm{aD}$ & $92,59 \mathrm{aB}$ & $90,00 \mathrm{aA}$ & $90,00 \mathrm{aA}$ & 92,31 \\
\hline MAR20\#44 PI.1 & $45,00 \mathrm{aB}$ & $70,00 \mathrm{bA}$ & $100,00 \mathrm{BA}$ & $90,00 \mathrm{cA}$ & 76,25 \\
\hline MAR20\#46 & $15,50 \mathrm{aA}$ & $70,72 \mathrm{bA}$ & $95,00 \mathrm{cA}$ & $80,00 \mathrm{bA}$ & 65,31 \\
\hline MAR20\#46 PI.1 & $50,00 \mathrm{aB}$ & $55,00 \mathrm{aA}$ & $83,33 \mathrm{bA}$ & $85,00 \mathrm{bA}$ & 68,33 \\
\hline MAR20\#46 PI.2 & $50,37 \mathrm{aB}$ & $70,83 \mathrm{bA}$ & $90,00 \mathrm{cA}$ & $93,33 \mathrm{cA}$ & 76,13 \\
\hline MSCA & $80,00 \mathrm{aC}$ & $78,79 \mathrm{aA}$ & $86,67 \mathrm{aA}$ & $90,00 \mathrm{aA}$ & 83,87 \\
\hline MSCA PI.1 & $89,63 \mathrm{bD}$ & $70,00 \mathrm{aA}$ & $90,00 \mathrm{bA}$ & $92,50 \mathrm{bA}$ & 85,53 \\
\hline MSCA PI.2 & $81,66 \mathrm{aC}$ & $100,00 \mathrm{bB}$ & $100,00 \mathrm{bA}$ & $100,00 \mathrm{bB}$ & 95,42 \\
\hline PA 01 & $80,00 \mathrm{aC}$ & $75,92 \mathrm{aA}$ & $100,00 \mathrm{bA}$ & $90,00 \mathrm{bA}$ & 86,48 \\
\hline RC 3 & $71,43 \mathrm{aC}$ & $85,71 \mathrm{bA}$ & $100,00 \mathrm{cA}$ & $100,00 \mathrm{cB}$ & 89,29 \\
\hline Rosa Claro Pl.1 & $85,71 \mathrm{aD}$ & $83,33 \mathrm{aA}$ & $93,33 \mathrm{aA}$ & $90,00 \mathrm{aA}$ & 88,09 \\
\hline Rosa Int Pl.1 & $80,00 \mathrm{aC}$ & $87,22 \mathrm{aB}$ & $92,50 \mathrm{aA}$ & $90,00 \mathrm{aA}$ & 87,43 \\
\hline Rosa Int PI.2 & $80,83 \mathrm{aC}$ & $100,00 \mathrm{bB}$ & $95,00 \mathrm{bA}$ & $96,67 \mathrm{bB}$ & 93,13 \\
\hline Rosa Int PI.3 & $57,14 \mathrm{aB}$ & $80,00 \mathrm{bA}$ & $95,00 \mathrm{cA}$ & $100,00 \mathrm{cB}$ & 83,04 \\
\hline
\end{tabular}




\begin{tabular}{|l|l|r|r|r|r|}
\hline Rubi Gig. Pl.1 & $60,00 \mathrm{aB}$ & $75,00 \mathrm{bA}$ & $95,00 \mathrm{cA}$ & $100,00 \mathrm{cB}$ & 82,50 \\
\hline Rubi Gig. Pl.2 & $58,33 \mathrm{aB}$ & $100,00 \mathrm{bB}$ & $100,00 \mathrm{bA}$ & $96,67 \mathrm{bB}$ & 88,75 \\
\hline
\end{tabular}

*Médias seguidas pela mesma letra, minúsculas, nas linhas e maúsculas, nas colunas, não diferem estatisticamente, entre si, pelo teste de Scott Knott ao nível de 5\%.

Tabela 30 - Severidade de septoriose nas quatro diferentes épocas em quarenta e duas progênies de maracujazeiro-azedo.

\begin{tabular}{|c|c|c|c|c|c|}
\hline \multicolumn{6}{|c|}{ SEPTORIA (SEVERIDADE) } \\
\hline PROGÊNIES & 1 & 2 & 3 & 4 & MÉDIA - GR \\
\hline MAR20\#2005 Pl.1 & $2,07 \mathrm{aD}$ & $2,32 \mathrm{aC}$ & $2,13 \mathrm{aA}$ & $1,95 \mathrm{aA}$ & $2,1 \mathrm{MS}$ \\
\hline MAR20\#2005 Pl.2 & $2,15 \mathrm{bE}$ & $1,74 \mathrm{aA}$ & $2,00 \mathrm{bA}$ & $2,20 \mathrm{bB}$ & $2,0 \mathrm{MS}$ \\
\hline MAR20\#2005 PI.3 & $1,99 \mathrm{aD}$ & $1,93 \mathrm{aA}$ & $2,07 \mathrm{aA}$ & $2,17 \mathrm{aB}$ & $2,0 \mathrm{MS}$ \\
\hline MAR20\#2005 Pl.4 & $1,63 \mathrm{aB}$ & $2,17 \mathrm{bB}$ & $2,17 \mathrm{bA}$ & $1,95 \mathrm{bA}$ & $1,9 \mathrm{MR}$ \\
\hline $20 \# 34$ F2 & $1,92 \mathrm{aD}$ & $2,05 \mathrm{aB}$ & $2,10 \mathrm{aA}$ & $2,30 \mathrm{aB}$ & $2,1 \mathrm{MS}$ \\
\hline AP 01 & $1,62 \mathrm{aB}$ & $1,92 \mathrm{bA}$ & $2,15 \mathrm{cA}$ & $2,20 \mathrm{cB}$ & $2,0 \mathrm{MS}$ \\
\hline AR 2 & $2,00 \mathrm{aD}$ & $3,30 \mathrm{cE}$ & $2,30 \mathrm{bB}$ & $1,90 \mathrm{aA}$ & $2,4 \mathrm{MS}$ \\
\hline EC3-0 & $1,95 \mathrm{aD}$ & $2,09 \mathrm{aB}$ & $2,20 \mathrm{aA}$ & $2,08 \mathrm{aA}$ & $2,1 \mathrm{MS}$ \\
\hline EC3-0 PI.1 & $2,70 \mathrm{cE}$ & $1,83 \mathrm{aA}$ & $2,50 \mathrm{cB}$ & $2,30 \mathrm{bB}$ & $2,3 \mathrm{MS}$ \\
\hline ECL 7 & $2,30 \mathrm{bE}$ & $2,23 \mathrm{bC}$ & $2,03 \mathrm{aA}$ & $1,90 \mathrm{aA}$ & $2,1 \mathrm{MS}$ \\
\hline ECRAM PI.2 & $2,00 \mathrm{aD}$ & $2,30 \mathrm{bc}$ & $2,10 \mathrm{aA}$ & $2,35 \mathrm{bB}$ & $2,2 \mathrm{MS}$ \\
\hline ECRAM PI.3 & $2,00 \mathrm{aD}$ & $2,06 \mathrm{aB}$ & $2,20 \mathrm{aA}$ & $2,00 \mathrm{aA}$ & $2,1 \mathrm{MS}$ \\
\hline FB 200 & $1,76 \mathrm{aC}$ & $1,86 \mathrm{aA}$ & $2,15 \mathrm{bA}$ & $2,20 \mathrm{bB}$ & $1,9 \mathrm{MR}$ \\
\hline GAZ Pl.1 & $2,29 \mathrm{aE}$ & $2,20 \mathrm{aC}$ & $2,30 \mathrm{aB}$ & $2,17 \mathrm{aB}$ & $2,2 \mathrm{MS}$ \\
\hline Gig. Amar Pl.1 & $2,03 \mathrm{aD}$ & $2,35 \mathrm{bC}$ & $2,45 \mathrm{bB}$ & $2,50 \mathrm{bB}$ & $2,3 \mathrm{MS}$ \\
\hline Gig. Amar Pl.2 & $2,22 \mathrm{aE}$ & $2,20 \mathrm{aC}$ & $2,1 \mathrm{aA}$ & $2,15 \mathrm{aB}$ & $2,2 \mathrm{MS}$ \\
\hline Gig. Amar Pl.3 & $1,10 \mathrm{aA}$ & $2,20 \mathrm{bC}$ & $2,50 \mathrm{cB}$ & $2,20 \mathrm{bB}$ & $2,0 \mathrm{MS}$ \\
\hline MAR20\#10 & $2,65 \mathrm{bE}$ & $2,23 \mathrm{aC}$ & $2,15 \mathrm{aA}$ & $2,10 \mathrm{aA}$ & 2,3 MS \\
\hline MAR20\#12 PI.2 & $1,80 \mathrm{aC}$ & $2,59 \mathrm{bC}$ & $2,00 \mathrm{aA}$ & $2,10 \mathrm{aA}$ & $2,1 \mathrm{MS}$ \\
\hline MAR20\#15 & $1,80 \mathrm{aC}$ & $2,13 \mathrm{bB}$ & $2,00 \mathrm{aA}$ & $2,40 \mathrm{bB}$ & $2,2 \mathrm{MS}$ \\
\hline MAR20\#19 & $1,93 \mathrm{aD}$ & $2,16 \mathrm{aB}$ & $2,13 \mathrm{aA}$ & $2,20 \mathrm{aB}$ & $2,1 \mathrm{MS}$ \\
\hline MAR20\#24 PI.1 & $2,20 \mathrm{aE}$ & $2,57 \mathrm{bC}$ & $2,30 \mathrm{aB}$ & $2,15 \mathrm{aB}$ & $2,3 \mathrm{MS}$ \\
\hline MAR20\#24 PI.2 & $1,73 \mathrm{aC}$ & $2,00 \mathrm{bB}$ & $2,00 \mathrm{bA}$ & $2,10 \mathrm{bA}$ & $1,9 \mathrm{MR}$ \\
\hline MAR20\#34 & $1,53 \mathrm{aB}$ & $2,83 \mathrm{CD}$ & $2,10 \mathrm{bA}$ & $2,10 \mathrm{bA}$ & $2,1 \mathrm{MS}$ \\
\hline MAR20\#39 & $2,20 \mathrm{aE}$ & $2,31 \mathrm{aC}$ & $2,23 \mathrm{aA}$ & $2,05 \mathrm{aA}$ & $2,2 \mathrm{MS}$ \\
\hline MAR20\#41 & $2,34 \mathrm{aE}$ & $2,36 \mathrm{aC}$ & $2,15 \mathrm{aA}$ & $2,23 \mathrm{aB}$ & $2,3 \mathrm{MS}$ \\
\hline MAR20\#44 & $2,08 \mathrm{aD}$ & $2,37 \mathrm{bC}$ & $1,95 \mathrm{aA}$ & $2,00 \mathrm{aA}$ & $2,1 \mathrm{MS}$ \\
\hline MAR20\#44 Pl.1 & $1,45 \mathrm{aB}$ & $1,85 \mathrm{bA}$ & $2,20 \mathrm{cA}$ & $2,10 \mathrm{cA}$ & 1,9 MR \\
\hline MAR20\#46 & $1,20 \mathrm{aA}$ & $1,90 \mathrm{bA}$ & $2,15 \mathrm{cA}$ & $1,80 \mathrm{bA}$ & $1,8 \mathrm{MR}$ \\
\hline MAR20\#46 Pl.1 & $1,50 \mathrm{aB}$ & $1,75 \mathrm{bA}$ & $1,98 \mathrm{bA}$ & $1,90 \mathrm{bA}$ & $1,8 \mathrm{MR}$ \\
\hline MAR20\#46 Pl.2 & $1,57 \mathrm{aB}$ & $2,00 \mathrm{bB}$ & $2,20 \mathrm{bA}$ & $2,03 \mathrm{bA}$ & $1,9 \mathrm{MR}$ \\
\hline MSCA & $2,10 \mathrm{aD}$ & $1,83 \mathrm{aA}$ & $1,97 \mathrm{aA}$ & $2,00 \mathrm{aA}$ & 1,9 MR \\
\hline MSCA Pl.1 & $1,20 \mathrm{aE}$ & $2,14 \mathrm{aB}$ & $2,00 \mathrm{aA}$ & $2,10 \mathrm{aA}$ & 1,9 MR \\
\hline MSCA PI.2 & $2,00 \mathrm{aD}$ & $2,27 \mathrm{bC}$ & $2,40 \mathrm{bB}$ & $2,55 \mathrm{bB}$ & $2,3 \mathrm{MS}$ \\
\hline PA 01 & $2,10 \mathrm{aD}$ & $1,97 \mathrm{aB}$ & $2,15 \mathrm{aA}$ & $2,00 \mathrm{aA}$ & $2,1 \mathrm{MS}$ \\
\hline RC 3 & $1,86 \mathrm{aC}$ & $2,00 \mathrm{aB}$ & $2,15 \mathrm{bA}$ & $2,30 \mathrm{bB}$ & $2,1 \mathrm{MS}$ \\
\hline Rosa Claro Pl.1 & $2,71 \mathrm{bE}$ & $2,10 \mathrm{aB}$ & $2,10 \mathrm{aA}$ & $1,90 \mathrm{aA}$ & $2,2 \mathrm{MS}$ \\
\hline Rosa Int PI.1 & $1,80 \mathrm{aC}$ & $2,28 \mathrm{bC}$ & $2,15 \mathrm{bA}$ & $2,03 \mathrm{bA}$ & $2,1 \mathrm{MS}$ \\
\hline Rosa Int PI.2 & $2,25 \mathrm{aE}$ & $2,30 \mathrm{aC}$ & $2,05 \mathrm{aA}$ & $2,20 \mathrm{aB}$ & $2,2 \mathrm{MS}$ \\
\hline Rosa Int Pl.3 & $1,57 \mathrm{aB}$ & $1,80 \mathrm{aA}$ & $2,10 \mathrm{bA}$ & $2,40 \mathrm{cB}$ & $1,9 \mathrm{MR}$ \\
\hline
\end{tabular}




\begin{tabular}{|l|l|l|l|l|l|}
\hline Rubi Gig. Pl.1 & $1,90 \mathrm{aD}$ & $2,38 \mathrm{bC}$ & $2,20 \mathrm{bA}$ & $2,00 \mathrm{aA}$ & $2,1 \mathrm{MS}$ \\
\hline Rubi Gig. Pl.2 & $1,81 \mathrm{aC}$ & $2,32 \mathrm{bC}$ & $2,20 \mathrm{bA}$ & $2,13 \mathrm{bA}$ & $2,1 \mathrm{MS}$ \\
\hline
\end{tabular}

*Médias seguidas pela mesma letra, minúsculas, nas linhas e maiúsculas, nas colunas, não diferem estatisticamente, entre si, pelo teste de Scott Knott ao nível de 5\%.

\section{B - ANTRACNOSE}

Houve diferença estatística da interação progênies x épocas na avaliação de incidência e severidade da doença (Tabela 31).

Nenhuma das progênies teve todos os seus frutos atacados pela doença, no entanto, a progênie que teve $50 \%$ dos seus frutos atacados, sendo esta a máxima, foi de Gig. Amar. Pl.3, mesmo assim, a doença só apareceu na $2^{\mathrm{a}}$ época.

As progênies MAR20\#46 e Rosa Int. Pl.3 só foram apresentar a doença na $3^{\text {a época e as }}$ progênies 20\#34 F2, EC3-0, Gig. Amar. P1.3, MAR20\#10, MAR20\#12 Pl.2, MAR20\#15, MAR20\#39, MAR20\#41, MAR20\#44 Pl.1, MSCA, MSCA Pl.1, MSCA Pl.2 e Rosa Claro Pl.1 foram apresentar na $2^{\mathrm{a}}$ época.

BOUZA (2009), trabalhando com vinte e quatro progênies de maracujazeiro-azedo, verificou que todas as progênies em condições de campo foram consideradas moderadamente suscetíveis para antracnose.

Em condições de campo, SOUSA (2005) avaliou dezessete progênies propagadas sexualmente e classificou-as como resistentes à antracnose nas avaliações de incidência e severidade em frutos.

A antracnose provavelmente é a doença de menor incidência na cultura do maracujazeiro quando observamos o trabalho apresentado, visto que a Tabela 30 apresenta os menores valores de incidência.

Na progênie de Gigante Amarelo Pl.3 houve diferença estatística entre as épocas, no entanto, apenas na $2^{\mathrm{a}}$ época houve maior incidência e em todas as outras épocas apresentou baixa incidência.

Entre a $2^{\mathrm{a}}$ e a $3^{\mathrm{a}}$ época, catorze progênies apresentaram redução da incidência da doença para $0 \%$ de uma época para outra, mostrando que o efeito ambiental não teve influência na multiplicação do patógeno entre as duas épocas (Tabela 31).

Foi observada incidência máxima de 50\% apenas na progênie Gigante Amarelo Pl.3 e de 0\% em várias outras progênies e épocas (Tabela 31).

Verifica-se, em algumas progênies, a incidência da doença em seguida sua redução, depois seu aumento novamente, tal fato pode ser explicado pela influência do ambiente em 
todos os estádios de desenvolvimento do patógeno e da planta hospedeira, nas diversas fases do ciclo das relações patógeno-hospedeiro. Assim, mudanças na temperatura do ambiente podem afetar a incidência e a severidade da doença pela ação direta sobre o metabolismo do patógeno ou pela debilitação fisiológica da planta, predispondo-a à infecção (GHINI, 2011).

No tocante à incidência de antracnose, quinze progênies apresentaram os menores valores de incidência (0,00\%). São elas: 20\#34 F2, EC3-0, Gigante Amar. P1.3, MAR20\#10, MAR20\#12 Pl.2, MAR20\#15, MAR20\#39, MAR20\#41, MAR20\#44 P1.1, MAR20\#46, MSCA, MSCA Pl.1, MSCA Pl.2, Rosa Claro Pl.1 e Rosa Int. Pl.3, na 1ª́poca.

JUNQUEIRA et al. (2003) em experimentos realizados em condições de campo, avaliando-se frutos, sem o uso de agrotóxicos e com inóculo natural observaram que houve diferenças significativas de reação das progênies à antracnose no fruto, não tendo, no entanto, nenhum apresentando resistência completa. A progênie EC3-0 foi classificada por esses autores como moderadamente resistentes e por SOUSA (2009) altamente suscetíveis, e no presente trabalho foi classificada assim como por JUNQUEIRA et al. (2003) como moderadamente resistente, tal fato demonstra que as condições ambientais podem ser bastante diversas, podendo apresentar diferenças substanciais no grau de resistência além da variabilidade do patógeno que apresenta seu patossistema com características peculiares de temperatura mínima, ótima e máxima de desenvolvimento.

VILELA (2013) obteve índice de severidade máxima em MAR20\#46 de 3,69\% diferindo do presente trabalho que apresentou média nas quatro épocas de $1,1 \%$.

As progênies MAR20\#2005 P1.1, 20\#34 F2, EC3-0, FB200, MAR20\#10, MAR20\#34, MAR20\#39, MAR20\#41, Rosa Claro Pl.1 e Rubi Gig. Pl.2 se destacaram em todas as épocas por apresentarem a severidade baixa, não favorecendo o acontecimento da doença em todas as épocas. Essas mesmas progênies mantiveram-se constantes ao longo das quatro épocas.

MIRANDA (2004) avaliou a incidência e severidade de antracnose em quinze progênies de maracujazeiro de propagação sexuada, sem aplicação de agrotóxicos em condições de campo (inóculo natural) em frutos e classificou catorze progênies como moderadamente resistentes e uma (MAR20\#36) como resistente. E no presente trabalho, assim como no citado de acordo com a escala de notas criada por JUNQUEIRA et al., (2003), com modificações, as progênies mantiveram as médias dentro da faixa moderadamente resistente (MR) em sua totalidade.

Tabela 31 - Incidência (\%) de antracnose nas quatro diferentes épocas em quarenta e duas progênies de maracujazeiro-azedo. 


\begin{tabular}{|c|c|c|c|c|c|}
\hline \multicolumn{6}{|c|}{ ANTRACNOSE (INCIDÊNCIA) } \\
\hline PROGÊNIES & 1 & 2 & 3 & 4 & MÉDIA \\
\hline MAR20\#2005 Pl.1 & $6,70 \mathrm{aB}$ & $5,00 \mathrm{aA}$ & $6,70 \mathrm{aB}$ & $5,00 \mathrm{aB}$ & 5,85 \\
\hline MAR20\#2005 PI.2 & $30,70 \mathrm{aD}$ & $13,30 \mathrm{aB}$ & $10,00 \mathrm{aB}$ & $20,00 \mathrm{aD}$ & 18,50 \\
\hline MAR20\#2005 Pl.3 & $13,30 \mathrm{aB}$ & $27,50 \mathrm{aB}$ & $6,70 \mathrm{aA}$ & $15,00 \mathrm{aC}$ & 15,63 \\
\hline MAR20\#2005 Pl.4 & $10,00 \mathrm{aB}$ & $21,80 \mathrm{bB}$ & $5,00 \mathrm{aA}$ & $20,00 \mathrm{bD}$ & 14,20 \\
\hline $20 \# 34$ F2 & $0,00 \mathrm{aA}$ & $5,00 \mathrm{aA}$ & $0,00 \mathrm{aA}$ & $0,00 \mathrm{aA}$ & 1,25 \\
\hline AP 01 & $37,50 \mathrm{bD}$ & $5,00 \mathrm{aA}$ & $15,00 \mathrm{bC}$ & $20,00 \mathrm{bD}$ & 19,38 \\
\hline AR 2 & $20,00 \mathrm{bD}$ & $10,00 \mathrm{bB}$ & $0,00 \mathrm{aA}$ & $0,00 \mathrm{aA}$ & 7,50 \\
\hline EC3-0 & $0,00 \mathrm{aA}$ & $5,00 \mathrm{aA}$ & $3,30 \mathrm{aA}$ & $7,50 \mathrm{aB}$ & 3,95 \\
\hline EC3-0 PI.1 & $30,00 \mathrm{cD}$ & $0,00 \mathrm{aA}$ & $10,00 \mathrm{bB}$ & $30,00 \mathrm{cD}$ & 17,50 \\
\hline ECL 7 & $21,70 \mathrm{bD}$ & $14,70 \mathrm{aB}$ & $6,70 \mathrm{aB}$ & $30,00 \mathrm{bD}$ & 18,28 \\
\hline ECRAM PI.2 & $5,00 \mathrm{aB}$ & $45,00 \mathrm{bC}$ & $0,00 \mathrm{aA}$ & $25,00 \mathrm{bD}$ & 18,75 \\
\hline ECRAM PI.3 & $10,00 \mathrm{bC}$ & $3,30 \mathrm{aA}$ & $10,00 \mathrm{bB}$ & $0,00 \mathrm{aA}$ & 5,83 \\
\hline FB 200 & $6,70 \mathrm{aB}$ & $11,00 \mathrm{aB}$ & $10,00 \mathrm{aB}$ & $15,00 \mathrm{aC}$ & 10,68 \\
\hline GAZ Pl.1 & $14,30 \mathrm{bC}$ & $10,00 \mathrm{bB}$ & $0,00 \mathrm{aA}$ & $20,00 \mathrm{bD}$ & 11,08 \\
\hline Gig. Amar Pl.1 & $8,30 \mathrm{aB}$ & $15,00 \mathrm{bB}$ & $0,00 \mathrm{cA}$ & $10,00 \mathrm{dD}$ & 8,33 \\
\hline Gig. Amar Pl.2 & $3,30 \mathrm{bD}$ & $10,00 \mathrm{aB}$ & $20,00 \mathrm{bC}$ & $5,00 \mathrm{aB}$ & 9,58 \\
\hline Gig. Amar Pl.3 & $0,00 \mathrm{aA}$ & $50,00 \mathrm{cC}$ & $20,00 \mathrm{bC}$ & $30,00 \mathrm{bD}$ & 25,00 \\
\hline MAR20\#10 & $0,00 \mathrm{aA}$ & $3,30 \mathrm{aA}$ & $12,50 \mathrm{bB}$ & $10,00 \mathrm{bB}$ & 6,45 \\
\hline MAR20\#12 PI.2 & $0,00 \mathrm{aA}$ & $31,50 \mathrm{cC}$ & $0,00 \mathrm{aA}$ & $10,00 \mathrm{bB}$ & 10,38 \\
\hline MAR20\#15 & $0,00 \mathrm{aA}$ & $10,00 \mathrm{bB}$ & $0,00 \mathrm{aA}$ & $15,00 \mathrm{bC}$ & 6,25 \\
\hline MAR20\#19 & $13,30 \mathrm{aB}$ & $10,60 \mathrm{aB}$ & $12,50 \mathrm{aB}$ & $20,00 \mathrm{aD}$ & 14,10 \\
\hline MAR20\#24 PI.1 & $16,70 \mathrm{bC}$ & $0,00 \mathrm{aA}$ & $50,00 \mathrm{bB}$ & $5,00 \mathrm{bB}$ & 17,93 \\
\hline MAR20\#24 Pl.2 & $3,70 \mathrm{aB}$ & $20,00 \mathrm{bB}$ & $0,00 \mathrm{aA}$ & $10,00 \mathrm{bC}$ & 8,43 \\
\hline MAR20\#34 & $4,20 \mathrm{aB}$ & $13,30 \mathrm{aB}$ & $10,00 \mathrm{aB}$ & $10,00 \mathrm{aB}$ & 9,38 \\
\hline MAR20\#39 & $0,00 \mathrm{aA}$ & $3,30 \mathrm{aA}$ & $0,00 \mathrm{aA}$ & $15,00 \mathrm{bC}$ & 4,58 \\
\hline MAR20\#41 & $0,00 \mathrm{aA}$ & $5,00 \mathrm{aA}$ & $15,00 \mathrm{bC}$ & $14,10 \mathrm{bC}$ & 8,53 \\
\hline MAR20\#44 & $16,70 \mathrm{aC}$ & $11,10 \mathrm{aA}$ & $25,00 \mathrm{aC}$ & $20,00 \mathrm{aD}$ & 18,20 \\
\hline MAR20\#44 PI.1 & $0,00 \mathrm{aA}$ & $5,00 \mathrm{bA}$ & $3,10 \mathrm{aA}$ & $20,00 \mathrm{aD}$ & 7,03 \\
\hline MAR20\#46 & $0,00 \mathrm{aA}$ & $0,00 \mathrm{aA}$ & $25,00 \mathrm{bC}$ & $10,00 \mathrm{bC}$ & 8,75 \\
\hline MAR20\#46 PI.1 & $25,00 \mathrm{bC}$ & $3,30 \mathrm{aA}$ & $0,00 \mathrm{aA}$ & $5,00 \mathrm{aB}$ & 8,33 \\
\hline MAR20\#46 PI.2 & $13,70 \mathrm{aC}$ & $9,70 \mathrm{aB}$ & $35,00 \mathrm{bC}$ & $5,00 \mathrm{aB}$ & 15,85 \\
\hline MSCA & $0,00 \mathrm{aA}$ & $19,50 \mathrm{bB}$ & $14,00 \mathrm{bB}$ & $0,00 \mathrm{aA}$ & 8,38 \\
\hline MSCA Pl.1 & $0,00 \mathrm{aA}$ & $16,70 \mathrm{bB}$ & $10,00 \mathrm{bB}$ & $15,00 \mathrm{bC}$ & 10,43 \\
\hline MSCA Pl.2 & $0,00 \mathrm{aA}$ & $6,70 \mathrm{bA}$ & $0,00 \mathrm{aA}$ & $30,00 \mathrm{aD}$ & 9,18 \\
\hline PA 01 & $30,00 \mathrm{bD}$ & $4,20 \mathrm{aA}$ & $0,00 \mathrm{aA}$ & $0,00 \mathrm{aA}$ & 8,55 \\
\hline RC 3 & $28,60 \mathrm{bD}$ & $28,60 \mathrm{bC}$ & $0,00 \mathrm{aA}$ & $20,00 \mathrm{bD}$ & 19,30 \\
\hline Rosa Claro Pl.1 & $0,00 \mathrm{aA}$ & $16,70 \mathrm{bB}$ & $10,00 \mathrm{bB}$ & $10,00 \mathrm{bC}$ & 9,18 \\
\hline Rosa Int Pl.1 & $7,50 \mathrm{aB}$ & $5,00 \mathrm{aA}$ & $10,00 \mathrm{aB}$ & $10,00 \mathrm{aB}$ & 8,13 \\
\hline Rosa Int Pl.2 & $20,80 \mathrm{bC}$ & $0,00 \mathrm{aA}$ & $5,00 \mathrm{aB}$ & $16,70 \mathrm{bC}$ & 10,63 \\
\hline Rosa Int PI.3 & $0,00 \mathrm{aAD}$ & $0,00 \mathrm{aA}$ & $10,00 \mathrm{bB}$ & $30,00 \mathrm{cD}$ & 10,00 \\
\hline Rubi Gig. Pl.1 & $20,00 \mathrm{aD}$ & $5,00 \mathrm{aA}$ & $15,00 \mathrm{aC}$ & $10,00 \mathrm{aC}$ & 12,50 \\
\hline Rubi Gig. Pl.2 & $6,70 \mathrm{bB}$ & $10,00 \mathrm{bB}$ & $0,00 \mathrm{aA}$ & $6,70 \mathrm{bB}$ & 5,85 \\
\hline
\end{tabular}

*Médias seguidas pela mesma letra, minúsculas, nas linhas e maiúsculas, nas colunas, não diferem estatisticamente, entre si, pelo teste de Scott Knott ao nível de 5\%. 
Tabela 32 - Severidade de antracnose nas quatro diferentes épocas em quarenta e duas progênies de maracujazeiro-azedo.

\begin{tabular}{|c|c|c|c|c|c|}
\hline \multicolumn{6}{|c|}{ ANTRACNOSE (SEVERIDADE) } \\
\hline PROGÊNIES & 1 & 2 & 3 & 4 & MÉDIA - GR \\
\hline MAR20\#2005 Pl.1 & $1,06 \mathrm{aA}$ & $1,05 \mathrm{aA}$ & $1,05 \mathrm{aA}$ & $1,05 \mathrm{aA}$ & $1,0 \mathrm{MR}$ \\
\hline MAR20\#2005 PI.2 & $1,40 \mathrm{bC}$ & $1,20 \mathrm{aA}$ & $1,10 \mathrm{aA}$ & $1,20 \mathrm{aB}$ & $1,2 \mathrm{MR}$ \\
\hline MAR20\#2005 PI.3 & $1,2 \mathrm{aB}$ & $1,5 \mathrm{bC}$ & $1,1 \mathrm{aA}$ & $1,20 \mathrm{aB}$ & $1,2 \mathrm{MR}$ \\
\hline MAR20\#2005 PI.4 & $1,1 \mathrm{aB}$ & $1,3 \mathrm{bB}$ & $1,00 \mathrm{aA}$ & $1,20 \mathrm{aB}$ & $1,1 \mathrm{MR}$ \\
\hline $20 \# 34$ F2 & $1,00 \mathrm{aA}$ & $1,00 \mathrm{aA}$ & $1,00 \mathrm{aA}$ & $1,00 \mathrm{aA}$ & $1,0 \mathrm{MR}$ \\
\hline AP 01 & $1,00 \mathrm{bC}$ & $1,10 \mathrm{aA}$ & $1,30 \mathrm{aA}$ & $1,40 \mathrm{bC}$ & $1,2 \mathrm{MR}$ \\
\hline AR2 & $1,30 \mathrm{bC}$ & $1,00 \mathrm{aA}$ & $1,00 \mathrm{aA}$ & $1,00 \mathrm{aA}$ & $1,2 \mathrm{MR}$ \\
\hline EC3-0 & $1,00 \mathrm{aA}$ & $1,00 \mathrm{aA}$ & $1,00 \mathrm{aA}$ & $1,10 \mathrm{aA}$ & $1,03 \mathrm{MR}$ \\
\hline EC3-0 Pl.1 & $1,30 \mathrm{bC}$ & $1,00 \mathrm{aA}$ & $1,10 \mathrm{aA}$ & $1,30 \mathrm{bC}$ & $1,18 \mathrm{MR}$ \\
\hline ECL 7 & $1,20 \mathrm{aC}$ & $1,10 \mathrm{aA}$ & $1,10 \mathrm{aA}$ & $1,40 \mathrm{bC}$ & $1,2 \mathrm{MR}$ \\
\hline ECRAM PI.2 & $1,00 \mathrm{aA}$ & $1,60 \mathrm{cC}$ & $1,00 \mathrm{aA}$ & $1,20 \mathrm{bB}$ & $1,2 \mathrm{MR}$ \\
\hline ECRAM PI.3 & $1,10 \mathrm{aB}$ & $1,00 \mathrm{aA}$ & $1,10 \mathrm{aA}$ & $1,00 \mathrm{aA}$ & $1,0 \mathrm{MR}$ \\
\hline FB 200 & $1,00 \mathrm{aA}$ & $1,20 \mathrm{aA}$ & $1,10 \mathrm{aA}$ & $1,10 \mathrm{aA}$ & $1,1 \mathrm{MR}$ \\
\hline GAZ PI.1 & $1,40 \mathrm{cC}$ & $1,10 \mathrm{bA}$ & $1,00 \mathrm{aA}$ & $1,20 \mathrm{bB}$ & $1,2 \mathrm{MR}$ \\
\hline Gig.Amar. Pl.1 & $1,10 \mathrm{aB}$ & $1,20 \mathrm{bA}$ & $1,00 \mathrm{aA}$ & $1,40 \mathrm{cC}$ & $1,2 \mathrm{MR}$ \\
\hline Gig.Amar. Pl.2 & $1,30 \mathrm{bC}$ & $1,10 \mathrm{aA}$ & $1,20 \mathrm{bB}$ & $1,00 \mathrm{aA}$ & $1,1 \mathrm{MR}$ \\
\hline Gig.Amar. Pl.3 & $1,00 \mathrm{aA}$ & $1,50 \mathrm{dC}$ & $1,20 \mathrm{bB}$ & $1,30 \mathrm{cC}$ & $1,2 \mathrm{MR}$ \\
\hline MAR20\#10 & $1,00 \mathrm{aA}$ & $1,00 \mathrm{aA}$ & $1,10 \mathrm{aA}$ & $1,10 \mathrm{aA}$ & $1,0 \mathrm{MR}$ \\
\hline MAR20\#12 PI.2 & $1,00 \mathrm{aA}$ & $1,30 \mathrm{bB}$ & $1,00 \mathrm{aA}$ & $1,20 \mathrm{bB}$ & $1,1 \mathrm{MR}$ \\
\hline MAR20\#15 & $1,00 \mathrm{aA}$ & $1,10 \mathrm{aA}$ & $1,00 \mathrm{aA}$ & $1,20 \mathrm{bB}$ & $1,1 \mathrm{MR}$ \\
\hline MAR20\#19 & $1,10 \mathrm{aB}$ & $1,10 \mathrm{aA}$ & $1,10 \mathrm{aA}$ & $1,20 \mathrm{aB}$ & $1,1 \mathrm{MR}$ \\
\hline MAR20\#24 Pl.1 & $1,20 \mathrm{aB}$ & $1,00 \mathrm{aA}$ & $1,00 \mathrm{aA}$ & $1,00 \mathrm{aA}$ & $1,0 \mathrm{MR}$ \\
\hline MAR20\#24 PI.2 & $1,00 \mathrm{aA}$ & $1,20 \mathrm{bB}$ & $1,00 \mathrm{aA}$ & $1,10 \mathrm{aA}$ & $1,1 \mathrm{MR}$ \\
\hline MAR20\#34 & $1,00 \mathrm{aA}$ & $1,10 \mathrm{aA}$ & $1,10 \mathrm{aA}$ & $1,10 \mathrm{aA}$ & $1,1 \mathrm{MR}$ \\
\hline MAR20\#39 & $1,00 \mathrm{aA}$ & $1,00 \mathrm{aA}$ & $1,00 \mathrm{aA}$ & $1,10 \mathrm{aA}$ & $1,0 \mathrm{MR}$ \\
\hline MAR20\#41 & $1,00 \mathrm{aA}$ & $1,00 \mathrm{aA}$ & $1,10 \mathrm{aA}$ & $1,10 \mathrm{aA}$ & $1,1 \mathrm{MR}$ \\
\hline MAR20\#44 & $1,10 \mathrm{aB}$ & $1,10 \mathrm{aA}$ & $1,20 \mathrm{aB}$ & $1,20 \mathrm{aB}$ & $1,1 \mathrm{MR}$ \\
\hline MAR20\#44 Pl.1 & $1,0 \mathrm{aA}$ & $1,0 \mathrm{aA}$ & $1,0 \mathrm{aA}$ & $1,2 \mathrm{bB}$ & $1,1 \mathrm{MR}$ \\
\hline MAR20\#46 & $1,0 \mathrm{aA}$ & $1,0 \mathrm{aA}$ & $1,2 \mathrm{bB}$ & $1,1 \mathrm{aA}$ & $1,1 \mathrm{MR}$ \\
\hline MAR20\#46 Pl.1 & $1,3 \mathrm{bC}$ & $1,0 \mathrm{aA}$ & $1,0 \mathrm{aA}$ & $1,0 \mathrm{aA}$ & $1,1 \mathrm{MR}$ \\
\hline MAR20\#46 PI.2 & $1,1 \mathrm{aB}$ & $1,1 \mathrm{bA}$ & $1,6 \mathrm{aC}$ & $1,0 \mathrm{aA}$ & $1,2 \mathrm{MR}$ \\
\hline MSCA & $1,0 \mathrm{aA}$ & $1,2 \mathrm{bA}$ & $1,1 \mathrm{bA}$ & $1,0 \mathrm{aA}$ & $1,1 \mathrm{MR}$ \\
\hline MSCA PI.1 & $1,0 \mathrm{aA}$ & $1,3 \mathrm{bB}$ & $1,1 \mathrm{aA}$ & $1,1 \mathrm{aA}$ & $1,1 \mathrm{MR}$ \\
\hline MSCA PI.2 & $1,0 \mathrm{aA}$ & $1,0 \mathrm{bA}$ & $1,0 \mathrm{aA}$ & $1,4 \mathrm{aC}$ & $1,1 \mathrm{MR}$ \\
\hline PA01 & $1,4 \mathrm{aC}$ & $1,0 \mathrm{bA}$ & $1,0 \mathrm{aA}$ & $1,0 \mathrm{aA}$ & $1,1 \mathrm{MR}$ \\
\hline RC3 & $1,3 \mathrm{bC}$ & $1,3 \mathrm{bB}$ & $1,0 \mathrm{aA}$ & $1,2 \mathrm{bB}$ & $1,2 \mathrm{MR}$ \\
\hline Rosa Claro Pl.1 & $1,0 \mathrm{aA}$ & $1,2 \mathrm{aA}$ & $1,1 \mathrm{aA}$ & $1,1 \mathrm{aA}$ & $1,1 \mathrm{MR}$ \\
\hline Rosa Int. Pl.1 & $1,1 \mathrm{aB}$ & $1,0 \mathrm{aA}$ & $1,1 \mathrm{aA}$ & $1,1 \mathrm{aA}$ & $1,1 \mathrm{MR}$ \\
\hline Rosa Int. Pl.2 & $1,3 \mathrm{bC}$ & $1,0 \mathrm{aA}$ & $1,0 \mathrm{aA}$ & $1,2 \mathrm{bA}$ & $1,1 \mathrm{MR}$ \\
\hline Rosa Int. Pl.3 & $1,0 \mathrm{aA}$ & $1,0 \mathrm{bA}$ & $1,1 \mathrm{aA}$ & $1,3 \mathrm{aC}$ & $1,1 \mathrm{MR}$ \\
\hline Rubi Gig. Pl.1 & $1,2 \mathrm{aA}$ & $1,1 \mathrm{aA}$ & $1,0 \mathrm{aA}$ & $1,1 \mathrm{aA}$ & $1,1 \mathrm{MR}$ \\
\hline Rubi Gig. Pl.2 & $1,0 \mathrm{aA}$ & $1,1 \mathrm{aA}$ & $1,0 \mathrm{aA}$ & $1,1 \mathrm{aA}$ & $1,1 \mathrm{MR}$ \\
\hline
\end{tabular}

*Médias seguidas pela mesma letra, minúsculas, nas linhas e maiúsculas, nas colunas, não diferem estatisticamente, entre si, pelo teste de Scott Knott ao nível de 5\%. 


\section{C - VERRUGOSE}

Houve diferença estatística significativa na severidade (número de lesões no fruto) e incidência (percentual de frutos com lesão) à verrugose entre as progênies avaliadas. Na $1^{\text {a }}$ época, as progênies 20\#34 F2, MAR20\#12 Pl.2, MAR20\#15 e RC3 tiveram todos os seus frutos atacados, na $2^{\mathrm{a}}$ época EC3-0 Pl.1 e ECRAM Pl.2, e na $3^{\mathrm{a}}$ época, GAZ Pl.1 e Gigante

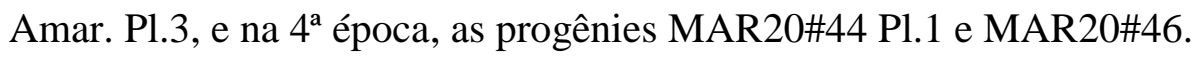

As progênies que tiveram incidência menor ou igual a $50 \%$ foram na $1^{\mathrm{a}}$ época apenas a progênie ECL7; $2^{\mathrm{a}}$ época (Gigante Amar. P1.3 e MAR20\#24 Pl.2), $3^{\mathrm{a}}$ época (AR2, ECRAM PL.3, MAR29\#12P1.2, MAR20\#24 Pl.2, MSCA Pl.2 e Rosa Int.Pl.3) e da $4^{\text {a }}$ época (MAR20\#2005 Pl.2, MAR20\#2005 Pl.4, 20\#34F2, AP01, AR02, EC3-0, EC3-0 Pl.1, ECL 7, FB 200, GAZ Pl.1, Gigante Amar. P1.2, Gigante Amar. Pl.3,MAR20\#10, MAR20\#12 Pl.2, MAR20\#15, MAR20\#24 Pl.1, MAR20\#24 Pl.2, MAR20\#34, MAR20\#41, MAR20\#44, MAR20\#46 Pl.1, MAR20\#46 Pl.2, MSCA, MSCA Pl.1, MSCA Pl.2, PA01, Rosa Claro Pl.1, Rosa Int. Pl.1, Rosa Int. Pl.2, Rosa Int. Pl.3, Rubi Gig. Pl.1 e Rubi Gig. Pl.2), correspondendo a $76 \%$ das progênies com incidência de $50 \%$ ou menos de frutos atacados levando a crer que provavelmente entre as épocas 3 e 4 houve algum fator ambiental que favoreceu a redução do inóculo.

As progênies MAR20\#44 Pl.1 e MAR20\#46 tiveram incidência crescente, chegando na $4^{\mathrm{a}}$ época com $100 \%$ de incidência.

As progênies mantiveram as médias dentro da faixa moderadamente resistente (MR) e moderadamente suscetível (MS) em sua totalidade. Na época 4, as progênies estudadas foram mais tolerantes quando comparadas com as épocas 1, 2 e 3 (Tabela 33).

BOUZA (2009), avaliando catorze progênies em condições de campo, verificou que a progênie RC3 apresentou 84,53\% dos frutos com lesão enquanto que AR02 apresentou a menor média de incidência, 77,36\%. As mesmas progênies no presente trabalho apresentaram as seguintes médias de incidência 76,43\% e 53,33\%, respectivamente, nas quatro épocas.

A menor severidade média foi encontrada em Rubi gig. Pl.1 com 1,4 lesões e a maior na progênie MAR20\#46 com 2,6\% lesões por fruto. Para BOUZA (2009), RC3 foi a progênie que apresentou a maior severidade à cladosporiose. COIMBRA (2010) considerou a progênie RC3 altamente suscetível, VILELA (2013) considerou moderadamente suscetível ao ataque, assim como no presente trabalho. 
Tabela 33 - Incidência (\%) de verrugose nas quatro diferentes épocas em quarenta e duas progênies de maracujazeiro-azedo.

\begin{tabular}{|c|c|c|c|c|c|}
\hline \multicolumn{6}{|c|}{ VERRUGOSE (INCIDÊNCIA) } \\
\hline PROGÊNIES & 1 & 2 & 3 & 4 & MÉDIA \\
\hline MAR20\#2005 PI.1 & $83,33 \mathrm{bC}$ & $74,38 \mathrm{bC}$ & $63,33 \mathrm{aB}$ & $55,00 \mathrm{aB}$ & 69,01 \\
\hline MAR20\#2005 PI.2 & $64,29 \mathrm{bB}$ & $94,44 \mathrm{cD}$ & $53,33 \mathrm{bB}$ & $40,00 \mathrm{aB}$ & 63,02 \\
\hline MAR20\#2005 PI.3 & $88,89 \mathrm{aD}$ & $76,25 \mathrm{aC}$ & $70,00 \mathrm{aC}$ & $75,92 \mathrm{aC}$ & 77,77 \\
\hline MAR20\#2005 PI.4 & $71,67 \mathrm{bB}$ & $58,52 \mathrm{bA}$ & $61,50 \mathrm{bC}$ & $45,00 \mathrm{aB}$ & 59,17 \\
\hline $20 \# 34$ F2 & $100,00 \mathrm{dD}$ & $65,00 \mathrm{bB}$ & $80,00 \mathrm{cC}$ & $40,00 \mathrm{aB}$ & 71,25 \\
\hline AP 01 & $90,00 \mathrm{cD}$ & $81,66 \mathrm{cC}$ & $70,00 \mathrm{bC}$ & $35,00 \mathrm{aB}$ & 69,17 \\
\hline AR 2 & $90,00 \mathrm{cD}$ & $73,33 \mathrm{bC}$ & $30,00 \mathrm{aA}$ & $20,00 \mathrm{aA}$ & 53,33 \\
\hline EC3-0 & $95,00 \mathrm{cD}$ & $83,33 \mathrm{cC}$ & $63,33 \mathrm{bB}$ & $37,50 \mathrm{aB}$ & 69,79 \\
\hline EC3-0 Pl.1 & $80,00 \mathrm{bC}$ & $100,00 \mathrm{cD}$ & $80,00 \mathrm{bC}$ & $20,00 \mathrm{aA}$ & 70,00 \\
\hline ECL 7 & $45,00 \mathrm{bA}$ & $56,43 \mathrm{bA}$ & $60,00 \mathrm{bB}$ & $20,00 \mathrm{aA}$ & 45,36 \\
\hline ECRAM PI.2 & $80,00 \mathrm{aC}$ & $100,00 \mathrm{bD}$ & $90,00 \mathrm{bD}$ & $65,00 \mathrm{aC}$ & 83,75 \\
\hline ECRAM PI.3 & $90,00 \mathrm{cD}$ & $59,26 \mathrm{bA}$ & $30,00 \mathrm{aA}$ & $90,00 \mathrm{cD}$ & 67,32 \\
\hline FB 200 & $90,83 \mathrm{bD}$ & $83,33 \mathrm{bC}$ & $85,00 \mathrm{bD}$ & $10,00 \mathrm{aA}$ & 67,29 \\
\hline GAZ PI.1 & $57,14 \mathrm{aA}$ & $90,00 \mathrm{bD}$ & $100,00 \mathrm{bD}$ & $49,08 \mathrm{aB}$ & 74,06 \\
\hline Gig. Amar. Pl.1 & $95,00 \mathrm{bD}$ & $75,00 \mathrm{aC}$ & $80,00 \mathrm{aC}$ & $90,00 \mathrm{bD}$ & 85,00 \\
\hline Gig. Amar. Pl.2 & $66,66 \mathrm{bB}$ & $70,00 \mathrm{bB}$ & $60,00 \mathrm{bB}$ & $40,00 \mathrm{aB}$ & 59,17 \\
\hline Gig. Amar. Pl.3 & $70,00 \mathrm{bB}$ & $40,00 \mathrm{aA}$ & $100,00 \mathrm{cD}$ & $50,00 \mathrm{aB}$ & 65,00 \\
\hline MAR20\#10 & $83,33 \mathrm{bC}$ & $65,00 \mathrm{bB}$ & $75,00 \mathrm{bC}$ & $28,33 \mathrm{aA}$ & 62,92 \\
\hline MAR20\#12 Pl.2 & $100,00 \mathrm{cD}$ & $85,18 \mathrm{cC}$ & $40,00 \mathrm{bA}$ & $23,33 \mathrm{aA}$ & 62,13 \\
\hline MAR20\#15 & $100,00 \mathrm{cD}$ & $70,00 \mathrm{bB}$ & $80,00 \mathrm{bC}$ & $40,00 \mathrm{aB}$ & 72,50 \\
\hline MAR20\#19 & $73,33 \mathrm{aB}$ & $80,00 \mathrm{aC}$ & $75,00 \mathrm{aC}$ & $60,00 \mathrm{aC}$ & 72,08 \\
\hline MAR20\#24 Pl.1 & $82,22 \mathrm{bC}$ & $71,43 \mathrm{bB}$ & $90,00 \mathrm{bD}$ & $40,00 \mathrm{aB}$ & 70,91 \\
\hline MAR20\#24 Pl.2 & $85,92 \mathrm{cC}$ & $50,00 \mathrm{bA}$ & $50,00 \mathrm{bB}$ & $25,00 \mathrm{aA}$ & 52,73 \\
\hline MAR20\#34 & $77,50 \mathrm{bC}$ & $83,33 \mathrm{bC}$ & $80,00 \mathrm{bC}$ & $50,00 \mathrm{aB}$ & 72,71 \\
\hline MAR20\#39 & $52,86 \mathrm{aA}$ & $73,33 \mathrm{bC}$ & $86,42 \mathrm{bD}$ & $65,00 \mathrm{aC}$ & 69,40 \\
\hline MAR20\#41 & $67,50 \mathrm{bB}$ & $73,33 \mathrm{bC}$ & $80,00 \mathrm{bC}$ & $40,00 \mathrm{aB}$ & 65,21 \\
\hline MAR20\#44 & $75,00 \mathrm{bB}$ & $76,2 \mathrm{bC}$ & $85 \mathrm{bD}$ & $40,00 \mathrm{aB}$ & 69,05 \\
\hline MAR20\#44 Pl.1 & $67,50 \mathrm{aB}$ & $85,00 \mathrm{bC}$ & $87,50 \mathrm{bD}$ & $100,00 \mathrm{bD}$ & 85,00 \\
\hline MAR20\#46 & $90,00 \mathrm{aD}$ & $87,86 \mathrm{aD}$ & $90,00 \mathrm{aD}$ & $100,00 \mathrm{aD}$ & 91,97 \\
\hline MAR20\#46 Pl.1 & $62,50 \mathrm{bB}$ & $80,00 \mathrm{cC}$ & $80,00 \mathrm{cC}$ & $30,00 \mathrm{aA}$ & 63,13 \\
\hline MAR20\#46 Pl.2 & $83,33 \mathrm{bC}$ & $77,08 \mathrm{bC}$ & $85,00 \mathrm{bD}$ & $15,00 \mathrm{aA}$ & 65,10 \\
\hline MSCA & $82,22 \mathrm{cC}$ & $66,67 \mathrm{bB}$ & $90,00 \mathrm{cD}$ & $50,00 \mathrm{aB}$ & 72,22 \\
\hline MSCA PI.1 & $89,63 \mathrm{bD}$ & $83,34 \mathrm{bC}$ & $75,00 \mathrm{bC}$ & $40,00 \mathrm{aB}$ & 71,99 \\
\hline MSCA PI.2 & $95,00 \mathrm{bD}$ & $93,33 \mathrm{bD}$ & $50,00 \mathrm{aB}$ & $45,00 \mathrm{aB}$ & 70,83 \\
\hline PA 01 & $80,00 \mathrm{bC}$ & $68,98 \mathrm{bB}$ & $65,00 \mathrm{bB}$ & $50,00 \mathrm{aB}$ & 66,00 \\
\hline RC 3 & $100,00 \mathrm{bD}$ & $85,71 \mathrm{bC}$ & $60,00 \mathrm{aB}$ & $60,00 \mathrm{aC}$ & 76,43 \\
\hline Rosa Claro Pl.1 & $74,43 \mathrm{bB}$ & $73,33 \mathrm{bC}$ & $60,00 \mathrm{aB}$ & $50,00 \mathrm{aB}$ & 64,44 \\
\hline Rosa Int Pl.1 & $71,67 \mathrm{bB}$ & $52,5 \mathrm{bC}$ & $70,00 \mathrm{cC}$ & $20,00 \mathrm{aA}$ & 53,54 \\
\hline Rosa Int PI.2 & $65,08 \mathrm{bB}$ & $75,00 \mathrm{bC}$ & $70,00 \mathrm{bC}$ & $30,00 \mathrm{aA}$ & 60,02 \\
\hline Rosa Int Pl.3 & $80,00 \mathrm{cC}$ & $67,5 \mathrm{cB}$ & $42,00 \mathrm{bA}$ & $20,00 \mathrm{aA}$ & 52,38 \\
\hline Rubi Gig. Pl.1 & $70,00 \mathrm{bB}$ & $65,00 \mathrm{bB}$ & $75,00 \mathrm{bC}$ & $42,00 \mathrm{aB}$ & 63,00 \\
\hline Rubi Gig. Pl.2 & $78,89 \mathrm{bC}$ & $78,57 \mathrm{bC}$ & $85,00 \mathrm{bD}$ & $30,00 \mathrm{aA}$ & 68,12 \\
\hline
\end{tabular}

*Médias seguidas pela mesma letra, minúsculas, nas linhas e maiúsculas, nas colunas, não diferem estatisticamente, entre si, pelo teste de Scott Knott ao nível de 5\%. 
Tabela 34 - Severidade de verrugose nas quatro diferentes épocas em quarenta e duas progênies de maracujazeiro-azedo.

\begin{tabular}{|c|c|c|c|c|c|}
\hline \multicolumn{6}{|c|}{ VERRUGOSE (SEVERIDADE) } \\
\hline PROGÊNIES & 1 & 2 & 3 & 4 & MÈDIA -GR \\
\hline MAR20\#2005 PI.1 & $2,97 \mathrm{bD}$ & $1,85 \mathrm{aA}$ & $1,90 \mathrm{aB}$ & $1,75 \mathrm{aB}$ & $2,1 \mathrm{MS}$ \\
\hline MAR20\#2005 PI.2 & $2,08 \mathrm{bA}$ & $2,61 \mathrm{cC}$ & $1,63 \mathrm{aA}$ & $1,50 \mathrm{aA}$ & $1,9 \mathrm{MR}$ \\
\hline MAR20\#2005 PI.3 & $2,69 \mathrm{bC}$ & $2,16 \mathrm{aB}$ & $2,03 \mathrm{aB}$ & $2,20 \mathrm{aC}$ & $2,3 \mathrm{MS}$ \\
\hline MAR20\#2005 Pl.4 & $1,98 \mathrm{bA}$ & $1,66 \mathrm{aA}$ & $1,95 \mathrm{bB}$ & $1,60 \mathrm{aB}$ & $1,8 \mathrm{MR}$ \\
\hline $20 \# 34$ F2 & $2,24 \mathrm{cB}$ & $1,80 \mathrm{bA}$ & $2,50 \mathrm{cD}$ & $1,40 \mathrm{aA}$ & $1,9 \mathrm{MR}$ \\
\hline AP 01 & $2,95 \mathrm{cD}$ & $2,12 \mathrm{bB}$ & $1,80 \mathrm{bB}$ & $1,85 \mathrm{aA}$ & $2,2 \mathrm{MS}$ \\
\hline AR 2 & $2,30 \mathrm{cB}$ & $1,83 \mathrm{bA}$ & $1,60 \mathrm{bA}$ & $1,30 \mathrm{aA}$ & $1,8 \mathrm{MR}$ \\
\hline EC3-0 & $2,55 \mathrm{cC}$ & $2,13 \mathrm{bB}$ & $1,97 \mathrm{bB}$ & $1,40 \mathrm{aA}$ & 2,0 MS \\
\hline EC3-0 PI.1 & $2,70 \mathrm{cC}$ & $2,50 \mathrm{cC}$ & $1,80 \mathrm{bB}$ & $1,30 \mathrm{aA}$ & $2,1 \mathrm{MS}$ \\
\hline ECL 7 & $1,83 \mathrm{bA}$ & $1,74 \mathrm{bA}$ & $1,80 \mathrm{bB}$ & $1,20 \mathrm{aA}$ & $1,6 \mathrm{MR}$ \\
\hline ECRAM PI.2 & $2,20 \mathrm{bB}$ & $2,90 \mathrm{cC}$ & $2,70 \mathrm{cD}$ & $1,75 \mathrm{aB}$ & $2,4 \mathrm{MS}$ \\
\hline ECRAM PI.3 & $3,10 \mathrm{dD}$ & $1,69 \mathrm{bA}$ & $1,30 \mathrm{aA}$ & $2,70 \mathrm{cD}$ & $2,2 \mathrm{MS}$ \\
\hline FB 200 & $2,82 \mathrm{cC}$ & $2,20 \mathrm{bB}$ & $2,25 \mathrm{bC}$ & $1,10 \mathrm{aA}$ & $2,1 \mathrm{MS}$ \\
\hline GAZ PI.1 & $1,86 \mathrm{aA}$ & $2,10 \mathrm{aB}$ & $2,50 \mathrm{bD}$ & $1,90 \mathrm{aB}$ & $2,1 \mathrm{MS}$ \\
\hline Gig. Amar Pl.1 & $2,26 \mathrm{bB}$ & $2,05 \mathrm{aB}$ & $1,85 \mathrm{aB}$ & $2,60 \mathrm{bD}$ & 2,2 MS \\
\hline Gig. Amar Pl.2 & $1,78 \mathrm{aA}$ & $1,80 \mathrm{aA}$ & $2,10 \mathrm{bB}$ & $1,50 \mathrm{aA}$ & $1,8 \mathrm{MR}$ \\
\hline Gig. Amar Pl.3 & $3,10 \mathrm{cD}$ & $1,60 \mathrm{aA}$ & $2,50 \mathrm{bD}$ & $1,60 \mathrm{aB}$ & $2,2 \mathrm{MS}$ \\
\hline Mar 20\#10 & $2,28 \mathrm{cB}$ & $1,87 \mathrm{bA}$ & $1,93 \mathrm{bB}$ & $1,30 \mathrm{aA}$ & $1,8 \mathrm{MR}$ \\
\hline MAR20\#12 PI.2 & $2,40 \mathrm{bB}$ & $2,30 \mathrm{bB}$ & $1,40 \mathrm{aA}$ & $1,30 \mathrm{aA}$ & $1,8 \mathrm{MR}$ \\
\hline MAR20\#15 & $2,60 \mathrm{bC}$ & $2,13 \mathrm{bB}$ & $2,35 \mathrm{bC}$ & $1,40 \mathrm{aA}$ & $2,1 \mathrm{MS}$ \\
\hline MAR20\#19 & $2,22 \mathrm{aB}$ & $2,18 \mathrm{aB}$ & $2,18 \mathrm{aC}$ & $1,85 \mathrm{aB}$ & $2,1 \mathrm{MS}$ \\
\hline MAR20\#24 PI.1 & $2,35 \mathrm{cB}$ & $2,00 \mathrm{bA}$ & $2,65 \mathrm{cD}$ & $1,50 \mathrm{aA}$ & $2,1 \mathrm{MS}$ \\
\hline MAR20\#24 PI.2 & $2,55 \mathrm{cC}$ & $1,60 \mathrm{bA}$ & $1,70 \mathrm{bA}$ & $1,25 \mathrm{aA}$ & $1,8 \mathrm{MS}$ \\
\hline MAR20\#34 & $2,58 \mathrm{bC}$ & $2,28 \mathrm{bB}$ & $2,40 \mathrm{bC}$ & $1,85 \mathrm{aB}$ & 2,3 MS \\
\hline MAR20\#39 & $1,87 \mathrm{aA}$ & $2,30 \mathrm{bB}$ & $2,47 \mathrm{bD}$ & $2,25 \mathrm{bC}$ & $2,2 \mathrm{MS}$ \\
\hline MAR20\#41 & $2,45 \mathrm{cB}$ & $1,94 \mathrm{bA}$ & $2,05 \mathrm{bB}$ & $1,74 \mathrm{aA}$ & $2,0 \mathrm{MS}$ \\
\hline MAR20\#44 & $1,92 \mathrm{bA}$ & $2,14 \mathrm{bB}$ & $2,55 \mathrm{cD}$ & $1,40 \mathrm{aA}$ & $2,0 \mathrm{MS}$ \\
\hline MAR20\#44 PI.1 & $2,38 \mathrm{aB}$ & $2,20 \mathrm{aB}$ & $2,32 \mathrm{aC}$ & $2,50 \mathrm{aD}$ & 2,3 MS \\
\hline MAR20\#46 & $3,20 \mathrm{bD}$ & $2,25 \mathrm{aB}$ & $2,50 \mathrm{aD}$ & $2,30 \mathrm{aC}$ & $2,6 \mathrm{MS}$ \\
\hline MAR20\#46 PI.1 & $2,13 \mathrm{bB}$ & $2,2 \mathrm{bB}$ & $2,23 \mathrm{bC}$ & $1,30 \mathrm{aA}$ & $1,9 \mathrm{MR}$ \\
\hline MAR20\#46 PI.2 & $2,31 \mathrm{bB}$ & $2,02 \mathrm{bA}$ & $2,25 \mathrm{bC}$ & $1,15 \mathrm{aA}$ & 1,9 MR \\
\hline MSCA & $2,02 \mathrm{bA}$ & $2,00 \mathrm{bA}$ & $2,70 \mathrm{cD}$ & $1,50 \mathrm{aA}$ & 2,1 MS \\
\hline MSCA Pl.1 & $2,45 \mathrm{cB}$ & $2,14 \mathrm{bB}$ & $2,00 \mathrm{bB}$ & $1,48 \mathrm{aA}$ & $2,0 \mathrm{MS}$ \\
\hline MSCA PI.2 & $3,06 \mathrm{cD}$ & $2,28 \mathrm{bB}$ & $1,90 \mathrm{aB}$ & $1,55 \mathrm{aB}$ & $2,2 \mathrm{MS}$ \\
\hline PA 01 & $2,30 \mathrm{bB}$ & $1,81 \mathrm{aA}$ & $1,85 \mathrm{aB}$ & $1,80 \mathrm{aB}$ & $1,9 \mathrm{MR}$ \\
\hline RC 3 & $3,43 \mathrm{cD}$ & $2,29 \mathrm{bB}$ & $1,75 \mathrm{aB}$ & $1,80 \mathrm{aB}$ & $2,3 \mathrm{MS}$ \\
\hline Rosa Claro PI.1 & $2,71 \mathrm{bC}$ & $1,77 \mathrm{aA}$ & $1,73 \mathrm{aB}$ & $1,60 \mathrm{aB}$ & $1,9 \mathrm{MR}$ \\
\hline Rosa Int Pl.1 & $2,02 \mathrm{bA}$ & $1,75 \mathrm{bA}$ & $1,90 \mathrm{bB}$ & $1,20 \mathrm{aA}$ & $1,7 \mathrm{MR}$ \\
\hline Rosa Int Pl. 2 & $1,89 \mathrm{bA}$ & $1,95 \mathrm{bA}$ & $1,90 \mathrm{bB}$ & $1,30 \mathrm{aA}$ & $1,8 \mathrm{MR}$ \\
\hline Rosa Int Pl.3 & $2,40 \mathrm{bB}$ & $2,06 \mathrm{bB}$ & $1,50 \mathrm{aA}$ & $1,20 \mathrm{aA}$ & $1,8 \mathrm{MR}$ \\
\hline Rubi Gig. Pl.1 & $1,80 \mathrm{bA}$ & $2,00 \mathrm{bA}$ & $2,00 \mathrm{bB}$ & $1,40 \mathrm{aA}$ & $1,4 \mathrm{MR}$ \\
\hline Rubi Gig. Pl.2 & $2,89 \mathrm{cD}$ & $2,25 \mathrm{bB}$ & $2,55 \mathrm{bD}$ & $1,33 \mathrm{aA}$ & 2,3 MS \\
\hline
\end{tabular}

*Médias seguidas pela mesma letra, minúsculas, nas linhas e maiúsculas, nas colunas, não diferem estatisticamente, entre si, pelo teste de Scott Knott ao nível de 5\%. 
Houve diferença significativa para a área abaixo da curva de progresso para as doenças septoriose, antracnose e verrugose.

O cálculo da área abaixo da curva de progresso da doença é realizado para análise de severidade da doença.

Para septoria, a progênie MAR20\#46 $(79,50)$ apresentou a menor área abaixo da curva de progresso da doença diferindo estatisticamente da progênie MAR20\#34 (104,11) que apresentou a maior área abaixo da curva de progresso da doença. Para antracnose as progênies 20\#34 F2 e AR2 $(45,75)$ apresentaram valores semelhantes de menor taxa de progresso diferindo estatisticamente da progênie MAR20\#2005 Pl.3 $(56,27)$ que apresentou a maior taxa de progresso e a progênie ECL7 $(75,75)$ com menor taxa de progresso. A progênie ECRAM Pl.2 teve a maior taxa de progresso da doença $(113,63)$ para verrugose como mostra a Tabela 35 .

Tabela 35 - Efeito da septoriose, antracnose e verrugose em progênies de maracujazeiroazedo a partir das médias da área abaixo da curva de progresso da doença (AACPD) em condições de campo.

\begin{tabular}{|c|c|c|c|}
\hline \multicolumn{5}{|c|}{ AACPD-SEVERIDADE } \\
\hline PROGENIES & SEPTORIOSE & ANTRACNOSE & VERRUGOSE \\
\hline MAR20\#2005 PI.1 & $96,08 \mathrm{c}$ & $47,49 \mathrm{a}$ & $91,54 \mathrm{~b}$ \\
\hline MAR20\#2005 PI.2 & $91,18 \mathrm{~b}$ & $53,59 \mathrm{~b}$ & $91,37 \mathrm{~b}$ \\
\hline MAR20\#2005 PI.3 & $90,15 \mathrm{~b}$ & $56,27 \mathrm{~b}$ & $99,58 \mathrm{c}$ \\
\hline MAR20\#2005 PI.4 & $93,50 \mathrm{~b}$ & $52,63 \mathrm{~b}$ & $81,02 \mathrm{a}$ \\
\hline 20\#34 F2 & $86,53 \mathrm{a}$ & $45,75 \mathrm{a}$ & $91,76 \mathrm{~b}$ \\
\hline AP 01 & $87,92 \mathrm{~b}$ & $53,08 \mathrm{~b}$ & $91,01 \mathrm{~b}$ \\
\hline AR 2 & $89,00 \mathrm{~b}$ & $45,75 \mathrm{a}$ & $81,30 \mathrm{a}$ \\
\hline EC3-0 & $91,89 \mathrm{~b}$ & $49,24 \mathrm{a}$ & $91,12 \mathrm{~b}$ \\
\hline EC3-0 PI.1 & $96,00 \mathrm{c}$ & $52,63 \mathrm{~b}$ & $94,50 \mathrm{c}$ \\
\hline ECL 7 & $95,45 \mathrm{c}$ & $53,50 \mathrm{~b}$ & $75,75 \mathrm{a}$ \\
\hline ECRAM PI.2 & $93,75 \mathrm{~b}$ & $54,38 \mathrm{~b}$ & $113,63 \mathrm{e}$ \\
\hline ECRAM PI.3 & $91,54 \mathrm{~b}$ & $47,23 \mathrm{a}$ & $88,39 \mathrm{~b}$ \\
\hline FB 200 & $91,60 \mathrm{~b}$ & $53,20 \mathrm{~b}$ & $96,08 \mathrm{c}$ \\
\hline GAZ PI.1 & $102,68 \mathrm{~d}$ & $48,90 \mathrm{a}$ & $96,45 \mathrm{c}$ \\
\hline Gig. Amar Pl.1 & $112,88 \mathrm{~d}$ & $54,98 \mathrm{~b}$ & $94,97 \mathrm{c}$ \\
\hline Gig. Amar Pl.2 & $92,93 \mathrm{~b}$ & $49,50 \mathrm{a}$ & $83,10 \mathrm{a}$ \\
\hline Gig. Amar Pl.3 & $89,25 \mathrm{~b}$ & $56,25 \mathrm{~b}$ & $96,75 \mathrm{c}$ \\
\hline MAR20\#10 & $94,52 \mathrm{c}$ & $48,62 \mathrm{a}$ & $83,74 \mathrm{a}$ \\
\hline MAR20\#12 PI. 2 & $86,34 \mathrm{a}$ & $50,34 \mathrm{a}$ & $83,25 \mathrm{a}$ \\
\hline MAR20\#15 & $96,11 \mathrm{c}$ & $50,49 \mathrm{a}$ & $97,24 \mathrm{c}$ \\
\hline MAR20\#19 & $101,72 \mathrm{~d}$ & $51,90 \mathrm{~b}$ & $95,85 \mathrm{c}$ \\
\hline MAR20\#24 Pl.1 & $99,77 \mathrm{c}$ & $46,78 \mathrm{a}$ & $98,64 \mathrm{c}$ \\
\hline MAR20\#24 PI.2 & $81,36 \mathrm{a}$ & $48,68 \mathrm{a}$ & $78,00 \mathrm{a}$ \\
\hline
\end{tabular}




\begin{tabular}{|c|c|c|c|}
\hline MAR20\#34 & $104,11 \mathrm{~d}$ & $49,37 \mathrm{a}$ & $103,36 \mathrm{~d}$ \\
\hline MAR20\#39 & $104,03 \mathrm{~d}$ & $47,49 \mathrm{a}$ & $102,41 \mathrm{~d}$ \\
\hline MAR20\#41 & $99,24 \mathrm{c}$ & $50,83 \mathrm{a}$ & $89,18 \mathrm{~b}$ \\
\hline MAR20\#44 & $96,08 \mathrm{c}$ & $52,58 \mathrm{~b}$ & $95,27 \mathrm{c}$ \\
\hline MAR20\#44 Pl.1 & $85,78 \mathrm{a}$ & $48,84 \mathrm{a}$ & $104,36 \mathrm{~d}$ \\
\hline MAR20\#46 & $79,50 \mathrm{a}$ & $52,50 \mathrm{~b}$ & $112,50 \mathrm{~d}$ \\
\hline MAR20\#46 Pl.1 & $81,26 \mathrm{a}$ & $47,03 \mathrm{a}$ & $92,17 \mathrm{~b}$ \\
\hline MAR20\#46 Pl.2 & $88,65 \mathrm{~b}$ & $55,49 \mathrm{~b}$ & $90,02 \mathrm{~b}$ \\
\hline MSCA & $82,99 \mathrm{a}$ & $47,97 \mathrm{a}$ & $96,92 \mathrm{c}$ \\
\hline MSCA PI.1 & $96,73 \mathrm{c}$ & $51,28 \mathrm{~b}$ & $91,48 \mathrm{~b}$ \\
\hline MSCA PI.2 & $96,73 \mathrm{c}$ & $54,51 \mathrm{~b}$ & $97,33 \mathrm{c}$ \\
\hline PA 01 & $91,41 \mathrm{~b}$ & $47,49 \mathrm{a}$ & $85,59 \mathrm{a}$ \\
\hline RC 3 & $89,25 \mathrm{~b}$ & $50,18 \mathrm{a}$ & $99,83 \mathrm{c}$ \\
\hline Rosa Claro PI.1 & $98,44 \mathrm{c}$ & $50,00 \mathrm{a}$ & $84,83 \mathrm{a}$ \\
\hline Rosa Int PI.1 & $92,21 \mathrm{~b}$ & $50,56 \mathrm{a}$ & $78,88 \mathrm{a}$ \\
\hline Rosa Int PI.2 & $95,43 \mathrm{c}$ & $48,26 \mathrm{a}$ & $81,69 \mathrm{a}$ \\
\hline Rosa Int PI.3 & $88,50 \mathrm{~b}$ & $52,50 \mathrm{~b}$ & $80,42 \mathrm{a}$ \\
\hline Rubi Gig. Pl.1 & $100,84 \mathrm{~d}$ & $50,38 \mathrm{a}$ & $84,00 \mathrm{a}$ \\
\hline Rubi Gig. Pl.2 & $95,72 \mathrm{c}$ & $46,50 \mathrm{a}$ & $103,69 \mathrm{~d}$ \\
\hline
\end{tabular}

*Médias seguidas pela mesma letra, minúsculas, nas linhas e maiúsculas, nas colunas, não diferem estatisticamente, entre si, pelo teste de Scott Knott ao nível de 5\%.

Para o presente trabalho é observado (Tabela 36) que os valores de incidência e severidade para a estimativa de herdabilidade e razão $\mathrm{CVg} / \mathrm{CVe}$ foram altos nas três doenças (septoriose, antracnose e verrugose). Esses valores revelam que a variação genética foi maior que ambiental para esses parâmetros e tão logo, alta variabilidade genética. Indicando que a utilização de métodos simples de seleção, como seleção massal, podem ser usados no programa de melhoramento genético de maracujazeiro-azedo com fins de diminuir a incidência e severidade das doenças mencionadas.

VILELA (2013) em seu estudo de herdabilidade, em sentido amplo, para severidade e incidência de septoriose, antracnose e verrugose, observou a maior herdabilidade e relação $\mathrm{CVg} / \mathrm{CVe}$ para incidência de septoriose com os valores $72,63 \%$ e 0,81 , respectivamente, sugerindo que a utilização de métodos simples de seleção massal pode ser usado com o objetivo de diminuir a incidência de septoriose. 
Tabela 36 - Estimativas de herdabilidade sentido amplo $\left(\right.$ ha $\left.^{2}\right)$, coeficiente de variação genético $(\mathrm{CVg})$ e razão entre coeficiente e variação genético e ambiental $(\mathrm{CVg} / \mathrm{CVe})$, utilizando-se dados de quarenta e duas progênies de maracujazeiro-azedo.

\begin{tabular}{|c|c|c|}
\hline Parâmetros Genéticos (Septoria) & INCIDÊNCIA & SEVERIDADE \\
\hline ha $^{\mathbf{2}}$ (média família) & $86,37 \%$ & $78,04 \%$ \\
\hline Cvg & $7,06 \%$ & $6,07 \%$ \\
\hline CVg/Cve & 1,26 & 0,94 \\
\hline Parâmetros Genéticos \\
(Antracnose) & INCIDÊNCIA & SEVERIDADE \\
\hline ha $^{\mathbf{2}}$ (média família) & $82,38 \%$ & $74,64 \%$ \\
\hline Cvg & $42,30 \%$ & $4,95 \%$ \\
\hline CVg/CVe & 1,08 & 0,86 \\
\hline Parâmetros Genéticos (Verrugose) & INCIDÊNCIA & SEVERIDADE \\
\hline ha $^{\mathbf{2}}$ (média família) & $88,70 \%$ & $88,81 \%$ \\
\hline Cvg & $12,99 \%$ & $10,08 \%$ \\
\hline CVg/CVe & 1,40 & 1,41 \\
\hline
\end{tabular}

Incidência: porcentagem (frequência) de plantas doentes em uma amostra ou população (Amorim, 1995).

Severidade: porcentagem da área ou volume de tecido da planta coberto por sintomas é a variável mais utilizada para quantificar doenças foliares (BERGAMIN FILHO \& AMORIM, 1996).

AACPD: Área Abaixo da Curva do Progresso da Doença. 


\section{4 - CONCLUSÕES}

\section{Septoria}

A maioria das progênies teve todos os seus frutos atacados em pelo menos uma das épocas para essa doença.

As progênies que apresentaram baixa incidência tiveram seus frutos atacados entre $10 \mathrm{e}$ $15 \%$ de lesões nos frutos.

Das progênies estudadas, $76 \%$ foram consideradas moderadamente suscetíveis e $24 \%$ moderadamente resistentes.

Antracnose

A antracnose é a doença de menor incidência na cultura do maracujazeiro.

Nenhuma das progênies teve todos os seus frutos atacados pela doença.

$\mathrm{Na} 1^{\mathrm{a}}$ época, quinze progênies não apresentaram a doença.

As progênies foram classificadas como moderadamente resistente (MR) em sua totalidade.

\section{Verrugose}

Algumas progênies tiveram todos os seus frutos atacados em pelo menos uma das épocas estudadas.

As progênies foram classificadas como moderadamente resistentes (MR) e moderadamente suscetíveis (MS) em sua totalidade.

Houve diferença significativa para a área abaixo da curva de progresso para as doenças septoriose, antracnose e verrugose.

Para septoria $(79,50)$ - $(104,11)$, antracnose $(45,75)-(56,27)$ e verrugose $(75,75)$ $(113,63)$, a menor e maior área abaixo da curva de progresso da doença, respectivamente.

Foi verificada alta variabilidade genética entre as progênies avaliadas nas três doenças consideradas. 


\section{REFERÊNCIAS BIBLIOGRÁFICAS}

BOUZA, R.B. Reação em progênies de maracujá-azedo à antracnose, septoriose, cladosporiose e bacteriose em condições de campo e casa de vegetação. Brasília: Universidade de Brasília, 2009. p.160. Dissertação de Mestrado em Fitopatologia.

COIMBRA, K. G.; Desempenho agronômico de progênies de maracujazeiro azedo no Distrito Federal. Brasília: Faculdade de Agronomia e Medicina Veterinária, Universidade de Brasília,2010. p.125. Dissertação de Mestrado

CRUZ, C. D. Programa Genes: aplicativo computacional em genética e estatística. Viçosa: Editora UFV, 1997. p.442.

FALEIRO, F.G.; JUNQUEIRA, N.T.V.; BRAGA, M.F. Germoplasma e melhoramento genético do germoplasma - desafio da pesquisa. In: FALEIRO, F.G.; JUNQUEIRA, N.T.V.; BRAGA, M.F. (Ed.) Maracujá germoplasma e melhoramento genético. Brasília, DF: Embrapa Cerrados, 2005. p. 187-210.

FERREIRA, G. Propagação do maracujazeiro. Informe Agropecuário. Belo Horizonte, MG.: v. 21, n. 206, p. 18-24. 2000.

FISCHER, I.H.; KIMATI, H. \& REZENDE, J.A.M. Doenças do Maracujazeiro. In: KIMATI, H.; AMORIM, L.; REZENDE, J.A.M.; BERGAMIN FILHO, A.; CAMARGO, L.E.A. (Ed.) Manual de Fitopatologia. 2005. v2. 4.ed. São Paulo: Agronômica Ceresp. 467474.

GHINI, R. Impactos das mudanças climáticas sobre doenças de importantes culturas no Brasil. Edit. RAQUEL GHINI, EMÍLIA HAMADA, WAGNER BETTIOL. Jaguariúna: Embrapa Meio Ambiente, 356 p. ISBN 978-85-85771-51-5 1. Mudança climática. 2. Doença de planta. I. Hamada, Emília. II. Bettiol, Wagner. III. Título. 2011.

IBGE - INSTITUTO BRASILEIRO DE GEOGRARIA E ESTATÍSTICA. Maracujá: área plantada e quantidade produzida. Brasília: IBGE, 2011. (Produção Agrícola Municipal em 2009). Disponível em: http://www.sidra.ibge.gov.br/bda/tabela/protabl. Acesso em: fevereiro de 2013.

JUNQUEIRA, N.T.V.; BRAGA, M.F.; FALEIRO, F.G.; PEIXOTO, J.R.; BERNATTI, L.C. Potencial de espécies silvestres de maracujazeiro como fonte de resistência à doenças. In: 
FALEIRO, F.G.; JUNQUEIRA, N.T.V.; BRAGA, M.F. (Ed.) Maracujá germoplasma e melhoramento genético. Brasília, DF: Embrapa Cerrados,2005. p. 80-108.

. ANJOS, J.R.N.; SILVA, A.P.O.; CHAVES, R.C.; GOMES, A.C. Reação às doenças

e produtividade de onze cultivares de maracujá-azedo cultivado sem agrotóxicos. Pesquisa Agropecuária Brasileira. v. 38, n. 8, p. 1005-1010, 2003.

ANJOS, J.R.N.; SHARMA, R.D.; SANZONWICZ, C.; ANDRADE, L.R.M.

Doenças do Maracujazeiro. In: Encontro de Fitopatologia, 3.,Viçosa, 1999. Doenças de fruteiras tropicais: palestras. Anais... Viçosa: UFV, 1999. p. 83-115.

LIMA, A.A.; BORGES, A.L.; Clima e solo. In: LIMA, A.A. (Ed.) Frutas do Brasil: Maracujá, produção e aspectos técnicos. Brasília: EMBRAPA, Informação Tecnológica, 2002. p.104.

MELO, K.T. Comportamento de seis cultivares de maracujazeiro azedo (Passiflora edulis Sims e Passiflora edulis Sims f. flavicarpa Deg.) em Vargem Bonita no Distrito Federal. Brasília: Faculdade de Agronomia e Medicina Veterinária, Universidade de Brasília, 1999. f. 99. Dissertação de Mestrado em Ciências Agrárias.

MELETTI, L.M.M.; SOARES-SCOTT, M.D.; BERNACCI, L.C.; PASSOS, I.R.S. Melhoramento genético do maracujá: passado e futuro. In: Faleiro, F.G.; Junqueira, N.T.V.; Braga, M.F. (Eds.) Maracujá: germoplasma e melhoramento genético. Planaltina,DF: Embrapa Cerrados,2005. p. 55-78.

MIRANDA, H.A. Incidência e severidade de Xanthomonas axonopodis pv. passiflorae, Colletotrichum gloeosporioides, Septoria passiflorae, Cladosporium herbarum e Passion Woodiness fruit virus em genótipos de maracujazeiro azedo cultivados no Distrito Federal. Brasília: Faculdade de Agronomia e Medicina Veterinária, Universidade de Brasília, 2004. f.87. Dissertação de Mestrado em Ciências Agrárias.

RUGGIERO, C.; SÃO JOSE, A. R.; VOLPE C.A.; OLIVEIRA, J.C.; DURIGAN, J.F.; BAUMGARTNER, J.G.; SILVA, J.R.; MAKAMURA, K.I.; FERREIRA, M.E., KAVATI, R.; PEREIRA V.P. Maracujá para exportação: aspectos técnicos da produção. MAARA/ SDR- FRUPEX. Brasilia: Embrapa-SPI,1996 . Publicações Técnicas Frupex, n. 19. p.64.

SANTOS FILHO, H.P. e JUNQUEIRA, N.T. Maracujá: Fitossanidade. Brasília: Embrapa Informação Tecnológica,2006. Série Frutas do Brasil, 32. p.86. 
SOUSA, M.A.F. Produtividade e reação de progênies de maracujazeiro azedo a doenças em campo e casa de vegetação Brasília:. Universidade de Brasília, 2009 p.248. Tese de Doutorado em Fitopatologia.

Avaliação da produtividade, incidência, e severidade de doenças em frutos de 17 genótipos de maracujazeiro amarelo, cultivados no Distrito Federal. Brasília: Faculdade de Agronomia e Medicina Veterinária, Universidade de Brasília, 2005. p.120. Dissertação de Mestrado em Ciências Agrárias

VILELA, M.S. Avaliação de progênies de maracujazeiro azedo quanto ao desempenho agronômico, resistência a doenças e diversidade genética. Brasília: Faculdade de Agronomia e Medicina Veterinária, Universidade de Brasília, 2013. p.181. Tese de Doutorado. 


\section{CAPITULO 5}

RESISTÊNCIA DE PROGÊNIES DE MARACUJAZEIRO-AZEDO À VIROSE E À BACTERIOSE, EM CONDIÇÕES DE CAMPO 


\section{RESUMO}

O maracujazeiro representa uma importante frutífera para o Brasil e tem grande influência no mercado brasileiro. Entretanto, a expansão da cultura tem enfrentado problemas como a escassez de bons materiais e o manejo inadequado, que restringem o aumento da produção ao ocasionarem baixo rendimento e qualidade dos frutos. É perceptível que há alta suscetibilidade das cultivares atuais às principais doenças como o vírus do endurecimento dos frutos (CABMV - Cowpea aphid-borne mosaic vírus) e a bacteriose (Xanthomonas axonopodis pv. passiflorae). Essas doenças causam manchas foliares podendo induzir desfolha e até mesmo causar morte de ramos. Por isso, o desenvolvimento de cultivares resistentes a doenças é muito importante. Nesse sentido, o presente trabalho teve como objetivo avaliar a reação de quarenta e oito progênies (as mesmas do capítulo 3) de maracujazeiro-azedo à bacteriose e à virose do endurecimento dos frutos, em condições de campo, no Distrito Federal. O delineamento experimental utilizado foi o de blocos casualizados, com cinco plantas por parcela e quatro repetições. Os frutos foram colhidos aleatoriamente para avaliação visual do sintoma das doenças que se deve à percepção e à quantificação de lesões na superfície do fruto utilizando a margem de representação de dez frutos por parcela para bacteriose e já para virose foram coletadas vinte folhas, na extremidade superior dos ramos (dez folhas em cada lado da parcela). Para fazer as avaliações foi usada a escala diagramática para bacteriose e escala de notas para virose. De acordo com a tabela de notas tem-se que: quanto à virose, quarenta e cinco progênies foram classificadas como (MS) e três progênies (S), e quanto à bacteriose, trinta e uma progênies foram classificadas como (MS) e onze progênies (MR). Para vírus, o coeficiente de herdabilidade foi baixo, indicando baixa variabilidade genética para esse caráter, diferente da bacteriose que apresentou valores altos de herdabilidade e coeficiente de variação genética e ambiental, indicando alta variabilidade genética.

Palavras-chave: xanthomonas axonopodis pv. passiflorae, melhoramento genético, virose do endurecimento dos frutos. 


\begin{abstract}
The passion fruit is important to Brazil and has great influence in the Brazilian market. However, the expansion of the crop has faced problems such as the lack of good materials and inadequate management, restricting the production increase occasioning by low yield and fruit quality. It is known that there is a high susceptibility of current cultivars to major diseases, such as the virus of fruit hardening (CABMV - Cowpea aphid-borne mosaic virus) and such as bacterial blight (Xanthomonas axonopodis pv. Passiflorae). These diseases cause leaf spots but can induce defoliation and even death of branches. Therefore, the development of resistant cultivars to disease is very important. Thus, this study aimed to evaluate the reaction of 48 passion fruit progenies to bacterial illness and fruits woodiness virus, under field conditions, in Federal District. It was used a randomized block design, with five plants per plot and four replications. The progenies used were the same as Chapter 3 and 4. According to the table notes it was observed that: about the virus, forty-five progenies were classified as MS and three progeny as S. As for bacteriose, thirty-one progenies were classified as MS and eleven progenies as MR. For viruses, the heritability coefficient was low, indicating low genetic variability for this character, different from bacteriose which showed high values of heritability and relation $\mathrm{CVg} / \mathrm{CVe}$, indicating high genetic variability.
\end{abstract}

Keywords: xanthomonas axonopodis pv. passiflorae, breeding, virus of fruit hardening. 


\section{1 - INTRODUÇÃO}

O cultivo do maracujá em escala comercial iniciou-se no Brasil a partir da década de 1970 (LIMA \& CUNHA, 2004). Com o aumento das áreas cultivadas observou-se também o surgimento de diversos problemas de ordem fitossanitária em todas as regiões do país.

Muitas das espécies de maracujá são cultivadas pelas propriedades alimentícias, ornamentais e medicinais, principalmente, pela qualidade de seus frutos (SOUZA \& MELETTI, 1997; TOCCHINI et al., 1994).

Muitos trabalhos têm mostrado que espécies silvestres do gênero Passiflora (P. laurifolia, $P$. nitida, $P$. tenuifilla, $P$. mucronata, $P$. giberti, $P$. amethytina, $P$. quadrangularis, $P$. setacea, $P$. coccinea, $P$. cerulea, entre outras) têm apresentado, variabilidade para resistência às principais doenças do maracujazeiro (CUNHA et al., 2002; SANTOS FILHO \& JUNQUEIRA, 2003) e também variabilidade genética (VIEIRA et al., 1997; ANGEL et al., 1998; CASSIANO et al., 1998; CROCHEMORE, 2002; PIO VIANA et al., 2003; FALEIRO et al., 2005). Várias dessas espécies têm sido citadas como potenciais fontes de resistências que podem contribuir para o controle de doenças causadas por fungos (SANTOS FILHO \& SANTOS, 2003), bactérias (SEIXAS, 1989, 2003) e alguns vírus (REZENDE, 1994).

Em campo aberto, o desempenho agronômico e a resistência a fitopatógenos necessitam de um trabalho contínuo de melhoramento genético, pois existem poucas cultivares de maracujazeiro disponíveis aos produtores brasileiros cuja produtividade é considerada de regular a baixa. Outro problema enfrentado pela cultura é a pequena longevidade da lavoura, que decresceu consideravelmente nos últimos anos.

Por isso, a utilização de cultivares resistentes, em conjunto com outras técnicas de manejo integrado, são medidas eficazes, ecológicas e econômicas utilizadas no controle de doenças em plantas. Observando as características do maracujazeiro de baixa produtividade e alta suscetibilidade das cultivares atuais às principais doenças, a estratégia de desenvolvimento de cultivares resistentes a doenças e produtivas é muito importante num programa de melhoramento genético da cultura (JUNQUEIRA et al., 2003; FALEIRO et al., 2005).

Estudos detalhados de caracterização, seleção e hibridação de genótipos de maracujazeiro são essenciais para subsidiar a utilização do germoplasma de Passiflora em programas de 
melhoramento genético e na obtenção de materiais produtivos, com boa qualidade de frutos e com resistência ou tolerância aos principais fitopatógenos do maracujazeiro-azedo.

A virose do endurecimento dos frutos é uma doença do maracujazeiro, podendo atingir mais de $70 \%$ das plantas em pomares infectados. Está presente nas principais áreas produtoras do Brasil. Os sintomas se caracterizam pela presença de mosaicos nas folhas, que podem ser ou não acompanhados de bolhosidades e deformações. Os frutos podem apresentar-se deformados, pequenos e duros (BARBOSA \& BRAGANÇA, 2006).

Quanto a bactérias existem poucas doenças causadas por elas na cultura do maracujazeiro, porém são responsáveis por causarem danos consideráveis, sendo de ocorrência generalizada e frequentemente associada a outras doenças. Afetam a parte área da planta ocasionando sintomas como: manchas e murchas em folhas e frutos, dificultando a sua comercialização.

Nesse sentido, esse trabalho teve como objetivo avaliar a reação de quarenta e oito progênies de maracujazeiro-azedo à virose do endurecimento dos frutos e bacteriose em condições de campo, no Distrito Federal.

\section{2 - MATERIAL E MÉTODOS}

O trabalho foi conduzido na Fazenda Água Limpa, pertencente à Universidade de Brasília (UnB), situada na Vargem Bonita, $25 \mathrm{~km}$ ao sul do Distrito Federal, com latitude de $16^{\circ} \mathrm{Sul}$, longitude de $48^{\circ}$ Oeste e $1.100 \mathrm{~m}$ de altitude. O clima da região é do tipo $\mathrm{AW}$, caracterizado por chuvas concentradas no verão, de outubro a abril, e invernos secos de maio a setembro (MELO, 1999).

O experimento foi instalado em solo Latossolo Vermelho-Amarelo, fase argilosa, profundo, com boa drenagem. Na área experimental foi realizada a calagem e a incorporação de $1 \mathrm{~kg}$ de superfosfato simples por cova em pré-plantio. A análise de solo apresentou os seguintes resultados: $\mathrm{Al}$ (0,05 meq); $\mathrm{Ca}+\mathrm{Mg}$ (1,9 meq); $\mathrm{P}$ (4,5 ppm); K (46 ppm); Ph 5,4 e saturação de $\mathrm{Al}$ 4\%. As adubações de cobertura foram realizadas em círculo, à distância de 40 a $50 \mathrm{~cm}$ do colo da planta superficialmente, enquanto o superfosfato simples foi incorporado no solo.

Foram avaliadas quarenta e oito progênies, num delineamento de blocos casualizados, com cinco plantas por parcela e quatro repetições. As progênies utilizadas foram Gig. Amar Pl.2; FB200; Rosa Int. Pl.1; EC3-0 Pl.1; MSCA; MSCA Pl.1; MSCA Pl.2; Gig. Amar. Pl.1; PES 9; Rosa Int.Pl.3; Rosa Claro Pl.3; Rosa Claro Pl.1; Rubi Gig. Pl.1; AR 2; ECL -7; PA 01; 
RC3; Rosa Int. P1.2; Rosa Claro 2; Rubi. Gig. P1.2; EC3-0; AP1; ECRAM P1.2; ECRAM P1.3; Gig.Amar.Pl.3; MAR20\#44; MAR20\#44 Pl.1; MAR20\#24 Pl.1; MAR20\#24 Pl.2; MAR20\#10; MAR20\#12 Pl.1; MAR20\#12 Pl.2; MAR20\#15; MAR20\#21; MAR20\#19; MAR20\#41; MAR20\#34; MAR20\#34 Pl.7; MAR20\#39; MAR20\#46 Pl.1; MAR20\#46 P1.2; MAR20\#46 Pl.3; MAR20\#2005 Pl.1; MAR20\#2005 P1.2; MAR20\#2005 P1.3; MAR20\#2005 Pl.4; 20\#34 F2; e GAZ P1.1. (São as mesmas progênies do Capítulo 3). Essas progênies foram desenvolvidas a partir de trabalhos de pesquisa desenvolvidos pela Universidade de Brasília UnB e Embrapa Cerrados. Têm origem de hibridações intraespecíficas e interespecíficas e também de materiais oriundos de seleção massal feita em pomares produtivos da região sudeste do Brasil.

As progênies MAR20\#44; MAR20\#24 (P1 1 e 2); MAR20\#12 (Pl 1 e 2); MAR20\#21; MAR20\#19; MAR20\#41; MAR20\#39; MAR20\#46 (Pl 1, 2 e 3) e MAR 20\#2005 (Pl 1, 2,3 e 4) foram obtidos por seleção massal de plantios comerciais contendo nove materiais superiores, considerando os aspectos de produtividade, qualidade de frutos e resistência aos patógenos, trazidos do município de Araguari, descritos na Tabela 37.

Tabela 37 - Progênies cultivadas em pomares comerciais no município de Araguari/MG utilizados na seleção massal.

\begin{tabular}{|l|l|}
\hline 1 & Maguary “Mesa 1" \\
\hline 2 & Maguary “Mesa 2" \\
\hline 3 & Havaiano \\
\hline 4 & Marília Seleção Cerrado (MSC) \\
\hline 5 & Seleção DF \\
\hline 6 & EC-2-O \\
\hline 7 & $\mathrm{~F}_{1}$ (Marília x Roxo Australiano) \\
\hline 8 & $\mathrm{~F}_{1}[$ Roxo Fiji (introdução das ilhas Fiji) x Marília] \\
\hline 9 & $\begin{array}{l}\text { RC } 1 \text { [F } \text { (Marília (seleção da Cooperativa sul Brasil de Marília }- \text { SP) x Roxo } \\
\text { Australiano) x Marília (pai recorrente)]. }\end{array}$ \\
\hline
\end{tabular}

As progênies MAR20\#10 e MAR 20\#15 foram obtidas através de sementes coletadas do campo experimental da Fazenda Água Limpa - UnB- 2012.

Os materiais denominados, FB-200, Rosa Int., EC 3-0 1, MSCA, PES 9, Rosa Claro, Rubi Gig., AR 2, ECL -7, PA 01, RC3, AP1 e ECRAM 2 foram obtidos conforme descrito na Tabela 38 . 
Tabela 38 - Procedência de progênies de maracujazeiro-azedo avaliados no Distrito Federal, Fazenda Água Limpa - UnB, 2012 e 2013.

\begin{tabular}{|c|c|}
\hline PROGENIES & ORIGEM \\
\hline FB200 & Cultivar comercial \\
\hline Rosa Int. & Seleção recorrente baseada na família de meio irmãos. \\
\hline EC 3-0 1 & $\begin{array}{c}\text { Híbrido }\left(\mathrm{RC}_{1}\right) \text { de polinização controlada entre as cultivares Marília x Roxo } \\
\text { Australiano retrocruzado para Marília, ou seja } \mathrm{F}_{1} \text { x Marília }\end{array}$ \\
\hline MSCA & Marília seleção cerrado \\
\hline PES 9 & $\begin{array}{c}\text { Oriundos da geração } \mathrm{F}_{3} \text { de polinização controlada entre as espécies } P \text {. } \\
\text { edulis e } P \text {. setaceae }\end{array}$ \\
\hline Rosa Claro & Seleção recorrente baseada na família de meio irmãos. \\
\hline MAR 20\#01 & $\begin{array}{l}\text { Seleção recorrente baseada em família de } 1 / 2 \text { irmãos entre diversos } \\
\text { genótipos de Passiflora edulis }\end{array}$ \\
\hline MAR 20\#02 & $\begin{array}{l}\text { Seleção recorrente baseada em família de } 1 / 2 \text { irmãos entre diversos } \\
\text { genótipos de Passiflora edulis }\end{array}$ \\
\hline Rubi Gig & (Roxo australiano x Marília) \\
\hline AR 2 & $\begin{array}{l}\text { Seleção individual de plantas resistentes à antracnose de uma população de } \\
\text { Roxo Australiano }\end{array}$ \\
\hline ECL -7 & Derivado da cultivar Marília \\
\hline PA 01 & Seleção recorrente baseada na família de meio irmãos \\
\hline RC3 & Híbrido de seleção recorrente (P. edulis x P. setacea) \\
\hline EC3-0 & $\begin{array}{l}\text { Híbrido (RC1) de polinização controlada entre as cultivares Marília x } \\
\text { Roxo Australiano retrocruzado para Marília, ou seja, F1 x Marília }\end{array}$ \\
\hline AP1 & $\begin{array}{c}\text { Cultivar obtida do cruzamento entre tipos de maracujá-amarelo de alta } \\
\text { produtividade, selecionados em pomar comercial }\end{array}$ \\
\hline ECRAM 2 & Híbrido entre roxo australiano (P. edulis ) x P. edulis f. flavicarpa \\
\hline
\end{tabular}

As mudas foram obtidas por meio de semeadura em bandejas com setenta e duas células com $125 \mathrm{ml}$ de substrato vermiculita em junho de 2012, sob casa de vegetação localizada na Estação Biológica - UnB. As mudas foram transplantadas para o campo em outubro de 2011, com adubação de $700 \mathrm{~g}$ de superfosfato simples por cova. O espaçamento utilizado foi de 2,8 $\mathrm{m}$ entre linhas e $3 \mathrm{~m}$ entre plantas, totalizando 1.190 plantas por hectare.

A suplementação de água foi feita via sistema de irrigação, sendo realizada da seguinte forma: sete horas de irrigação e um turno de dois dias com média de três litros por metro linear por hora.

Para o plantio, foram aplicados $700 \mathrm{~g}$ de superfosfato simples e $200 \mathrm{~g}$ de calcário dolomítico por cova, além de quatro adubações com intervalo de quinze dias com $200 \mathrm{~g}$ de sulfato de amônio e $100 \mathrm{~g}$ de cloreto de potássio. Após o plantio foram realizadas adubações com periodicidade de quinze em quinze dias. Os níveis de adubação de potássio e nitrogênio foram: $100 \mathrm{~g}$ de sulfato de amônio (20 g de nitrogênio) e $70 \mathrm{~g}$ de cloreto de potássio (40 g de 
$\mathrm{K}_{2} \mathrm{O}$ ). Para a adubação de fósforo, aplicou-se $650 \mathrm{~g} /$ cova de supersimples (117 g de $\left.\mathrm{P}_{2} \mathrm{O}_{5}\right)$ e $250 \mathrm{~g} /$ cova do mesmo adubo (45 $\mathrm{g} \mathrm{P}_{2} \mathrm{O}_{5}$ ). As adubações de cobertura foram realizadas em círculo, à distância de 40 a $50 \mathrm{~cm}$ do colo da planta superficialmente, porém o superfosfato simples foi incorporado no solo. Nos meses de setembro, outubro, novembro, dezembro de 2012 e janeiro de 2013 foram realizadas aplicações de adubo via fertirrigação da seguinte forma: 62,5 g/cova de ureia (30 g/cova de nitrogênio), $100 \mathrm{~g} /$ cova de cloreto de potássio branco (60 g/cova de $\mathrm{K}_{2} \mathrm{O}$ ) e $200 \mathrm{~g} /$ cova de nitrabor (30 g/cova de nitrogênio, $40 \mathrm{~g} /$ cova de cálcio e $0,4 \mathrm{~g} /$ cova de boro).

Foi feita adubação foliar com (N-P-K) 4-16-16 e micronutrientes a $600 \mathrm{ml}$ em vinte litros de água, totalizando a aplicação de 140 litros/ha de calda, com bomba costal. Para o controle das lagartas Dione juno Juno, Agraulisvanillae vanillae e percevejos, foi realizada uma aplicação de Decis ${ }^{\circledR}(500 \mathrm{ml} / \mathrm{ha})$ adicionado de 1 litro/ha de óleo mineral Assist ${ }^{\circledR}$ em janeiro de 2013. E para o controle de ácaro, e também com efeito sobre esses insetos, foi feita uma aplicação de $\operatorname{Vexter}^{\mathrm{R}}$ (abamectina) a $100 \mathrm{ml} / \mathrm{ha}$ com óleo mineral Iharol@ 1 litro/ha em julho de 2012. O controle das plantas daninhas na linha foi feito com aplicação de glifosato (200 $\mathrm{ml})$ mais $50 \mathrm{~g}$ de ureia por bomba costal de vinte litros.

A lavoura foi conduzida utilizando o sistema de sustentação de espaldeira vertical, com mourões distanciados de seis metros e dois fios de arame liso a dois metros de altura e outro a 1,50 metro em relação ao solo. As plantas foram conduzidas em haste única, tutoradas por barbante até o arame, deixando para fio de arame duas brotações laterais em sentido contrário uma a outra. As brotações, a partir daí, cresceram livremente, não tendo sido realizadas podas de renovação.

As colheitas foram realizadas somente dos frutos que se encontravam no chão, ou seja, a partir de sua maturação total. Os frutos colhidos, aleatoriamente, eram colocados em caixas de plástico e separados para avaliação visual dos sintomas das doenças que se deve à percepção e à quantificação de lesões na superfície do fruto, utilizando a margem de representação de dez frutos por parcela. Não houve inoculação de doenças, sendo considerada a pressão de inóculo natural, sob condições de campo. O período de avaliações ocorreu de janeiro a agosto de 2013, totalizando em quatro avaliações nas épocas como descrito a seguir:

\begin{tabular}{|c|c|}
\hline ÉPOCA & MÊS-ANO \\
\hline 1 & Janeiro-Fevereiro de 2013 \\
\hline 2 & Março-Abril de 2013 \\
\hline 3 & Maio-Junho de 2013 \\
\hline 4 & Julho-Agosto de 2013 \\
\hline
\end{tabular}


O grau de resistência à bacteriose foi avaliado utilizando-se a escala de notas criada por JUNQUEIRA et al. (2003). Dessa forma, o grau de resistência à bacteriose foi obtido utilizando a escala de notas como mostra a Tabela 39.

Tabela 39 - Notas e sintomas visuais utilizados para análise dos frutos de quarenta e oito progênies de maracujazeiro-azedo, proposta por JUNQUEIRA et al., (2003).

\begin{tabular}{|c|l|c|}
\hline NOTAS & \multicolumn{1}{|c|}{ DESCRIÇÃO } & CLASSES \\
\hline 1 & Sem sintomas de doenças & Resistente (R) \\
\hline 2 & $\begin{array}{l}\text { Até 10\% da superfície coberta por } \\
\text { lesões }\end{array}$ & \begin{tabular}{l} 
Moderadamente suscetível (MR) \\
Suscetíveis (S) \\
\hline 3
\end{tabular} \\
\hline 4 & $\begin{array}{l}\text { Maior 30,01\% da sup. coberta por } \\
\text { lesões }\end{array}$ & Altamente suscetíveis (AS) \\
\hline
\end{tabular}

Para a avaliação do vírus nas plantas de maracujá no campo seguiu-se a metodologia proposta por SOUSA (2005) onde avalia-se a severidade e incidência do vírus (CABMV) coletando-se vinte folhas, na extremidade superior dos ramos excluindo as folhas mais novas e com ataque de ácaro, em espaços regulares (dez folhas em cada lado da parcela) e atribuindo notas de acordo com a Tabela 39. Com base nas médias das notas encontradas, obteve-se o índice de severidade à virose do endurecimento dos frutos a qual foi utilizada para identificar o grau de resistência da progênie à virose.

Tabela 40 - Notas e sintomas visuais utilizados para análise das folhas.

\begin{tabular}{|c|c|}
\hline NOTA & SINTOMAS VISUAIS \\
\hline 1 & Folha sem sintoma de mosaico (Resistente - R) \\
\hline 2 & $\begin{array}{c}\text { Folha apresentando mosaico leve e sem deformações foliares } \\
\text { (Medianamente Suscetível }- \text { MS) }\end{array}$ \\
\hline 3 & $\begin{array}{c}\text { Folha apresentando mosaico leve, deformações na superfície das folhas } \\
\text { (parecido com bolhas). (Suscetível - S) }\end{array}$ \\
\hline 4 & $\begin{array}{c}\text { Folha apresentando mosaico severo, deformações na superfície das folhas e } \\
\text { do limbo foliar (Altamente suscetível - AS) }\end{array}$ \\
\hline
\end{tabular}

*Escala diagramática 1 - Análise visual de sintomas da Virose do Endurecimento dos Frutos. 
As análises estatísticas foram realizadas com o auxílio dos softwares SISVAR (FERREIRA, 2000) e GENES (CRUZ, 2007).

Os dados sem transformação foram submetidos à análise de variância, utilizando para o teste de F o nível de 5\% de probabilidade. As médias foram agrupadas pelo teste de ScottKnott (FERREIRA, 2000).

A partir dos dados observados nas avaliações da severidade da virose e da bacteriose, foi obtida a curva do progresso das doenças e então calculada a área (AACPD).

\section{3 - RESULTADOS E DISCUSSÃO}

Fazendo breve correlação com o presente trabalho que realizou as avaliações em quatro diferentes épocas ( $1^{\mathrm{a}}$ - janeiro-fevereiro; $2^{\mathrm{a}}$ - março-abril; $3^{\mathrm{a}}$ - maio-junho; $4^{\mathrm{a}}$-julho-agosto), pode-se observar que não houve interações significativas entre as progênies nas épocas $1^{\mathrm{a}}$ e $4^{\mathrm{a}}$ para a virose do endurecimento dos frutos tanto para incidência quanto para severidade.

COIMBRA (2010) registrou maior incidência e severidade médias no mês de julho de 2009 com $76 \%$ e 2,37\%, respectivamente. SOUSA (2009) encontrou no primeiro ano de avaliação nos meses de abril e maio de 2008 maiores índices de incidência com 89,81\% e $84,33 \%$. A severidade também foi alta nesses meses de avaliação com nota 2,22 . No segundo ano de avaliação, a maior incidência foi verificada em dezembro de 2008 com 95,29\% e a menor em fevereiro de 2009 com $85 \%$. Esse mesmo autor relatou maior severidade no mês de março de 2009 com nota 2,6.

GONÇALVES (2011) obteve maior severidade média com a progênie MAR20\#40 $(2,67)$ e a menor em MAR20\#21 (2,10). A maior incidência média foi obtida pelo mesmo autor em MAR20\#49 (87,18\%) e a menor em MAR20\#15(71,56\%).

ABREU (2006) observou a severidade máxima de 2,33 nos meses de março e junho de 2005. SOUSA (2005) observou a severidade máxima no mês de abril de 2005 de 2,00. SOUSA (2009) no primeiro ano de avaliação encontrou maior severidade nos meses de abril e maio 2008 com 2,22 em ambos os meses e a menor severidade no mês de março de 2008 $(2,06)$. No segundo ano de avaliação, no mês de março de 2009 observou-se a maior severidade $(2,60)$ e a menor em dezembro de 2008 com 2,28.

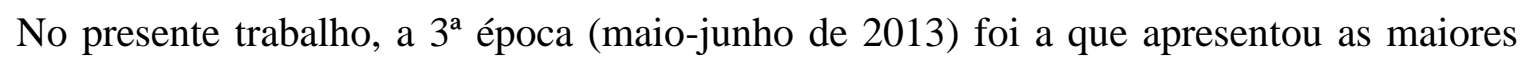
quantidades de notas de severidade com valores superiores às outras épocas. Tal fato demostra que a intensidade da doença entre as épocas são variáveis, tornando-se importante 
avaliar as progênies em várias condições ambientais, favoráveis e desfavoráveis ao desenvolvimento da doença.

De acordo com a escala diagramática proposta por JUNQUEIRA et al.(2003), modificada por SOUSA (2005), utilizando severidade média da doença em folhas das vinte e seis progênies estudadas e estimado o grau de resistência das mesmas. O presente trabalho classificou quarenta e cinco das suas progênies como medianamente suscetíveis ao vírus do endurecimento dos frutos e três progênies como suscetíveis (MAR20\#39, Rosa Intenso Pl.1 e MAR20\#34 Pl.7) ao vírus do endurecimento dos frutos.

Para o trabalho de GONÇALVES (2011), as progênies MAR20\#40, MAR20\#49 e YM FB100 foram consideradas suscetíveis ao vírus do endurecimento dos frutos enquanto as demais foram classificadas como medianamente resistentes.

Outros autores apresentaram as seguintes classificações quanto ao grau de resistência. COIMBRA (2014) classificou as catorze progênies estudadas como moderadamente resistentes. SOUSA (2009), trabalhando com vinte e seis progênies, classificou-as como suscetíveis nos dois anos de avaliação. ABREU (2006), trabalhando com seis progênies em campo aberto e inóculo natural, classificou as progênies como moderadamente suscetíveis.

Ainda no presente estudo de acordo com a Tabela 40, verifica-se quanto à classificação do grau de resistência os seguintes detalhamentos dentro de cada época estudada. $\mathrm{Na} 1^{\mathrm{a}}$ época, a progênie Rosa Int. Pl.1 foi suscetível, na 2a época (MAR20\#39, RC3, Rosa Int. Pl.1 e Rubi Gig. Pl.2), na $3^{\mathrm{a}}$ época (MAR20\#24 Pl.1, MSCA Pl.1, MSCA Pl.2 e MAR20\#34 Pl.7) e na $4^{\mathrm{a}}$ época (MAR20\#2005 Pl.2, MAR20\#2005 Pl.4, 20\#34 F2 e PA01) as progênies foram classificadas também como suscetíveis.

KASSANIS (1957) afirma que a maioria das viroses apresenta menor taxa de replicação em temperaturas próximas a $30{ }^{\circ} \mathrm{C}$ e param de replicar em temperaturas próximas a $36{ }^{\circ} \mathrm{C}$. Sendo a temperatura o principal parâmetro climático que influencia a interação planta-vírus e responsável pelo crescimento de uma planta e a maneira como esta responde à infecção, podendo inclusive, ocasionar a quebra da resistência a determinadas viroses. Além disso, é o principal fator que determina a severidade dos sintomas e os danos econômicos provocados por uma virose, uma vez que afeta a taxa de replicação e o movimento do vírus na planta. 
Tabela 41 - Incidência de virose nas quatro diferentes épocas em quarenta e oito progênies de maracujazeiro-zedo.

\begin{tabular}{|c|c|c|c|c|c|}
\hline \multicolumn{6}{|c|}{ CABMV (INCIDÊNCIA) } \\
\hline PROGÊNIES & 1 & 2 & 3 & 4 & MÉDIA \\
\hline $\begin{array}{c}\text { MAR20\#2005 } \\
\text { Pl.1 }\end{array}$ & $0,69 \mathrm{aA}$ & $0,69 \mathrm{aA}$ & $0,8 \mathrm{aB}$ & $0,83 \mathrm{aA}$ & 0,75 \\
\hline $\begin{array}{c}\text { MAR20\#2005 } \\
\text { PI.2 }\end{array}$ & $0,88 \mathrm{aA}$ & $0,83 \mathrm{aB}$ & $0,78 \mathrm{aA}$ & $0,94 \mathrm{aA}$ & 0,86 \\
\hline $\begin{array}{c}\text { MAR20\#2005 } \\
\text { Pl.3 }\end{array}$ & $0,77 \mathrm{aA}$ & $0,83 \mathrm{aB}$ & $0,88 \mathrm{aB}$ & $0,92 \mathrm{aA}$ & 0,85 \\
\hline $\begin{array}{c}\text { MAR20\#2005 } \\
\text { Pl.4 }\end{array}$ & $0,74 \mathrm{aA}$ & $0,79 \mathrm{aA}$ & $0,79 \mathrm{aB}$ & $0,94 \mathrm{aA}$ & 0,82 \\
\hline 20\#34 F2 & $0,81 \mathrm{aA}$ & $0,90 \mathrm{aB}$ & $0,75 \mathrm{aA}$ & $0,91 \mathrm{aA}$ & 0,84 \\
\hline AP 01 & $0,78 \mathrm{aA}$ & $0,68 \mathrm{aA}$ & $0,74 \mathrm{aA}$ & $0,87 \mathrm{aA}$ & 0,77 \\
\hline AR 2 & $0,65 \mathrm{aA}$ & $0,78 \mathrm{aA}$ & $0,66 \mathrm{aA}$ & $0,82 \mathrm{aA}$ & 0,73 \\
\hline EC3-0 & $0,83 \mathrm{aA}$ & $0,83 \mathrm{aB}$ & $0,85 \mathrm{aB}$ & $0,79 \mathrm{aA}$ & 0,83 \\
\hline EC3-0 PI.1 & $0,78 \mathrm{aA}$ & $0,73 \mathrm{aA}$ & $0,78 \mathrm{aB}$ & $0,82 \mathrm{aA}$ & 0,78 \\
\hline ECL 7 & $0,75 \mathrm{aA}$ & $0,75 \mathrm{aA}$ & $0,76 \mathrm{aA}$ & $0,69 \mathrm{aA}$ & 0,74 \\
\hline ECRAM PI.2 & $0,79 \mathrm{aA}$ & $0,82 \mathrm{aB}$ & $0,77 \mathrm{aA}$ & $0,77 \mathrm{aA}$ & 0,79 \\
\hline ECRAM PI.3 & $0,83 \mathrm{aA}$ & $0,73 \mathrm{aA}$ & $0,84 \mathrm{aB}$ & $0,86 \mathrm{aA}$ & 0,82 \\
\hline FB 200 & $0,80 \mathrm{aA}$ & $0,79 \mathrm{aA}$ & $0,76 \mathrm{aA}$ & $0,78 \mathrm{aA}$ & 0,78 \\
\hline GAZ Pl.1 & $0,75 \mathrm{aA}$ & $0,82 \mathrm{aB}$ & $0,88 \mathrm{aB}$ & $0,79 \mathrm{aA}$ & 0,81 \\
\hline $\begin{array}{l}\text { Gig. Amar } \\
\text { Pl.1 }\end{array}$ & $0,68 \mathrm{aA}$ & $0,76 \mathrm{aA}$ & $0,64 \mathrm{aA}$ & $0,80 \mathrm{aA}$ & 0,72 \\
\hline $\begin{array}{l}\text { Gig. Amar } \\
\text { Pl.2 }\end{array}$ & $0,64 \mathrm{aA}$ & $0,76 \mathrm{aA}$ & $0,83 \mathrm{aB}$ & $0,78 \mathrm{aA}$ & 0,75 \\
\hline $\begin{array}{c}\text { Gig. Amar } \\
\text { Pl.3 }\end{array}$ & $0,78 \mathrm{aA}$ & $0,9 \mathrm{aB}$ & $0,74 \mathrm{aA}$ & $0,79 \mathrm{aA}$ & 0,80 \\
\hline MAR20\#10 & $0,85 \mathrm{aA}$ & $0,73 \mathrm{aA}$ & $0,66 \mathrm{aA}$ & $0,77 \mathrm{aA}$ & 0,75 \\
\hline $\begin{array}{l}\text { MAR20\#12 PI. } \\
2\end{array}$ & $0,74 \mathrm{aA}$ & $0,74 \mathrm{aA}$ & $0,85 \mathrm{aB}$ & $0,78 \mathrm{aA}$ & 0,78 \\
\hline MAR20\#15 & $0,78 \mathrm{aA}$ & $0,70 \mathrm{aA}$ & $0,86 \mathrm{aB}$ & $0,76 \mathrm{aA}$ & 0,78 \\
\hline MAR20\#19 & $0,69 \mathrm{aA}$ & $0,78 \mathrm{aA}$ & $0,83 \mathrm{aB}$ & $0,82 \mathrm{aA}$ & 0,78 \\
\hline $\begin{array}{c}\text { MAR20\#24 } \\
\text { Pl.1 }\end{array}$ & $0,82 \mathrm{aA}$ & $0,88 \mathrm{aB}$ & $0,9 \mathrm{aB}$ & $0,87 \mathrm{aA}$ & 0,87 \\
\hline $\begin{array}{c}\text { MAR20\#24 } \\
\text { Pl.2 }\end{array}$ & $0,85 \mathrm{aA}$ & $0,73 \mathrm{aA}$ & $0,63 \mathrm{aA}$ & $0,82 \mathrm{aA}$ & 0,76 \\
\hline MAR20\#34 & $0,75 \mathrm{aA}$ & $0,87 \mathrm{aB}$ & $0,94 \mathrm{aB}$ & $0,9 \mathrm{aA}$ & 0,87 \\
\hline MAR20\#39 & $0,87 \mathrm{aA}$ & $0,95 \mathrm{aB}$ & $0,81 \mathrm{aB}$ & $0,85 \mathrm{aA}$ & 0,87 \\
\hline MAR20\#41 & $0,74 \mathrm{aA}$ & $0,74 \mathrm{aA}$ & $0,72 \mathrm{aA}$ & $0,76 \mathrm{aA}$ & 0,74 \\
\hline MAR20\#44 & $0,75 \mathrm{aA}$ & $0,67 \mathrm{aA}$ & $0,69 \mathrm{aA}$ & $0,8 \mathrm{aA}$ & 0,73 \\
\hline $\begin{array}{c}\text { MAR20\#44 } \\
\text { Pl.1 }\end{array}$ & $0,77 \mathrm{aA}$ & $0,87 \mathrm{aB}$ & $0,65 \mathrm{aA}$ & $0,77 \mathrm{aA}$ & 0,77 \\
\hline MAR20\#46 & $0,82 \mathrm{aA}$ & $0,85 \mathrm{aB}$ & $0,78 \mathrm{aB}$ & $0,88 \mathrm{aA}$ & 0,83 \\
\hline MAR20\#46 & $0,89 \mathrm{aA}$ & $0,80 \mathrm{aB}$ & $0,90 \mathrm{aB}$ & $0,84 \mathrm{aA}$ & 0,86 \\
\hline
\end{tabular}




\begin{tabular}{|c|c|c|c|c|c|}
\hline Pl.1 & & & & \\
\hline $\begin{array}{c}\text { MAR20\#46 } \\
\text { PI.2 }\end{array}$ & $0,76 \mathrm{aA}$ & $0,70 \mathrm{aA}$ & $0,81 \mathrm{aB}$ & $0,71 \mathrm{aA}$ & 0,75 \\
\hline MSCA & $0,76 \mathrm{aA}$ & $0,84 \mathrm{aB}$ & $0,81 \mathrm{aB}$ & $0,76 \mathrm{aA}$ & 0,79 \\
\hline MSCA Pl.1 & $0,68 \mathrm{aA}$ & $0,85 \mathrm{bB}$ & $0,92 \mathrm{bB}$ & $0,84 \mathrm{bA}$ & 0,82 \\
\hline MSCA PI.2 & $0,76 \mathrm{aA}$ & $0,72 \mathrm{aA}$ & $0,86 \mathrm{aB}$ & $0,84 \mathrm{aA}$ & 0,79 \\
\hline PA 01 & $0,71 \mathrm{aA}$ & $0,76 \mathrm{aA}$ & $0,80 \mathrm{aB}$ & $0,84 \mathrm{aA}$ & 0,77 \\
\hline RC 3 & $0,82 \mathrm{aA}$ & $0,87 \mathrm{aB}$ & $0,88 \mathrm{aB}$ & $0,85 \mathrm{aA}$ & 0,85 \\
\hline $\begin{array}{c}\text { Rosa Claro } \\
\text { Pl.1 }\end{array}$ & $0,84 \mathrm{aA}$ & $0,80 \mathrm{aB}$ & $0,68 \mathrm{aA}$ & $0,83 \mathrm{aA}$ & 0,78 \\
\hline Rosa Int Pl.1 & $0,88 \mathrm{aA}$ & $0,87 \mathrm{aB}$ & $0,75 \mathrm{aA}$ & $0,89 \mathrm{aA}$ & 0,85 \\
\hline Rosa Int Pl.2 & $0,80 \mathrm{aA}$ & $0,80 \mathrm{aB}$ & $0,80 \mathrm{aB}$ & $0,82 \mathrm{aA}$ & 0,80 \\
\hline Rosa Int Pl.3 & $0,79 \mathrm{aA}$ & $0,76 \mathrm{aA}$ & $0,85 \mathrm{aB}$ & $0,80 \mathrm{aA}$ & 0,80 \\
\hline Rubi Gig. PI.1 & $0,78 \mathrm{aA}$ & $0,72 \mathrm{aA}$ & $0,70 \mathrm{aA}$ & $0,77 \mathrm{aA}$ & 0,74 \\
\hline Rubi Gig. PI.2 & $0,74 \mathrm{aA}$ & $0,93 \mathrm{aB}$ & $0,82 \mathrm{aB}$ & $0,85 \mathrm{aA}$ & 0,83 \\
\hline $\begin{array}{c}\text { MAR20\#34 } \\
\text { PI.7 }\end{array}$ & $0,75 \mathrm{aA}$ & $0,80 \mathrm{aB}$ & $0,89 \mathrm{aB}$ & $0,88 \mathrm{aA}$ & 0,83 \\
\hline $\begin{array}{c}\text { MAR20\#44 } \\
\text { PI.1 }\end{array}$ & $0,78 \mathrm{aA}$ & $0,85 \mathrm{aB}$ & $0,83 \mathrm{aB}$ & $0,75 \mathrm{aA}$ & 0,80 \\
\hline ECRAM Pl.2 & $0,70 \mathrm{aA}$ & $0,86 \mathrm{aB}$ & $0,76 \mathrm{aA}$ & $0,81 \mathrm{aA}$ & 0.78 \\
\hline $\begin{array}{c}\text { GAZ Pl.1 } \\
\text { Gig. Amar. } \\
\text { Pl.3 }\end{array}$ & $0,57 \mathrm{aA}$ & $0,72 \mathrm{aA}$ & $0,63 \mathrm{aA}$ & $0,67 \mathrm{Aa}$ & 0,65 \\
\hline $\begin{array}{c}\text { MAR20\#46 } \\
\text { PI.3 }\end{array}$ & $0,72 \mathrm{aA}$ & $0,89 \mathrm{bB}$ & $0,95 \mathrm{bB}$ & $0,93 \mathrm{bA}$ & 0,87 \\
\hline MA & $0,65 \mathrm{aA}$ & $0,80 \mathrm{bB}$ & $0,85 \mathrm{bA}$ & 0,78 \\
\hline
\end{tabular}

*Médias seguidas pela mesma letra, minúsculas, nas linhas e maiúsculas, nas colunas, não diferem estatisticamente, entre si, pelo teste de Scott Knott ao nível de 5\%.

Tabela 42 - Severidade de virose nas quatro diferentes épocas em quarenta e oito progênies de maracujazeiro-azedo.

\begin{tabular}{|c|c|c|c|c|c|}
\hline \multicolumn{7}{|c|}{ CABMV (SEVERIDADE) } \\
\hline $\begin{array}{c}\text { PROGÊNIES } \\
\begin{array}{c}\text { MAR20\#2005 } \\
\text { PI.1 }\end{array}\end{array}$ & $\mathbf{1}, 20 \mathrm{aA}$ & $2,16 \mathrm{aA}$ & $2,25 \mathrm{aA}$ & $2,10 \mathrm{aA}$ & $2,2 \mathrm{MS}$ \\
\hline $\begin{array}{c}\text { MAR20\#2005 } \\
\text { PI.2 }\end{array}$ & $2,85 \mathrm{aA}$ & $2,89 \mathrm{aB}$ & $2,48 \mathrm{aA}$ & $3,14 \mathrm{aA}$ & $2,8 \mathrm{MS}$ \\
\hline $\begin{array}{c}\text { MAR20\#2005 } \\
\text { Pl.3 }\end{array}$ & $2,42 \mathrm{aA}$ & $2,87 \mathrm{aB}$ & $3,04 \mathrm{aB}$ & $2,88 \mathrm{aA}$ & $2,8 \mathrm{MS}$ \\
\hline $\begin{array}{c}\text { MAR20\#2005 } \\
\text { PI.4 }\end{array}$ & $2,18 \mathrm{aA}$ & $2,45 \mathrm{aA}$ & $2,65 \mathrm{aB}$ & $3,10 \mathrm{bA}$ & $2,6 \mathrm{MS}$ \\
\hline 20\#34 F2 & $2,61 \mathrm{aA}$ & $2,94 \mathrm{aB}$ & $2,70 \mathrm{aB}$ & $3,05 \mathrm{aA}$ & $2,8 \mathrm{MS}$ \\
\hline AP 01 & $2,34 \mathrm{aA}$ & $2,42 \mathrm{aA}$ & $2,42 \mathrm{aA}$ & $3,03 \mathrm{aA}$ & $2,5 \mathrm{MS}$ \\
\hline AR 2 & $2,00 \mathrm{aA}$ & $2,33 \mathrm{aA}$ & $2,64 \mathrm{aB}$ & $2,64 \mathrm{aA}$ & $2,4 \mathrm{MS}$ \\
\hline EC3-0 & $2,84 \mathrm{aA}$ & $2,93 \mathrm{aB}$ & $2,96 \mathrm{aB}$ & $2,78 \mathrm{aA}$ & $2,8 \mathrm{MS}$ \\
\hline EC3-0 PI.1 & $2,30 \mathrm{aA}$ & $2,19 \mathrm{aA}$ & $2,89 \mathrm{aB}$ & $2,72 \mathrm{aA}$ & $2,5 \mathrm{MS}$ \\
\hline
\end{tabular}




\begin{tabular}{|c|c|c|c|c|c|}
\hline ECL 7 & $2,41 \mathrm{aA}$ & $2,30 \mathrm{aA}$ & $2,26 \mathrm{aA}$ & $2,55 \mathrm{aA}$ & $2,4 \mathrm{MS}$ \\
\hline ECRAM PI.2 & $2,65 \mathrm{aA}$ & $2,81 \mathrm{aB}$ & $2,76 \mathrm{aB}$ & $2,91 \mathrm{aA}$ & $2,8 \mathrm{MS}$ \\
\hline ECRAM PI.3 & $2,55 \mathrm{aA}$ & $2,45 \mathrm{aA}$ & $2,91 \mathrm{aB}$ & $2,91 \mathrm{aB}$ & $2,8 \mathrm{MS}$ \\
\hline FB 200 & $2,49 \mathrm{aA}$ & $2,44 \mathrm{aA}$ & $2,60 \mathrm{aB}$ & $2,60 \mathrm{aB}$ & $2,5 \mathrm{MS}$ \\
\hline GAZ PI.1 & $2,23 \mathrm{aA}$ & $2,51 \mathrm{aA}$ & $2,95 \mathrm{aB}$ & $2,71 \mathrm{aA}$ & $2,6 \mathrm{MS}$ \\
\hline $\begin{array}{l}\text { Gig. Amar } \\
\text { Pl.1 }\end{array}$ & $2,71 \mathrm{aA}$ & $2,40 \mathrm{EaA}$ & $2,14 \mathrm{aA}$ & $2,97 \mathrm{aA}$ & 2,6 MS \\
\hline $\begin{array}{l}\text { Gig. Amar } \\
\text { Pl.2 }\end{array}$ & $2,22 \mathrm{aA}$ & $2,69 \mathrm{aB}$ & $2,69 \mathrm{aB}$ & $2,48 \mathrm{aA}$ & 2,5 MS \\
\hline $\begin{array}{c}\text { Gig. Amar } \\
\text { Pl.3 }\end{array}$ & $2,39 \mathrm{aA}$ & $2,90 \mathrm{aB}$ & $2,31 \mathrm{aA}$ & $2,74 \mathrm{aA}$ & $2,6 \mathrm{MS}$ \\
\hline MAR20\#10 & $2,19 \mathrm{bA}$ & $2,40 \mathrm{bA}$ & $1,91 \mathrm{aA}$ & $2,74 \mathrm{bA}$ & $2,3 \mathrm{MS}$ \\
\hline $\begin{array}{c}\text { MAR20\#12 } \\
\text { PI.2 }\end{array}$ & $2,58 \mathrm{aA}$ & $2,53 \mathrm{aA}$ & $2,78 \mathrm{aB}$ & $2,56 \mathrm{aA}$ & 2,6 MS \\
\hline MAR20\#15 & $2,52 \mathrm{aA}$ & $2,62 \mathrm{aB}$ & $2,76 \mathrm{aB}$ & $2,71 \mathrm{aA}$ & 2,6 MS \\
\hline MAR20\#19 & $2,13 \mathrm{aA}$ & $2,41 \mathrm{aA}$ & $2,97 \mathrm{aB}$ & $2,70 \mathrm{aA}$ & $2,5 \mathrm{MS}$ \\
\hline $\begin{array}{c}\text { MAR20\#24 } \\
\text { PI.1 }\end{array}$ & $2,35 \mathrm{aA}$ & $2,15 \mathrm{aB}$ & $3,12 \mathrm{aB}$ & $2,94 \mathrm{aA}$ & 2,6 MS \\
\hline $\begin{array}{c}\text { MAR20\#24 } \\
\text { Pl.2 }\end{array}$ & $2,60 \mathrm{aA}$ & $2,12 \mathrm{aA}$ & $2,00 \mathrm{aA}$ & $2,55 \mathrm{aA}$ & 2,3 MS \\
\hline MAR20\#34 & $2,22 \mathrm{aA}$ & $2,88 \mathrm{bB}$ & $2,98 \mathrm{bB}$ & $2,91 \mathrm{bA}$ & $2,7 \mathrm{MS}$ \\
\hline MAR20\#39 & $2,81 \mathrm{aA}$ & $3,50 \mathrm{bB}$ & $2,70 \mathrm{aB}$ & $2,84 \mathrm{aA}$ & $3,0 \mathrm{~S}$ \\
\hline MAR20\#41 & $2,43 \mathrm{aA}$ & $2,46 \mathrm{aA}$ & $2,26 \mathrm{aA}$ & $2,56 \mathrm{aA}$ & $2,4 \mathrm{MS}$ \\
\hline MAR20\#44 & $2,28 \mathrm{aA}$ & $2,25 \mathrm{aA}$ & $2,38 \mathrm{aA}$ & $2,80 \mathrm{aA}$ & $2,4 \mathrm{MS}$ \\
\hline $\begin{array}{c}\text { MAR20\#44 } \\
\text { PI.1 } \\
\end{array}$ & $2,33 \mathrm{aA}$ & $2,58 \mathrm{aA}$ & $1,95 \mathrm{aA}$ & $2,55 \mathrm{aA}$ & 2,3 MS \\
\hline MAR20\#46 & $2,79 \mathrm{aA}$ & $2,68 \mathrm{aB}$ & $2,85 \mathrm{aB}$ & $2,79 \mathrm{aA}$ & $2,8 \mathrm{MS}$ \\
\hline $\begin{array}{c}\text { MAR20\#46 } \\
\text { Pl.1 }\end{array}$ & $2,93 \mathrm{aA}$ & $2,73 \mathrm{aB}$ & $2,98 \mathrm{aB}$ & $2,85 \mathrm{aA}$ & 2,9 MS \\
\hline $\begin{array}{c}\text { MAR20\#46 } \\
\text { PI.2 }\end{array}$ & $2,26 \mathrm{aA}$ & $2,23 \mathrm{aA}$ & $2,43 \mathrm{aA}$ & $2,59 \mathrm{aA}$ & $2,4 \mathrm{MS}$ \\
\hline MSCA & $2,49 \mathrm{aA}$ & $2,73 \mathrm{aB}$ & $2,91 \mathrm{aB}$ & $2,54 \mathrm{aA}$ & $2,7 \mathrm{MS}$ \\
\hline MSCA PI.1 & $2,51 \mathrm{aA}$ & $2,92 \mathrm{aB}$ & $3,06 \mathrm{aB}$ & $2,93 \mathrm{aA}$ & $2,9 \mathrm{MS}$ \\
\hline MSCA PI.2 & $2,68 \mathrm{aA}$ & $2,62 \mathrm{aB}$ & $3,08 \mathrm{aB}$ & $2,90 \mathrm{aA}$ & $2,9 \mathrm{MS}$ \\
\hline PA 01 & $2,13 \mathrm{aA}$ & $2,05 \mathrm{aA}$ & $2,70 \mathrm{bB}$ & $2,64 \mathrm{bA}$ & $2,4 \mathrm{MS}$ \\
\hline RC 3 & $2,13 \mathrm{aA}$ & $3,05 \mathrm{aB}$ & $2,88 \mathrm{aB}$ & $2,72 \mathrm{aA}$ & $2,7 \mathrm{MS}$ \\
\hline $\begin{array}{c}\text { Rosa Claro } \\
\text { Pl.1 }\end{array}$ & $2,15 \mathrm{aA}$ & $2,47 \mathrm{aA}$ & $2,40 \mathrm{aA}$ & $2,73 \mathrm{aA}$ & $2,4 \mathrm{MS}$ \\
\hline Rosa Int Pl.1 & $3,20 \mathrm{aA}$ & $3,01 \mathrm{aB}$ & $2,66 \mathrm{aB}$ & 3,18 aA & $3,0 \mathrm{~S}$ \\
\hline Rosa Int Pl.2 & $2,40 \mathrm{aA}$ & $2,64 \mathrm{aB}$ & $2,66 \mathrm{aB}$ & $2,85 \mathrm{aA}$ & $2,6 \mathrm{MS}$ \\
\hline Rosa Int Pl.3 & $2,38 \mathrm{aA}$ & $2,63 \mathrm{aB}$ & $2,86 \mathrm{aB}$ & $2,68 \mathrm{aA}$ & $2,6 \mathrm{MS}$ \\
\hline Rubi Gig. Pl.1 & $3,42 \mathrm{aA}$ & $2,08 \mathrm{aA}$ & $2,41 \mathrm{aA}$ & $2,85 \mathrm{aA}$ & $2,7 \mathrm{MS}$ \\
\hline Rubi Gig. Pl.2 & $2,74 \mathrm{aA}$ & $3,08 \mathrm{aB}$ & $2,83 \mathrm{aB}$ & $2,85 \mathrm{aA}$ & 2,9 MS \\
\hline $\begin{array}{c}\text { MAR20\#34 } \\
\text { PI.7 }\end{array}$ & $2,34 \mathrm{aA}$ & $2,91 \mathrm{aB}$ & $3,09 \mathrm{aB}$ & $2,95 \mathrm{aA}$ & $3,1 \mathrm{~S}$ \\
\hline $\begin{array}{c}\text { MAR20\#44 } \\
\text { Pl.1 }\end{array}$ & $2,37 \mathrm{aA}$ & $2,75 \mathrm{aB}$ & $2,80 \mathrm{aB}$ & $2,55 \mathrm{aA}$ & 2,6 MS \\
\hline
\end{tabular}




\begin{tabular}{|c|c|c|c|c|c|}
\hline ECRAM PI.2 & $2,03 \mathrm{aA}$ & $2,40 \mathrm{aA}$ & $2,63 \mathrm{aB}$ & $2,62 \mathrm{aA}$ & $2,4 \mathrm{MS}$ \\
\hline GAZ Pl.1 & $2,03 \mathrm{aA}$ & $2,10 \mathrm{aA}$ & $2,23 \mathrm{aA}$ & $2,38 \mathrm{aA}$ & $2,2 \mathrm{MS}$ \\
\hline $\begin{array}{c}\text { Gig. Amar. } \\
\text { Pl.3 }\end{array}$ & $2,48 \mathrm{aA}$ & $2,14 \mathrm{aA}$ & $2,77 \mathrm{aB}$ & $2,80 \mathrm{aA}$ & $2,5 \mathrm{MS}$ \\
\hline $\begin{array}{c}\text { MAR20\#46 } \\
\text { Pl.3 }\end{array}$ & $2,19 \mathrm{aA}$ & $2,58 \mathrm{aA}$ & $3,03 \mathrm{aB}$ & $2,25 \mathrm{aA}$ & $2,5 \mathrm{MS}$ \\
\hline
\end{tabular}

*Médias seguidas pela mesma letra, minúsculas, nas linhas e maiúsculas, nas colunas, não diferem estatisticamente, entre si, pelo teste de Scott Knott ao nível de 5\%.

Para bacteriose, no presente trabalho foi observada diferença estatísica quanto à incidência e severidade da bacteriose em todas as épocas, além disso, foi perceptível a ocorrência numa mesma época de diferentes progênies apresentarem 100\% dos seus frutos atacados e $0 \%$ dos seus frutos atacados para a mesma época.

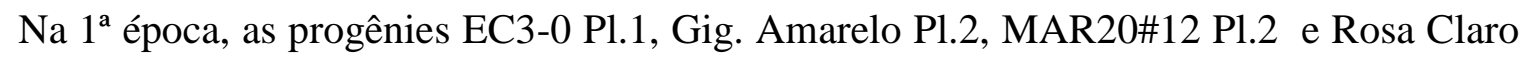
Pl.1 tiveram todos os frutos atacados. Também na $1^{\mathrm{a}}$ época as progênies Gig. Amar. Pl.3 e MAR20\#46 tiveram as menores taxas de ocorrência do patógeno.

$\mathrm{Na} 2^{\mathrm{a}}$ época, as progênies FB200, Gigante Amar. Pl.3, MAR20\#19, MAR20\#24 Pl.1, MAR20\#34, MAR20\#41, Rubi Gig. Pl.1 e Rubi Gig. Pl.2 tiveram todos os frutos atacados.

Na progênie EC3-0 Pl.1 houve diferença estatística entre as épocas, no entanto, apenas na $2^{\mathrm{a}}$ época teve menor incidência da doença em todas as outras épocas a incidência foi alta. $\mathrm{Na}$ progênie MAR20\#46 foi evidente verificarmos que a doença só apareceu a partir da $2^{\mathrm{a}}$ época.

$\mathrm{Na} 3^{\mathrm{a}}$ época, as progênies Gigante Amar. Pl.1, MSCA Pl.2 e Rosa Int. Pl.3 tiveram todos os frutos atacados. Na $3^{\mathrm{a}}$ época, as progênies MAR20\#12 Pl.2 e MAR20\#46 Pl.1 tiveram entre 50 e $60 \%$ de taxa de incidência apresentando as menores taxas para a época.

$\mathrm{Na} 4$ a época, as progênies MAR20\#34 e RC3 tiveram todos os frutos atacados.

$\mathrm{Na} 4^{\mathrm{a}}$ época, as progênies MAR20\#2005 Pl.4, MAR20\#46 Pl.1, MSCA Pl.1, PA01 e Rosa Claro Pl.1 apresentaram taxa de incidência entre 60-65\% enquanto todas as outras progênies apresentaram valores maiores.

COIMBRA (2010) observou em trabalho de campo que a máxima incidência de bacteriose nas catorze progênies variou de 73,50\% em FP01 a 92,50\% em MAR20\#36. No geral, a incidência máxima ficou em torno de $80 \%$. A incidência máxima foi observada em MAR20\#36, com 92,50\% seguida de RC3, 91,75\%. Já a incidência mínima variou de 13,25\% em AR01 a 60\% em MAR20\#23. Para a progênie RC3 no estudo em questão na $4^{a}$ época todos os frutos foram atacados $(100 \%)$.

Foi observada incidência máxima em pelo menos uma das épocas nas seguintes progênies: EC3-0 Pl.1, FB200, Gig. Amar. P1.1, Gig. Amar. P1.2, Gig. Amar. Pl.3, 
MAR20\#12 Pl.2, MAR20\#19, MAR20\#24 Pl.1, MAR20\#34, MAR20\#41, MSCA Pl.2, RC3, Rosa claro P1.1, Rubi Gig. Pl.1 e Rubi Gig. Pl.2 e mínima apenas na progênie MAR20\#46.

SOUSA (2009) em experimento de campo, em seu primeiro ano, encontrou efeito significativo para incidência de bacteriose sendo a máxima incidência verificada em MAR20\#29 que apresentou 41,47\% diferindo da progênie MAR20\#41 que obteve 16,67\%, a menor incidência. Já nas avaliações feitas no segundo ano, SOUSA (2009) observou na progênie MAR20\#29 a maior incidência de 60,60\% diferindo estatisticamente da progênie MAR20\#39 que teve a menor incidência de 26,60\% para a mesma progênie no presente trabalho a variação da incidência ficou entre $(80,00-96,66 \%)$ entre as quatro épocas.

VILELA (2011), no que se refere a incidência à bacteriose percebeu que a progênie que apresentou maior média de incidência foi a MAR20\#15 (80,75\%) e a que obteve a menor média foi MAR20\#49 com 54,06\% de incidência.

VILELA (2011) observando a severidade média da doença em frutos das trinta e duas progênies estudadas verificou que o grau de resistência de todas as progênies avaliadas, comportaram-se como suscetíveis à bacteriose (MAR20\#40, Planta 1, AR 01, AR 02, Planta 5, Planta 7, MAR20\#03) e as demais como moderadamente resistentes.

Em trabalho realizado em campo, COIMBRA (2010) observou que as progênies MAR20\#23, EC-RAM, MAR20\#03, MAR20\#46, AP1 e MAR20\#36 tiveram as maiores severidades ao longo dos meses avaliados ficando com 10,25\%; 11,00\%; 12,50\%; 10,75\%; 16,25 e $12,25 \%$ de área superficial de fruto lesionada. A menor severidade média ficou com FB200 seguida de MAR20\#23, AR02 e FP1. 5,65; 5,75; 5,95 e 6,00. Indicando boa tolerância desses à bacteriose nestas condições edafoclimáticas.

SOUSA (2009) observou à severidade de bacteriose sendo a progênie MAR 20\#24 a que apresentou a maior severidade $(3,15 \%)$ diferindo das progênies MAR20\#39, FB100 e MAR20\#2005, 1,35\%, $1,18 \%$ e $1,25 \%$ que apresentaram as menores severidades, respectivamente. Já MIRANDA (2004) encontrou 7,47\% de severidade em MAR20\#15.

A progênie MAR20\#46 se destacou em todas as épocas por apresentar a severidade baixa, assim, mais tolerante.

A Tabela 44 mostra na escala de notas criada por JUNQUEIRA et al. (2003), com modificações, que na $1^{\text {a }}$ época as progênies mantiveram as médias dentro da faixa moderadamente resistente (MR) em sua totalidade. A progênie Gig. Amar. Pl.1 apresentou a maior média, sendo considerado MS, e a progênie que apresentou a menor média foi a 
MAR20\#46 sendo considerado MR. Confirmando a progênie MAR20\#46 como sendo a que manteve a severidade mais baixa, ou seja, menos favorável à doença.

As épocas 3 e 4 foram as que menos favoreceram à doença numa proporção de $50 \%$ a menos quando comparado com as épocas 1 e 2.

As progênies MAR20\#2005 Pl.2, MAR20\#2005 P1.3, ECRAM Pl.2, ECRAM Pl.3, MAR20\#19, MSCA e Rosa Int.P13 não diferiram ao longo das quatro épocas mantendo-se com valores alto ao longo de todo o experimento.

A progênie Gig. Amar. Pl.3 se mateve em todas as épocas com severidade constante, sendo assim, podemos dizer que apresentou características favoráveis à seleção.

Tabela 43 - Incidência de bacteriose nas quatro diferentes épocas em quarenta e duas progênies de maracujazeiro-azedo.

\begin{tabular}{|c|c|c|c|c|c|}
\hline \multicolumn{6}{|c|}{ XANTHOMONAS (INCIDÊNCIA) } \\
\hline PROGÊNIES & 1 & 2 & 3 & 4 & MÉDIA \\
\hline MAR20\#2005 Pl.1 & $83,33 \mathrm{aD}$ & $96,87 \mathrm{bB}$ & $73,33 \mathrm{aB}$ & $75,00 \mathrm{aB}$ & 82,13 \\
\hline MAR20\#2005 Pl.2 & $85,00 \mathrm{aD}$ & $80,55 \mathrm{aA}$ & $76,66 \mathrm{aB}$ & $93,33 \mathrm{aC}$ & 83,88 \\
\hline MAR20\#2005 PI.3 & $88,88 \mathrm{aE}$ & $86,87 \mathrm{aA}$ & $83,33 \mathrm{aC}$ & $82,22 \mathrm{aC}$ & 85,32 \\
\hline MAR20\#2005 Pl.4 & $63,33 \mathrm{aC}$ & $93,33 \mathrm{bB}$ & $92,50 \mathrm{bC}$ & $65,00 \mathrm{aA}$ & 78,54 \\
\hline $20 \# 34$ F2 & $75,00 \mathrm{aD}$ & $80,00 \mathrm{aA}$ & $90,00 \mathrm{aC}$ & $90,00 \mathrm{aC}$ & 83,75 \\
\hline AP 01 & $62,50 \mathrm{aC}$ & $86,60 \mathrm{bA}$ & $85,00 \mathrm{bC}$ & $95,00 \mathrm{bC}$ & 82,27 \\
\hline AR2 & $80,00 \mathrm{bD}$ & $86,66 \mathrm{bA}$ & $70,00 \mathrm{aB}$ & $90,00 \mathrm{bC}$ & 81,66 \\
\hline EC3-0 & $78,75 \mathrm{aD}$ & $91,66 \mathrm{bB}$ & $73,33 \mathrm{aB}$ & $77,50 \mathrm{aB}$ & 80,31 \\
\hline EC3-0 Pl.1 & $100,00 \mathrm{bE}$ & $66,60 \mathrm{aA}$ & $90,00 \mathrm{bC}$ & $90,00 \mathrm{bC}$ & 86,65 \\
\hline ECL7 & $75,00 \mathrm{aD}$ & $83,92 \mathrm{aA}$ & $83,33 \mathrm{aC}$ & $70,00 \mathrm{aB}$ & 78,06 \\
\hline ECRAM PI.2 & $95,00 \mathrm{aE}$ & $95,00 \mathrm{aB}$ & $90,00 \mathrm{aC}$ & $90,00 \mathrm{aC}$ & 92,50 \\
\hline ECRAM PI.3 & $75,00 \mathrm{aD}$ & $81,85 \mathrm{aA}$ & $90,00 \mathrm{aC}$ & $90,00 \mathrm{aC}$ & 84,21 \\
\hline FB 200 & $61,73 \mathrm{aC}$ & $100,00 \mathrm{cB}$ & $95,00 \mathrm{cC}$ & $80,00 \mathrm{bB}$ & 84,18 \\
\hline GAZ PI.1 & $85,71 \mathrm{aD}$ & $90,00 \mathrm{aB}$ & $80,00 \mathrm{aB}$ & $86,67 \mathrm{aC}$ & 85,59 \\
\hline Gig.Amar. Pl.1 & $85,00 \mathrm{aD}$ & $90,00 \mathrm{aB}$ & $100,00 \mathrm{aC}$ & $90,00 \mathrm{aC}$ & 91,25 \\
\hline Gig.Amar. PI.2 & $100,00 \mathrm{bE}$ & $80,00 \mathrm{aA}$ & $90,00 \mathrm{bC}$ & $80,00 \mathrm{aB}$ & 87,50 \\
\hline Gig.Amar. Pl.3 & $10,00 \mathrm{aA}$ & $100,00 \mathrm{bB}$ & $90,00 \mathrm{bC}$ & $90,00 \mathrm{bC}$ & 72,50 \\
\hline MAR20\#10 & $61,66 \mathrm{aC}$ & $96,60 \mathrm{bB}$ & $87,50 \mathrm{bC}$ & $70,00 \mathrm{aB}$ & 78,94 \\
\hline MAR20\#12 PI.2 & $100,00 \mathrm{cE}$ & $80,00 \mathrm{bA}$ & $50,00 \mathrm{aA}$ & $73,30 \mathrm{bB}$ & 75,82 \\
\hline MAR20\#15 & $70,00 \mathrm{aD}$ & $96,60 \mathrm{bB}$ & $85,00 \mathrm{bC}$ & $85,00 \mathrm{bC}$ & 84,15 \\
\hline MAR20\#19 & $84,40 \mathrm{aD}$ & $100,00 \mathrm{aB}$ & $97,50 \mathrm{aC}$ & $90,00 \mathrm{aC}$ & 92,97 \\
\hline MAR20\#24 PI.1 & $60,00 \mathrm{aC}$ & $100,00 \mathrm{bB}$ & $90,00 \mathrm{bC}$ & $85,00 \mathrm{bC}$ & 83,75 \\
\hline MAR20\#24 PI.2 & $55,92 \mathrm{aC}$ & $95,00 \mathrm{cB}$ & $70,00 \mathrm{bB}$ & $75,00 \mathrm{bB}$ & 73,98 \\
\hline MAR20\#34 & $69,16 \mathrm{aD}$ & $100,00 \mathrm{bB}$ & $80,00 \mathrm{aB}$ & $100,00 \mathrm{bC}$ & 87,29 \\
\hline MAR20\#39 & $85,23 \mathrm{aD}$ & $88,80 \mathrm{aB}$ & $96,66 \mathrm{aC}$ & $80,00 \mathrm{aB}$ & 87,67 \\
\hline MAR20\#41 & $82,50 \mathrm{aD}$ & $100,00 \mathrm{bB}$ & $82,50 \mathrm{aC}$ & $86,70 \mathrm{aC}$ & 87,92 \\
\hline MAR20\#44 & $91,60 \mathrm{aE}$ & $88,80 \mathrm{aB}$ & $75,00 \mathrm{aB}$ & $80,00 \mathrm{aB}$ & 83,85 \\
\hline MAR20\#44 PI.1 & $40,00 \mathrm{aB}$ & $85,00 \mathrm{bA}$ & $81,90 \mathrm{bC}$ & $75,00 \mathrm{bB}$ & 70,47 \\
\hline MAR20\#46 & $00,00 \mathrm{aA}$ & $85,00 \mathrm{bA}$ & $75,00 \mathrm{bB}$ & $70,00 \mathrm{bC}$ & 57,5 \\
\hline MAR20\#46 Pl.1 & $90,00 \mathrm{bE}$ & $76,60 \mathrm{bA}$ & $60,00 \mathrm{aA}$ & $60,00 \mathrm{aA}$ & 71,65 \\
\hline MAR20\#46 PI.2 & $47,00 \mathrm{aB}$ & $87,50 \mathrm{bA}$ & $80,00 \mathrm{bB}$ & $70,00 \mathrm{bB}$ & 71,12 \\
\hline
\end{tabular}




\begin{tabular}{|c|c|c|c|c|c|}
\hline MSCA & $60,00 \mathrm{aC}$ & $88,80 \mathrm{bB}$ & $73,30 \mathrm{aB}$ & $90,00 \mathrm{bC}$ & 78,02 \\
\hline MSCA Pl.1 & $93,00 \mathrm{bE}$ & $80,00 \mathrm{bA}$ & $90,00 \mathrm{bC}$ & $65,00 \mathrm{aA}$ & 82,00 \\
\hline MSCA PI.2 & $76,60 \mathrm{aD}$ & $93,30 \mathrm{bB}$ & $100,00 \mathrm{bC}$ & $90,00 \mathrm{bC}$ & 89,97 \\
\hline PA01 & $70,00 \mathrm{aD}$ & $92,00 \mathrm{bB}$ & $90,00 \mathrm{bC}$ & $60,00 \mathrm{aA}$ & 78,00 \\
\hline RC3 & $85,70 \mathrm{aD}$ & $75,00 \mathrm{aA}$ & $80,00 \mathrm{aB}$ & $100,00 \mathrm{bC}$ & 85,17 \\
\hline Rosa Claro Pl.1 & $100,00 \mathrm{bE}$ & $96,70 \mathrm{bB}$ & $87,00 \mathrm{bC}$ & $60,00 \mathrm{aA}$ & 85,92 \\
\hline Rosa Int. Pl.1 & $95,00 \mathrm{bE}$ & $70,00 \mathrm{aA}$ & $70,00 \mathrm{aB}$ & $72,00 \mathrm{aB}$ & 76,75 \\
\hline Rosa .Int. Pl.2 & $95,80 \mathrm{bE}$ & $95,00 \mathrm{bB}$ & $80,00 \mathrm{aB}$ & $76,70 \mathrm{aB}$ & 86,87 \\
\hline Rosa Int. Pl.3 & $80,00 \mathrm{aD}$ & $75,00 \mathrm{aA}$ & $100,00 \mathrm{bC}$ & $70,00 \mathrm{aB}$ & 81,25 \\
\hline Rubi Gig. Pl.1 & $60,00 \mathrm{aC}$ & $100,00 \mathrm{bB}$ & $90,00 \mathrm{bC}$ & $70,00 \mathrm{aB}$ & 80,00 \\
\hline Rubi Gig. Pl.2 & $67,00 \mathrm{aC}$ & $100,00 \mathrm{bB}$ & $90,00 \mathrm{bC}$ & $93,30 \mathrm{bC}$ & 87,57 \\
\hline
\end{tabular}

*Médias seguidas pela mesma letra, minúsculas, nas linhas e maiúsculas, nas colunas, não diferem estatisticamente, entre si, pelo teste de Scott Knott ao nível de $5 \%$.

Tabela 44 - Severidade de bacteriose nas quatro diferentes épocas em quarenta e duas progênies de maracujazeiro-azedo.

\begin{tabular}{|c|c|c|c|c|c|}
\hline \multicolumn{6}{|c|}{ XANTHOMONAS (Severidade) } \\
\hline Progênies & 1 & 2 & 3 & 4 & $\begin{array}{c}\text { Média- } \\
\text { GR }\end{array}$ \\
\hline MAR20\#2005 Pl.1 & $2,3 \mathrm{bE}$ & $2,6 \mathrm{cC}$ & $1,8 \mathrm{aA}$ & $1,7 \mathrm{aA}$ & $2,1 \mathrm{MS}$ \\
\hline MAR20\#2005 PI.2 & $2,1 \mathrm{aE}$ & $2,1 \mathrm{aA}$ & $1,9 \mathrm{aA}$ & $2,1 \mathrm{aB}$ & $2,0 \mathrm{MS}$ \\
\hline MAR20\#2005 Pl.3 & $2,0 \mathrm{aE}$ & $2,2 \mathrm{aB}$ & $1,9 \mathrm{aA}$ & $1,8 \mathrm{aA}$ & $2,0 \mathrm{MS}$ \\
\hline MAR20\#2005 PI.4 & $1,6 \mathrm{aC}$ & $2,2 \mathrm{bB}$ & $2,3 \mathrm{bC}$ & $1,8 \mathrm{aA}$ & $2,0 \mathrm{MS}$ \\
\hline $20 \# 34$ F2 & $1,8 \mathrm{aD}$ & $1,8 \mathrm{aA}$ & $1,9 \mathrm{aA}$ & $2,2 \mathrm{bB}$ & $1,9 \mathrm{MR}$ \\
\hline AP 01 & $1,6 \mathrm{aC}$ & $2,0 \mathrm{bA}$ & $1,9 \mathrm{bA}$ & $2,1 \mathrm{bB}$ & $1,9 \mathrm{MR}$ \\
\hline AR2 & $2,2 \mathrm{bE}$ & $2,0 \mathrm{bA}$ & $1,7 \mathrm{aA}$ & $2,2 \mathrm{bB}$ & $2,0 \mathrm{MS}$ \\
\hline EC3-0 & $1,8 \mathrm{aD}$ & $2,3 \mathrm{bC}$ & $1,9 \mathrm{aA}$ & $1,9 \mathrm{aA}$ & $2,0 \mathrm{MS}$ \\
\hline EC30 Pl.1 & $2,5 \mathrm{bF}$ & $2,0 \mathrm{aA}$ & $2,1 \mathrm{aB}$ & $2,1 \mathrm{aB}$ & $2,2 \mathrm{MS}$ \\
\hline ECL 7 & $2,3 \mathrm{bE}$ & $2,4 \mathrm{bC}$ & $1,9 \mathrm{aA}$ & $1,7 \mathrm{aB}$ & $2,1 \mathrm{MS}$ \\
\hline ECRAM PI.2 & $2,1 \mathrm{aE}$ & $2,2 \mathrm{aB}$ & $1,9 \mathrm{aA}$ & $2,2 \mathrm{aB}$ & $2,1 \mathrm{MS}$ \\
\hline ECRAM PI.3 & $2,0 \mathrm{aF}$ & $2,2 \mathrm{aB}$ & $1,9 \mathrm{aA}$ & $1,9 \mathrm{aA}$ & $2,0 \mathrm{MS}$ \\
\hline FB 200 & $1,7 \mathrm{aC}$ & $2,2 \mathrm{bB}$ & $2,1 \mathrm{bB}$ & $1,9 \mathrm{aA}$ & $2,0 \mathrm{MS}$ \\
\hline GAZ PI.1 & $2,3 \mathrm{bE}$ & $2,5 \mathrm{bC}$ & $2,2 \mathrm{aB}$ & $2,0 \mathrm{aB}$ & $2,2 \mathrm{MS}$ \\
\hline Gig.Amar. Pl.1 & $2,2 \mathrm{aE}$ & $2,6 \mathrm{bC}$ & $2,6 \mathrm{bD}$ & $2,3 \mathrm{aB}$ & $2,4 \mathrm{MS}$ \\
\hline Gig.Amar. PI.2 & $2,4 \mathrm{bF}$ & $2,0 \mathrm{aA}$ & $2,0 \mathrm{aB}$ & $1,9 \mathrm{aA}$ & $2,1 \mathrm{MS}$ \\
\hline Gig.Amar. Pl.3 & $1,3 \mathrm{aB}$ & $2,2 \mathrm{bB}$ & $2,1 \mathrm{bB}$ & $2,0 \mathrm{bB}$ & $1,9 \mathrm{MR}$ \\
\hline MAR20\#10 & $1,8 \mathrm{aD}$ & $2,4 \mathrm{bC}$ & $2,1 \mathrm{bB}$ & $1,9 \mathrm{aA}$ & $2,0 \mathrm{MS}$ \\
\hline MAR20\#12 Pl.2 & $2,8 \mathrm{aG}$ & $1,9 \mathrm{bA}$ & $1,5 \mathrm{aA}$ & $1,9 \mathrm{bA}$ & $2,0 \mathrm{MS}$ \\
\hline MAR20\#15 & $2,0 \mathrm{aD}$ & $2,4 \mathrm{bC}$ & $1,9 \mathrm{aA}$ & $2,1 \mathrm{aB}$ & $2,1 \mathrm{MS}$ \\
\hline MAR20\#19 & $2,2 \mathrm{aE}$ & $2,4 \mathrm{aC}$ & $2,3 \mathrm{aC}$ & $2,0 \mathrm{aB}$ & 2,2 MS \\
\hline MAR20\#24 PI.1 & $1,9 \mathrm{aD}$ & $2,6 \mathrm{bC}$ & $2,1 \mathrm{aB}$ & $2,0 \mathrm{aB}$ & $2,1 \mathrm{MS}$ \\
\hline MAR20\#24 PI.2 & $1,6 \mathrm{aC}$ & $2,0 \mathrm{bA}$ & $1,7 \mathrm{aA}$ & $1,8 \mathrm{bA}$ & $1,8 \mathrm{MR}$ \\
\hline MAR20\#34 & $1,7 \mathrm{aD}$ & $3,1 \mathrm{cD}$ & $1,8 \mathrm{aA}$ & $2,2 \mathrm{bB}$ & $2,2 \mathrm{MS}$ \\
\hline MAR20\#39 & $2,2 \mathrm{aE}$ & $2,6 \mathrm{bC}$ & $2,3 \mathrm{aC}$ & $2,0 \mathrm{aB}$ & 2,3 MS \\
\hline MAR20\#41 & $2,1 \mathrm{aE}$ & $2,5 \mathrm{bC}$ & $2,0 \mathrm{aB}$ & $2,1 \mathrm{aB}$ & $2,2 \mathrm{MS}$ \\
\hline MAR20\#44 & $2,2 \mathrm{bE}$ & $2,5 \mathrm{bC}$ & $1,8 \mathrm{aA}$ & $1,9 \mathrm{aA}$ & $2,1 \mathrm{MS}$ \\
\hline MAR20\#44 PI.1 & $1,4 \mathrm{aB}$ & $2,0 \mathrm{bA}$ & $2,0 \mathrm{bA}$ & $2,0 \mathrm{bB}$ & $1,8 \mathrm{MR}$ \\
\hline
\end{tabular}




\begin{tabular}{|c|c|c|c|c|c|}
\hline MAR20\#46 & $1,0 \mathrm{aA}$ & $2,0 \mathrm{bA}$ & $1,9 \mathrm{bA}$ & $2,0 \mathrm{bB}$ & $1,7 \mathrm{MR}$ \\
\hline MAR20\#46 PI.1 & $2,2 \mathrm{bE}$ & $1,9 \mathrm{aA}$ & $1,6 \mathrm{aA}$ & $1,6 \mathrm{aA}$ & $1,8 \mathrm{MR}$ \\
\hline MAR20\#46 PI.2 & $1,5 \mathrm{aC}$ & $2,3 \mathrm{cB}$ & $1,9 \mathrm{bA}$ & $1,8 \mathrm{bA}$ & $1,9 \mathrm{MR}$ \\
\hline MSCA & $1,7 \mathrm{aC}$ & $2 \mathrm{aA}$ & $1,7 \mathrm{aA}$ & $1,9 \mathrm{aA}$ & $1,8 \mathrm{MR}$ \\
\hline MSCA PI.1 & $2,4 \mathrm{bE}$ & $2,2 \mathrm{bB}$ & $2,1 \mathrm{bB}$ & $1,8 \mathrm{aA}$ & $2,1 \mathrm{MS}$ \\
\hline MSCA PI.2 & $1,8 \mathrm{aD}$ & $2,3 \mathrm{bB}$ & $2,1 \mathrm{aB}$ & $2,4 \mathrm{bB}$ & $2,1 \mathrm{MS}$ \\
\hline PA01 & $1,9 \mathrm{aD}$ & $2,2 \mathrm{bB}$ & $2,0 \mathrm{bB}$ & $1,7 \mathrm{aA}$ & $1,9 \mathrm{MR}$ \\
\hline RC3 & $2,0 \mathrm{aD}$ & $1,9 \mathrm{aA}$ & $1,9 \mathrm{aA}$ & $2,3 \mathrm{bB}$ & $2,0 \mathrm{MS}$ \\
\hline Rosa Claro PI.1 & $2,8 \mathrm{cG}$ & $2,2 \mathrm{bB}$ & $2,1 \mathrm{bB}$ & $1,6 \mathrm{aA}$ & $2,2 \mathrm{MS}$ \\
\hline Rosa Int. PI.1 & $2,6 \mathrm{bF}$ & $1,9 \mathrm{aA}$ & $2,0 \mathrm{aB}$ & $1,8 \mathrm{aA}$ & $2,1 \mathrm{MS}$ \\
\hline Rosa Int. PI.2 & $2,5 \mathrm{bF}$ & $2,3 \mathrm{bC}$ & $1,8 \mathrm{aA}$ & $1,9 \mathrm{aA}$ & $2,1 \mathrm{MS}$ \\
\hline Rosa Int. PI.3 & $1,8 \mathrm{aD}$ & $1,9 \mathrm{aA}$ & $2,1 \mathrm{aB}$ & $1,9 \mathrm{aA}$ & $1,9 \mathrm{MR}$ \\
\hline Rubi Gig. PI.1 & $1,9 \mathrm{aD}$ & $2,9 \mathrm{bD}$ & $2,0 \mathrm{aB}$ & $1,7 \mathrm{aA}$ & $2,1 \mathrm{MS}$ \\
\hline Rubi Gig. PI.2 & $1,9 \mathrm{aD}$ & $2,4 \mathrm{bC}$ & $2,0 \mathrm{aB}$ & $2,0 \mathrm{aB}$ & $2,1 \mathrm{MS}$ \\
\hline
\end{tabular}

*Médias seguidas pela mesma letra, minúsculas, nas linhas e maiúsculas, nas colunas, não diferem estatisticamente, entre si, pelo teste de Scott Knott ao nível de 5\%.

É importante dizer que a curva do progresso da doença mostra o desenvolvimento de uma epidemia num período de tempo e é considerada a melhor representação da epidemia (BERGAMIN FILHO \& AMORIM, 1996).

No presente trabalho para Xanthomonas foram avaliadas quarenta e duas progênies que apresentaram diferenças significativas para AACPD. A progênie MAR20\#46 apresentou menor progresso da doença $(79,50)$ e a progênie Gig. Amar. Pl.1 apresentou maior progresso da doença $(112,88)$. Para o vírus (CABMV) foram avaliadas quarenta e oito progênies que apresentaram diferenças significativas para AACPD. A progênie Rosa Claro Pl.1 apresentou menor progresso $(100,39)$ e a progênie Rubi Gig Pl.2 apresentou maior $(131,66)$ progresso da doença como mostra a Tabela 45.

As progênies que se destacaram devem ser avaliadas sob várias condições ambientais, favoráveis e desfavoráveis ao desenvolvimento da doença, para verificar a consistência da resistência.

GONÇAVES (2011) apresentou em seus dados para virose os valores de área abaixo da curva do progresso da virose (AACPD) oscilando de 53,70 em MAR20\#06 a 117,50 em MAR20\#49. COIMBRA (2010) encontrou diferença estatística significativa quanto a AACPD de severidade, que oscilou de 84,97 em GA2-AR1*GA a 142,88 em ECRAM.

MELLO (2009) encontrou a maior AACPD em RC3 com 259,05 e a menor em MAR20\#03 com 214,13.

SOUSA (2009) trabalhando com vinte e seis progênies, encontrou diferença significativa para AACPD. A progênie MAR20\#49 apresentou maior AACPD $(203,02)$ e diferiu de MAR20\#29 $(179,36)$ que teve o menor progresso. No segundo ano de avaliação, o genótipo 
ECL-7 apresentou a maior AACPD $(243,38)$ diferindo estatisticamente da progênie MAR20\#49, que apresentou a menor $(199,13)$.

Tabela 45 - Efeito da bacteriose e virose em progênies de maracujazeiro-azedo a partir das médias da área abaixo da curva de progresso da doença (AACPD) em condições de campo.

\begin{tabular}{|c|c|c|}
\hline PROGÊNIES & Xanthomonas & CABMV \\
\hline MAR20\#2005 PI.1 & $96,08 \mathrm{c}$ & $106,13 a$ \\
\hline MAR20\#2005 PI.2 & $91,18 b$ & $122,25 b$ \\
\hline MAR20\#2005 Pl.3 & $90,15 b$ & $130,80 \mathrm{~b}$ \\
\hline MAR20\#2005 PI.4 & $93,50 \mathrm{~b}$ & $127,30 \mathrm{~b}$ \\
\hline 20\#34 F2 & $86,53 a$ & $110,23 a$ \\
\hline AP 01 & $87,92 b$ & $129,70 b$ \\
\hline AR 2 & $89,00 \mathrm{~b}$ & $118,76 b$ \\
\hline EC3-0 & $91,89 \mathrm{~b}$ & $111,60 \mathrm{a}$ \\
\hline EC3-0 PI.1 & $96,00 \mathrm{c}$ & $115,93 a$ \\
\hline ECL 7 & $95,45 c$ & $120,21 b$ \\
\hline ECRAM PI.2 & $93,75 b$ & $107,00 \mathrm{a}$ \\
\hline ECRAM PI.3 & $91,54 b$ & $129,94 b$ \\
\hline FB 200 & $91,60 \mathrm{~b}$ & $112,88 \mathrm{a}$ \\
\hline GAZ PI.1 & $102,68 d$ & $125,29 b$ \\
\hline Gig. Amar Pl.1 & $112,88 \mathrm{~d}$ & $102,96 a$ \\
\hline Gig. Amar Pl.2 & $92,93 \mathrm{~b}$ & $125,89 b$ \\
\hline Gig. Amar Pl.3 & $89,25 b$ & $128,33 b$ \\
\hline MAR20\#10 & $94,52 \mathrm{c}$ & $118,33 b$ \\
\hline MAR20\#12 Pl. 2 & $86,34 a$ & $118,97 b$ \\
\hline MAR20\#15 & $96,11 \mathrm{c}$ & $113,14 a$ \\
\hline MAR20\#19 & $101,72 d$ & $116,83 a$ \\
\hline MAR20\#24 PI.1 & $99,77 \mathrm{c}$ & $109,22 a$ \\
\hline MAR20\#24 PI.2 & $81,36 \mathrm{a}$ & $130,45 b$ \\
\hline MAR20\#34 & $104,11 d$ & $102,97 a$ \\
\hline MAR20\#39 & $104,03 d$ & $107,63 a$ \\
\hline MAR20\#41 & $99,24 \mathrm{c}$ & $108,21 \mathrm{a}$ \\
\hline MAR20\#44 & $96,08 \mathrm{c}$ & $116,03 \mathrm{a}$ \\
\hline MAR20\#44 Pl.1 & $85,78 \mathrm{a}$ & $127,00 \mathrm{~b}$ \\
\hline MAR20\#46 & $79,50 \mathrm{a}$ & $104,55 a$ \\
\hline MAR20\#46 Pl.1 & $81,26 a$ & $124,76 b$ \\
\hline MAR20\#46 Pl.2 & $88,65 b$ & $128,31 \mathrm{~b}$ \\
\hline MSCA & $82,99 a$ & $116,63 a$ \\
\hline MSCA Pl.1 & $96,73 \mathrm{c}$ & $106,14 a$ \\
\hline MSCA Pl.2 & $96,73 \mathrm{c}$ & $121,18 b$ \\
\hline PA 01 & $91,41 b$ & $129,70 \mathrm{~b}$ \\
\hline
\end{tabular}




\begin{tabular}{|c|c|c|}
\hline RC 3 & $89,25 \mathrm{~b}$ & $120,10 \mathrm{~b}$ \\
\hline Rosa Claro Pl.1 & $98,44 \mathrm{c}$ & $100,39 \mathrm{a}$ \\
\hline Rosa Int Pl.1 & $92,21 \mathrm{~b}$ & $105,62 \mathrm{a}$ \\
\hline Rosa Int Pl. 2 & $95,43 \mathrm{c}$ & $125,33 \mathrm{~b}$ \\
\hline Rosa Int Pl.3 & $88,50 \mathrm{~b}$ & $121,28 \mathrm{~b}$ \\
\hline Rubi Gig. PI. 1 & $100,84 \mathrm{~d}$ & $114,10 \mathrm{a}$ \\
\hline Rubi Gig. Pl.2 & $95,72 \mathrm{c}$ & $131,66 \mathrm{~b}$ \\
\hline MAR20\#34 Pl.7 & - & $102,97 \mathrm{a}$ \\
\hline MAR20\#44 Pl. 1 & - & $126,25 \mathrm{~b}$ \\
\hline ECRAM Pl.2 & - & $107,00 \mathrm{a}$ \\
\hline GAZ Pl.1 & - & $118,88 \mathrm{~b}$ \\
\hline Gig. Amar.Pl.3 & - & $128,33 \mathrm{~b}$ \\
\hline
\end{tabular}

*Médias seguidas pela mesma letra não diferem entre si estatisticamente pelo teste de Scott Knott ao nível de $5 \%$.

Avaliando as estimativas de herdabilidade e razão entre coeficiente e variação genético e ambiental para o vírus CABMV podemos perceber que os valores foram relativamente baixos tanto para incidência quanto para severidade levando-nos a refletir condição desfavorável à seleção, uma vez que a variância genética foi menor que a ambiental. Contrariamente para Xanthomonas observamos que os valores foram altos tanto para incidência quanto para severidade mostrando condição favorável à seleção, visto que a variância genética foi maior que a ambiental.

VILELA (2013) encontrou valores de herdabilidade para severidade de bacteriose com base na média de 46,40\%, valor relativamente baixo, comum considerando a avaliação de doença em condições de campo e relação $\mathrm{CVg} / \mathrm{CVe}$ de 0,46 , evidenciando a maior influência do ambiente sobre a genética diferente do trabalho apresentado que revelou valor de herdabilidade para severidade de bacteriose de $82,76 \%$ e relação CVg/Cve de 1,09 e de incidência de $84,05 \%$ e relação $\mathrm{CVg} / \mathrm{Cve}$ de 1,15 indicando que existe grande variabiliade genética para esse caráter e que métodos simples de melhoramento podem proporcionar ganhos significativos (Tabela 46). 
Tabela 46 - Estimativas de herdabilidade sentido amplo $\left(\mathrm{ha}^{2}\right)$, coeficiente de variação genético $(\mathrm{CVg})$ e razão entre coeficiente e variação genético e ambiental $(\mathrm{CVg} / \mathrm{CVe})$, utilizando-se dados de quarenta e oito progênies de maracujazeiro-azedo.

\begin{tabular}{|c|c|c|}
\hline Parâmetros Genéticos (CABMV) & INCIDÊNCIA & SEVERIDADE \\
\hline ha $^{\mathbf{2}}$ (média família) & $40,13 \%$ & $65,30 \%$ \\
\hline $\mathbf{C v g}$ & $3,73 \%$ & $6,15 \%$ \\
\hline $\mathbf{C V g} / \mathbf{C V e}$ & 0,41 & 0,68 \\
\hline $\begin{array}{c}\text { Parâmetros Genéticos } \\
\text { (Xanthomonas) }\end{array}$ & INCIDÊNCIA & SEVERIDADE \\
\hline ha $^{2}$ (média família) & $84,05 \%$ & $82,76 \%$ \\
\hline $\mathbf{C v g}$ & $7,59 \%$ & $6,92 \%$ \\
\hline $\mathbf{C V g} / \mathbf{C V e}$ & 1,15 & 1,09 \\
\hline
\end{tabular}

*Médias seguidas pela mesma letra não diferem entre si estatisticamente pelo teste de Scott Knott ao nível de $5 \%$.

Incidência: porcentagem (frequência) de plantas doentes em uma amostra ou população (Amorim, 1995).

Severidade: porcentagem da área ou volume de tecido da planta coberto por sintomas é a variável mais utilizada para quantificar doenças foliares (BERGAMIN FILHO \& AMORIM, 1996).

AACPD: Área Abaixo da Curva do Progresso da Doença. 


\section{4 - CONCLUSÕES}

O trabalho classificou a maioria de suas progênies como medianamente suscetíveis ao vírus do endurecimento dos frutos.

Houve diferenças significativas quanto à incidência e severidade da bacteriose em todas as épocas.

De acordo com a escala de notas na $1^{\mathrm{a}}$ época as progênies mantiveram as médias dentro da faixa moderadamente resistente (MR) em sua totalidade.

A progênie MAR20\#46 manteve a severidade mais baixa, ou seja, menos favorável à doença.

A progênie Gig. Amar. Pl.3 se mateve em todas as épocas com severidade constante apresentando caracteristicas favoráveis à seleção.

A bactéria Xanthomonas e o vírus CABMV apresentaram diferenças significativas para AACPD.

Avaliando as estimativas de herdabilidade e razão entre coeficiente e variação genético e ambiental para o vírus CABMV, podemos perceber que houve baixa variabilidade genética para virose.

O trabalho apresentou valor de herdabilidade para severidade de bacteriose de $82,76 \%$ e relação $\mathrm{CVg} / \mathrm{Cve}$ de 1,09 e de incidência de $84,05 \%$ e relação $\mathrm{CVg} / \mathrm{Cve}$ de 1,15 indicando que existe alta variabiliade genética para Xanthomonas. 


\section{REFERÊNCIAS BIBLIOGRÁFICAS}

ABREU, S.P.M. Desempenho agronômico, características físico-químicas e reação a doenças em genótipos de maracujá-azedo cultivados no Distrito Federal. Brasília: Faculdade de Agronomia e Medicina Veterinária, Universidade de Brasília, 2006. p.129 Dissertação de Mestrado em Ciências Agrárias.

ANGEL, F. O.; FAJARDO, D.; GRUM, M.; TOHME, J.; LOBO, M. Genetic variation analysis of the genus Passiflora L. using RAPD markers. Euphytica: Dordrecht, 1998. v.101: p. $341-347$

BARBOSA, C. J.; BRAGANÇA, C. A. D.; Endurecimento dos frutos do maracujazeiro. $1^{\text {a }}$ Ed. Dez 2006. Publicação on-line. www.cnpmf.embrapa.br

Acesso em: 13 de janeiro de 2013.

BERGAMIN FILHO, A.; AMORIM, L. Doenças de plantas tropicais: epidemiologia e controle econômico. São Paulo: Agronômica Ceres, 1996. p. 299.

CASSiAnO, A. P. A. A.; LEMOS, E.G.M.; OlIVEIRA, J.C., Avaliação de espécies de Passiflora através de marcadores moleculares RAPD. Genetics and Molecular Biology, 1998.v.21, n.3, p.214, Suplemento.

COIMBRA, K. G.; Desempenho agronômico de progênies de maracujazeiro azedo no Distrito Federal. Brasília: Faculdade de Agronomia e Medicina Veterinária, Universidade de Brasília, 2010. p.125. Dissertação de Mestrado.

CROCHEMORE, M.L. Diversidade genética do maracujazeiro (Passiflora spp.). In: REUNIÃO TÉCNICA DE PESQUISA EM MARACUJAZEIRO, 3. Viçosa.Anais...Viçosa 2002. p. 69-74.

CRUZ, C. D. Programa Genes: aplicativo computacional em genética e estatística. Edit. UFV. Viçosa. 1997. p. 442.

CUNHA, M.A.P.; BARBOSA, L.V.; JUNQUEIRA, N.T.V. Espécies de maracujazeiro. In: LIMA, A.A. (Ed.) Maracujá produção: aspectos técnicos.29 Brasília: Embrapa Informação Tecnológica, 2002. Frutas do Brasil, n. 15. p.104. 
DOS ANJOS, J.R.N.; JUNQUEIRA, N.T.V; CHARCHAR, M.J.A. Incidência e distribuição do vírus do endurecimento dos frutos do maracujazeiro no cerrado do Brasil Central. Planaltina-DF: Embrapa Cerrados, 2001. Documento $n^{\circ} 30$.

FALEIRO, F.G.; JUNQUEIRA, N.T.V.; BRAGA, M.F. Germoplasma e melhoramento genético do germoplasma - desafio da pesquisa. In: FALEIRO, F.G.; JUNQUEIRA, N.T.V.; BRAGA, M.F. (Ed.) Maracujá germoplasma e melhoramento genético. Brasília, DF: Embrapa Cerrados, 2005. p. 187-210.

FERREIRA, G. Propagação do maracujazeiro. Informe Agropecuário, Belo Horizonte, MG. 2000. v. 21, n. 206, p. 18-24.

FISCHER, I.H.; KIMATI, H. \& REZENDE, J.A.M. Doenças do Maracujazeiro. In: KIMATI, H.; AMORIM, L.; REZENDE, J.A.M.; BERGAMIN FILHO, A.; CAMARGO, L.E.A. (Ed.) Manual de Fitopatologia. v2. 4.ed. São Paulo: Agronômica Ceresp. 467-474. 2005.

GONÇALVES, I.M.P. Produtividade e reação de progênies de maracujazeiro azedo a doenças em campo e casa de vegetação. Brasília: Faculdade de Agronomia e Medicina Veterinária, Universidade de Brasília-Brasília, 2011. p.121. Dissertação de Mestrado.

GUERRA, N.B; LIVERA, A.V.S. Correlação entre o perfil sensorial e determinações físicas e químicas do abacaxi cv. pérola. Cruz das Almas: Revista Brasileira de Fruticultura, v.21, n.1, p.32-35, Abril. 1999.

JUNQUEIRA, N.T.V.; ANJOS, J.R.N.; SILVA, A.P.O.; CHAVES, R.C.; GOMES, A.C. Reação às doenças e produtividade de onze cultivares de maracujá-azedo cultivadas sem agrotóxicos. Pesquisa Agropecuária Brasileira. v. 38, n. 8, p. 1005-1010. 2003

KASSANIS, B. Effects of changing temperature on plant virus disease. Advances in Virus Research, 1957. v. 4, p. 221-241.

KITAJIMA, E.W.; CHAGAS, C.M. \& CRESTANI, O.A. Enfermidades de etiologia viral e associadas a organismos do tipo micoplasma em maracujazeiro no Brasil. Fitopatologia Brasileira. v.11, p.409-432.1986.

LEÃO, R. M. K. Reação de progênies de maracujá-azedo ao vírus do endurecimento do fruto ("Passionfruit woodiness virus" - PWV) e à bactéria Xanthomonas campestris pv. passiflorae. Brasília: Universidade de Brasília,2001. p.89. Dissertação de mestrado. 
LIMA. A.A; CUNHA, M.A.P. Práticas Culturais. In: LIMA, A.A e CUNHA, M.A.P. Maracujá: produção e qualidade na passiultura. Cruz das Almas: Embrapa Mandioca e Fruticultura, 2004. p. 169-178.

MALAVOLTA JR.V.A. Bacteriose do maracujazeiro. In: SIMPÓSIO BRASILEIRO SOBRE A CULTURA DO MARACUJÁ1, 5.,1998. Jaboticabal,Anais... Jaboticabal.1998. p.217-229. MELO, K.T. Comportamento de seis cultivares de maracujazeiro azedo (Passiflora edulis Sims e Passiflora edulis Sims f. flavicarpa Deg.) em Vargem Bonita no Distrito Federal. Brasília: Faculdade de Agronomia e Medicina Veterinária, Universidade de Brasília,1999, 99f. Dissertação (Mestrado em Ciências Agrárias).

MELLO, R.M. Desempenho agronômico e reação a virose do endurecimento dos Frutos em genótipos de maracujazeiro azedo cultivados no Distrito Federal. Brasília: Faculdade de Agronomia e Medicina Veterinária, Universidade de Brasília, 2009. p.134. Dissertação de Mestrado.

MIRANDA, H.A. Incidência e severidade de Xanthomonas axonopodis pv. passiflorae, Colletotrichum gloeosporioides, Septoria passiflorae, Cladosporium herbarum e Passion Woodiness fruit virus em genótipos de maracujazeiro azedo cultivados no Distrito Federal. Brasília: Faculdade de Agronomia e Medicina Veterinária, Universidade de Brasília, 2004. 87f. Dissertação (Mestrado em Ciências Agrárias)

OLIVEIRA, J. C. Melhoramento genético de Passiflora edulis f.flavicarpa Deg. visando aumento de produtividade. Jaboticabal: FCAV-UNESP, 1980. 133p. (Tese de LivreDocência).

. FERREIRA, F. R. Melhoramento genético do maracujazeiro. In: SÃO JOSÉ, A. R.; FERREIRA, F. R.; VAZ, R. L. A cultura do maracujá no Brasil. Jaboticabal: FUNEP, p.221-239. 1991.

PIO-RIBEIRO, G. \& MARIANO, R.L.R.D. Doenças do maracujazeiro (Passiflora spp.). In: Manual de fitopatologia: doenças das plantas cultivadas. 3.ed. São Paulo: Editora Agronômica Ceres, 1997.v. 2, p. 525-534.

PIO VIANA, A.; PEREIRA, T.N.S.; PEREIRA, M.G.; SOUZA, M.M.; MALDONADO, F.; AMARAL JÚNIOR, A.T. Diversidade em maracujazeiro amarelo (Passiflora edulis f. flavicarpa) e Passiflora spp. por marcadores RAPD. Revista Brasileira de Fruticultura, Jaboticabal, v.25, p.489-493. 2003. 
REZENDE, J.A.M. Doenças de vírus e micoplasma do maracujazeiro no Brasil. In: SÃO JOSÉ, A.R. (Ed.) Maracujá: produção e mercado. Vitória da Conquista: UESB p.116-125. 1994.

SANTOS FILHO, H.P.; SANTOS, C.C.F. Maracujá: fitossanidade. Brasília: Embrapa Informação Tecnológica, P. 12-21. (Embrapa Informação Tecnológica. Série Frutas do Brasil, 32). 2003.

JUNQUEIRA, N.T. Maracujá: Fitossanidade. Brasília: Embrapa Informação Tecnológica, 86p. (Série Frutas do Brasil, 32). 2003.

SEIXAS, L.F.Z. Comportamento de espécies e híbridos interespecíficos de maracujazeiro quando inoculados com Xanthomonas campestris pv. passiflorae (Per.) Dye. 1989. Jabuticabal: Universidade de São Paulo, 1989. 193f. Monografia (Trabalho de Graduação).

SOUSA, M.A.F. Avaliação da produtividade, incidência, e severidade de doenças em frutos de 17 genótipos de maracujazeiro amarelo, cultivados no Distrito Federal. 2005. Brasília: Faculdade de Agronomia e Medicina Veterinária, Universidade de Brasília, 2005.120f. Dissertação (Mestrado em Ciências Agrárias) .

. Produtividade e reação de progênies de maracujazeiro azedo a doenças em campo e casa de vegetação. Brasília: Universidade de Brasília, 2009. 248p. Tese (Doutorado em Fitopatologia).

SOUZA, J.S.I.; MELETTI, L.M.M. Maracujá: espécies, variedades, cultivo. Piracicaba: FEALQ, 179p. 1997.

TOCCHINI, R.P.; NISIDA, A.L.A.C.; HASHIZUME, T.; MEDINA, J.C.; TURATTI, J.M. Processamento: produtos, caracterização e utilização. In: Maracujá: cultura, matériaprima, processamento e aspectos econômicos. $2^{\text {a }}$ ed. rev. e ampl. Campinas: ITAL, p. 161195. (Série Frutas Tropicais, 9). 1994.

VIANA, C.A.S. Resistência de progênies de maracujá-azedo à bacteriose (Xanthomonas axonopodis pv. passiflorae) e à virose do endurecimento do fruto (Cowpea aphid-borne mosaic virus). Brasília: Universidade de Brasília, 2007. 210f. Dissertação (Mestrado em Fitopatologia).

VIEIRA, M.L.C.; OLIVEIRA, C.A.; MAYEDA, L.Y.; DORNELAS, M.C.; FUNGARO, M.H.P. Estudo do cariótipo e da variabilidade genética detectada por RAPD em espécies de 
maracujazeiro (Passiflora L.). Brazilian Journal of Genetics, Ribeirão Preto, v.20, n.3, p. 88, Suplemento. 1997. 
CAPITULO 6

CARACTERIZAÇÃO MOLECULAR DE PROGÊNIES DE MARACUJAZEIROAZEDO COM DIFERENTES NÍVEIS DE PRODUTIVIDADE E RESISTÊNCIA A DOENÇAS 


\section{RESUMO}

A produtividade da cultura do maracujá no Brasil é considerada baixa, sendo que o cultivo de variedades inadequadas é um dos fatores que influenciam essa característica. Existe uma carência de materiais genéticos com alta produtividade, qualidade de frutos e resistência a fitopatógenos, em razão, principalmente, da falta de trabalhos de pesquisa nas diversas áreas do conhecimento e especialmente com melhoramento genético do maracujazeiro. Nesse trabalho, objetivou-se caracterizar e quantificar a variabilidade genética de dezoito progênies de maracujazeiro-azedo com diferentes níveis de produtividade e resistência a doenças, utilizando marcadores moleculares RAPD. Foram usados dez iniciadores decâmeros para a obtenção dos marcadores RAPD, que foram convertidos em uma matriz de dados binários, a partir da qual foram estimadas as dissimilaridades genéticas entre os diferentes acessos e realizadas análises de agrupamento. Foram obtidos cinquenta e oito marcadores RAPD, dos quais trinta e sete $(63,80 \%)$ foram polimórficos. As distâncias genéticas variaram de 0,040 a 0,354, entre as progênies. O iniciador OPF01 apresentou maior número de bandas polimórficas e também bandas monomórficas. Já o iniciador OPD04 foi aquele que deteve igual quantidade de bandas monomórficas e polimórficas. A análise dos gráficos de dispersão mostrou uma baixa tendência de agrupamento entre as progênies nas diferentes avaliações (produtividade, septoriose, antracnose, verrugose, bacteriose e virose), mostrando que existe alta variabilidade genética entre as progênies estudadas.

Palavras-chave: passiflora edulis, melhoramento, variabilidade genética 


\begin{abstract}
The Brazil is in an outstanding position in the cultivation of world fruit crops. Passion fruit is a culture that contributes to this situation, with Brazil a major producer of this fruit. However, the passion fruit crop yield is still considered low, and the cultivation of unsuitable varieties is one of the factors that influence this characteristic. In this sense, breeding work has been developed with the purpose of obtaining genetic materials with high productivity, fruit quality and disease resistance. In this sense this study aimed to characterize and quantify the genetic variability of 18 progenies of sour passion fruit with different levels of productivity and disease resistance, using RAPD molecular markers. 10 decamer primers were used to obtain the molecular markers, which were converted into a matrix of binary data, from which were estimate the genetic dissimilarities between different access and cluster analysis were performed. 58 molecular markers were obtained, of which 37 (63.80\%) were polymorphic. The genetic distances ranged from 0.040 to 0.354 , among the progenies. The initiator OPF01 presented the greatiest number of polymorphic and monomorphic bands. OPD04 initiator was the one who stopped equal amount of monomorphic and polymorphic bands. The analysis of scatter plots showed a low trend of grouping the progenies in different ratings (yield, resistance to Septoria, anthracnose, scab, blight and virus), showing that there is a high genetic variability among progenies.
\end{abstract}

Keywords: passiflora edulis, breeding, genetic variability 


\section{1 - INTRODUÇÃO}

O Brasil é o maior produtor e consumidor mundial de maracujá, o qual é cultivado por pequenos e médios agricultores com produtividades médias em torno de 14 ton/ha/ano. Esta produtividade está bem abaixo daquelas obtidas por variedades geneticamente melhoradas (FALEIRO et al., 2008).

O desenvolvimento de cultivares com alta produtividade, qualidade de frutas e resistência a fitopatógenos é uma importante demanda para a pesquisa (FALEIRO et al., 2006) especialmente nas áreas de melhoramento genético do maracujazeiro. Estudos de melhoramento genético normalmente visam ao desenvolvimento de materiais superiores, principalmente com relação a caracteres de interesse agronômico e tendem a utilizar a hibridação intraespecífica para a transferência de genes de interesse (BRUCKNER, 1997).

O Brasil é um dos mais importantes centros de diversidade do maracujá, pois muitas espécies silvestres de Passiflora são nativas, notadamente, no Centro-Norte do país (FERREIRA, 2005), sendo importantes fontes de genes úteis para o melhoramento genético. Estima-se que mais de duzentas espécies de Passiflora sejam nativas do Brasil (OLIVEIRA et al., 1988). Além desse número expressivo de espécies, deve-se enfatizar que, em geral, existe material ainda não descrito que provavelmente constitua espécies novas (FERREIRA, 1994). Essa cultura apresenta ampla variabilidade genética a ser conhecida, caracterizada, protegida, conservada e convenientemente utilizada comercialmente ou em programas de melhoramento genético (FALEIRO et al., 2005).

Para explorar o potencial dessa cultura, testes de compatibilidade genética são realizados visando subsidiar a escolha de materiais a serem utilizados nos programas de melhoramento genético.

No entanto, fatores como o ambiente são limitantes no estudo de diversidade genética em Passiflora spp. Nesse sentido, a utilização de marcadores moleculares é uma ferramenta valiosa, por permitir um rápido, preciso e acurado estudo da variabilidade existente, detectando as variações diretamente no DNA.

Segundo JUNQUEIRA (2008), os marcadores RAPD são excelentes ferramentas para serem utilizadas em programas de melhoramento, pois permitem verificar a ocorrência da fecundação cruzada no gênero Passiflora e constatar a existência de compatibilidade genética entre espécies desse gênero. Além disso, tem grande importância na realização da seleção de genótipos que sejam compatíveis e superiores, o que pode permitir a produção de híbridos. 
Os marcadores RAPD foram utilizados em alguns trabalhos e utilizados na caracterização de diversidade genética no gênero Passiflora (BELLON et al., 2007; BELLON et al, 2005; FALEIRO et al., 2005b; VIANA et al., 2003; CASSIANO et al., 1998; ANGEL et al., 1998; VIEIRA et al., 1997).

Cada vez mais, a utilização de marcadores moleculares tem se tornado viável pela evolução de novas técnicas, redução dos custos de equipamentos, de reagentes e rapidez na obtenção de resultados. O uso de marcadores moleculares, por apresentar as características de estabilidade e neutralidade, é uma importante ferramenta para a caracterização molecular e o estudo da variabilidade genética (FERREIRA \& GRATTAPAGLIA, 1996). O Random Amplification of Polymorphic DNA (RAPD) tem se mostrado eficiente na identificação e na quantificação da variabilidade genética em diversos grupos de plantas, motivo pelo qual vem sendo usado como ferramenta auxiliar em programas de caracterização e uso de recursos genéticos e programas de melhoramento (FALEIRO, 2007; FERREIRA et al., 2007).

Devido à grande quantidade de hibridações realizadas nos trabalhos de pesquisa, entender a variabilidade genética existente no grupo de progênies utilizadas é de grande importância para a continuidade dos trabalhos de seleção e melhoramento genético do maracujá.

Nesse contexto, objetivou-se neste trabalho caracterizar e quantificar a variabilidade genética de dezoito progênies de maracujazeiro-azedo, desenvolvidas a partir de trabalhos de pesquisa realizados pela Universidade de Brasília - UnB e Embrapa Cerrados, utilizando marcadores moleculares RAPD, como subsídio para suas utilizações no melhoramento genético.

\section{2 - MATERIAL E MÉTODOS}

A partir de trabalhos de pesquisa desenvolvidos pela Universidade de Brasília - UnB e Embrapa Cerrados foram desenvolvidas as seguintes progênies originárias de hibridações intra-específicas e interespecíficas e também de materiais oriundos de seleção massal feita em pomares produtivos da região sudeste do Brasil (Tabela 47). 
Tabela 47 - Nome e origem das progênies analisadas no trabalho

\begin{tabular}{|c|c|c|}
\hline $\mathbf{N}^{\mathbf{o}}$ & $\begin{array}{l}\text { NOME DO } \\
\text { MATERIAL }\end{array}$ & ORIGEM \\
\hline 1 & MAR20\#34 P1.7 & $\begin{array}{c}\text { Seleção massal de nove genótipos superiores, sendo eles: } \\
\text { Maguary Mesa 1, Maguary Mesa 2, Havaiano, MSC (Marília } \\
\text { Seleção Cerrado), Seleção DF, EC-2-0, F1 (Marília x Roxo } \\
\text { Australiano), F1 (Roxo Fiji x Marília) e RC1 [F1 (Marília x Roxo } \\
\text { Australiano) x Marília (pai recorrente)]. }\end{array}$ \\
\hline 2 & MAR20\#44 & $\begin{array}{c}\text { Obtidos por seleção massal de plantios comerciais contendo nove } \\
\text { materiais superiores, considerando os aspectos de produtividade, } \\
\text { qualidade de frutos e resistência aos patógenos, trazidos do } \\
\text { município de Araguari. }\end{array}$ \\
\hline 3 & MAR20\#15 & $\begin{array}{c}\text { Obtidos através de sementes coletadas do campo experimental da } \\
\text { Fazenda Água Limpa - UnB - } 2012\end{array}$ \\
\hline 4 & ECL 7 & Derivado da cultivar Marília. \\
\hline 5 & EC3-0 & (Marilia X Rubi gigante) X Marilia. \\
\hline 6 & MAR20\#39 & $\begin{array}{c}\text { Seleção massal de plantios comerciais contendo nove materiais } \\
\text { superiores. }\end{array}$ \\
\hline 7 & MAR20\#2005 Pl.2 & $\begin{array}{l}\text { Seleção massal de nove genótipos superiores, sendo eles: Maguary } \\
\text { Mesa 1, Maguary Mesa 2, Havaiano, MSC (Marília Seleção } \\
\text { Cerrado), Seleção DF, EC-2-0, F1 (Marília x Roxo Australiano), F1 } \\
\text { (Roxo Fiji x Marília) e RC1 [F1 (Marília x Roxo Australiano) x } \\
\text { Marília (pai recorrente)]. }\end{array}$ \\
\hline 8 & Rosa Int. Pl.1 & Seleção recorrente baseada em família de $1 / 2$ irmãos. \\
\hline 9 & MSCA & Marília seleção cerrado. \\
\hline 10 & MAR20\#19 & $\begin{array}{c}\text { Obtidos por seleção massal de plantios comerciais contendo nove } \\
\text { materiais superiores, considerando os aspectos de produtividade, } \\
\text { qualidade de frutos e resistência aos patógenos, trazidos do } \\
\text { município de Araguari. }\end{array}$ \\
\hline 11 & MAR20\#2005 P1.1 & $\begin{array}{l}\text { Seleção massal de nove genótipos superiores, sendo eles: Maguary } \\
\text { Mesa 1, Maguary Mesa 2, Havaiano, MSC (Marília Seleção } \\
\text { Cerrado), Seleção DF, EC-2-0, F1 (Marília x Roxo Australiano), F1 } \\
\text { (Roxo Fiji x Marília) e RC1 [F1 (Marília x Roxo Australiano) x } \\
\text { Marília (pai recorrente)] }\end{array}$ \\
\hline 12 & MAR20\#41 & $\begin{array}{c}\text { Obtidos por seleção massal de plantios comerciais contendo nove } \\
\text { materiais superiores, considerando os aspectos de produtividade, } \\
\text { qualidade de frutos e resistência aos patógenos, trazidos do } \\
\text { município de Araguari. }\end{array}$ \\
\hline 13 & MAR20\#46 Pl.1 & $\begin{array}{c}\text { Obtidos por seleção massal de plantios comerciais contendo nove } \\
\text { materiais superiores, considerando os aspectos de produtividade, } \\
\text { qualidade de frutos e resistência aos patógenos, trazidos do } \\
\text { município de Araguari. }\end{array}$ \\
\hline 14 & AP01 & Seleção recorrente baseada em família de $1 / 2$ irmãos. \\
\hline 15 & AR02 & $\begin{array}{c}\text { Seleção individual de plantas resistentes à antracnose de uma } \\
\text { população de Roxo Australiano. }\end{array}$ \\
\hline 16 & 20\#34 F2 & $\begin{array}{l}\text { Seleção massal de nove genótipos superiores, sendo eles: Maguary } \\
\text { Mesa 1, Maguary Mesa 2, Havaiano, MSC (Marília Seleção } \\
\text { Cerrado), Seleção DF, EC-2-0, F1 (Marília x Roxo Australiano), F1 }\end{array}$ \\
\hline
\end{tabular}




\begin{tabular}{|c|c|c|}
\hline $\mathbf{N}^{\mathbf{o}}$ & $\begin{array}{c}\text { NOME DO } \\
\text { MATERIAL }\end{array}$ & ORIGEM \\
\hline & & $\begin{array}{l}\text { (Roxo Fiji x Marília) e RC1 [F1 (Marília x Roxo Australiano) x } \\
\text { Marília (pai recorrente)]. }\end{array}$ \\
\hline 17 & MAR20\#49 & $\begin{array}{l}\text { Seleção massal de plantios comerciais contendo nove materiais } \\
\text { superiores. }\end{array}$ \\
\hline 18 & MAR20\#46 & $\begin{array}{c}\text { Obtidos por seleção massal de plantios comerciais contendo nove } \\
\text { materiais superiores, considerando os aspectos de produtividade, } \\
\text { qualidade de frutos e resistência aos patógenos, trazidos do } \\
\text { município de Araguari. }\end{array}$ \\
\hline
\end{tabular}

O trabalho foi realizado no Laboratório de Genética e Biologia Molecular da Embrapa Cerrados. Foram utilizadas dezoito progênies de maracujazeiro-azedo selecionadas com base nas avaliações agronômicas de produtividade e resistência ou tolerância às doenças, após quatro avaliações de casa de vegetação e trinta e duas colheitas em quatro diferentes época, em campo, sem o uso de defensivos agrícolas. As progênies com maior distância genética serão utilizadas para cruzamento e novas avaliações em trabalhos futuros.

Folhas de cada uma dessas progênies foram coletadas e o DNA genômico extraído utilizando o método do CTAB, com modificações (FALEIRO et al., 2003). Amostras de DNA foram amplificadas pela técnica de RAPD. As reações de amplificação foram feitas em um volume total de $13 \mu \mathrm{l}$, contendo Tris- $\mathrm{HCl} 10 \mathrm{~mm}$ (ph 8,3), $\mathrm{KCl} 50 \mathrm{~mm}, \mathrm{MgCl} 23 \mathrm{~mm}, 100$ $\mu \mathrm{m}$ de cada um dos desoxiribonucleotídios (dATP, dTTP, dGTP e dCTP), 0,4 $\mu \mathrm{m}$ de um iniciador (Operon Technologies Inc., Alameda, CA, EUA), uma unidade da enzima Taq polimerase e, aproximadamente, $15 \mathrm{ng}$ de DNA. Para obtenção dos marcadores RAPD foram utilizados dez iniciadores ou primers decâmeros: OPD (04, 07, 08, 10), OPE (16), OPF (01 e 17), OPG (05), OPH (04 e 12).

As amplificações foram efetuadas em termociclador programado para quarenta ciclos, cada um composto formado pela seguinte sequência: $15 \mathrm{~s}$ a $94^{\circ} \mathrm{C}, 30 \mathrm{~s}$ a $35^{\circ} \mathrm{C}$ e $90 \mathrm{~s}$ a $72^{\circ}$ C.Concluídos os 40 ciclos, foi feita uma etapa de extensão final de seis minutos a $72^{\circ} \mathrm{C}$, e finalmente, a temperatura foi reduzida para $4^{\circ}$ C. Após a amplificação, foram icionados, a cada amostra, $3 \mu 1$ de uma mistura de azul de bromofenol (0,25\%) e glicerol $(60 \%)$ em água. Essas amostras foram aplicadas em gel de agarose (1,2\%), corado com brometo de etídio, submerso em tampão TBE (Tris-Borato 90 mm, EDTA $1 \mathrm{~mm}$ ). A separação eletroforética foi de, aproximadamente, quatro horas, a noventa volts. Ao término da corrida, os geis foram fotografados sob luz ultravioleta. 
Os marcadores RAPD gerados foram convertidos em uma matriz de dados binários, a partir da qual foram estimadas as distâncias genéticas entre as diferentes progênies, com base no complemento do coeficiente de similaridade de NEI \& LI, utilizando-se o Programa Genes (CRUZ, 2007). A matriz de distâncias genéticas foi utilizada para realizar as análises de agrupamento com o auxílio do Programa Statistica (STATSOFT INC, 1999), utilizando como critério de agrupamento o método do UPGMA. Ainda com base na matriz de distâncias genéticas, foi realizada a dispersão gráfica baseada em escalas multidimensionais usando o método das coordenadas principais, com auxílio do Programa SAS e Statistica (STATSOFTINC, 1999).

\section{3 - RESULTADOS E DISCUSSÃO}

A análise das dezoito progênies de maracujazeiro-azedo, por meio do uso de dez iniciadores, gerou um total de cinquenta e oito marcadores RAPD, dos quais trinta e sete $(63,80 \%)$ foram polimórficos perfazendo uma média de 5,8 bandas por primer. O iniciador OPF01 apresentou maior número de bandas polimórficas e também bandas monomórficas. Já o iniciador OPD04 foi aquele que deteve igual quantidade de bandas monomórficas e polimórficas (Tabela 48).

A maior percentagem de marcadores polimórficos demonstram a alta variabilidade genética entre as progênies. Esse comportamento pode ser explicado pela variabilidade genética existente em acessos comerciais, especialmente quando se comparam acessos de procedências diferentes JUNQUEIRA et al. (2005).

Segundo GANGA et al. (2004), um dos fatores que pode explicar a elevada diversidade genética existente no maracujazeiro é a alogamia, com presença de um sistema genético de autoincompatibilidade que favorece a polinização cruzada e, consequentemente, o fluxo gênico entre genótipos distintos. 
Tabela 48 - Iniciadores utilizados para obtenção dos marcadores RAPD e respectivos números de bandas polimórficas e monomórficas.

\begin{tabular}{|c|c|c|c|}
\hline INICIADOR & $\begin{array}{c}\text { SEQUENCIA } \\
\mathbf{5}^{\prime}-\mathbf{- 3}^{\prime}\end{array}$ & $\begin{array}{c}\mathbf{N}^{\mathbf{0}} \text { DE BANDAS } \\
\text { POLIMÓRFICAS }\end{array}$ & $\begin{array}{c}\mathbf{N}^{\mathbf{0}} \text { DE BANDAS } \\
\text { MONOMÓRFICAS }\end{array}$ \\
\hline OPD04 & TCTGGTGAGG & 3 & 3 \\
\hline OPD07 & TTGGCACGGG & 6 & 4 \\
\hline OPD08 & GTGTGCCCCA & 3 & 2 \\
\hline OPD10 & GGTCTACACC & 3 & 0 \\
\hline OPE16 & GGTGACTGTG & 4 & 2 \\
\hline OPF01 & ACGGATCCTG & 6 & 2 \\
\hline OPF17 & AACCCGGGAA & 5 & 2 \\
\hline OPG05 & CTGAGACGGA & 5 & 3 \\
\hline OPH04 & GGAAGTCGCC & 2 & 2 \\
\hline OPH12 & ACGCGCATGT & 3 & $\mathbf{2 1}$ \\
\hline TOTAL & & $\mathbf{3 7}$ & \\
\hline
\end{tabular}

Dissimilaridades genéticas variaram de 0,354 a 0,040 entre as progênies avaliadas de maracujazeiro. Essas distâncias genéticas caracterizam a expressiva diversidade existente entre as progênies estudadas, o que também foi verificado por VILELA (2013) que obteve distâncias genéticas entre trinta e dois acessos de maracujá variando de 0,08 a 0,39. Essas trinta e duas progênies foram subdivididas em pelo menos sete grupos de similaridade a uma distância genética relativa de 0,19. PIO VIANA (2003), estudando a diversidade genética entre genótipos comerciais de maracujazeiro-amarelo e entre espécies de passifloras nativas, observou a formação de três grandes grupos. No trabalho apresentado, verifica-se a subdivisão das dezoito progênies em pelo menos cinco grupos de similaridade (Figura 9). 
Tabela 49 - Matriz de dissimilaridade genética entre dezoito progênies de maracujáazedo, calculada com base no complemento do coeficiente de similaridade de NEI \& LI (1979), utilizando-se cinquenta e oito marcadores RAPD.

\begin{tabular}{|c|c|c|c|c|c|c|c|c|c|c|c|c|c|c|c|c|c|c|}
\hline & 1 & 2 & 3 & 4 & 5 & 6 & 7 & 8 & 9 & 10 & 11 & 12 & 13 & 14 & 15 & 16 & 17 & 18 \\
\hline \multirow{3}{*}{1} & 0,00 & & & & & & & & & & & & & & & & & \\
\hline & 0 & & & & & & & & & & & & & & & & & \\
\hline & 0,17 & 0,00 & & & & & & & & & & & & & & & & \\
\hline \multirow[t]{2}{*}{2} & 1 & 0 & & & & & & & & & & & & & & & & \\
\hline & 0,14 & 0,07 & 0,00 & & & & & & & & & & & & & & & \\
\hline \multirow[t]{2}{*}{3} & 7 & 7 & 0 & & & & & & & & & & & & & & & \\
\hline & 0,26 & 0,18 & 0,19 & 0,00 & & & & & & & & & & & & & & \\
\hline \multirow[t]{2}{*}{4} & 8 & 5 & 0 & 0 & & & & & & & & & & & & & & \\
\hline & 0,25 & 0,19 & 0,20 & 0,13 & 0,00 & & & & & & & & & & & & & \\
\hline \multirow[t]{2}{*}{5} & 4 & 5 & 5 & 2 & 0 & & & & & & & & & & & & & \\
\hline & 0,27 & 0,14 & 0,14 & 0,04 & 0,04 & 0,00 & & & & & & & & & & & & \\
\hline \multirow[t]{2}{*}{6} & 0 & 0 & 6 & 8 & 0 & 0 & & & & & & & & & & & & \\
\hline & 0,28 & 0,19 & 0,19 & 0,11 & 0,18 & 0,14 & 0,00 & & & & & & & & & & & \\
\hline \multirow[t]{2}{*}{7} & 8 & 0 & 5 & 9 & 9 & 6 & 0 & & & & & & & & & & & \\
\hline & 0,26 & 0,22 & 0,20 & 0,13 & 0,14 & 0,14 & 0,15 & 0,00 & & & & & & & & & & \\
\hline \multirow[t]{2}{*}{8} & 8 & 0 & 5 & 9 & 3 & 0 & 3 & 0 & & & & & & & & & & \\
\hline & 0,34 & 0,23 & 0,22 & 0,21 & 0,15 & 0,15 & 0,20 & 0,20 & 0,00 & & & & & & & & & \\
\hline 9 & 2 & 3 & 0 & 4 & 5 & 9 & 0 & 5 & 0 & & & & & & & & & \\
\hline 1 & 0,25 & 0,23 & 0,23 & 0,21 & 0,13 & 0,22 & 0,22 & 0,17 & 0,21 & 0,00 & & & & & & & & \\
\hline 0 & 4 & 7 & 3 & 1 & 0 & 5 & 5 & 9 & 5 & 0 & & & & & & & & \\
\hline 1 & 0,21 & 0,22 & 0,23 & 0,21 & 0,18 & 0,25 & 0,26 & 0,23 & 0,18 & 0,15 & 0,00 & & & & & & & \\
\hline 1 & 7 & 5 & 7 & 5 & 3 & 3 & 6 & 1 & 1 & 1 & 0 & & & & & & & \\
\hline 1 & 0,28 & 0,16 & 0,20 & 0,09 & 0,10 & 0,08 & 0,12 & 0,12 & 0,16 & 0,22 & 0,15 & 0,00 & & & & & & \\
\hline 2 & 9 & 9 & 0 & 3 & 8 & 7 & 4 & 6 & 5 & 1 & 0 & 0 & & & & & & \\
\hline 1 & 0,23 & 0,19 & 0,17 & 0,17 & 0,17 & 0,13 & 0,12 & 0,14 & 0,16 & 0,16 & 0,20 & 0,14 & 0,00 & & & & & \\
\hline 3 & 3 & 0 & 1 & 1 & 1 & 6 & 6 & 3 & 3 & 7 & 0 & 3 & 0 & & & & & \\
\hline 1 & 0,31 & 0,21 & 0,22 & 0,15 & 0,20 & 0,14 & 0,14 & 0,20 & 0,14 & 0,15 & 0,20 & 0,20 & 0,12 & 0,00 & & & & \\
\hline 4 & 5 & 4 & 9 & 7 & 0 & 9 & 0 & 5 & 9 & 1 & 5 & 4 & 9 & 0 & & & & \\
\hline 1 & 0,32 & 0,22 & 0,20 & 0,16 & 0,16 & 0,13 & 0,11 & 0,15 & 0,11 & 0,14 & 0,15 & 0,13 & 0,10 & 0,08 & 0,00 & & & \\
\hline 5 & 5 & 7 & 0 & 3 & 7 & 3 & 4 & 3 & 1 & 7 & 0 & 7 & 1 & 9 & 0 & & & \\
\hline 1 & 0,35 & 0,27 & 0,27 & 0,26 & 0,27 & 0,26 & 0,21 & 0,27 & 0,15 & 0,21 & 0,22 & 0,28 & 0,21 & 0,15 & 0,17 & 0,00 & & \\
\hline 6 & 3 & 5 & 3 & 6 & 3 & 8 & 0 & 3 & 7 & 7 & 7 & 7 & 5 & 7 & 2 & 0 & & \\
\hline 1 & 0,29 & 0,21 & 0,20 & 0,20 & 0,20 & 0,18 & 0,18 & 0,27 & 0,16 & 0,18 & 0,18 & 0,22 & 0,20 & 0,11 & 0,15 & 0,16 & 0,00 & \\
\hline 7 & 6 & 0 & 0 & 0 & 0 & 6 & 1 & 5 & 7 & 3 & 4 & 2 & 5 & 6 & 6 & 5 & 0 & \\
\hline 1 & 0,35 & 0,34 & 0,29 & 0,30 & 0,36 & 0,29 & 0,21 & 0,25 & 0,23 & 0,29 & 0,31 & 0,30 & 0,22 & 0,19 & 0,19 & 0,17 & 0,22 & 0,00 \\
\hline 8 & 4 & 2 & 7 & 7 & 5 & 1 & 5 & 3 & 1 & 2 & 4 & 1 & 1 & 0 & 0 & 8 & 1 & 0 \\
\hline
\end{tabular}




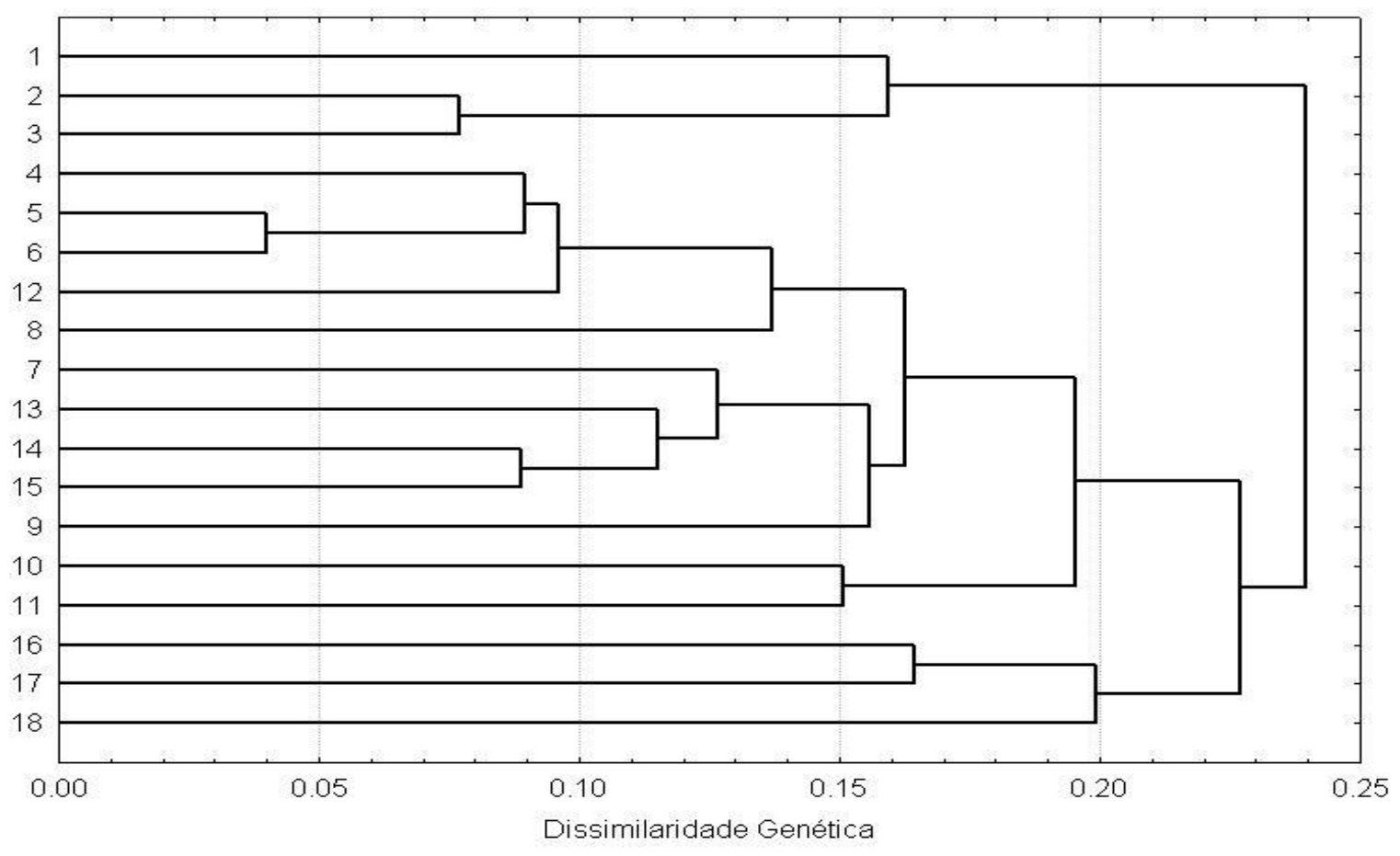

Figura 9 - Análise de agrupamento de dezoito progênies de maracujazeiro-azedo, com base na matriz de distâncias genéticas calculadas utilizando-se cinquenta e oito marcadores RAPD. $\mathrm{O}$ método do UPGMA foi utilizado como critério de agrupamento. Os números correspondem às progênies da Tabela 46.

O gráfico de dispersão (Figura 10) também construído com base na matriz de distâncias genéticas evidencia a separação dos acessos de maracujá-azedo. Os gráficos de dispersão apresentados mostram a tendência de agrupamento ou dispersão das progênies estudadas de acordo com a maior produtividade e resistência ou tolerância às doenças septoria, antracnose, verrugose, bacteriose e virose. É possível observar a dispersão e tendência de agrupamento de progênies nas diferentes avaliações, como descrito a seguir:

Produtividade (Figura 10a) - as progênies foram avaliadas quanto à produtividade e no gráfico de dispersão foi possível verificar pequena tendência de agrupamento das progênies com produtividade intermediária. Quanto à resistência à septoriose (Figura 10b), as progênies mais resistentes (cor verde) ocuparam diferentes posições no gráfico, indicando que tais progênies provavelmente apresentam diferentes origens genéticas e possivelmente diferentes genes de resistência, o que também foi verificado para a resistência à antracnose (Figura 10c). No caso da verrugose (Figura 10d) e da bacteriose (Figura 10e), houve uma tendência de agrupamento das progênies mais resistentes, evidenciando uma possível origem genética comum para os diferentes genes de resistência. No caso da virose (Figura 10f), essa tendência de agrupamento não foi verificada, indicando maior variabilidade genética das potenciais fontes de resistência.

Esses resultados mostram que as progênies estudadas se comportaram de maneira bem distintas quanto à produtividade e resistência a doenças, o que é reflexo da variabilidade 
genética dessas progênies, cujo estudo detalhado pode auxiliar os melhoristas na seleção das progênies mais promissoras para uso per se ou para uso como genitores em programas de melhoramento genético (Figura 10).

Da mesma forma, quando analisamos o gráfico de dispersão (Figura 10) podemos observar que a progênie AR02 apresentado quatro de seis níveis de produtividade/resistência sendo (mais produtivas/resistentes: verde) nas seguintes figuras (10c, d, e e f).

É importante dizer que a progênie de número 17 (MAR20\#49) não foi estudada nos outros capítulos e por isso o fenótipo para produtividade e resistência às doenças não foi caracterizado nos gráficos de dispersão. 
Figura 10 - Gráficos de dispersão de dezoito progênies de maracujazeiro-azedo com diferentes níveis de produtividade e resistência a doenças. As progênies foram classificadas em três grupos de acordo com o ranqueamento das progênies: verde (mais produtivas/resistentes), amarelo (produtividade/resistência intermediária) e vermelho (menos produtivas/resistentes).

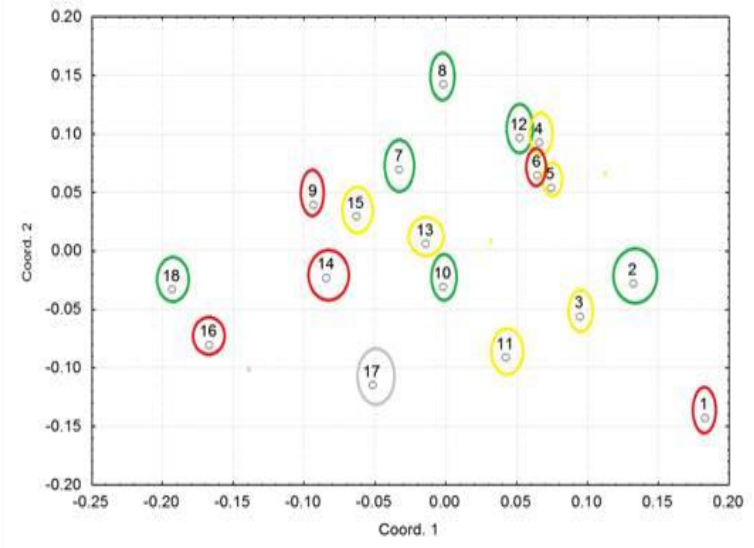

(a)

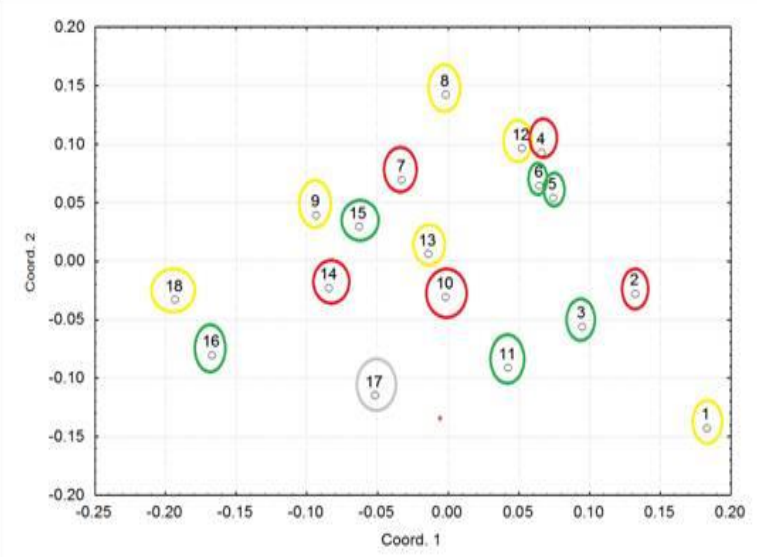

(c)

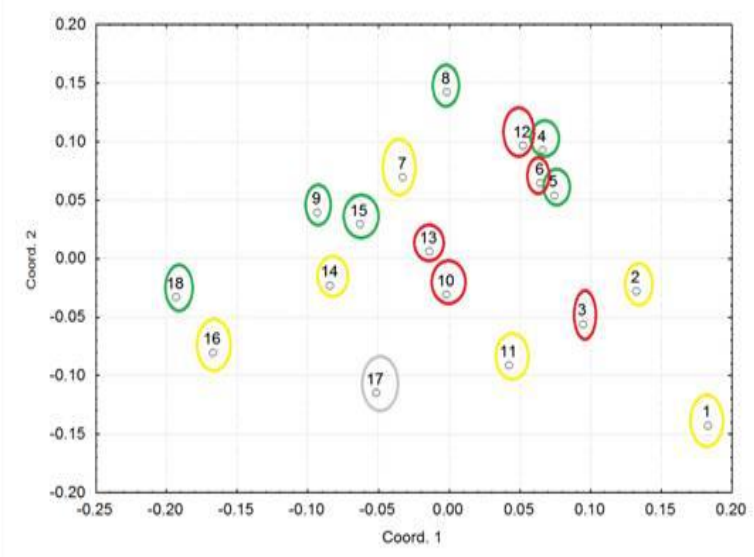

(e)

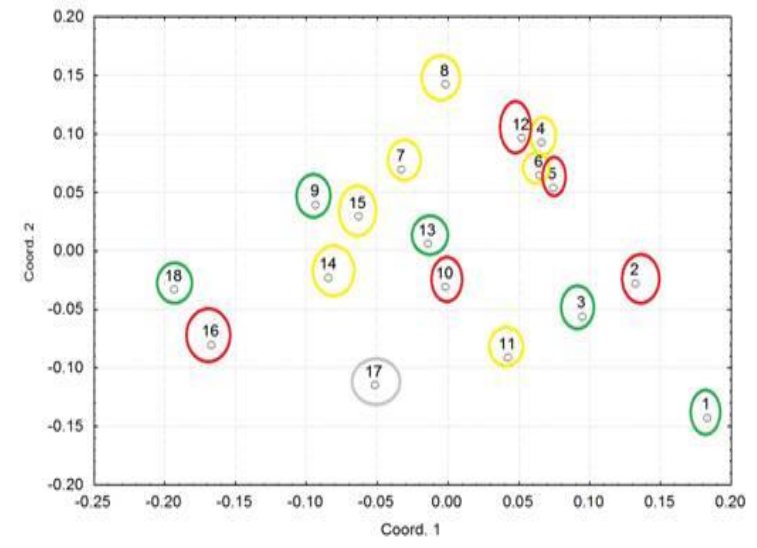

(b)

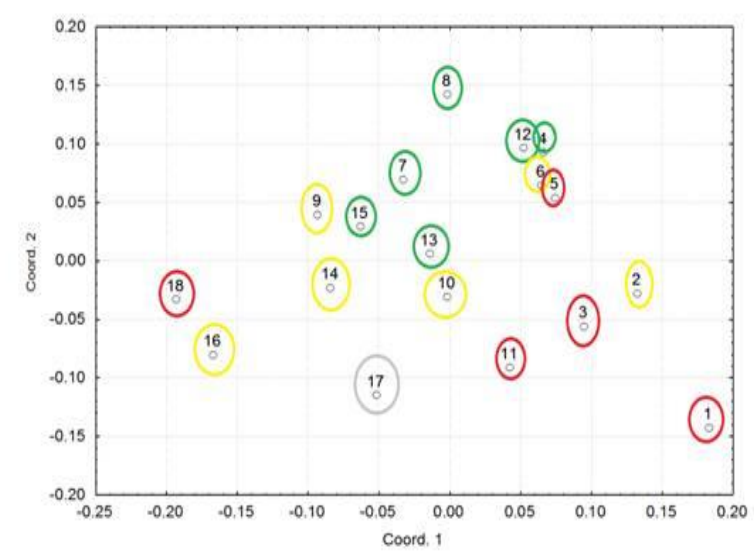

(d)

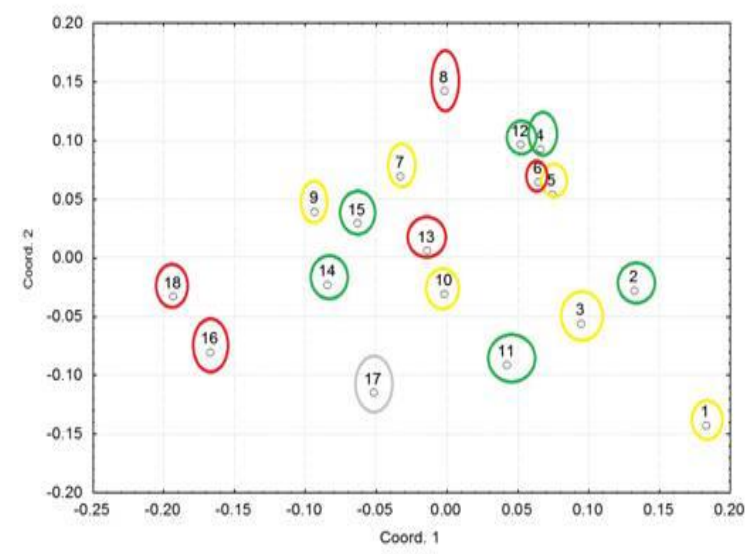

(f) 


\section{4 - CONCLUSÕES}

Foi verificada alta variabilidade genética das dezoito progênies de maracujazeiro analisadas com base em marcadores moleculares, evidenciando a variabilidade fenotípica dessas progênies quanto à produtivade e resistência às doenças.

Não houve tendência de agrupamento das progênies quanto à produtividade e resistência à septoriose, antracnose e virose, o que evidencia diferentes origens genéticas para os diferentes genes envolvidos nessas características. Para a verrugose e bacteriose, houve uma certa tendência de agrupamento das plantas mais produtivas/resistentes. 


\section{REFERÊNCIAS BIBLIOGRÁFICAS}

ANGEL, F. O.; FAJARDO, D.; GRUM, M.; TOHME, J.; LOBO, M.; Genetic variation analysis of the genus Passiflora L. using RAPD markers. Euphytica, Dordrecht, v.101: p. 341-347, 1998.

BELLON, G.; FALEIRO, F.G.; JUNQUEIRA, K.P.; PAULA, M.S.; BRAGA, M.F.; JUNQUEIRA, N.T.V.; PEIXOTO, J.R. Diversidade genética de acessos comerciais e silvestres de maracujazeiro doce com base nos marcadores RAPD. In: FALEIRO, F.G.; JUNQUEIRA, N.T.V.; BRAGA, M.F. (Ed.). Reunião Técnica De Pesquisas Em Maracujazeiro, 4., Planaltina, Distrito Federal: Embrapa Cerradosp.118-121, 2005.

commercial passion fruit (Passiflora edulis Sims.) accessions using RAPD markers. [Variabilidade genética de acessos silvestres e comerciais de Passiflora edulis Sims. com base em marcadores RAPD. Rev. Bras. Frutic. 29: 124-127. 2007.

BORGES, R.S., SCARANARI, C.; NICOLI, A.M. \& COELHO, R.R. Novas variedades: validação e transferência de tecnologia. In: FALEIRO, F.G., JUNQUEIRA, N.T.V. \& BRAGA, M.F. Maracujá: germoplasma e melhoramento genético. Planaltina, DF: Embrapa Cerrados. p.619-639. 2005.

BRUCKNER, C.H. Perspectivas do melhoramento do maracujazeiro. In: Manica, I. (Ed). Maracujá: temas selecionados. Porto Alegre, RS: Cinco Continentes. 70p. 1997.

CASSiAnO, A. P. A. A.; LEMOS, E.G.M.; OlIVEIRA, J.C., Avaliação de espécies de Passiflora através de marcadores moleculares RAPD. Genetics and Molecular Biology, v.21, n.3, p.214, Suplemento. 1998.

FALEIRO, F. Marcadores moleculares aplicados a programas de conservação e uso derecursos genéticos. Planaltina, DF: Embrapa Cerrados. 102 p. 2007.

FALEIRO, F.G.; JUNQUEIRA, N.T.V. \& BRAGA, M.F. Pesquisa e desenvolvimento do maracujá no Brasil. In: SILVA, A.G.; ALBUQUERQUE, A.C.S.; MANZANO, N.T.; SILVA, R.C. \& RUSSELL, N.C. (Eds.). Agricultura Tropical: Quatro Décadas de Inovações Tecnológicas, Institucionais e Políticas. 1 ed. Brasília: Embrapa, 2008. p. 411-416. Germoplasma e melhoramento genético do maracujazeiro Desafios da pesquisa. In: FALEIRO, F.G.; JUNQUEIRA, N.T.V.; BRAGA, M.F.(Ed.). 
Maracujá: germoplasma e melhoramento genético. Planaltina, Distrito Federal: Embrapa Cerrados. p.187-210. 2005a.

variedades comerciais de maracujazeiro azedo com base em marcadores RAPD. In: Reunião técnica de pesquisas em maracujazeiro, 4., Planaltina, DF: Embrapa Cerrados. p.105-109, $2005 b$

. FALEIRO, A.S.G.; CORDEIRO, M.C.R., KARIA, C.T. Metodologia para operacionalizar a extração de DNA de espécies nativas do cerrado. Planaltina: Embrapa Cerrados. 6p. (Comunicado Técnico, 92). 112. 2003.

FERREIRA, M. E.; MRETZSOHN, M. C.; BUSO, G. S. C. Fundamentos da caracterizaçãomolecular de germoplasma vegetal. In: NASS, L. L. (Ed.). Recursos genéticos vegetais. Brasília, DF: Embrapa Recursos Genéticos e Biotecnologia, p. 377-420. 2007.

FERREIRA, F. R. Recursos genéticos de Passiflora. In: FALEIRO, F. G.; JUNQUEIRA, N. T. V. \& BRAGA, M. F. (Ed.) Maracujá: germoplasma e melhoramento genético. Planaltina, DF: Embrapa Cerrados. p.41-51. 2005.

Germoplasma de Passiflora no Brasil. In: SÃO JOSE, A.R. (Ed.) Maracujá: produção e mercado. Vitória da Conquista: Universidade Estadual do Sudoeste da Bahia. p.24-26. 1994.

GANGA, R. M. D.; RUGGIERO, C.; LEMOS E.G.M.; GRILI, G. V. G.; GONÇALVES, M.M; CHAGAS, E. A. \& WICKERT, E. Diversidade genética em maracujazeiro amarelo utilizando marcadores moleculares AFLP. Revista Brasileira de Fruticultura, vol. 26, n. 3,494-498 p., dez. 2004.

IBGE. Banco de Dados agregados Maracujá. Disponível em: http://www.sidra.ibge.gov.br/bda/tabela/protabl.asp?c=106\&z=t \&o=11\&i=P. Acesso em: 11, janeiro, 2014.

INSTITUTO BRASILEIRO DE GEOGRARIA E ESTATÍSTICA. Maracujá: área plantada e quantidade produzida. Brasília: IBGE, 2011. (Produção Agrícola Municipal em 2009). Disponível em: http://www.sidra.ibge.gov.br/bda/tabela/protabl. Acesso em: fevereiro de 2013. 
JUNQUEIRA, K., P.; Confirmação de híbridos interespecíficos artificiais no gênero Passiflora por meio de marcadores RAPD. Revista Brasileira de Fruticultura. Jaboticabal, São Paulo, v. 30, n. 1, p. 191-196, Março. 2008.

FALEIRO, F.G.; RAMOS, J.D.; BELLON, G.; PAULA, M.S.; JUNQUEIRA, N.T.V.; BRAGA, M.F. Variabilidade genética de acessos de maracujá-suspiro (Passiflora nitida Kunth.) com base nos marcadores moleculares. In: Reunião técnica de pesquisas em maracujazeiro , 4 ., Planaltina, DF: Embrapa Cerrados, p.122-127.2005.

NEI, M.; LI, W.H. Mathematical model for studying genetic variation in terms of restriction endonucleases. Proceedings of the National Academy of Science, Washington, v.76, p. 5269$5273,1979$.

OLIVEIRA, J.C.; CARNIER, P.E. \& ASSIS, G.M. Preservação de germoplasma de maracujazeiros. In: ENCONTRO SOBRE RECURSOS GENÉTICOS, 1, Jaboticabal, 1988. Jaboticabal. Anais... Jaboticabal. 1988. 200 p.

VIEIRA, M.L.C.; OLIVEIRA, C.A.; MAYEDA, L.Y.; DORNELAS, M.C.; FUNGARO, M.H.P. Estudo do cariótipo e da variabilidade genética detectada por RAPD em espécies de maracujazeiro (Passiflora L.). Brazilian Journal of Genetics, Ribeirão Preto, v.20, n.3, p. 88, Suplemento. 1997. 


\section{ANEXOS}

\section{CROOUI}

\begin{tabular}{|c|c|c|c|c|c|c|c|c|c|c|c|c|c|c|}
\hline \\
\hline & 1 & 2 & 3 & 4 & 5 & 6 & 7 & 8 & 9 & 10 & 11 & 12 & Bordadura & Bordadura \\
\hline Bordadura & BL9L1 & MAR $20 \# 03$ & MAR20\#12 & BL2cx1 & MAR20\#03 & MAR20\#12 & MAR20\#34 & MAR20\#03 & MAR20\#40 & FB200 & BL5L8 & FB200 & FB 100 & $20 \# 49(3)$ \\
\hline 1 & Gig. Amar.2 & Rosa Claro 3 & PA 01 & MAR20\#12 & Rosa Int. & MAR20\#15 & Rosa Claro & MAR20\#15 & Rosa Int. & MAR20\#15 & PA 01 & Gig. Amar.2 & MAR20\#44 & FP01 BL2(1) \\
\hline 2 & MAR20\#44 & MAR20\#41 & $\mathrm{RC} 3$ & MAR20\#24 1 & MAR20\#121 & EC 3-0 & Rosa Int. 1 & Rosa Claro 2 & EC3-0 & Rubi. Gig. 2 & MAR $20 \# 39$ & MAR20\#41 & MAR20\#40 & $20 \# 23(1)$ \\
\hline 3 & FB200 & MAR20\#39 & MAR20\#24 2 & Rosa Int. & MAR20\#44 & MAR20\#21 & MAR20\#19 & MAR20\#34 & Rosa Int. & MAR20\#121 & AR 2 & ECL 7 & MAR20\#49 & AR 02(3) \\
\hline 4 & MAR20\#24 1 & MAR20\#46 1 & Rosa Int. 2 & MSCA 1 & MAR20\#41 & FB200 & Rubi. Gig. & MAR20\#46 & $20 \# 20054$ & 20\#2005 & MAR20\#44 & Rosa Int. 1 & MAR20\#242 & ECL7(1) \\
\hline 5 & MAR20\#10 & Rosa Claro 1 & $20 \# 20052$ & MAR20\#19 & ECRAM 3 & MSCA & $\mathrm{RC} 3$ & MAR20\#24 1 & ECRAM 3 & PES 9 & MAR20\#34 & Rubi Gig. 1 & MAR20\#34 & $20 \# 10(3)$ \\
\hline 6 & Rosa Int. 1 & MSCA & MAR20\#46 2 & Rosa Claro 1 & Gig. Amar. 1 & $20 \# 2005$ & MAR20\#41 & PES 9 & $20 \# 2005$ & EC 3-0 & FB200 & MAR20\#461 & MAR20\#12 & $20 \# 01(1)$ \\
\hline 7 & MAR20\#121 & $20 \# 20054$ & Rosa Claro 2 & AR 2 & MAR20\#10 & MAR20\#24 & MSCA & Gig. Amar.1 & $20 \# 34 \mathrm{~F} 2$ & Rosa Claro 1 & $20 \# 20051$ & $\mathrm{RC} 3$ & MAR20\#241 & $20 \# 292(3)$ \\
\hline 8 & EC 3-0 1 & ECRAM 3 & Rubi. Gig. 2 & MAR20\#34 & PES 9 & Rosa Claro & MAR20\#39 & Rubi Gig. 1 & MSCA & AP1 & Rosa Int. 2 & MAR20\#241 & MAR20\#292 & EC3-0(3) \\
\hline 9 & $\mathrm{MSCA} 1$ & $20 \# 20051$ & EC3-0 & Rosa Int. 1 & $20 \# 34 \mathrm{~F} 2$ & RC3 & MAR20\#121 & EC 3-0 & MSCA 1 & $20 \# 20054$ & MAR20\#19 & ECRAM 3 & MSCA 1 & 20\#09(1) \\
\hline 10 & Gig. Amar.1 & Rubi Gig. 1 & $20 \# 34 \mathrm{~F} 2$ & Rubi. Gig. & $\mathrm{MSCA}$ & MAR20\#46 1 & ECL 7 & MAR20\#24 & MAR20\#21 & EC3-0 & $20 \# 34 \mathrm{~F} 2$ & MSCA & $\mathrm{FB} 200(4)$ & EC3-0(1) \\
\hline 11 & MAR20\#21 & AR 2 & $\mathrm{AP1}$ & EC3-0 & $20 \# 20051$ & ECL 7 & $20 \# 2005$ & MAR20\#44 & Rosa Claro 1 & MAR20\#24 2 & MAR20\#21 & Rosa Claro 2 & $20 \# 41(4)$ & $20 \# 10(1)$ \\
\hline 12 & MAR20\#19 & ECL 7 & MSCA 2 & MAR20\#46 & MAR20\#39 & AP1 & AR 2 & FB200 & MAR20\#46 1 & $20 \# 20052$ & MSCA 1 & MAR20\#10 & $20 \# 46(4)$ & $\operatorname{Redond} 2(2)$ \\
\hline 13 & PES 9 & MAR20\#34 & $20 \# 20053$ & $20 \# 20054$ & Rubi Gig. 1 & $20 \# 2005$ & $\mathrm{AP} 1$ & $20 \# 20051$ & MAR20\#10 & Gig. Amar. 1 & MAR20\#46 2 & $\mathrm{MSCA} 2$ & AR 01(4) & $\operatorname{ECRAM}(1)$ \\
\hline 14 & Rosa Int. 3 & MAR20\#122 & MAR20\#15 & PA 01 & Gig. Amar. 2 & Rosa Claro & MAR20\#122 & Gig. Amar.2 & PA 01 & Rosa Int. 3 & Rosa Claro 3 & MAR20\#122 & C46BL2(3) & \\
\hline Bordadura & MAR20\#44 2 & BL7cx10 & BL8L1 & BL7cx10 & BL8L12 & BL7L1 & BL3cx1 & BL5L7 & BL2L10 & MAR20\#23 & $20 \# 2005$ & MAR20\#15 & B2L10(3) & \\
\hline \multirow{2}{*}{\multicolumn{3}{|c|}{ Planta 1}} & MAR20\#347 & & & MAR20\#44 1 & & & GAZ 1 & \multirow{6}{*}{\multicolumn{2}{|c|}{ 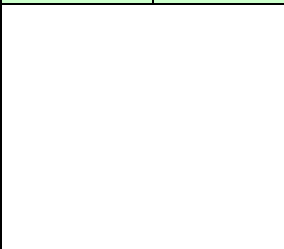 }} & Gig.Amar. 3 & \multirow{6}{*}{ 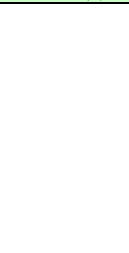 } & \\
\hline & & & MAR20\#44 1 & & & GAZ 1 & & & MAR20\#46 & & & ECRAM 2 & & \\
\hline Planta 2 & & & ECRAM 2 & & & MAR20\#46 & & & Gig.Amar. & & & MAR20\#44 1 & & \\
\hline Planta 3 & & & GAZ 1 & & & MAR20\#347 & & & MAR20\#44 1 & & & GAZ 1 & & \\
\hline Planta 4 & & & Gig.Amar.3 & & & Gig.Amar. & & & ECRAM & & & MAR20\#46 & & \\
\hline Planta 7 & & & MAR20\#463 & & & ECRAM & & & MAR20\#347 & & & MAR20\#347 & & \\
\hline
\end{tabular}

